$$
\begin{aligned}
& \text { Universidade de São Paulo } \\
& \text { Faculdade de Saúde Pública }
\end{aligned}
$$

\title{
Análise do processo participativo na gestão dos recursos hídricos no Estado de São Paulo: um estudo de caso do Comitê da Bacia Hidrográfica do Tietê - Jacaré
}

\author{
Mariza Guimarães Prota
}

Dissertação apresentada ao Programa de Pós-Graduação em Saúde Pública para obtenção do título de Mestre em Ciências

Área de Concentração: Saúde Ambiental

Orientador: Prof. Dr. Tadeu Fabrício Malheiros

São Paulo 


\title{
Análise do processo participativo na gestão dos recursos hídricos no Estado de São Paulo: um estudo de caso do Comitê da Bacia Hidrográfica do Tietê - Jacaré
}

\author{
Mariza Guimarães Prota
}

Dissertação apresentada ao Programa de Pós-Graduação em Saúde Pública para obtenção do título de Mestre em Ciências

Área de Concentração: Saúde Ambiental

Orientador: Prof. Dr. Tadeu Fabrício Malheiros

São Paulo 
É expressamente proibida a comercialização deste documento, tanto na sua forma impressa como eletrônica. Sua reprodução total ou parcial é permitida exclusivamente para fins acadêmicos e científicos, desde que na reprodução figure a identificação da autora, título, instituição e ano da dissertação. 
A meu pai Luiz José, por despertar em mim, desde criança, o interesse pela engenharia;

a minha mãe Célia (in memorian), por me mostrar que nunca é tarde para voltar a estudar; e a meu amigo Alexandre (in memorian), por me ajudar a descobrir os caminhos pelos comitês de bacia. 


\section{AGRADECIMENTOS}

Muitos colaboraram, direta ou indiretamente, para a realização deste trabalho. Meus mais sinceros agradecimentos a todos.

Ao meu orientador Tadeu Fabrício Malheiros, pela compreensão, incentivo e preciosa orientação;

Ao prof. Arlindo e aos colegas do Grupo de Pesquisa SIADES, pela acolhida carinhosa, pelas dicas valiosas e pelo apoio nesta caminhada;

Aos professores e colegas da Faculdade de Saúde Pública, da Escola Politécnica e da Faculdade de Arquitetura e Urbanismo, pelos conhecimentos transmitidos, pela troca de ideias e convivência gostosa;

Aos professores Mônica Porto, da EPUSP, e Nemésio Salvador, da UFSCar, pelas contribuições e oportunas sugestões para enriquecimento deste trabalho;

Aos funcionários da FSP, pelo auxílio atencioso sempre que necessário;

Aos profissionais da secretaria do Comitê Tietê - Jacaré, em especial ao eng $^{\circ}$ Braz Passalacqua, pelo recebimento carinhoso, fornecimento de informações e pela colaboração no contato junto aos membros do comitê;

Aos membros entrevistados do Comitê Tietê - Jacaré, pela troca de experiência e repasse de informações, imprescindíveis para este trabalho;

A Gabriel Magdalon, pela colaboração no levantamento de dados;

Aos meus anfitriões Leslie, Chico e Fábio Castro, em Jaú; Leila e Nino Arruda, em Bauru; e Natália Carnevale, em São Carlos, pela acolhida carinhosa durante as viagens pela bacia;

À UNESCO - IHE - Institute for Water Education, pela ajuda de custo nas viagens;

À SABESP, pela oportunidade de realizar esse curso;

Aos meus amigos, todos, da SABESP, pela paciência, pelo companheirismo e pelo importante apoio ao longo destes anos; e

Aos meus queridos César, Fernando e, especialmente, Donato, não só pelo apoio técnico imprescindível para a finalização deste trabalho, mas principalmente pelo carinho e paciência ao longo destes anos todos. 


\section{RESUMO}

PROTA, M. G. Análise do processo participativo na gestão dos recursos hídricos no Estado de São Paulo: um estudo de caso do Comitê da Bacia Hidrográfica do Tietê - Jacaré. [dissertação de mestrado]. São Paulo: Faculdade de Saúde Pública. 2011.

O modelo atual de gestão dos recursos hídricos no Brasil é descentralizado, participativo e integrado, e tem como unidade de planejamento a bacia hidrográfica. Baseia-se na atuação de comitês de bacia, sendo que cada comitê possui composição e regras de funcionamento próprias, regidas por seu estatuto. Os princípios básicos desta gestão foram ditados pela Constituição Brasileira de 1988 e detalhados pela Política Nacional de Recursos Hídricos, instituída por meio da Lei Federal no 9433/97. Porém, já em 1991, São Paulo promulgou sua Política Estadual de Recursos Hídricos, através da Lei Estadual № 7663/91, que também prevê a implementação de instrumentos de gestão. Atualmente, decorridos quase 20 anos da promulgação da lei estadual, críticas são feitas a este modelo de gestão. Esta pesquisa analisou o processo de participação nos comitês de bacia do Estado de São Paulo por meio de um estudo de caso no Comitê da Bacia Hidrográfica do Tietê - Jacaré, adotando como metodologia a aplicação de questionários aos seus membros da gestão 2009 - 2011. Os resultados encontrados, além de apontar para a necessidade de revisão do estatuto deste comitê, evidenciaram as distorções causadas pelas divergências entre a legislação estadual e a federal, principalmente quanto aos segmentos participantes e atores envolvidos. Mostraram também a necessidade de uma maior divulgação das questões de recursos hídricos nesta bacia e no Estado de São Paulo, como um todo.

Palavras-chave: gestão de recursos hídricos, comitê de bacia hidrográfica, processo participativo, bacia do Tietê - Jacaré 


\begin{abstract}
PROTA, M. G. Análise do processo participativo na gestão dos recursos hídricos no Estado de São Paulo: um estudo de caso do Comitê da Bacia Hidrográfica do Tietê - Jacaré. [Analise of the partipative process in the water resources management in the São Paulo State: a case study of Tiete - Jacare Watershed Commitee. [dissertação de mestrado]. São Paulo (BR): Faculdade de Saúde Pública. 2011.
\end{abstract}

The current model of water resources management in Brazil is decentralized, participative and integrated, and adopted the river basin as a planning unit. It's based on the performance of basin committees; each Committee has its own composition and rules of procedure, governed by its statute. The basic principles of this management have been established by the Brazilian Constitution of 1988 and detailed by the National Water Resources Policy, established by Federal Law o․ 9433/97. However, already in 1991, São Paulo State promulgated its Water Resources Policy, through State Law $n^{\circ} .7663 / 91$, which also provides for the implementation of management instruments. Nowadays, after almost 20 years of the enactment of State law, comments about this water resources management model have been made. This research examined the participatory process in basin committees of the São Paulo State through a case study in the Tiete - Jacare Basin Committee, based on the application of questionnaires to the Committee's members. The interviews' results have pointed that the Committee's statute need to be reviewed, and showed the differences between the Federal and the State legislations, mainly regarding the participating sectors and representatives involved. They also showed that a greater disclosure of water resource issues in this basin and in the State of São Paulo, as a whole, is necessary.

Keywords: water resources management, river basin Committee, participatory process, Tiete - Jacare Basin 


\section{ÍNDICE}

ÍNDICE.

LISTA DE SIGLAS ......................................................................... iii

LISTA DE FIGURAS........................................................................ vi

LISTA DE GRÁFICOS ........................................................................ vii

LISTA DE QUADROS …………………………………………....... viii

LISTA DE TABELAS................................................................... ix

1. INTRODUÇÃO E JUSTIFICATIVA DA PESQUISA …………………..... 1

2. OBJETIVOS DA PESQUISA ............................................................ 9

3. METODOLOGIA ....................................................................... 10

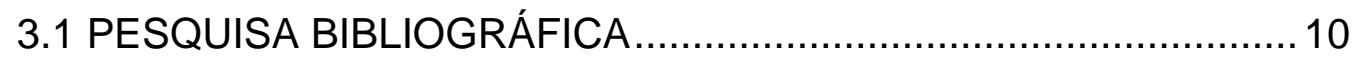

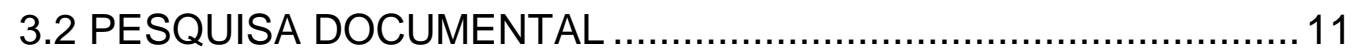

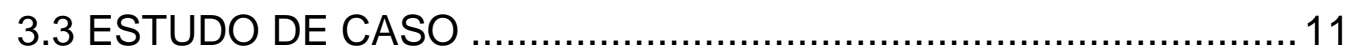

3.4 ANÁLISE DOS RESULTADOS ………...........................................21

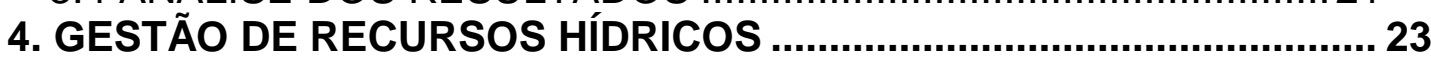

4.1 ASPECTOS CONCEITUAIS DA GESTÃO DE RECURSOS

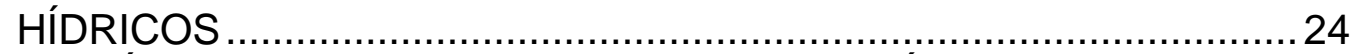

4.2 FÓRUNS GLOBAIS SOBRE RECURSOS HÍDRICOS..................27

4.3 PRINCIPAIS EXPERIÊNCIAS INTERNACIONAIS NA GESTÃO DE RECURSOS HÍDRICOS............................................................ 30

4.4 ASPECTOS SOBRE PARTICIPAÇÃO SOCIAL NA GESTÃO DE RECURSOS HÍDRICOS................................................................ 38

4.5 LIÇÕES DA EXPERIÊNCIA INTERNACIONAL AO MODELO

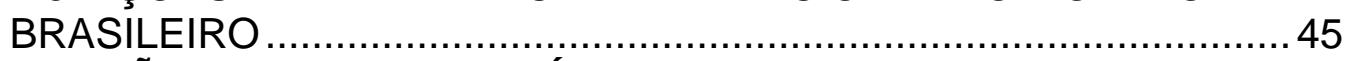

5. GESTÃO DE RECURSOS HÍDRICOS NO BRASIL.................................47

5.1 HISTÓRICO DA GESTÃO DE RECURSOS HÍDRICOS NO BRASIL

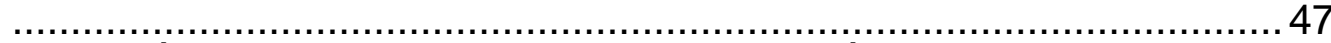

5.2 POLÍTICA NACIONAL DE RECURSOS HÍDRICOS .....................56

5.3 POLÍTICAS ESTADUAIS DE RECURSOS HÍDRICOS ..................65

5.4 POLÍTICA DE RECURSOS HÍDRICOS DO ESTADO DE SÃO

PAULO ….......................................................................... 68

5.5 SITUAÇÃO ATUAL DO SISTEMA DE GESTÃO DE RECURSOS

HÍDRICOS NO BRASIL ............................................................... 77

5.6 DESAFIOS DO ATUAL SISTEMA DE GESTÃO DE RECURSOS

HÍDRICOS DO BRASIL ............................................................. 93

6. CATEGORIAS PARA A ANÁLISE DO PROCESSO PARTICIPATIVO

NA GESTÃO DE RECURSOS HÍDRICOS.

7. ESTUDO DE CASO DO COMITÊ DA BACIA TIETÊ - JACARÉ 
7.1 DESCRIÇÃO DA BACIA HIDROGRÁFICA DO TIETÊ - JACARÉ 125

7.2 DESCRIÇÃO DO COMITÊ DA BACIA HIDROGRÁFICA DO TIETÊ

- JACARÉ 132

7.3 SITUAÇÃO ATUAL DO COMITÉ DA BACIA HIDROGRÁFICA DO

TIETÊ - JACARÉ 136

7.4 PROCESSO DE ESTABELECIMENTO DO PLANO DE BACIA .. 139

7.5 PROCESSO DE FORMULAÇÃO DOS CRITÉRIOS DA COBRANÇA PELO USO DOS RECURSOS HÍDRICOS

7.6 RESULTADOS OBTIDOS NOS QUESTIONÁRIOS....

7.7 ANÁLISE DOS RESULTADOS DO ESTUDO DE CASO 179

8. CONCLUSÕES

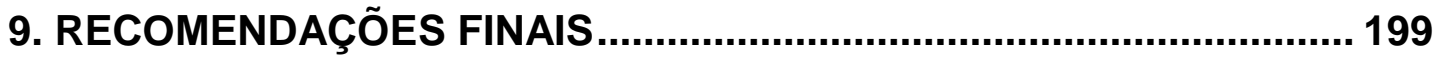

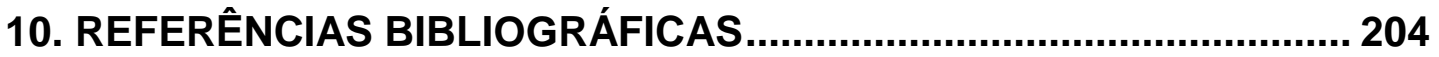

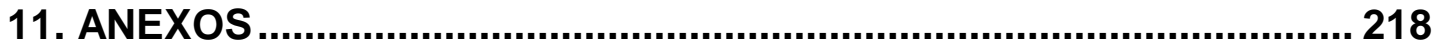

11.1 MENSAGEM ENVIADA AO SECRETÁRIO EXECUTIVO DO COMITÊ DA BACIA HIDROGRÁFICA DO TIETÊ - JACARÉ .............218 11.2 LISTA DOS MEMBROS DO COMITÊ DA BACIA HIDROGRÁFICA DO TIETÉ - JACARÉ DA GESTÃO 2009 - $2011 \ldots \ldots \ldots \ldots \ldots \ldots \ldots \ldots \ldots . . . .221$ 11.3 APRESENTAÇÃO DA PESQUISA AOS ENTREVISTADOS .....224 11.4 TERMO DE CONSENTIMENTO ...........................................22 11.5 QUESTIONÁRIO SOBRE GESTÃO DE RECURSOS HÍDRICOS 228

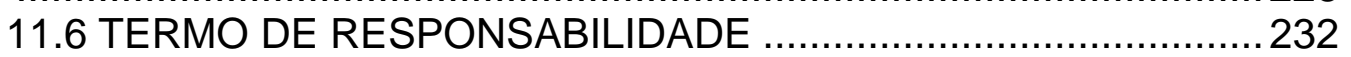

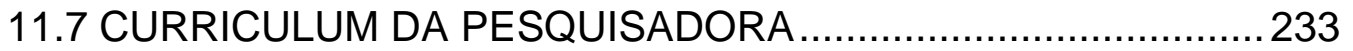

11.8 CURRICULUM DO ORIENTADOR ........................................... 11.9 APRESENTAÇÃO UTILIZADA PARA DEFESA DA DISSERTAÇÃO 235 


\section{LISTA DE SIGLAS}

\begin{tabular}{|c|c|}
\hline ABRH & - Associação Brasileira de Recursos Hídricos \\
\hline AGEVAP & - Agência da Bacia do Rio Paraíba do Sul \\
\hline ANA & - Agência Nacional de Águas \\
\hline ASSEMAE & $\begin{array}{l}\text { - Associação Nacional dos Serviços Municipais de } \\
\text { Saneamento }\end{array}$ \\
\hline $\mathrm{CBH}(\mathbf{s})$ & - Comitê(s) de Bacia Hidrográfica \\
\hline CBH PCJ & $\begin{array}{l}\text { - Comitê das Bacias Hidrográficas dos rios Piracicaba, } \\
\text { Capivari e Jundiaí }\end{array}$ \\
\hline CBH PJ & - Comitê das Bacias Hidrográficas do Piracicaba e Jaguari \\
\hline CBH PS & - Comitê da Bacia Hidrográfica do rio Paraíba do Sul \\
\hline CBH TJ & - Comitê da Bacia Hidrográfica do Tietê - Jacaré \\
\hline CEEIBH & $\begin{array}{l}\text { - Comitê Especial de Estudos Integrados de Bacias } \\
\text { Hidrográficas }\end{array}$ \\
\hline CEEIVAP & $\begin{array}{l}\text { - Comitê Executivo de Estudos Integrados da Bacia } \\
\text { Hidrográfica do Rio Paraíba do Sul }\end{array}$ \\
\hline CEIVAP & - Comitê de Integração da Bacia do Paraíba do Sul \\
\hline CETAE & - Centro de Tecnologias Ambientais e Energéticas \\
\hline CETESB & - Companhia de Tecnologia de Saneamento Ambiental \\
\hline CNAEE & - Conselho Nacional de Águas e Energia Elétrica \\
\hline CNRH & - Conselho Nacional de Recursos Hídricos \\
\hline COFEHIDRO & $\begin{array}{l}\text { - Conselho de Orientação do Fundo Estadual de Recursos } \\
\text { Hídricos }\end{array}$ \\
\hline COGERH & $\begin{array}{l}\text { - Companhia de Gestão de Recursos Hídricos do Estado de } \\
\text { Ceará }\end{array}$ \\
\hline CONAMA & - Conselho Nacional do Meio Ambiente \\
\hline CONSEMA & - Conselho Estadual do Meio Ambiente \\
\hline COVAP & - Comissão do Vale do Paraíba \\
\hline CPTI & $\begin{array}{l}\text { - Cooperativa de Serviços e Pesquisas Tecnológicas e } \\
\text { Industriais }\end{array}$ \\
\hline CRH & - Conselho Estadual de Recursos Hídricos \\
\hline CRHi & - Coordenadoria de Recursos Hídricos \\
\hline CT & - Câmara Técnica \\
\hline
\end{tabular}




$\begin{array}{ll}\text { CT PG } & \text { - CT Planejamento e Gestão } \\ \text { DAEE } & \text { - Departamento de Águas e Energia Elétrica de São Paulo } \\ \text { DNAE } & \text { - Departamento Nacional de Águas e Energia } \\ \text { DNAEE } & \text { - Departamento Nacional de Águas e Energia Elétrica } \\ \text { DNOCS } & \text { - Departamento Nacional de Obras contra a Seca } \\ \text { DNOS } & \text { - Departamento Nacional de Obras e Saneamento } \\ \text { DNPM } & \text { - Departamento Nacional de Pesquisa Mineral } \\ \text { EIA/RIMA } & \text { - Estudo de Impacto Ambiental / Relatório de Impacto } \\ & \text { Ambiental } \\ \text { FACTE } & \text { - Fundação de Apoio à Ciência, Tecnologia e Educação } \\ \text { FAI } & \text { - Fundação de Apoio Institucional para o Desenvolvimento } \\ & \text { Científico e Tecnológico }\end{array}$

FEHIDRO - Fundo Estadual de Recursos Hídricos

FESB - Fundo Estadual de Saneamento Básico

FIPAI - Fundação para o Incremento da Pesquisa e do Aperfeiçoamento Industrial

GT CA - Grupo Técnico da Cobrança pelo Uso da Água

IBAMA - Instituto Brasileiro do Meio Ambiente e dos Recursos Naturais Renováveis

IDH - Índice de Desenvolvimento Humano

IPT - Instituto de Pesquisas Tecnológicas do Estado de São Paulo

LABGEO - Laboratório de Recursos Hídricos e Avaliação Geoambiental

MMA - Ministério do Meio Ambiente

ONGs - organizações não governamentais

ONU - Organização das Nações Unidas

PCJ - Piracicaba, Capivari e Jundiaí

PERH - Plano Estadual de Recursos Hídricos

PLANASA - Plano Nacional de Saneamento Básico

PNRH - Política Nacional de Recursos Hídricos

PNUMA - Programa das Nações Unidas para o Meio Ambiente

SAGE - Schéma de Aménagement et de Gestion des Eaux (Plano 
de Ordenamento e de Gestão das Águas)

SDAGE - Schéma Directeur de Aménagement et de Gestion des Eaux (Plano Diretor de Ordenamento e de Gestão das Águas)

SEADE - Fundação Sistema Estadual de Análise de Dados

SEMA - Secretaria Especial do Meio Ambiente

SIAPREH - Sistema de Acompanhamento e Avaliação da Implementação da Política de Recursos Hídricos

SIGRH - Sistema Integrado de Gerenciamento dos Recursos Hídricos

SINGREH - Sistema Nacional de Gerenciamento de Recursos Hídricos

SMA - Secretaria do Meio Ambiente do Estado de São Paulo

SRHU - Secretaria de Recursos Hídricos e Ambiente Urbano

TJ - Tietê - Jacaré

TVA - Tennessee Valley Authority

UFSCar - Universidade Federal de São Carlos

UGRHI - Unidade de Gerenciamento de Recursos Hídricos

UNESCO - United Nations Educational, Scientific and Cultural Ciência Organizations (Organização das Nações Unidas para a Educação, a e a Cultura)

UNESP - Universidade Estadual Paulista

UNIARA - Centro Universitário de Araraquara

USP $\quad$ - Universidade de São Paulo 


\section{LISTA DE FIGURAS}

PÁG.

Figura 1 - Sistema Nacional de Gerenciamento de Recursos Hídricos

Figura 2 - Mapa das Unidades de Gerenciamento de Recursos Hídricos (UGRHIs) do Estado de São Paulo 87

Figura 3 - Mapa da Bacia Hidrográfica do Tietê - Jacaré 126 


\section{LISTA DE GRÁFICOS}

A numeração dos gráficos do Capítulo 7, excepcionalmente, segue a numeração das perguntas do questionário para facilitar a associação das respostas obtidas às questões formuladas, e estão listados na ordem em que são apresentados no documento.

PÁG.

Gráfico 1.10 - Distribuição dos representantes por faixa etária

Gráfico 2.3 - Tempo de participação do representante no comitê TJ 157

Gráfico 3.1 - Conhecimentos específicos sobre recursos hídricos 163

Gráfico 3.2 - Conhecimentos sobre a Política Estadual de Recursos Hídricos

Gráfico 4.1 - Recebimento de informações sobre andamento da implantação dos instrumentos de gestão na bacia Tietê - Jacaré

Gráfico 4.2 - Conhecimento do Plano da Bacia do Tietê - Jacaré 166

Gráfico 4.7 - Conhecimento dos critérios definidos pelo Comitê Tietê - Jacaré para a Cobrança pelo Uso da Água

Gráfico 5.1 - Recebimento de informações sobre andamento das atividades dos comitês do Estado de São Paulo

Gráfico 4.11 - Satisfação do representante com a gestão das águas da bacia

Gráfico 4.12 - Satisfação de sua entidade com a gestão das águas da bacia

Gráfico 5.2 - Satisfação do representante com a gestão das águas no estado

Gráfico 5.3 - Satisfação de sua entidade com a gestão das águas no estado 


\section{LISTA DE QUADROS}

PÁG.

Quadro 1 - Questionário segundo categorias de análise 122 e 123

Quadro 2 - Informações sobre Representantes 146

Quadro 3 - Questões sobre participação dos envolvidos 149

Quadro 4 - Questões sobre representatividade da entidade 154

Quadro 5 - Questões sobre representatividade da representante 156

Quadro 6 - Questões sobre capacitação técnica 160

Quadro 7 - Questões sobre comunicação 165

Quadro 8 - Questões sobre o processo do Plano de Bacia 169

Quadro 9 - Questões sobre o processo da cobrança 171

Quadro 10 - Questões sobre satisfação com a gestão das águas 173 


\section{LISTA DE TABELAS}

A numeração das tabelas do Capítulo 7, excepcionalmente, segue a numeração das perguntas do questionário para facilitar a associação das respostas obtidas às questões formuladas, e estão listadas na ordem em que são apresentadas no documento.

PÁG.

Tabela 1 - Dados dos Comitês de Bacias Hidrográficas do Estado de São Paulo 88

Tabela 2 - Participantes na pesquisa por segmento 144

Tabela 3 - Questionários respondidos por segmento e por forma de resposta 144

Tabela 1.10 - Distribuição dos representantes por idade e por segmento

Tabela 1.12 - Distribuição dos representantes por gênero 148

Tabela 2.11 - Recebimento de ajuda financeira para ir às reuniões 150

Tabela 2.12 - Satisfação quanto às condições para participação no comitê 151

Tabela 2.2 - Início da participação de sua entidade no comitê 154

Tabela 2.9 - Consulta a outras entidades do seu segmento 155

Tabela 2.10 - Divulgação a outras entidades do seu segmento 156

Tabela 2.5 - Recebimento de apoio técnico de pessoas de sua entidade para sua atuação no comitê 159

Tabela 2.6 - Prática de compartilhar ideias com outras pessoas da entidade

Tabela 2.7 - Busca por opiniões de colegas e/ou superiores 159

Tabela 2.8 - Levantamento de necessidades da entidade 160

Tabela 1.11 - Grau de instrução dos representantes entrevistados 161

Tabela 1.3 - Formação dos representantes por segmento 161

Tabela 3.1 - Conhecimentos específicos sobre recursos hídricos 162

Tabela 3.3 - Citações dos instrumentos de gestão de recursos hídricos

Tabela 4.3 - Demonstração dos principais problemas e demandas da bacia pelo Plano de Bacia 169

Tabela 4.4 - Participação de sua entidade na elaboração do Plano de Bacia 
Tabela 4.5 - Participação das demais entidades na elaboração do Plano

Tabela 4.6 - Importância da participação dos diversos segmentos para a qualidade do Plano de Bacia

Tabela 4.8 - Satisfação de sua entidade com os critérios formulados para a cobrança pelo uso da água

Tabela 4.9 - Participação sua ou de sua entidade no GT Cobrança 172

Tabela 4.10 - Participação significativa dos diversos segmentos no processo de formulação dos critérios de cobrança 173

Tabela 4 - Participação da nova gestão na pesquisa 192 
Cuidar das águas é uma missão de toda a sociedade e a gestão brasileira dos recursos hídricos só poderá ser eficaz com a parceria e o comprometimento de todos nós!

Mensagem da Comissão Organizadora do XVIII Simpósio Brasileiro de Recursos Hídricos aos congressistas (ABRH, 2009, p. 2) 


\section{INTRODUÇÃO E JUSTIFICATIVA DA PESQUISA}

Água é saúde. Essa frase mostra que a água, em quantidade e qualidade adequadas, é base para a promoção da saúde pública. A água é essencial ao abastecimento humano, à produção econômica, industrial e agrícola, enfim, é fundamental para a vida. É uma riqueza natural insubstituível com grande valor econômico.

As demandas de água apresentaram um crescimento acentuado no mundo todo devido, não só ao crescimento da população, mas também à aceleração do processo de urbanização, à intensificação de atividades agrícolas e à industrialização crescente, representando um aumento de $700 \%$ das retiradas mundiais de água em um século (MATSUURA, 2003). Apesar da quantidade de água fresca no mundo ser suficiente para cobrir as necessidades totais de água potável, a distribuição de recursos hídricos é irregular, ocasionando problemas de disponibilidade hídrica em muitas bacias do planeta (MATSUURA, 2003).

TUNDISI (2003) mostra os valores anuais de disponibilidade de água dos países variando de $10 \mathrm{~m}^{3} / \mathrm{hab}$, registrado no Kuwait, a $812.121 \mathrm{~m}^{3} / \mathrm{hab}$, encontrado na Guiana Francesa. Esses valores, calculados considerandose o potencial hídrico da região e a população local, quando abaixo de 500 $\mathrm{m}^{3} / \mathrm{hab}$ representam escassez de água. Regiões com valores anuais acima de $100.000 \mathrm{~m}^{3} / \mathrm{hab}$ são consideradas muito ricas em água (REBOUÇAS, 1999). O Brasil aparece em 25ํ lugar dentre os países com maior disponibilidade hídrica anual, com $48.314 \mathrm{~m}^{3} / \mathrm{hab}$ (TUNDISI, 2003), classificado como rico em água (REBOUÇAS, 1999).

Apesar de tal classificação e de contar com cerca de $12 \%$ de toda a água doce existente na Terra, sua distribuição apresenta grandes diferenças pelas regiões do país, sendo que $68,5 \%$ deste total estão localizados na 
região menos urbanizada, a Região Norte (PEREIRA e FERREIRA, 2008). Conforme mostrado por REBOUÇAS (1999), a disponibilidade hídrica anual no país varia de $1.270 \mathrm{~m} / \mathrm{hab}$ no Estado de Pernambuco, potencial hídrico classificado apenas como regular, a $1.506 .488 \mathrm{~m}^{3} / \mathrm{hab}$ encontrada em Roraima. O valor anual encontrado para o Estado de São Paulo é $2.209 \mathrm{~m}^{3} / \mathrm{hab}$, classificado como potencial hídrico suficiente.

A qualidade da água também se tornou preocupante, pois houve um aumento da produção de dejetos aquáticos em vinte vezes ao longo do século (MATSUURA, 2003). A utilização de agrotóxicos na agricultura e os despejos de esgotos domiciliares e industriais, sem 0 tratamento adequado, provocaram a poluição dos rios, lagos, reservatórios e aquíferos subterrâneos (PEREIRA e FERREIRA, 2008). Com base em estudos efetuados nas bacias dos rios Piracicaba, Capivari e Jundiaí, BRAGA (2003) afirma que "o uso urbano não industrial, embora responda apenas por cerca de um terço da demanda, contribui com mais da metade das cargas poluidoras (tomando-se como indicador tDBO/dia) dos mananciais" (p. 113).

Apesar de algumas iniciativas isoladas em relação aos problemas provocados pela degradação ambiental, "a abordagem da questão ambiental tal como contemporaneamente formulada é bem mais recente, datando dos anos 1970, quando emerge na agenda internacional entre os grandes problemas do mundo contemporâneo" (SMA, 2004, p. 34). Visando a negociação de parâmetros comuns para direcionar políticas, pesquisas e práticas institucionais para a proteção ambiental global, surgem as Conferências e Acordos Institucionais.

A primeira delas, a Conferência das Nações Unidas sobre o Meio Ambiente, aconteceu em Estocolmo, em 1972, e tratou também da poluição das águas (CARDOSO, 2003). Na Conferência das Nações Unidas sobre a Água, em Mar del Plata, Argentina, em 1977, primeira 
conferência dedicada exclusivamente ao tema água, recomendou-se uma maior atenção ao planejamento integrado dos recursos hídricos e a formulação de políticas nacionais específicas de gestão das águas em diversos países (CEPAL, 1998). Na Conferência Internacional sobre a Água e o Meio Ambiente celebrada em Dublin, na Irlanda, em 1992, foram definidos quatro princípios a serem seguidos nas esferas local, nacional e internacional, influenciando as novas políticas públicas de gerenciamento dos recursos hídricos. Vários eventos mundiais se seguiram, demonstrando a existência de "uma preocupação de abrangência global, não apenas nos países onde já se verificam situações de escassez de água, mas também nos demais países, onde a inexistência de políticas de uso racional da água poderá rapidamente levar a situações de escassez" (PIO, 2005, p. 44).

O Brasil sofreu influência direta dessas conferências e do movimento ambientalista global. A criação da Secretaria Especial do Meio Ambiente (SEMA), em 1973, e a edição da Lei Federal no 6938, em 1981, instituindo a Política Nacional de Meio Ambiente, foram marcos do início de uma "nova institucionalidade política que tem como seu objeto o meio ambiente" (SMA, 2004, p. 34). A sensibilização para a necessidade de se ter uma política de recursos hídricos com base no gerenciamento integrado e participativo, voltada aos usos múltiplos da água, cresce entre as comunidades técnicas e políticas brasileiras (PIO, 2005).

A partir da Constituição de 1988, que estabeleceu que a água é um bem público e considerou a necessidade de uma política integrada entre os corpos d'água e as terras que os circundam, vários estados aprovaram leis que reorganizaram o sistema de gestão dos recursos hídricos: São Paulo em 1991, Ceará em 1992 e Santa Catarina, Distrito Federal, Rio Grande do Sul, Minas Gerais e Bahia nos anos seguintes (NORONHA, 2006). 
Em 1997, através da Lei Federal no 9433, foi instituída a Política Nacional de Recursos Hídricos (PNRH) e criado o Sistema Nacional de Gerenciamento de Recursos Hídricos (SINGREH), que prevê a implementação de instrumentos de gestão e a constituição de comitês de bacia e de seus braços executivos, as agências de bacia. Estas instituições se espelharam no modelo francês de gerenciamento de recursos hídricos (CARDOSO, 2003), que tem como diretriz a ampla participação dos usuários de água (CAVINI, 2009).

O modelo adotado pela Política Nacional e pelas Políticas estaduais preconiza a gestão integrada dos usos múltiplos da água, tendo por base a bacia hidrográfica. Propõe um modelo descentralizado e participativo, baseado na criação de comitês de bacia compostos por representantes de órgãos dos diferentes níveis de governo (federal, estadual e municipal), dos usuários da água e das entidades não governamentais da sociedade civil. Tais comitês são colegiados com funções deliberativas e funcionam como Parlamento das Águas de uma bacia. Partindo da premissa de que as águas são usadas por muitos agentes com interesses diferentes, é necessário que todos participem do sistema de gerenciamento das águas, com negociações e decisões coletivas (NORONHA, 2006).

Esses órgãos colegiados têm poder de decisão sobre uma série de questões importantes na sua bacia, como priorização de ações para aplicação de recursos e definições sobre valores a serem adotados por ocasião do processo da cobrança (CARDOSO, 2003). Também cabe a eles a articulação entre os diversos agentes, a atuação em primeira instância em caso de conflito e a aprovação do plano de recursos hídricos da bacia (PORTO e PORTO, 2008). Desde 1988, ano em que foram criados os primeiros comitês de bacia no Rio Grande do Sul (NORONHA, 2006), o processo de formação desses colegiados vem sendo desenvolvido em vários estados com a participação do poder público, dos usuários e das comunidades. 
A Política Nacional e as Políticas Estaduais de Recursos Hídricos instituem instrumentos de gestão de recursos hídricos, dentre os quais cabe destacar 5 instrumentos presentes em várias delas: Planos de Recursos Hídricos; cobrança pelo uso dos recursos hídricos; enquadramento dos corpos d'água em classes segundo os usos preponderantes da água; outorga de direito de uso dos recursos hídricos; e Sistema de Informações sobre Recursos Hídricos. Tais instrumentos encontram-se em diferentes estágios de implementação nas bacias hidrográficas brasileiras, sendo que alguns deles encontram-se implantados somente em algumas bacias.

Essa situação mostra que a existência de legislação adequada não é suficiente para possibilitar a implementação dos instrumentos de gestão de recursos hídricos, e se atingir a qualidade e a quantidade de água necessárias para os múltiplos usos em algumas bacias críticas.

A situação atual da gestão de recursos hídricos no Brasil tem sido objeto de vários estudos e de encontros em diversos pontos do país. Alguns aspectos têm sido citados em vários deles. Esta pesquisa elencou e analisou os principais aspectos referentes ao processo participativo.

O primeiro desses aspectos diz respeito ao princípio da participação dos envolvidos no planejamento e na tomada de decisão. As decisões tomadas pelos comitês são elaboradas através de articulação e construção de consensos, formam pactos e tendem a ser mais sustentáveis, porém costumam ser mais demoradas devido ao tempo necessário para a tomada de decisão por meio de processos participativos (PORTO e PORTO, 2008).

Como cabem aos comitês decisões significativas para a gestão integrada das bacias, vários autores apontam a importância da capacitação de membros e participantes das decisões e do acesso à informação, dois 
outros aspectos a serem analisados nesta pesquisa. PORTO e PORTO (2008, p.50) afirmam que "o bom funcionamento e a decisão qualificada dependem de capacitação e de bons sistemas de informação, ambos, infelizmente, quase sempre ausentes nos comitês em funcionamento no Brasil".

Tal pensamento é compartilhado por MAGALHÃES JÚNIOR (2007, p.39):

"O atual Sistema Nacional de Gerenciamento de Recursos Hídricos tem, entre seus princípios mais difundidos, a descentralização e a participação social em nível de organismos de bacia. Porém, os Comitês de Bacia Hidrográfica dependem, entre outros fatores, da disponibilidade, da qualidade e da forma de tratamento e utilização de dados em escalas adequadas, ou seja, os $\mathrm{CBH}$ dependem da qualidade informacional dos dados (capacidade de transmitir conhecimento). Para a consolidação dos CBHs no Brasil a existência de dados e informações é essencial".

PEREIRA e JOHNSSON (2005) afirmam, porém, que frequentemente isto não é observado, o que propicia distorções conceituais significativas, debates acalorados e, em alguns casos, revisões futuras de propostas. Afirmam ainda que, "mesmo em comitês de bacia mais ativos, observa-se significativa assimetria no processo decisório entre os diferentes setores ali representados" (p.68). Segundo as autoras:

"A capacitação dos membros dos comitês de bacia, sobretudo dos setores tradicionalmente mais periféricos no processo decisório, constitui, portanto, o maior desafio da gestão participativa em bacias nacionais. Trata-se de condição indispensável à participação qualificada e à democratização do processo decisório" (p.68).

Em relação à participação da sociedade civil nos comitês, CAMPOS (2005, p. 55) observa que "dada a multiplicidade de interesses presentes no interior do segmento, torna-se bastante difícil conseguir uma coesão interna, não se aproveitando de todos benefícios que uma ação em conjunto poderia trazer". Seguindo esse pensamento, percebe-se que aspectos ligados à representatividade da entidade e representatividade do representante também interferem nas atividades dos comitês. 
Atualmente a qualidade técnica dos estudos e o estágio de implementação dos instrumentos de gestão nos Comitês das Bacias dos rios Piracicaba, Jundiaí e Capivari (CBH PCJ) (GRISOTTO, 2003), bem como nos Comitês da Bacia do rio Paraíba do Sul (CBH PS) e de Integração da Bacia do Paraíba do Sul (CEIVAP) (PEREIRA e JOHNSSON, 2005) são reconhecidos pelos profissionais envolvidos neste assunto, em especial pelo pioneirismo na implementação da cobrança pelo uso dos recursos hídricos.

Porém, outros comitês ainda não contam com instrumentos implantados, apesar de contarem com estrutura similar à encontrada nos comitês em estágio mais avançado. Isso dificulta a execução de ações que possam propiciar melhorias de qualidade ou de quantidade das águas da bacia.

Estas diferenças encontradas nas bacias do Estado de São Paulo suscitam a busca pelas suas causas. Alguns estudos apontam que, dentre os fatores que podem contribuir para esse quadro, encontra-se a participação dos atores nos comitês de bacia. Surge, então, a pergunta:

A participação dos atores envolvidos nos comitês de bacias hidrográficas contribui para a implementação dos instrumentos de gestão de recursos hídricos no âmbito da bacia hidrográfica?

Para se chegar à resposta desta questão, outras precisarão ser respondidas:

- Qual é a estrutura de gestão dos comitês de bacia do Estado de São Paulo?

- Como se dá a participação dos diversos atores nos processos decisórios nos comitês de bacias hidrográficas?

- Como é a participação dos diversos segmentos nos processos relacionados à implantação dos instrumentos de gestão nos comitês de bacia? 
- Quais ações podem ser feitas, quanto à participação dos membros, para aprimorar as atividades dos comitês?

Considerando os bons resultados já alcançados por alguns comitês no Brasil, e a necessidade de melhoria na gestão das águas para garantia da saúde da população, esta pesquisa se propôs a analisar o processo de participação em comitês de bacia hidrográfica do Estado de São Paulo e suas implicações na implementação dos instrumentos de gestão de recursos hídricos. Essa análise teve como foco o processo participativo, e não a qualidade dos instrumentos de gestão implementados.

Foi escolhido como estudo de caso, o Comitê da Bacia Hidrográfica do Tietê - Jacaré (CBH TJ). Trata-se de um comitê de porte médio, tanto quanto ao número de municípios integrantes do comitê e à área de drenagem da bacia correspondente, quanto ao total de membros e número de câmaras técnicas que nele atuam; onde a implantação de instrumentos está avançada em relação à média dos comitês do estado; e possui apenas rios de dominialidade estadual. Essa situação proporciona condições para a aplicação das conclusões e constatações levantadas neste comitê para outros comitês do Estado. Tal situação também possibilita que as recomendações finais feitas com base na bacia do Tietê - Jacaré sejam levadas para outras bacias paulistas. 


\section{OBJETIVOS DA PESQUISA}

O objetivo geral deste trabalho é analisar o processo de participação em comitês de bacia hidrográfica do Estado de São Paulo e suas implicações na implementação de instrumentos de gestão de recursos hídricos no âmbito da bacia hidrográfica.

Esse objetivo deverá ser atendido através da busca dos seguintes objetivos específicos:

- Identificar os fatores-chave relacionados à participação em comitês de bacias hidrográficas para o processo de implementação dos instrumentos de gestão;

- Levantar e analisar a participação dos representantes do Comitê da Bacia Hidrográfica do Tietê - Jacaré;

- $\quad$ Analisar a participação dos diversos segmentos do Comitê Tietê Jacaré nos processos decisórios relacionados à implementação dos instrumentos de gestão nesta bacia; e

- Identificar pontos de melhoria do processo participativo em comitês de bacia hidrográfica para aprimoramento da gestão de recursos hídricos. 


\section{METODOLOGIA}

Trata-se de uma pesquisa exploratória, pois tem como objetivo proporcionar maior familiaridade com o problema da gestão de recursos hídricos, visando torná-lo mais explícito e a construir hipóteses sobre as questões levantadas (GIL, 2002). Foi desenvolvida em três etapas: pesquisa bibliográfica, descrita no item 3.1; pesquisa documental, descrita no item 3.2; e estudo de caso, cuja metodologia utilizada durante sua elaboração está apresentada no item 3.3, e a empregada para a análise dos resultados está no item 3.4.

\subsection{PESQUISA BIBLIOGRÁFICA}

Sua primeira parte consistiu em uma pesquisa bibliográfica, com o objetivo de conhecer a gestão de recursos hídricos em outros países, em especial na França; no Brasil; e no Estado de São Paulo, por meio de sua legislação e de trabalhos sobre o tema. Fez-se uma retrospectiva histórica da gestão das águas no país, incluindo aspectos de outros estados brasileiros, porém com menor aprofundamento. Com o objetivo de identificar os fatores-chave relacionados à participação em comitês de bacias hidrográficas, foram consultados trabalhos sobre a participação dos diversos atores na gestão de recursos hídricos e, também, na formulação de políticas públicas.

Esta fase abrangeu consulta a livros, artigos científicos de periódicos e teses ou dissertações, levantados por meio da busca das seguintes palavras-chave: gestão de recursos hídricos, gestão da água, governança da água, comitês de bacia hidrográfica e participação social. 


\subsection{PESQUISA DOCUMENTAL}

A segunda parte consistiu em pesquisa documental, com o objetivo de levantar dados de comitês do Estado de São Paulo, com maior atenção às questões referentes aos instrumentos de gestão implantados e à participação dos diversos atores na gestão de bacias hidrográficas paulistas. A título de comparação, foi também levantada a situação da implantação dos instrumentos de gestão em outros estados, porém com menor profundidade.

Foram realizadas pesquisas nos sites do Sistema Integrado de Gerenciamento dos Recursos Hídricos (SIGRH) e de alguns órgãos gestores do governo federal e estadual para levantamento de documentos, como relatórios, estatutos e deliberações, visando a comparação da composição dos diversos colegiados e do levantamento do estágio de implementação dos instrumentos de gestão nas bacias do Estado.

\subsection{ESTUDO DE CASO}

A partir da teoria apreendida e dos conceitos levantados nas fases anteriores, a terceira parte consistiu no estudo de caso, quando foi realizado um aprofundamento da situação encontrada no Comitê da Bacia Hidrográfica do Tietê - Jacaré. A metodologia desta fase prática consistiu, em linhas gerais, de um aprofundamento na pesquisa documental, na aplicação de questionários aos membros representantes dos 3 segmentos que atuam no comitê, preferencialmente por meio de entrevistas presenciais, e na análise dos resultados obtidos. A escolha do comitê de bacia piloto e dos instrumentos de gestão a serem avaliados, bem como as demais etapas necessárias, estão detalhadas a seguir. 
3.3.1 Escolha do comitê de bacia piloto e do universo de pesquisa

A escolha do comitê de bacia a ser pesquisado foi feita no final do ano de 2008, com base em algumas condições consideradas necessárias tanto para o andamento desta pesquisa, como para possibilitar a aplicação dos resultados aqui alcançados em outras bacias do Estado. Foram elas:

- Bacia de porte médio em relação às demais bacias do Estado, quanto ao número de municípios como também quanto à área territorial e à população;

- Comitê de porte médio em relação ao número de membros e de Câmaras Técnicas em funcionamento;

- Bacia formada por cursos d'água somente de domínio estadual, estando assim sujeitos apenas à legislação estadual;

- Instrumentos de gestão implantados ou em fase avançada de implantação, em especial o Plano de Bacia e a Cobrança pelo uso da água;

- Poucos estudos publicados sobre este comitê; e

- Facilidade de acesso pela pesquisadora, residente na capital, aos municípios da bacia.

Através da biblioteca digital de teses e dissertações da USP, buscou-se trabalhos sobre a bacia Tietê - Jacaré e seu comitê, em especial na biblioteca da Escola de Engenharia de São Carlos, da USP. Foi feita nova pesquisa a documentos específicos deste comitê no site do SIGRH e em sua sede, localizada no Escritório de Apoio de Araraquara do Departamento de Águas e Energia Elétrica de São Paulo (DAEE). Foram analisados atas de reuniões plenárias, relatórios, como também artigos em jornais e revistas.

Por ser a instância máxima de decisão no comitê, foi escolhido como universo para a aplicação das entrevistas os 36 membros titulares que compõem o plenário deste colegiado, atuantes na gestão 2009 - 2011, 
conforme apresentado no Anexo 11.2. Esta pesquisa iniciou no ano de 2009, e a aplicação dos questionários foi programada para meados de 2010, possibilitando assim um período de adequação dos novos membros às atividades de representação junto a esse comitê.

\subsubsection{Escolha dos instrumentos de gestão a serem avaliados}

Optou-se por focar a avaliação da implantação dos instrumentos de gestão nesta bacia a apenas dois deles, o Plano de Bacia e a Cobrança pelo uso dos recursos hídricos, para possibilitar tanto um maior detalhamento durante a pesquisa documental, como também uma abordagem mais detalhada durante a aplicação desses questionários. Visto que o objetivo deste trabalho é analisar o processo participativo, procurou-se também dar ênfase às fases do processo de tais instrumentos que estão sob a responsabilidade dos comitês.

A escolha do Plano de Bacia, cuja aprovação é de responsabilidade dos membros dos comitês de bacia, se deu em razão da importância de tal instrumento dentre os demais. Os instrumentos de gestão preconizados pelas políticas de recursos hídricos, a serem descritas no Capítulo 5, guardam uma grande interdependência e complementaridade. É nos planos de bacias que são definidas as prioridades necessárias para 0 instrumento Outorga, as destinações de uso adotadas pelo instrumento Enquadramento, as diretrizes necessárias para o instrumento Cobrança, bem como os programas de investimentos para destinação das verbas deste instrumento e do FEHIDRO (PEREIRA, 2003).

GRANZIERA (2001) diz que:

"Aos Comitês de Bacia Hidrográfica cabe aprovar os planos de bacia hidrográfica. Essa atribuição, como garantia da efetividade do processo de elaboração do plano, está diretamente relacionada com o sistema de decisão que tiver sido adotado por parte de cada comitê, em sua 
instalação. Em outras palavras, é necessário que o sistema decisório do Comitê seja de tal forma estabelecido que necessariamente seja exarada uma decisão, por maioria, ou por outro critério que possa representar o desejo predominante de seus integrantes" (p.143).

Segundo GRISOTTO (2003), durante a coleta de dados para preparação do Plano de Bacia é de fundamental importância o envolvimento das entidades e órgãos públicos e privados de ensino e pesquisa da bacia; e para a construção do Plano é imprescindível a participação dos usuários de água da bacia. O autor afirma que a qualidade e a eficácia do Plano de Bacia Hidrográfica estão vinculadas diretamente ao grau de articulação entre as entidades detentoras dos cadastros e fontes de informação e a entidade que deverá elaborar o Plano. Após a aprovação pelos Comitês, o sucesso de sua execução e do acompanhamento de sua implementação depende do grau de envolvimento dos segmentos gestores estaduais, municipais, dos usuários e da Sociedade Civil e da articulação estabelecida entre eles, "principalmente porque é através do acompanhamento de sua implementação que podem ser (re)discutidas atualizações, melhorias e aperfeiçoamentos aplicáveis aos Planos" (GRISOTTO, 2003, p. 62),

Devido à importância da implantação da cobrança pelo uso dos recursos hídricos para a efetiva gestão das bacias hidrográficas, este foi o segundo instrumento escolhido para ser acompanhado nesta pesquisa. Tal importância se deve, não só por representar uma fonte de recursos financeiros para financiar programas e intervenções contemplados nos planos de bacia, mas principalmente por ser indicativo do real valor da água, por incentivar seu uso racional (SMA, 2004) e por estimular a nãopoluição (PEREIRA, 2003). Tal pensamento é compartilhado por SOUZA (1993), ao afirmar que a cobrança "deve ser utilizada como instrumento de gestão de recursos hídricos e, portanto, como mecanismo regulador de apropriação de recursos hídricos e de ordenamento da ocupação 
territorial" (p. 107) e que "o fundo financeiro, que é importante, deve ser uma consequência da cobrança e não o seu objetivo" (p. 108).

A cobrança deve ocorrer "de acordo com as peculiaridades de cada bacia e conforme o interesse local" (MARIANO, 1996, p. 34). GRISOTTO (2003) ressalta que:

"A principal dificuldade de implementação da sistemática de cobrança está no desconhecimento ainda bastante generalizado sobre a sua prática, custos e benefícios, tanto no setor que efetuará a cobrança quanto no que será cobrado, gerando inseguranças e predisposições negativas. Prova disso é o suposto impacto sobre a estrutura de custos das empresas sujeitas à nova tarifação e à possibilidade de que ela seja repassada sob a forma de aumento de preços, gerando expectativas negativas" (p. 66).

Cabe aos comitês de bacia a formulação dos critérios da cobrança pelo uso dos recursos hídricos em cada bacia para posterior encaminhamento ao Governo do Estado, após aprovação pelo Conselho Estadual de Recursos Hídricos (CRH). Esta pesquisa buscou avaliar o processo empregado pelo Comitê Tietê - Jacaré para atender esta responsabilidade, ressaltando aqui a importância da ampla participação dos órgãos gestores e dos usuários nesta atividade, independente do segmento que representam.

O instrumento outorga de direito de uso dos recursos hídricos, já implantado em todo o Estado de São Paulo, não foi considerado adequado para ser estudado nesta pesquisa por ser uma atribuição do órgão gestor, e não dos comitês de bacia.

É importante salientar que esta pesquisa não se propôs a avaliar o Plano da Bacia do Tietê - Jacaré ou os critérios estipulados para a cobrança nesta bacia, mas sim o processo participativo dos membros deste comitê relacionado a estes dois instrumentos de gestão. 
3.3.3 Elaboração do questionário e Avaliação da pesquisa pelo Comitê de Ética da Faculdade de Saúde Pública da USP

Após este aprofundamento, foi elaborado um questionário a ser aplicado a todos os membros titulares deste comitê (ver Anexo 11.5), com perguntas abertas e fechadas, que teve como objetivo levantar seu perfil, seu nível de conhecimento dos assuntos tratados e seu grau de comprometimento com as atividades do comitê, sua opinião sobre a participação dos diversos atores neste colegiado e seu conhecimento sobre o processo de aprovação do Plano de Bacia e sobre a formulação dos critérios da cobrança pelo uso dos recursos hídricos na bacia. Para a elaboração deste questionário, foram consultadas outras pesquisas realizadas também com base na aplicação de questionário (GRISOTTO, 2003; SANTOS, 2008; PROTA, 2009; NUNES, 2010) para auxiliar, tanto na formulação das questões, como também na forma de aplicação.

Por envolver contato direto com pessoas nas entrevistas, foi necessário submeter tal pesquisa ao Comitê de Ética da Faculdade de Saúde Pública da USP. Para isso, foram elaborados vários documentos, dentre os quais destacam-se:

- Consulta ao Comitê de Bacia Tietê - Jacaré, na figura de seu secretário executivo, para a aprovação do desenvolvimento desta pesquisa (Anexo 11.1);

- Termo de Consentimento, assinado por todos os entrevistados no início de cada entrevista, como forma de esclarecimento e garantia de sigilo total das informações obtidas nesta pesquisa (Anexo 11.4); e

- Termo de Responsabilidade, elaborado por esta pesquisadora, como garantia do anonimato e do sigilo das respostas e comprometimento de devolução dos resultados obtidos ao CBH TJ (Anexo 11.6).

Esta proposta de pesquisa foi aprovada no Comitê de Ética em fevereiro de 2010. 


\subsubsection{Aplicação dos questionários como pré-teste}

A primeira reunião plenária do CBH TJ de 2010 aconteceu no dia 28 de junho, no Salão Paroquial, em Itaju, quando foi feita a apresentação desta pesquisa e, visando aumentar a receptividade destes às entrevistas, foi solicitada a colaboração dos membros do comitê para a aplicação do questionário.

Em junho de 2010, este questionário foi aplicado primeiramente a 5 membros do comitê, contatados por intermédio do secretário executivo, para testar a aplicabilidade das questões e possibilitar ajustes, se necessários, antes da apresentação na reunião plenária. Visando a transcrição das respostas, foram feitas anotações pela própria pesquisadora, além de gravação digital.

Para facilitar a aplicação do questionário, as perguntas foram apresentadas aos membros do comitê em uma sequência de assuntos diferentes, divididas em 5 blocos:

1. Informações sobre o representante do CBH TJ;

2. Informações sobre a entidade que representa e sua atuação no comitê;

3. Informações gerais sobre a gestão de recursos hídricos;

4. Suas impressões sobre a gestão atual da Bacia do Tietê - Jacaré; e

5. Suas impressões sobre a gestão atual dos recursos hídricos do Estado de São Paulo.

Dentre as questões formuladas nestas primeiras entrevistas, percebeu-se que as questões de Informações sobre o representante demandavam muito tempo e optou-se por mostrar o cadastro já obtido junto à secretaria executiva do comitê para confirmação no momento da entrevista e efetuar 
apenas as questões restantes 1.3, 1.4, 1.9 e 1.10, agilizando assim a aplicação do $1^{\circ}$ bloco de questões.

Dentre as questões referentes às Informações sobre a entidade, do $2^{\circ}$ bloco, foi constatada a dificuldade de compreensão das perguntas 2.6 a 2.8 para membros que representam uma categoria, ou mesmo para membros que representam outra entidade diferente de sua empregadora. Foram então criadas as questões 2.9 e 2.10 para os casos de entidades que representam categorias.

Nos casos em que, em resposta a perguntas anteriores, as políticas de recursos hídricos e os instrumentos de gestão foram também abordados pelos entrevistados, possibilitando obter as respostas às questões do $3^{\circ}$ bloco, estas perguntas não foram apresentadas diretamente, agilizando assim a aplicação do questionário.

No $4^{\circ}$ bloco, as questões se concentraram na opinião dos entrevistados sobre a participação de sua entidade e das demais durante o processo de aprovação do Plano da Bacia e de formulação de critérios para a Cobrança pelo uso dos recursos hídricos. Parte destas questões foi omitida nos casos em que os entrevistados começaram a frequentar o comitê recentemente e não participaram destas atividades.

Após as questões finais sobre a satisfação dos entrevistados e das entidades que representam sobre a gestão de recursos hídricos na bacia e no Estado, do $5^{\text {o }}$ bloco, percebeu-se a necessidade de possibilitar comentários finais, sendo então solicitadas suas considerações finais sobre o CBH Tietê - Jacaré ou sobre gestão de recursos hídricos em geral.

Para facilitar a transcrição das respostas e sua análise, estava prevista gravação digital das entrevistas, porém foi constatado que o gravador provocou inibição nos entrevistados, tendo sido inclusive solicitado que se 
desligasse 0 gravador em parte da entrevista. Por esse motivo, optou-se por não mais utilizar o gravador, mas sim prosseguir somente com as anotações das entrevistas.

\subsubsection{Aplicação dos demais questionários}

Pela programação inicial, este questionário deveria ser aplicado por esta pesquisadora pessoalmente ou, quando esse contato não fosse possível, seria utilizado telefone. Na prática, porém, a alternativa de telefone não foi aplicada. Em alguns casos, geralmente por dificuldade de disponibilidade do tempo necessário para a entrevista, os membros se ofereceram para responder o questionário por escrito e enviar por correio eletrônico. Para estes casos, foram feitas pequenas alterações no questionário enviado visando uma melhor compreensão (Anexo 11.5). Algumas questões foram mais bem explicadas e acrescentaram-se alternativas para escolha em algumas delas. Foi enviado em anexo um resumo da pesquisa, conforme Anexo 11.3, para melhor compreensão do entrevistado. Esse resumo também foi mostrado a alguns entrevistados que não haviam participado da reunião plenária de junho, quando houve a apresentação da pesquisa.

As entrevistas foram agendadas pela pesquisadora ou por intermédio de membros do comitê. Somente nos casos em que tal agendamento não foi possível, mesmo após várias tentativas de contato, o questionário foi enviado por correio eletrônico junto com texto de apresentação da pesquisa (ver Anexo 11.3). O envio para resposta por escrito não foi apresentado como preferencial devido à dificuldade de se obter explicações maiores e comentários sobre as diversas situações abordadas. Nos casos em que não foi possível entrevistar os membros titulares, seus suplentes foram contatados para aplicação do questionário. 
Nos municípios que apresentaram grande dificuldade para a realização da entrevista diretamente com os prefeitos, optou-se pela realização de entrevistas com representantes da prefeitura ligados ao assunto, frequentadores das reuniões do comitê e, quando possível, participantes de câmaras técnicas. Nestes casos, foi solicitado que as respostas abrangessem a visão da prefeitura sobre os assuntos ou, quando possível, a visão do prefeito. Nas questões sobre atuação pessoal, procurou-se levantar informações sobre a participação do prefeito, mesmo quando obtidas respostas junto a outro entrevistado.

Em maio de 2010, a lista de representantes da gestão 2009 - 2011 foi fornecida pela secretaria executiva, onde constavam informações referentes a duas alterações recentes no quadro de representantes, ainda sem a devida atualização no site do comitê. Durante tentativas de contato, esta pesquisadora obteve informações, junto aos representantes listados, sobre mais três substituições, resultando assim a lista de representantes constante no Anexo 11.2.

Apesar do esforço para contato, não foi possível o agendamento com todos os membros do comitê. Devido às dificuldades de contato, foram enviadas mensagens a todos os representantes que ainda não haviam sido entrevistados, com o questionário e com o texto de apresentação da pesquisa, solicitando o preenchimento, completando-se assim, em dezembro de 2010, o universo escolhido.

\subsubsection{Participação em reuniões do comitê}

Além da participação na reunião plenária do comitê no dia 28 de junho, quando foi feita a apresentação da pesquisa, esta pesquisadora participou de três reuniões do comitê visando um maior entrosamento com os 
participantes e um maior conhecimento, tanto dos assuntos tratados neste colegiado, como do processo de tomada de decisão. Foram elas:

- Reunião da Câmara Técnica de Educação Ambiental - em 28 de julho de 2010 - na FATEC, em Jaú;

- Reunião conjunta das Câmaras Técnicas - em 30 de novembro de 2010 - na FATEC, em Jaú; e

- Reunião Plenária - em 10 de dezembro de 2010 - no Auditório da Câmara Municipal de Itaju.

\subsection{ANÁLISE DOS RESULTADOS}

O questionário, primeiramente apresentado em 5 blocos, foi reclassificado conforme a nova separação temática, seguindo as categorias de análise apresentadas no quadro 1 , do Capítulo 6 , a saber:

- Informações sobre os representantes (Identificação e Perfil)

- Participação dos envolvidos

- Condições de participação dos membros no comitê

- Composição dos comitês

- Representatividade da entidade

- Representatividade do representante

- Capacitação técnica em recursos hídricos

- Informação e comunicação aos envolvidos

- Estabelecimento do Plano de Bacia

- Estabelecimento da Cobrança pelo uso da água

- Resultado final

As respostas aos questionários foram transcritas para arquivos de texto e sua análise realizada de duas formas distintas. 
As questões fechadas, que envolviam múltipla escolha ou respostas que possibilitaram a distribuição por alternativas, foram catalogadas em planilhas desenvolvidas no software Microsoft Excel para possibilitar a tabulação de todos os dados, cruzamentos de informações levantadas, sua análise estatística e a construção de tabelas e gráficos.

As informações obtidas por meio de questões dissertativas, ou ainda em complementação às questões fechadas, em alguns casos muito ricas e extensas, foram avaliadas separadamente e agrupadas por similaridade, por meio da classificação segundo as categorias e os aspectos em análise.

Os resultados obtidos nas entrevistas estão apresentados no item 7.6. Tais resultados foram avaliados em conjunto com os materiais coletados nas fases anteriores e estão apresentados no item 7.7.

Levando-se também em consideração os referenciais teóricos obtidos na pesquisa bibliográfica e a experiência desta pesquisadora, obtida por meio da participação em outros colegiados do SIGRH, foram elaboradas as Conclusões apresentadas no Capítulo 8 e as Recomendações Finais, no Capítulo 9. 


\section{GESTÃO DE RECURSOS HÍDRICOS}

O uso de recursos hídricos sem planejamento e controle adequados ocasionou grande impacto à saúde e ao ambiente no mundo todo. Para que este fato não seja agravado no futuro, com prejuízos ainda maiores à saúde pública, a gestão dos recursos hídricos vem sendo estudada de maneira especial e tem sido foco de grandes eventos mundiais que causaram alterações significativas nos conceitos e princípios de gestão adotados até então. Segundo LINSLEY e FRANZINI (1978), "a década de 1960 será lembrada como um período de aumento de preocupação com o meio ambiente" (p. 739) e, com ele, um dilema para os engenheiros responsáveis por obras de recursos hídricos: cessar todas as construções ou prosseguir rapidamente com as obras. O desenvolvimento urbano, sem planejamento ambiental adequado, tem causado grandes prejuízos à sociedade.

Este capítulo se inicia com uma abordagem sobre os aspectos conceituais da gestão de recursos hídricos. Para melhor entendimento das pressões exercidas pelo movimento ambiental global e suas repercussões na gestão de recursos hídricos no mundo, apresenta informações e resultados dos principais fóruns mundiais sobre água e meio ambiente. Em seguida, relata três casos de estudo sobre experiências bem sucedidas de gestão de recursos hídricos em países desenvolvidos, que influenciaram definições políticas em diferentes regiões do mundo. Devido à importância do tema para esta pesquisa, discute separadamente os aspectos ligados à participação dos diferentes atores na gestão de recursos hídricos. Por último, enumera as lições aprendidas deste material, em especial por meio das experiências internacionais, que subsidiaram a construção do atual sistema brasileiro de gerenciamento de recursos hídricos. 


\subsection{ASPECTOS CONCEITUAIS DA GESTÃO DE RECURSOS HÍDRICOS}

Gestão de Recursos Hídricos, segundo BARTH (1987), "é a forma pela qual se pretende equacionar e resolver as questões de escassez relativa dos recursos hídricos" (p. 12), e é realizada por meio de procedimentos integrados de planejamento e de administração, condicionados à motivação política para a sua efetiva implantação.

Entende-se por planejamento de recursos hídricos "o conjunto de procedimentos organizados que visam ao atendimento das demandas de água, considerada a disponibilidade restrita desse recurso" (BARTH, 1987, p.12). Abrangem a avaliação prospectiva das demandas e das disponibilidades dos recursos hídricos e a sua alocação entre os diversos usos para se obter os benefícios econômicos e sociais esperados. Devido ao tempo de maturação e da vida útil das obras hidráulicas, como também à irreversibilidade de muitas delas, os planos de recursos hídricos devem conter programas e projetos a curto, médio e longo prazos.

Administração de recursos hídricos é "o conjunto de ações necessárias para tomar efetivo o planejamento, com os devidos suportes técnicos, jurídicos e administrativos" (BARTH, 1987, p. 12-13).

Uma das atividades de planejamento de recursos hídricos é o encaminhamento político - institucional, que engloba a elaboração e projeto dos instrumentos e mecanismos técnicos, econômicos, financeiros e institucionais necessários para a administração do plano; treinamento e capacitação de pessoal necessário à execução do plano; e comunicação e divulgação social (BARTH, 1987).

Planejamento adequado e administração cuidadosa dos recursos hídricos são essenciais para se atingir a eficiência na utilização da água. Para isso, 
além da adoção de conceitos de engenharia, é necessário abordar aspectos econômicos, sociais e políticos (LINSLEY e FRANZINI, 1978). Devido aos diferentes atributos e às peculiaridades dos recursos hídricos, sua gestão exige esforços de coordenação multidisciplinar e intersetorial e devem ser considerados, de forma integrada e harmônica, os princípios básicos referentes ao ciclo hidrológico, à qualidade da água, aos aproveitamentos da água e ao controle da água (BARTH, 1987).

No tocante à capacitação dos profissionais envolvidos com gestão de recursos hídricos, TUCCI (2003) afirma:

"O desenvolvimento dos recursos hídricos não pode se desassociar da conservação ambiental, já que na essência envolve a sustentabilidade do homem no meio natural. $O$ ensino e a ciência têm sido por demais disciplinares e, ao longo do século passado, formaram profissionais com delimitações geradas pela compartimentalização do conhecimento em profissões voltadas para ações dentro de um sistema muito limitado, como, por exemplo, o projeto de uma estação de tratamento de água e a drenagem de um loteamento. O século XXI tem por paradigma a ação de um sistema mais complexo em que todos os componentes que o afetam sejam tratados na busca da sustentabilidade como a visão integrada dos recursos hídricos e o meio ambiente.

Para desenvolver esses princípios é necessário abrir a mente de engenheiros, geólogos, biólogos, agrônomos, economistas, advogados, geralmente influenciados pela tradicional delimitação do conhecimento em razão de sua formação“ (p. xv).

Ao observar as experiências internacionais de gestão das águas, GRISOTTO (2003) lista cinco características comuns aos diversos países que podem ser adotadas como referenciais norteadores ao gerenciamento dos recursos hídricos. São elas:

- "Definição de uma base territorial de gestão, geralmente a bacia hidrográfica;

- Organização comunitária com a finalidade de participação na gestão;

- Estabelecimento de instrumentos regulatórios, econômicos, de disciplinamento e penalização; 
- Mecanismos de instrumentação técnica dos sistemas, como planejamento e fluxo de informações; e

- Definição institucional da unidade regional, dos gerenciadores e usuários como co-responsáveis pela gestão“ (p. 7).

Além destes norteadores, MIYASHITA (1998) cita a necessidade do estabelecimento da gestão da água nos níveis nacional, regional e local, reforçando assim o princípio da descentralização da gestão e o papel do comitê de bacia hidrográfica, responsável pela coordenação e planejamento de ações em cada bacia.

Dentre os instrumentos econômicos, destaca-se a adoção da cobrança pelo uso da água, instrumento já adotado em vários países, seguindo os princípios do usuário-pagador e do poluidor-pagador. Dentre os países onde este instrumento foi adotado, THAME (2000) ressalta o caráter de instrumento de gestão, e não somente de um simples instrumento arrecadatório, ao destacar duas experiências:

- $\quad \mathrm{Na}$ França, cuja gestão de recursos hídricos será tratada no item 4.3.1, a cobrança foi aceita com naturalidade nas regiões onde a situação dos recursos hídricos era mais crítica, as quais, por disporem de recursos para reverter mais rapidamente a situação de escassez nelas encontradas, serviram de exemplo para que as demais adotassem também a cobrança; e

- No México, o montante arrecadado pela captação de água que, no início da cobrança, era igual ao montante referente à poluição das águas passou a representar apenas $10 \%$ do total após variações nos valores cobrados ao longo dos anos, penalizando os poluidores.

Ao analisar as interfaces entre a gestão urbana e regional com 0 gerenciamento de recursos hídricos, LEAL (2003) reforça a necessidade do "reconhecimento da água como um bem precioso, de valor inestimável, essencial a todas as formas de vida e fundamental às atividades humanas e ao desenvolvimento sócio-econômico" (p. 83). 
Dentre as principais recomendações resultantes dos fóruns globais, cabe ainda ressaltar a importância da formulação de políticas nacionais de água articuladas com as demais políticas setoriais do país, como do meio ambiente, da agricultura e do uso do solo. Estas políticas deverão estar consubstanciadas em "normas jurídicas, planos e programas que revelem o conjunto de intenções, decisões, recomendações e determinações de governo quanto à gestão dos recursos hídricos" (BARTH, 1987, p. 15).

\subsection{FÓRUNS GLOBAIS SOBRE RECURSOS HÍDRICOS}

As questões relacionadas à poluição das águas começaram a ser tratadas como uma preocupação global durante a Conferência das Nações Unidas sobre o Meio Ambiente, realizada em Estocolmo, na Suécia, em junho de 1972.

Segundo GODOY (2007), esta Conferência, que contou com a participação de representantes de 113 países, foi o primeiro grande encontro internacional voltado para a discussão dos problemas ambientais e da relação entre desenvolvimento e meio ambiente. Um documento histórico com 24 artigos foi gerado e um de seus principais desdobramentos foi a criação do Programa das Nações Unidas para o Meio Ambiente (PNUMA), a primeira agência ambiental global.

A preocupação ambiental se manteve durante a Conferência das Nações Unidas sobre a Água, realizada em Mar del Plata, na Argentina, em março de 1977. Ao ressaltar a importância de uma maior atenção ao planejamento integrado do uso da água, foi levantada a necessidade de serem formuladas políticas nacionais de água em alguns países compatíveis com as políticas econômicas e sociais gerais do país, visando uma melhoria da qualidade de vida da população. Foi também recomendada a adoção de medidas para possibilitar a participação efetiva 
do público no processo de planejamento e tomada de decisões, englobando usuários e autoridades públicas (CEPAL, 1998).

Tais discussões se acentuaram durante a Conferência Internacional sobre a Água e o Meio Ambiente: o Desenvolvimento na Perspectiva do Século XXI, realizada em janeiro de 1992 em Dublin, na Irlanda, como um dos eventos preparatórios para a $2^{\text {a }}$ Conferência das Nações Unidas sobre 0 Meio Ambiente e o Desenvolvimento. Neste evento foram formulados quatro princípios norteadores para a gestão da água, relatados a seguir:

"Princípio no 1 - A água doce é um recurso finito e vulnerável, essencial para sustentar a vida, o desenvolvimento e o meio ambiente;

Princípio no 2 - O aproveitamento e a gestão da água deverão ser baseados numa abordagem participativa, envolvendo os usuários, os planejadores e os responsáveis pelas decisões em todos os níveis;

Princípio $n^{0} 3$ - A mulher desempenha um papel fundamental no abastecimento, na gestão e na proteção da água; e

Princípio no 4 - A água tem um valor econômico em todos os seus usos competitivos a que se destina e deve ser reconhecida como um bem econômico "(CEPAL, 1998, p. 49 - tradução nossa).

Para se alcançar um gerenciamento mais eficiente dos recursos hídricos, os participantes ressaltaram a necessidade do estabelecimento de arranjos institucionais nas esferas local, nacional e internacional com o comprometimento dos governos, levando-se em consideração tais princípios. Mostrou-se a importância da participação dos usuários, dos planejadores e dos legisladores no sistema de gestão; de uma sensibilização baseada em programas efetivos de informação, capacitação e comunicação dos envolvidos na implementação de tais arranjos; e da adoção da bacia hidrográfica como entidade geográfica para a gestão dos recursos hídricos. Foi também evidenciada a recomendação para a realização de ações coordenadas visando a reversão das tendências existentes de desperdício, poluição e crescente ameaça de enchentes e secas (CEPAL, 1998; PIO, 2005; RAMOS, 2007). 
Em junho de 1992, aconteceu a $2^{\text {a }}$ Conferência das Nações Unidas sobre o Meio Ambiente e o Desenvolvimento, na cidade do Rio de Janeiro, no Brasil, cujos principais temas foram o desenvolvimento sustentável e a reversão do processo de degradação ambiental. A Rio 92, como ficou conhecida, mobilizou praticamente o mundo inteiro ao reunir cerca de 5000 delegados de 178 países (PIO, 2005). O principal documento assinado neste evento foi a Agenda 21 que, além de atender aos problemas prementes na época, tinha como objetivo preparar o mundo para o século XXI (PIO, 2000). No Capítulo 18, intitulado: Proteção da qualidade e do abastecimento dos recursos hídricos: aplicação de critérios integrados para o aproveitamento, manejo e uso dos recursos hídricos, foi destacada a importância da gestão integrada dos recursos hídricos através dos seguintes temas:

- Manejo e aproveitamento integrado dos recursos hídricos;

- Monitoramento dos recursos hídricos;

- Proteção dos recursos hídricos, da qualidade da água e dos ecossistemas aquáticos;

- Abastecimento de água potável e saneamento;

- A água e o desenvolvimento urbano sustentável;

- Água para a produção sustentável de alimentos e o desenvolvimento rural sustentável; e

- Impactos das mudanças climáticas nos recursos hídricos (CEPAL, 1998).

A Conferência Internacional sobre Água e Desenvolvimento Sustentável, promovida pela United Nations Educational, Scientific and Cultural Organizations (UNESCO), em Paris, na França, em março de 1998, reuniu 600 participantes de 84 países, além de representantes de organizações não-governamentais. Apesar de não ter acrescentado nada de relevante ao debate internacional sobre os recursos hídricos, foram 
reforçados os princípios já levantados nos eventos anteriores. Dentre os aspectos institucionais levantados, CEPAL (1998) e RIBEIRO (2008) destacam:

- Reforma da legislação dos países para adequá-los à gestão integrada de recursos hídricos;

- Importância da participação da sociedade civil na gestão da água em todos os níveis de gestão;

- Necessidade de priorização para melhorias na capacitação e na informação dos profissionais e dos usuários;

- Adoção da bacia hidrográfica como unidade de gestão; e

- Definição dos investimentos na bacia seguindo os princípios utilizador-pagador e poluidor-pagador.

Outras conferências e eventos aconteceram, dentre os quais destacam-se os quatro Fóruns Mundiais da Água, coordenados pelo Conselho Mundial da Água e realizados com periodicidade trienal entre 1997 e 2006 (RIBEIRO, 2008). As principais recomendações e inovações sugeridas nestas conferências vêm sendo incorporadas nos sistemas de gestão de recursos hídricos de diversos países, inclusive no Brasil, considerando-se as especificidades locais e a natureza dos problemas enfrentados.

\subsection{PRINCIPAIS EXPERIÊNCIAS INTERNACIONAIS NA GESTÃO DE RECURSOS HÍDRICOS}

Na década de 1970, vários países já haviam implantado sistemas de gestão, legislações, instituições e tecnologias de recursos hídricos como resposta às pressões exercidas sobre rios e cursos d'água pela poluição decorrente da industrialização, urbanização e agricultura crescentes. Tais "experiências tornaram-se paradigmas no debate internacional, destacando-se principalmente a Alemanha, a França, a Holanda, a 
Inglaterra, a Espanha, Israel e a experiência do Vale do Tennessee nos Estados Unidos" (CARDOSO, 2003, p. 17).

Cabe ressaltar o modelo francês por ser um dos primeiros países a adotar a cobrança pelo uso dos recursos hídricos, combinada a uma gestão participativa e integrada por bacia hidrográfica, e que serviu de modelo ao sistema empregado no Brasil e em outros países do mundo (RAMOS, 2007). Devido a essa influência, este modelo será descrito detalhadamente a seguir. Serão também apresentados sucintamente 0 modelo de gestão alemão e dois casos norte-americanos.

\subsubsection{Evolução da gestão de recursos hídricos na França}

As raízes do atual modelo francês de gestão de recursos hídricos remontam a 1964, ano em que foi criada a Lei das Águas - Lei o 64 1245, porém, apesar de existirem textos mais antigos, pode-se afirmar que a política da água na França nasceu no século XVI quando Luís XIV quis assegurar-se da possibilidade de construir e manter uma frota militar. "Foi nesta época que apareceram as Águas e Florestas e os serviços da Navegação" e a "dominialidade era pública" (BARRAQUÉ, 1995, p. 175). Depois, ainda na época do Império, a administração da água e outros assuntos coletivos passaram a ser confiados ao prefeito.

A partir da Lei de 9 de abril de 1898 começou a gestão comunitária das águas correntes, quando se buscava apresentar soluções setoriais a problemas específicos (ALVIM, 2003). A política centralizada no setor de recursos hídricos perdurou até os anos 1950, citando-se inclusive a promulgação de dois decretos-lei de 1935 que levou a reduções dos direitos dos proprietários sobre as águas subterrâneas e sobre as margens dos rios navegáveis (BARRAQUÉ, 1995). 
Com uma elevada capacidade de armazenamento natural de água e pouca dependência de recursos provenientes de países a montante (BARRAQUÉ, 1995), durante muito tempo os franceses julgaram que a água fosse um recurso inesgotável e sua única preocupação era universalizar o abastecimento de água potável e a coleta de esgotos (BORGES, 2008). No início dos anos 1960, a degradação dos corpos d'água começou a ser notada e os despejos urbanos e industriais foram apontados como os causadores (ALONSO, 2007). O crescimento acelerado da industrialização na França e o aumento das necessidades de irrigação na agricultura, além da maior preocupação com atividades de lazer e turismo, coincidiram com o início das preocupações ambientalistas na Europa, o que pôs em evidência a questão dos recursos hídricos e a necessidade de uma gestão racional. Foi então, instituída a primeira Comissão da Água para estudo da poluição das águas e, posteriormente, um comitê interministerial para estudar os conflitos relacionados à água.

A partir deste movimento, em 16 de dezembro de 1964 foi promulgada a Lei das Águas, considerada um grande marco na luta contra a degradação dos recursos hídricos (ALVIM, 2003). Segundo MIYASHITA (1998), as principais mudanças introduzidas na França por tal lei foram:

- Adoção da bacia hidrográfica como unidade de gerenciamento de recursos hídricos;

- Elaboração de um programa plurianual de ação na bacia, visando o aproveitamento racional integrado e a recuperação e conservação da quantidade e qualidade das águas, ajustado aos programas quinquenais de desenvolvimento do país;

- Equilíbrio orçamentário anual e autonomia financeira em cada bacia hidrográfica para aprovação de objetivos, metas, obras e serviços do seu programa plurianual;

- Cobrança direta dos usuários das águas da bacia, visando cobrir os custos de interesse comum necessários para fornecimento dos recursos hídricos disponíveis; 
- Instituição de um comitê para cada bacia hidrográfica, responsável pela coordenação e planejamento de ações em cada bacia, incluindo a aprovação do programa plurianual e dos valores a serem cobrados dos usuários da água; e

- Participação de diferentes segmentos da sociedade envolvidos com recursos hídricos, garantindo assim o comprometimento das bases nas decisões dos Parlamentos das Águas.

A França foi então dividida em seis zonas geográficas denominadas bacias hidrográficas e, em 1965, foram criados, para cada uma delas, um Comitê de Bacia Hidrográfica e uma Agência de Bacia - hoje Agência da Água.

Os Comitês de Bacia Hidrográfica, conhecidos como Parlamentos das Águas, foram formados por representantes de diferentes categorias de usuários da água (indústrias, agricultores, pescadores, associações de proteção à natureza, concessionárias de serviços de saneamento básico) e personalidades de notória experiência no assunto (como ex-ministros e técnicos renomados), representantes designados pelas comunidades locais componentes da bacia e representantes da administração nacional, em proporções iguais (NEDER, 2000). As Agências de Bacia são entidades públicas, dotadas de personalidade jurídica e autonomia financeira, que se relacionam estreitamente com os comitês. São responsáveis pelo suporte técnico e administrativo às ações na bacia e pelos mecanismos financeiros para mobilizar os fundos necessários (ALONSO, 2007). Apesar de seu caráter executivo, as agências não são responsáveis diretamente por construções e operação de obras, mas sim pelo planejamento e financiamento das ações de proteção e recuperação dos cursos d'água da bacia (RAMOS, 2007).

Foi também instituído um Comitê Nacional da Água, para coordenar a administração de recursos hídricos em nível nacional, em especial para 
tratar de questões entre comitês de bacia e de planos de desenvolvimento regional (MIYASHITA, 1998).

A grande importância desta lei se deve ao seu caráter inovador na medida em que reconheceu a necessidade de um controle mais sistemático da poluição e introduziu o conceito do poluidor-pagador, onde os usuários dos recursos hídricos são responsáveis pela arrecadação de parte dos fundos necessários para o tratamento dos despejos. Esta legislação e seus mecanismos de apoio financeiro permitiram, em 15 anos, multiplicar por cinco o número de estações de tratamento de esgotos em operação no país (ALONSO, 2007; BARRAQUÉ, 1995).

A autonomia financeira alcançada em cada bacia hidrográfica mostra que a água deixou de ser um recurso natural limitado e passou a representar um patrimônio público de valor econômico (NEDER, 2000).

Devido às pressões sociais e ao próprio amadurecimento do sistema francês, este sistema de gestão sofreu modificações e, em 1981, foi criado um novo instrumento de gestão em nível de cursos d'água: o contrato de rio. Trata-se de um programa de ação para 5 anos, com forte mobilização dos representantes locais e dos usuários, que envolve contratualmente os financiadores institucionais e os encarregados pelas obras (MAGALHÃES JÚNIOR, 2007; HUBERT et al., 2002).

Como a poluição dos rios voltou a crescer, agora provocada pela aplicação excessiva de produtos químicos na agricultura, nova legislação foi aprovada em 3 de janeiro de 1992 - a Lei № 92 - 3, cuja principal novidade foi a unificação do regime de todas as categorias de água sob a denominação de patrimônio comum da nação (ALONSO, 2007). Os instrumentos instituídos pela legislação de 1964, tais como cartas departamentais de objetivos de qualidade, planos diretores de águas e planos departamentais de vocação piscícola, não permitiam a realização 
de uma gestão global por várias razões: não tinham respaldo jurídico por terem sido instituídos por portarias ministeriais ou interministeriais; seu acatamento não era obrigatório pelas administrações públicas; sua elaboração era conduzida pelo Estado, com pouca associação dos demais atores; e tinham os limites de território, e não da bacia hidrográfica, como perímetro de aplicação (HUBERT et al., 2002).

Dentre as ferramentas de planejamento introduzidas pela nova legislação, destacam-se duas. A primeira delas, os chamados Planos Diretores de Ordenamento e de Gestão das Águas [Schéma Directeur de Aménagement et de Gestion des Eaux - SDAGE], tem sua elaboração sob a responsabilidade do comitê de bacia, cujo papel foi reafirmado pela nova lei, e devem conter as orientações para a gestão da água na bacia em um prazo de 15 anos (CAMPOS, 2001). A segunda ferramenta, os Planos de Ordenamento e de Gestão das Águas [Schéma de Aménagement et de Gestion des Eaux - SAGE], está sob responsabilidade das Comissões Locais da Água, cuja função é elaborar, revisar e acompanhar a realização destes planos segundo seus interesses e características dos problemas locais. Trata-se de um órgão de articulação entre os atores locais, que visa possibilitar a realização em conjunto de estudos e obras pelas coletividades territoriais interessadas e seus grupamentos inseridos no perímetro do plano. Tais comissões são formadas por representantes das coletividades territoriais e estabelecimentos públicos, por representantes dos usuários ribeirinhos, organizações sócio-profissionais e associações, e por representantes do Estado e de seus estabelecimentos públicos (MACHADO, 2003).

\subsubsection{Gestão de recursos hídricos na Alemanha}

A Alemanha adota outro modelo de gestão: o governo federal estabelece uma legislação nacional mínima e cabe aos estados ampliá-las para 
alcançar objetivos mais localizados. Isso gera formas de gestão variadas, não existindo assim um modelo nacional único, mas sim vários órgãos regionais e consórcios municipais também responsáveis pela gestão de recursos hídricos (CAVINI, 2009).

Uma das características da política de gestão e proteção dos recursos hídricos é a combinação de instrumentos de comando e controle, cabendo ao governo federal sua regulação e fiscalização, como também a aplicação da cobrança pelo uso dos recursos hídricos. Outro diferencial no modelo alemão é a cobrança feita por uma terceira forma. Além da cobrança pelo lançamento de cargas residuais, tratadas ou não, nos corpos hídricos e pela captação de águas superficiais e subterrâneas, há também a cobrança para o tratamento de água da chuva, com base nas áreas impermeabilizadas de cada imóvel (BORGES, 2008).

O atual sistema alemão de gestão da água, instaurado em 1957 e modificado em 1986, possibilita que a gestão da água e do saneamento fique a cargo das associações de gestão privadas, constituídas por proprietários de terra, empresas ou estabelecimentos públicos e sua atuação pode ocorrer sem respeitar os limites políticos tradicionais (MAGALHÃES JÚNIOR, 2007). Como há liberdade para constituição de associações de gestão da água no país, que podem ser formadas em função do tipo de problemas e das características locais, há, por toda a Alemanha, muitas associações de pequena dimensão responsáveis pelo gerenciamento local da água (RAMOS, 2007; CAVINI, 2009).

Uma das mais antigas agências de água do mundo nasceu em 1899, de adesão voluntária: trata-se da Associação das Barragens do rio Ruhr [Ruhrtalsperverrein], tributário do rio Reno, que foi objeto de legislação em 1913, quando foi transformada em entidade de direito público de adesão compulsória (MIYASHITA, 1998). Hoje, após várias alterações ao longo dos anos, a Associação de Águas do Ruhr [Ruhrverband] é composta por 
uma assembleia de associados formada por no máximo 152 delegados, um quadro supervisor com 5 membros e um quadro executivo com 10 membros (CAMPOS, 2001). Além do gerenciamento dos recursos hídricos da bacia e da operação dos reservatórios e controle de enchentes, cabem a ela a construção e a operação de todas as estações de tratamento de esgoto e das águas pluviais da bacia (RAMOS, 2007).

Este modelo se expandiu por outras áreas industriais na própria Alemanha e seus princípios também foram adotados por outros países.

4.3.3 Experiências em gestão de recursos hídricos nos Estados Unidos da América

O órgão responsável pela gestão de recursos hídricos nos Estados Unidos em âmbito nacional é o Conselho de Recursos Hídricos. No âmbito regional, porém, o perímetro hídrico utilizado pode ser a bacia hidrográfica, a região hidrográfica ou o grupo de bacias, possibilitando arranjos institucionais variados, como comissões federais interestaduais, associações interestaduais, comitês interagências de bacias hidrográficas ou agências federais regionais, como a Tennessee Valley Authority (TVA) (MIYASHITA, 1998).

Criada em 1933, a TVA atua no Vale do Tennessee, abrangendo total ou parcialmente sete estados distintos com predomínio de atividades agrícolas, atua com uma equipe interdisciplinar no controle e na utilização das águas para múltiplos fins visando o desenvolvimento da região. Os princípios adotados foram: gestão por bacia hidrográfica, participação da população e descentralização. Junto a isso, um fundo próprio e autonomia Ihe garantiram poder para realizar o programado. 
Segundo CAMPOS (2001), este modelo serviu de referência ao Brasil, pois na década de 1960 houve um intercâmbio de ideias e de recursos humanos e financeiros entre os dois países, e muitos profissionais brasileiros ligados a esta área formaram-se nos Estados Unidos.

Outro caso americano atual é o Sacramento Water Forum. Trata-se de um grupo com representantes de cerca de 40 organizações ambientais, empresariais, municipais e agrícolas, fundado pelo município e condado de Sacramento, que tem como objetivos garantir o abastecimento de água necessário ao desenvolvimento planejado para o ano de 2030 e preservar ambientalmente a bacia do Lower American River. Este grupo não é controlado por agência governamental e conta com um facilitador para garantir que todos sejam ouvidos, todos os assuntos sejam endereçados e todos os conflitos resolvidos (WATER FORUM, 2010). Foram necessários 5 anos para esse grupo construir a estratégia e os procedimentos para gerenciamento da limitada oferta de água da região semi-desértica do norte da Califórnia. Porém, em 1999, eles chegaram a um acordo baseado na colaboração de todos os envolvidos (INNES e BOOHER, 2000).

\subsection{ASPECTOS SOBRE PARTICIPAÇÃO SOCIAL NA GESTÃO DE RECURSOS HÍDRICOS}

ASSIS e SALVADOR (1998), ao iniciar um relato sobre a implantação do Sistema Integrado de Gerenciamento de Recursos Hídricos no Estado de São Paulo, apontam a democracia como "o objetivo maior e a razão fundamental que orienta as ações e os novos rumos da sociedade contemporânea" (p. 86) e lembram que:

"A democracia efetiva é hoje o paradigma fundamental que implica no desmembramento do poder. Por sua vez, diluir poder significa descentralizar as decisões e partilhá-las. Porém é preciso haver alguém 
com quem partilhar. É preciso que haja participação. Esse discurso não é novo; no entanto, sua concretização continua sendo um desafio“ (p. 86).

Os eventos ambientais promovidos pela Organização das Nações Unidas (ONU) a partir da década de 1970, já relatados no item 4.2, caminharam neste sentido e provocaram mudanças radicais nos sistemas de gerenciamento de recursos hídricos de diversos países. Uma das recomendações resultantes da Conferência de Mar del Plata, realizada em 1977, diz respeito à participação do público. Ao reconhecer que, quando se tomam decisões, deve-se levar em conta a opinião de quem será afetado por elas, recomendou-se que:

"Os países devem fazer os esforços necessários para adotar medidas que permitam obter a participação efetiva do público no processo de planejamento e tomada de decisão que englobem os usuários e as autoridades públicas. Essa participação pode influir construtivamente na elaboração de planos e políticas. Se necessário, a legislação deverá dispor essa participação como parte integrante do processo de planejamento, programação, execução e avaliação" (CEPAL, 1998, p. 34, tradução nossa).

Essa opinião é também defendida por AMARAL (1998), que afirma que:

"A questão da participação de usuários e poder público em políticas de gestão de recursos hídricos baseia-se na convicção de que a resolução de problemas complexos exige uma ampla compreensão dos valores, dos conhecimentos e dos interesses das partes afetadas e de que, apesar da incerteza, no médio e no longo prazos as decisões tomadas em comum acordo tendem a resultar em melhorias para o meio ambiente e em redução dos conflitos" (p. 8).

Para que isso seja possível, recomendou-se aos países a elaboração de dispositivos legislativos, programas educativos e atividades de participação para aumentar o conhecimento do público sobre o valor da água e os riscos de escassez provocada pelo seu uso abusivo; e o esforço para incentivar a participação pública como parte integrante do processo de tomada de decisão e de uma troca de informações ininterrupta (CEPAL, 1998). 
Nos fóruns mundiais seguintes essa recomendação foi reforçada, ressaltando ainda a necessidade de envolvimento dos planejadores e dos legisladores no sistema de gestão, e a importância da sensibilização, da capacitação e da comunicação dos envolvidos.

A Agenda 21, principal documento assinado durante a $2^{\text {a }}$ Conferência das Nações Unidas, realizada no Rio de Janeiro, em 1992, recomendou, em seu Capítulo 23, intitulado Fortalecimento do papel dos grupos principais, a ampla participação da opinião pública na tomada de decisão como um dos pré-requisitos fundamentais para alcançar 0 desenvolvimento sustentável. Dentre outras questões, isso inclui a necessidade de indivíduos, grupos e organizações terem "acesso à informação pertinente ao meio ambiente detida pelas autoridades nacionais, inclusive informações sobre produtos e atividades que têm ou possam ter um impacto significativo sobre o meio ambiente, assim como informações sobre medidas de proteção ambiental" (SMA, 2004, p. 51).

HOOPER (2006) aponta o acesso a dados e a oportunidade de participar nas tomadas de decisão como fatores chave para ganhar o apoio, o envolvimento e o comprometimento dos stakeholders no gerenciamento de recursos hídricos. O autor enfatiza que a ausência de transparência e de consulta à população local sobre as propostas para gerenciamento dos recursos hídricos pode provocar forte impacto à gestão, alimentando ressentimentos e conflitos entre os envolvidos.

Para que essa participação atinja os objetivos previstos, é imprescindível que tanto os representantes do governo quanto os da sociedade civil entendam e apliquem os princípios de gerenciamento integrado de recursos hídricos e de sustentabilidade. Para isso, "é necessário investir em atividades e programas de educação e de conscientização pública que atinjam diferentes setores da sociedade" (HOOPER, 2006, p. 14). Segundo GIARETTA et al. (2010): 
"A ausência destes cuidados pode levar a entendimentos distorcidos da situação ambiental local ou, na pior das hipóteses, desconhecimento total das informações necessárias para tomada de decisão, o que invalida a capacidade individual e coletiva da sociedade tomar decisões conscientes para melhoria de seu município e, principalmente, causar desmotivação da sociedade em participar destes espaços" (p. 7).

A capacitação e a mobilização do público em geral, segundo TUNDISI (2003), devem ser elaboradas em relação aos problemas locais de água, isto é, problemas econômicos, sociais e de saúde da população associados à água. Devem ser utilizados meios populares de comunicação. No Brasil, o meio de comunicação mais popular ainda é o rádio.

A disponibilização de informações sobre a situação real dos recursos hídricos, em especial dos mananciais, deve ser feita com grande transparência pelos sistemas públicos e privados. Nestes casos, TUNDISI (2003) lista diversos meios possíveis para a transmissão de informações, dos quais ressaltam-se seminários, publicações, audiovisuais, conferências de imprensa e reuniões de bairro e com associações de classe.

No modelo de gestão integrada de bacias hidrográficas, segundo ALVIM (2003), cabe ao comitê de bacia ou à entidade responsável pela gestão da bacia, a coordenação das diversas autoridades públicas e privadas atuantes nesta região. $\mathrm{Na}$ fase de planejamento, ao se fazer a avaliação das demandas frente às disponibilidades dos recursos hídricos e a alocação entre os diversos usos concorrentes, cabe ao comitê a mediação dos conflitos através da articulação com todos os envolvidos. É necessário o envolvimento de todos aqueles que partilham do recurso ou que possam vir a interferir na sua disponibilidade, e não somente daqueles que estão ligados diretamente ao gerenciamento de recursos hídricos ou do meio ambiente. Como requisitos deste modelo de gestão, a autora aponta "as negociações e acordos entre os atores envolvidos, a 
flexibilidade de participação e a busca de objetivos claros e transparentes, em prol da bacia como uma unidade territorial" (ALVIM, 2003, p. 42).

A importância da participação dos stakeholders também é apontada por HOOPER (2006) com o objetivo de buscar a negociação e a construção de parcerias, e de se evitar a marginalização de grupos de usuários. Como stakeholders a serem envolvidos, este autor enumera entidades governamentais, organizações comunitárias, industriais e comerciais, e outras organizações ou indivíduos com responsabilidade ou interesse na bacia. $O$ autor também ressalta a necessidade de se criar mecanismos para assegurar a participação, direta ou indireta, de grupos marginalizados, seja por questões econômicas, sociais ou culturais. Encontrados em várias sociedades, tanto em comunidades pobres em desenvolvimento, como em economias altamente desenvolvidas, o desafio está em garantir a estes grupos, não só o direito a serem ouvidos, mas também a terem suas solicitações atendidas. Nesta linha, ARNSTEIN (2009) afirma que "participação é a redistribuição de poder que permite aos cidadãos sem-nada, atualmente excluídos dos processos políticos e econômicos, a serem ativamente incluídos no futuro" (p. 1).

JACOBI et al. (2009) afirmam que:

"A lógica do colegiado permite que os atores envolvidos atuem, em princípio, tendo um referencial sobre seu rol, responsabilidade e atribuições, e facilita uma interação mais transparente e permeável no relacionamento entre os diferentes atores envolvidos - governamentais, empresariais e usuários" (p.75).

Ressalta-se aqui a importância da identificação de todos os atores envolvidos em cada bacia. Para o gerenciamento adequado da bacia hidrográfica, TUNDISI (2003) ressalta a importância da participação integrada de quatro segmentos: o setor privado, o setor público, os usuários e as universidades, cada qual com suas responsabilidades. Essa relação, porém, pode variar de bacia para bacia, não só em função das 
instituições e órgãos governamentais atuantes na região, como também em função das necessidades e dos problemas, existentes e em potencial.

Para a definição das entidades que deverão fazer parte dos colegiados deliberativos, é necessário listar inicialmente todos os stakeholders daquela bacia, através do levantamento dos atores que podem contribuir ao processo de tomada de decisão, das entidades necessárias para implementação das decisões, das entidades que possam bloquear decisões ou suas implementações, bem como de todos que possam ser afetados por tais questões (HARMONICOP, 2005). Para a formação do grupo participativo, dentre os fatores apontados pela equipe HARMONICOP (2005), constam "máxima diversidade de representação, boa vontade dos stakeholders para cooperar, e o número total de participantes, pois quanto menor o grupo, maior a chance de a aprendizagem ocorrer (e mais barato o processo)" (p. 15, tradução nossa).

Outra questão a ser considerada é a viabilidade quanto à disponibilidade de alguns representantes para a participação das atividades do colegiado, tanto em relação ao tempo despendido, quanto aos recursos financeiros necessários para as atividades e os deslocamentos. Caso um stakeholder não tenha meios para viabilizar sua participação, mas esta representa uma grande contribuição ao grupo, a equipe HARMONICOP (2005) sugere que sejam feitos arranjos especiais para assegurar essa participação. Sugere também que sejam avaliados reembolsos de despesas de viagem e também pagamento a profissionais especialistas. Porém, ao considerar uma compensação financeira aos membros do grupo como reconhecimento do valor dessa participação, os autores ressaltam o cuidado necessário para que tal medida não atraia participantes por razões diversas. 
Durante o processo decisório do enquadramento dos corpos d'água no semi-árido brasileiro, MEDEIROS et al. (2009) detectaram, além da importância da identificação dos atores sociais a serem convidados a fazer parte do processo, a necessidade de identificar estrutura políticoinstitucional para garantir espaço e peso às organizações e às instituições participantes, garantindo assim que um grupo não se sobreponha aos demais.

Neste sentido, ASSIS e SALVADOR (1998) constataram, durante a instalação dos comitês paulistas de bacia, que "às vezes é melhor haver um conflito sobre o qual todos exponham suas posições e lutem por elas, do que uma imposição camuflada em consenso pelo silêncio dos que não concordam. Os que se sentirem prejudicados podem não voltar a participar da atividade e ainda desacreditá-la publicamente" (p. 93). JACOBI e SINISGALLI (2009) ressaltam que a participação de diferentes atores "leva à explicitação dos conflitos em fórum adequado e dá visibilidade às dimensões sociais, econômicas e territoriais do uso da água, e possibilita equacionar esta questão de forma cooperativa" (p. 7).

É importante ter em mente que, nestes fóruns, o processo de negociação é mais demorado, porém as decisões tendem a ser mais sustentáveis por serem definidas em consenso (PORTO e PORTO, 2008). Tal pensamento também é defendido pela equipe HARMONICOP (2005) ao afirmar que "processos participativos de tomada de decisão geralmente levam muito mais tempo que a tomada de decisão unilateral por um gestor de recursos hídricos" (p. 7, tradução nossa), tempo este que inclui a identificação do problema e o planejamento das ações escolhidas para solucioná-lo. Entretanto, acrescenta-se que, nos processos participativos, esta diferença é recuperada na fase de implementação das ações, resultando geralmente em tempos de projeto menores que os necessários para os projetos definidos unilateralmente. 
ASSIS e SALVADOR (1998) também ressaltam que a institucionalização ou o estabelecimento por lei não é suficiente para garantir a legitimidade de uma instância colegiada, mas sim que "há legitimidade quando os que dela participam reconhecem seu papel e importância, e quando a sociedade se sente devidamente representada" (p. 93).

"A democracia participativa acontece quando Estado e Sociedade Civil cumprem suas funções e obrigações", apontam ROESLER e CENCl (2010, p. 5). Dentre elas, está a construção de valores coletivos e, em algumas situações, a renúncia aos interesses pessoais em benefício da comunidade. Para os autores, "a democracia exige conviver ao mesmo tempo, com o consenso e conflito, num processo de diálogo onde as partes não saiam derrotadas, mas prioridades comuns sejam identificadas" (p. 9). E "é nesse convívio, na relação com as diferenças que o entendimento e o conflito se relacionam e a construção de consensos se torna possível" (ROESLER e CENCI, 2010, p. 9).

GIARETTA et al. (2010) constatam que, apesar da participação ser um consenso em termos conceituais, "a sua prática sistemática, enquanto resultado de reflexão política e prática de cidadania, ainda é um processo a ser construído" (p. 12).

\subsection{LIÇÕES DA EXPERIÊNCIA INTERNACIONAL AO MODELO BRASILEIRO}

Este capítulo tratou de aspectos conceituais da gestão de recursos hídricos, dos principais fóruns globais sobre água e meio ambiente e das recomendações deles resultantes, das experiências de sucesso de três países na reestruturação de seus sistemas de gestão de recursos hídricos, e de aspectos relacionados ao processo participativo nesta gestão. As principais lições aprendidas deste material, que serviram de 
base para a construção do modelo atual de gestão de recursos hídricos adotado no Brasil, resumidamente, são:

1. Reconhecimento da água como um bem precioso, de valor inestimável, essencial a todas as formas de vida e fundamental às atividades humanas e ao desenvolvimento sócio-econômico;

2. Necessidade de formulação de políticas nacionais de água, compatíveis com as políticas econômicas e sociais gerais do país, estabelecendo arranjos institucionais nas esferas local, nacional e internacional com o comprometimento dos governos;

3. Sugestão da adoção da bacia hidrográfica como unidade de gestão;

4. Instituição de um comitê para cada bacia hidrográfica, responsável pela coordenação e planejamento de ações em cada bacia;

5. Importância da participação pública no processo de planejamento e tomada de decisões, em todos os níveis de gestão, englobando todos os atores envolvidos, tais como usuários, autoridades públicas, legisladores, planejadores, especialistas e entidades da sociedade civil;

6. Necessidade de capacitação dos profissionais envolvidos com gestão de recursos hídricos;

7. Sensibilização e conscientização públicas baseadas em programas efetivos de informação, transparência e comunicação de todos os envolvidos;

8. Estabelecimento de instrumentos técnicos, regulatórios, econômicos, de disciplinamento e penalização;

9. Importância da elaboração de um planejamento a curto, médio e longo prazos na bacia, visando o aproveitamento racional integrado e a recuperação e conservação da quantidade e qualidade das águas: e

10. Equilíbrio orçamentário anual e autonomia financeira em cada bacia hidrográfica para aprovação de objetivos, metas, obras e serviços do seu programa plurianual, seguindo os princípios de utilizador-pagador e poluidor-pagador. 


\section{GESTÃO DE RECURSOS HÍDRICOS NO BRASIL}

Para tratar da gestão de recursos hídricos no Brasil e, em especial, no Estado de São Paulo, faz-se necessário conhecer o histórico da organização institucional para o disciplinamento do uso das águas. Este capítulo se inicia com um breve relato da história da administração das águas no país, relacionando determinantes histórico-conjunturais e os arranjos institucionais encontrados no Brasil em seu passado recente, enfocando também aspectos específicos do desenvolvimento da gestão das águas no Estado de São Paulo. Em seguida, são apresentadas as políticas de recursos hídricos vigentes no país separadas em três partes: primeiramente, no item 5.2, a Política Nacional de Recursos Hídricos, instituída em 1997; no item 5.3 são abordados, de forma resumida, aspectos gerais das políticas estaduais anteriores à lei nacional; e, no item 5.4, com enfoque mais detalhado devido à importância para o tema deste trabalho, é apresentada a Política Estadual de Recursos Hídricos, instituída em São Paulo em 1991.

O item 5.5 apresenta a situação atual da gestão de recursos hídricos no país. Para facilitar esta apresentação, este item é dividido em três partes: informações sobre a implantação dos comitês de bacias hidrográficas de rios de domínio federal; a situação atual dos comitês de bacias hidrográficas de alguns estados do país; e a evolução dos comitês paulistas. Por fim, no item 5.6 estão apresentados os desafios a serem enfrentados para aprimoramento da gestão de recursos hídricos.

\subsection{HISTÓRICO DA GESTÃO DE RECURSOS HÍDRICOS NO BRASIL}

A preocupação do governo brasileiro com as águas, em relação ao uso racional e à proteção deste rico manancial, segundo PEREIRA (2008), vem desde a legislação colonial, iniciando-se com as Ordenações Filipinas, decretadas em 11 de janeiro de 1603, que instituíam dispositivos 
específicos sobre a gestão da água, e passando pelo Decreto 5407 , de 1904, que regulamentou a utilização da força hidráulica para geração de energia elétrica.

No início do século $X X$, a destinação principal da água no Brasil era a geração de energia elétrica, mas também já eram intensos os usos para abastecimento público e agricultura. Em 1901, foi inaugurada a primeira usina da empresa canadense The São Paulo Tramway Light \& Power Company: a Usina de Parnahyba, hoje denominada Edgard de Souza. Os usos atendiam a interesses privados, no caso de indústrias e propriedades agrícolas; interesses privados motivados pelo poder público, como no caso da Light, empresa privada canadense contratada para geração de energia elétrica; e interesses públicos, nos casos de abastecimento das cidades. A concessão para tais usos era atribuição dos estados e dos municípios e ainda não se configuravam conflitos entre as diversas utilizações (BARTH, 1999).

Segundo MAGALHÃES JÚNIOR (2007), o início da institucionalização da gestão da água no Brasil pode ser associado à criação, em 1920, da Comissão de Estudos de Forças Hidráulicas, ligada ao Ministério da Agricultura, Indústria e Comércio. Em 1933, foi criada a Diretoria de Águas, depois transformada em Serviço de Águas, também no Ministério da Agricultura (BORSOI e TORRES, 2010). Esse serviço foi transferido para o Departamento Nacional de Pesquisa Mineral (DNPM) no ano seguinte, quando foi instituído o Código de Águas, através do Decreto 24643, de 10/07/1934. Esse documento, apresentado originalmente ao Congresso Nacional em 1907, representou o marco inicial para a gestão das águas no Brasil, pois embasou, com seus mecanismos institucionais e econômico-financeiros, a formulação de princípios voltados aos usos múltiplos e relacionou a questão da saúde pública e manutenção da qualidade das águas (GRISOTTO, 2003). As águas passaram a ser de 
domínio público de Municípios, de Estados ou da União, ou de domínio particular, nos casos de nascentes (LOPES e FREITAS, 2007).

O Código de Águas foi considerado muito avançado para a época por trazer conceitos inovadores, tais como: proibição de poluição da água e regras sobre as águas nocivas; possibilidade de pagamento pelo uso da água, tanto pela captação quanto pela poluição causada; aproveitamento das águas, navegação, derivações, prioridade para abastecimento público; concessão administrativa para as águas públicas; relações com o solo, sua propriedade e desapropriação; fiscalização, concessões, autorizações e aplicação de penalidades. Apesar do aspecto inovador e abrangente, sua regulamentação limitou-se ao desenvolvimento do setor elétrico, sem que se regulamentasse as outras questões relativas à gestão integrada dos recursos hídricos (BARTH,1999; GRANZIERA, 2001; MAGALHÃES JÚNIOR, 2007).

Segundo BARTH (1999), esse documento, ao passar a concessão dos aproveitamentos hidroelétricos e dos serviços de distribuição de energia elétrica para o âmbito da União, "se constitui no marco regulatório fundamental para o setor de energia elétrica, ao proporcionar os recursos legais e econômico-financeiros para a notável expansão do aproveitamento do potencial hidrelétrico que ocorreu nas décadas seguintes" (p. 565).

Esse período da administração dos recursos hídricos no Brasil foi denominado modelo burocrático, pois foi marcado pelo grande número de dispositivos legais sobre águas, com vasta legislação a ser obedecida referente a concessões e autorizações de uso, licenciamento de obras, ações de fiscalização, interdição e multas. Para BORSOI e TORRES (2010), as principais características deste período foram a centralização do 
poder decisório, o excesso de formalismo e a baixa importância dada ao ambiente externo.

A partir desta data surgiram outras legislações tratando isoladamente os diferentes usuários da água, em especial os sistemas energético, de saneamento e de irrigação. Em 1939, foi criado o Conselho Nacional de Águas e Energia Elétrica (CNAEE), diretamente ligado à Presidência da República; em 1960, o DNPM passou a integrar o Ministério das Minas e Energia, criado neste ano; em 1965, foi criado o Departamento Nacional de Águas e Energia (DNAE), que foi transformado em Departamento Nacional de Águas e Energia Elétrica (DNAEE) em 1968. Este órgão, marcado pela forte centralização imposta pelos governos militares, era responsável pela administração das estações hidrológicas federais e pelo armazenamento dos dados e, segundo BARTH (1999), consolidou a predominância do setor de energia elétrica na gestão das águas.

No Estado de São Paulo, em 1951, foi criado o Departamento de Águas e Energia Elétrica (DAEE), "voltado para o aproveitamento múltiplo e integrado dos recursos hídricos e com o objetivo de capacitar o Estado de São Paulo na produção de energia" (SMA, 1995, p. 11) e, em 1966, com a unificação de 11 empresas elétricas regionais, foi criada a Companhia de Eletricidade de São Paulo.

Na vertente do saneamento, em 1940, foi criado o Departamento Nacional de Obras e Saneamento (DNOS); e, no Estado de São Paulo, foi instituído o Fundo Estadual de Saneamento Básico (FESB) em 1968. Em 1971, foi implantado o Plano Nacional de Saneamento Básico (PLANASA), que provocou a criação de companhias de saneamento básico em todos os estados, aumentando assim o peso dos setores de abastecimento de água e de saneamento básico na agenda pública nacional. Com isso, para MAGALHÃES JÚNIOR (2007), os setores elétrico e de saneamento 
passaram a ser os dois pilares das políticas públicas federais sobre os recursos hídricos.

Esta segunda etapa da gestão dos recursos hídricos do país, denominada modelo econômico - financeiro, ficou marcada pelos programas de investimentos voltados às prioridades setoriais do governo. Apesar de possibilitar a realização do planejamento estratégico da bacia e a canalização de recursos financeiros para a implantação de investimentos planejados, esse sistema não conseguiu alcançar a utilização social da água e persistiram os conflitos entre os setores usuários (BORSOI e TORRES, 2010).

Em 1972, a preocupação global com as questões ambientais, em especial com a poluição das águas, ganhou evidência com a realização da Conferência das Nações Unidas, em Estocolmo, conforme relatado no item 4.2. No ano seguinte, como resposta à questão diplomática criada devido à posição do Brasil em Estocolmo, quando enfatizou o crescimento econômico em detrimento da preservação ambiental, foi criada a Secretaria Especial do Meio Ambiente (SEMA), subordinada ao Ministério do Interior. Primeiro órgão ambiental em nível federal, sua atuação na área de recursos hídricos se restringiu às questões referentes ao combate à poluição ambiental e, em uma época marcada pela desarticulação institucional, não se aproximou ao DNAEE, mesmo durante o estabelecimento do enquadramento das águas federais, em 1976 (SMA, 1995; MAGALHÃES JÚNIOR, 2007).

Um grande exemplo de ação de integração intergovernamental e interinstitucional, ressaltado por BARTH (1999), foi o acordo celebrado entre o Ministério das Minas e Energia e o Governo do Estado de São Paulo, em 1976, para o desenvolvimento de obras de saneamento, abastecimento de água e tratamento e disposição de esgotos, visando a 
melhoria das condições sanitárias nas bacias dos rios Tietê e Cubatão. Este acordo possibilitou a criação de comitês com participação de órgãos e entidades do Governo Federal e do Estado e da concessionária Light, atuantes nestas bacias. Com base nesta primeira experiência de gestão compartilhada entre a União e os estados, foram criados, em 1978, o Comitê Especial de Estudos Integrados de Bacias Hidrográficas (CEEIBH) e comitês executivos em bacias hidrográficas de domínio federal vinculados a ele. Além das funções de classificação dos cursos d'água da União, desenvolvimento do estudo integrado da utilização racional dos recursos hídricos federais, e acompanhamento desta utilização, o CEEIBH foi responsável pela articulação da gestão da água com a gestão ambiental, integrando órgãos federais, como SEMA, DNAEE, Departamento Nacional de Obras contra a Seca (DNOCS) e as Superintendências de Desenvolvimento Regional, com as Secretarias Estaduais do Meio Ambiente (MAGALHÃES JÚNIOR, 2007).

Foram criados comitês executivos em dez bacias de rios de domínio da União, dentre elas:

- Paraíba do Sul, abrangendo os estados de Minas Gerais, São Paulo e Rio de Janeiro;

- Paranapanema, abrangendo áreas do Paraná e de São Paulo;

- Grande, abrangendo São Paulo e Minas Gerais;

- Ribeira de Iguape, envolvendo Paraná e São Paulo; e

- São Francisco, nos estados de Minas Gerais, Bahia, Sergipe, Alagoas e Pernambuco.

Apesar de terem apenas atribuições consultivas, sem respaldo legal, constituíram-se em experiências importantes para a evolução da gestão de recursos hídricos no país, em especial o atuante Comitê Executivo de Estudos Integrados da Bacia Hidrográfica do Rio Paraíba do Sul 
(CEEIVAP). Após a priorização das ações necessárias nas respectivas bacias, muitos deles buscaram a viabilização destas ações junto aos próprios órgãos e entidades neles representados (MAGALHÃES JÚNIOR, 2007). Como aspectos negativos, é necessário apontar sua formação exclusivamente por membros do poder público, com maior peso da União, e sem participação do Município, e a ausência de estrutura técnicoadministrativa e financeira.

As discussões cresceram nos anos seguintes, conduzidas especialmente pelos Ministérios das Minas e Energia e do Interior. Este último passou a ser responsável pelo uso dos recursos hídricos para a irrigação a partir de 1979, com a promulgação da Lei № 6662, que estabeleceu a Política Nacional de Irrigação (BARTH, 1999). Por ser o único setor que criava demanda por regulação e que detinha todas as informações disponíveis sobre água, o setor de energia assumiu o papel de gestor dos recursos hídricos (BORSOI e TORRES, 2010). Mais uma vez observa-se o tratamento e a normatização de um aspecto da água de maneira isolada, não se levando em conta o meio ambiente como um todo, nem a água sob uma perspectiva de gestão integrada (SMA, 1995).

Em 1983, segundo GRISOTTO (2003), esse debate foi ampliado durante o "Seminário Internacional de Gestão de Recursos Hídricos, ocorrido em Brasília, que contou com a participação de especialistas da França, Alemanha e Inglaterra" (p. 21) e resultou na elaboração de documentos e recomendações sobre necessidade de sistemas de gerenciamento de recursos hídricos que influenciaram a elaboração das novas constituições, tanto a federal, como as de alguns estados brasileiros.

Neste mesmo ano, em São Paulo, foi criado o Conselho Estadual do Meio Ambiente (CONSEMA), composto por representantes da sociedade civil organizada e por membros do governo estadual, com a atribuição de 
assessorar o governador nos assuntos relativos a meio ambiente. Em 1985, o DAEE implantou um modelo de gestão descentralizada por bacias hidrográficas, a partir da criação de sete diretorias de bacias (OLIVI, 2004).

Em novembro de 1987, durante o VII Simpósio Brasileiro de Recursos Hídricos e Hidrologia, realizado em Salvador, promovido pela Associação Brasileira de Recursos Hídricos (ABRH), foi realizada mesa redonda onde foram abordados os aspectos políticos do gerenciamento de recursos hídricos e a criação da Comissão de Gestão. Na seção de encerramento deste evento, foi aprovada a Carta de Salvador para divulgação pública. Seus principais temas foram: a importância do uso múltiplo e integrado dos recursos hídricos; a descentralização do processo decisório e a participação das comunidades envolvidas; a necessidade de institucionalização de um sistema nacional de gestão de recursos hídricos com participação dos diversos níveis de governo; e, em especial, a formulação de uma política nacional de recursos hídricos, com planos, programas e normas jurídicas necessários BARTH (1999).

Para uma melhor compreensão do quadro instituído no país nesta época, MAGALHÃES JÚNIOR (2007) constata que:

"O Brasil situava-se em um contexto global de convergência de fatores que contribuiu para uma mudança nos rumos do tratamento da questão ambiental no país: o fim das ditaduras militares, as pressões ambientalistas nos níveis nacional e internacional, as novas discussões sobre desenvolvimento e gestão sustentáveis e a própria intensificação dos problemas ambientais no país" (p. 127).

A Constituição Federal de 1988 trouxe uma profunda alteração em relação às Constituições anteriores, caracterizando a água como um recurso econômico, como um bem exclusivamente de domínio público da União ou dos Estados, e considerando a necessidade de uma política integrada entre os corpos d'água e as terras que os circundam (PEREIRA, 2008). Instituiu para isso a bacia hidrográfica como base para a gestão das águas 
e o Sistema Nacional de Gerenciamento de Recursos Hídricos (SINGREH). Dentre os diversos aspectos introduzidos pela Constituição, que representou uma visão moderna sobre a administração dos recursos hídricos, estabeleceu-se que a competência para legislar sobre água é privativa da União, embora a competência para registrar, acompanhar e fiscalizar as concessões de uso de recursos hídricos seja comum, isto é, da União, Estados, Municípios e Distrito Federal (BORSOI e TORRES, 2010).

Diversas tratativas aconteceram no país objetivando a criação deste sistema de gestão. Uma delas foi o prosseguimento da discussão dos aspectos institucionais do gerenciamento de recursos hídricos durante o VIII Simpósio Brasileiro, promovido pela ABRH em 1989, que produziu a Carta de Foz de Iguaçu, com grande repercussão no meio técnico (PORTO e PORTO, 2008). Segundo BARTH (1999), o documento aprovado em Foz de Iguaçu, apresenta quatro princípios básicos:

- O gerenciamento dos recursos hídricos deve ser integrado, sem dissociação dos aspectos quantitativos e qualitativos;

- A unidade geográfica básica a ser adotada é a bacia hidrográfica;

- A água é um recurso econômico de expressivo valor e seus usos, tanto para captação quanto para diluição de esgotos lançados, devem estar sujeitos à cobrança; e

- A outorga de direito de uso, instrumento necessário para conciliar os usos múltiplos, deve ser de responsabilidade de um único órgão.

Outra ação foi a criação, em 1990, pelo governo federal, de um grupo de trabalho com a atribuição de estudar a gestão e a administração dos recursos hídricos no país e propor medidas visando ao estabelecimento da política integrada e do sistema nacional de gerenciamento de recursos hídricos (MAGALHÃES JÚNIOR, 2007). 


\subsection{POLÍTICA NACIONAL DE RECURSOS HÍDRICOS}

Segundo BORSOI e TORRES (2010), com a promulgação da Constituição de 1988 foram criadas as condições para se iniciar a terceira etapa da gestão de recursos hídricos brasileira, denominada modelo sistêmico de integração participativa que, além de estar voltado ao crescimento econômico, também visa a equidade social e o equilíbrio ambiental.

Em 8 de janeiro de 1997, após um longo período de tramitação no Congresso Nacional, a Política Nacional de Recursos Hídricos foi instituída através da Lei Federal oㅜ 9433. Trata-se de um instrumento legal de suma importância para a tutela das águas no Brasil, pois apresenta os dispositivos necessários para o controle, o uso e a proteção de um dos bens mais preciosos e essenciais à qualidade de vida da população (PEREIRA, 2008). Regulou o setor de recursos hídricos de forma moderna e participativa e criou o Sistema de Gerenciamento de Recursos Hídricos, dando execução ao disposto no artigo 21, inciso XIX da Constituição Federal (BRASIL, 1988). Segundo BORSOI e TORRES (2010), esta lei incorpora princípios, normas e padrões de gestão de água já aceitos e praticados em muitos países e, por isso, representa um novo marco institucional no país.

Esta lei, também conhecida como Lei das Águas, fixa no artigo $1^{\circ}$ os fundamentos para a Política Nacional de Recursos Hídricos (BRASIL, 1997), conforme segue:

"I - a água é um bem de domínio público;

II - a água é um recurso natural limitado, dotado de valor econômico;

III - em situações de escassez, o uso prioritário dos recursos hídricos é o consumo humano e a dessedentação de animais;

IV - a gestão dos recursos hídricos deve sempre proporcionar o uso múltiplo das águas; 
V - a bacia hidrográfica é a unidade territorial para a implementação da Política Nacional de Recursos Hídricos e atuação do Sistema Nacional de Gerenciamento de Recursos Hídricos;

VI - a gestão dos recursos hídricos deve ser descentralizada e contar com a participação do Poder Público, dos usuários e das comunidades".

Com a adoção do princípio do uso múltiplo das águas, foi minimizado o comando do setor elétrico sobre as questões relativas à gestão das águas (BORSOI e TORRES, 2010) e, com a maior importância dada à participação pública, em especial dos usuários e da sociedade civil, buscou-se dar maior legitimidade à decisão e aumentar a garantia de implantação das decisões tomadas (PORTO e PORTO, 2008).

É importante observar que a bacia hidrográfica, em muitos casos, apresenta limites diferentes da divisão administrativa, isto é, da divisão dos estados e municípios. PORTO e PORTO (2008) consideram que "não há um recorte geográfico que seja ideal para todos os agentes que participam do processo" e que o recorte por bacia hidrográfica é vantajoso na medida em que "guarda relação física direta com a água, que é o bem objeto desta gestão" (p. 58). Dessa forma, a gestão por bacias "pode proporcionar uma efetiva integração das políticas públicas e ações regionais, o que por si só é bastante positivo" (MMA, 2009a, p. 13).

Em seu $2^{\circ}$ artigo, são apresentados os objetivos da Política (BRASIL, 1997), enumerados a seguir:

"I - assegurar à atual e às futuras gerações a necessária disponibilidade de água, em padrões de qualidade adequados aos respectivos usos;

II - a utilização racional e integrada dos recursos hídricos, incluindo o transporte aquaviário, com vistas ao desenvolvimento sustentável;

III - a prevenção e a defesa contra eventos hidrológicos críticos de origem natural ou decorrentes do uso inadequado dos recursos naturais". 
As diretrizes gerais de ação estabelecidas pelo artigo 3ำ da Lei ํำ 9433/97 para a gestão de recursos hídricos (BRASIL, 1997) são:

"I - a gestão sistemática dos recursos hídricos, sem dissociação dos aspectos de quantidade e de qualidade;

II - a adequação dos recursos hídricos às diversidades físicas, bióticas, demográficas, econômicas, sociais e culturais das diversas regiões do País;

III - a integração da gestão de recursos hídricos com a gestão ambiental;

IV - a articulação do planejamento de recursos hídricos com o dos setores usuários e com os planejamentos regional, estadual e nacional;

V - a articulação da gestão de recursos hídricos com a gestão do uso do solo;

VI - a integração da gestão das bacias hidrográficas com a dos sistemas estuarinos e zonas costeiras".

Para possibilitar a implementação da Política Nacional de Recursos Hídricos, foram instituídos instrumentos de gestão através do artigo 5ํㅜㅇ como segue (BRASIL, 1997):

"I - os Planos de Recursos Hídricos;

II - o enquadramento dos corpos d'água em classes, segundo os usos preponderantes da água;

III - a outorga de direito de uso dos recursos hídricos;

IV - a cobrança pelo uso dos recursos hídricos;

V - a compensação a Municípios;

VI - o Sistema de Informações sobre Recursos Hídricos".

Planos de Recursos Hídricos são planos diretores que, na forma do artigo 6ํ da Lei das Águas, "visam a fundamentar e orientar a implementação da Política Nacional de Recursos Hídricos e o gerenciamento dos recursos hídricos“ (BRASIL, 1997). São "planos de longo prazo” (BRASIL, 1997, art. $7^{\circ}$ ) e devem ser "elaborados por bacia hidrográfica, por Estado e para 0 
País" (BRASIL, 1997, art. 8º). É através do Plano de Recursos Hídricos por bacia hidrográfica que se define como conservar, recuperar e utilizar os recursos hídricos daquela bacia, enquanto que o Plano Nacional de Recursos Hídricos apresenta as estratégias para cuidar das águas do país, orientando políticas públicas que tenham interação com a gestão de recursos hídricos (MMA, 2009a).

O enquadramento dos corpos d'água em classes segundo os usos preponderantes deve obedecer às normas da legislação ambiental e deve estar em conformidade com os Planos de Recursos Hídricos da bacia, Estadual e Nacional (SMA, 2004). Tem como objetivos "assegurar às águas qualidade compatível com os usos mais exigentes a que forem destinadas e diminuir os custos de combate à poluição das águas, mediante ações preventivas permanentes" (MMA, 2009a, p. 32).

A outorga de direito de uso dos recursos hídricos é o instrumento pelo qual o Poder Público autoriza o usuário a utilizar as águas de seu domínio, quer seja para derivação ou captação, extração de aquíferos subterrâneos, lançamento de efluentes ou aproveitamento para geração de energia. $O$ artigo 11 da Lei no 9433/97 aponta como objetivos deste instrumento "assegurar o controle quantitativo e qualitativo dos usos da água e o efetivo exercício dos direitos de acesso à água" (MMA, 2009a, p. 32).

Considerada como um dos instrumentos fundamentais para a implantação da Política Nacional de Recursos Hídricos, a cobrança pelo uso dos recursos hídricos foi instituída com o objetivo de reconhecer a água como bem econômico, dar ao usuário uma indicação de seu real valor, incentivar o uso racional da água e obter recursos financeiros para financiar programas e intervenções contemplados nos planos de recursos hídricos (SMA, 2004; ANA, 2009). A lei prevê, em seu artigo 22, que os valores arrecadados com a cobrança sejam aplicados prioritariamente na bacia 
hidrográfica em que forem gerados e que esses recursos sejam utilizados para financiar estudos, programas e obras incluídos nos planos de recursos hídricos, como também para cobrir as despesas de implantação e custeio administrativo dos órgãos e das entidades que integram o Sistema Nacional de Gerenciamento de Recursos Hídricos (PEREIRA, 2008). Tal instrumento, que representa também um estímulo à não-poluição, deve ser aplicado a todos os usuários submetidos à exigência da outorga (PEREIRA, 2003).

O projeto de lei previa, em seu artigo 24, a compensação financeira ou de outro tipo a municípios com áreas inundadas por reservatórios ou sujeitas a restrições de uso do solo referentes à proteção de recursos hídricos. Como "o mecanismo compensatório proposto não encontra apoio no texto da Carta Magna", este artigo foi vetado (SMA, 2004, p. 84).

O artigo 25 define o Sistema de Informações sobre Recursos Hídricos como "um sistema de coleta, tratamento, armazenamento e recuperação de informações sobre recursos hídricos e fatores intervenientes em sua gestão" (BRASIL, 1997). Os dados gerados pelos órgãos integrantes do Sistema Nacional de Gerenciamento de Recursos Hídricos serão incorporados ao Sistema de Informações, a obtenção e a produção de dados e informações deverão ser descentralizadas e a sociedade deverá ter acesso garantido a eles.

GRANZIERA (2001) classifica tais instrumentos da Política em dois grupos. No $1^{\circ}$ grupo, relativo ao planejamento, estão os planos de bacia hidrográfica, o enquadramento dos corpos d'água em classes e o sistema de informações sobre recursos hídricos. Tais instrumentos têm a função de organizar e definir a utilização da água, solucionando ou minimizando os efeitos dos conflitos de interesse. No $2^{\circ}$ grupo, voltado ao controle administrativo do uso, estão a outorga de direito de uso e, de forma 
indireta, a cobrança pelo uso dos recursos hídricos. A autora não classifica o $5^{\circ}$ instrumento da Lei - a compensação a municípios, devido ao veto do artigo 24, referente a ele, porém algumas leis estaduais apresentam mecanismos similares a este instrumento. PORTO e PORTO (2008) argumentam que, apesar de ter seu artigo vetado, o mecanismo de compensação a municípios não foi eliminado como instrumento de gestão, é essencial por fazer a ligação entre a gestão dos recursos hídricos e a gestão territorial, e classificam esse instrumento e a cobrança pelo uso da água, em instrumentos de incentivo econômico à gestão adequada dos recursos hídricos.

SOUZA (2000) afirma que a outorga e a cobrança sobre os usos da água "não são formas de arrecadação nem formas de favorecimento de grupos sociais", mas sim um "modo de implementar desenvolvimento observando as peculiaridades espaciais e considerando um horizonte temporal mais amplo, atendendo aos pressupostos do desenvolvimento sustentável" ( $p$. 95).

Segundo PEREIRA (2003):

"A implementação desses instrumentos de gestão - fortemente interdependentes e complementares do ponto de vista conceitual demanda não somente capacidades técnicas, políticas e institucionais, mas também tempo para sua definição e operacionalização. Afinal, a implantação da gestão e de seus instrumentos é, antes de tudo, um processo organizativo-social, o qual demanda participação e aceitação por parte dos atores envolvidos, dentro da compreensão de que haverá um benefício coletivo global" (p. 11).

Para colocar em prática essa política, a Lei o 9433/97 cria o Sistema Nacional de Gerenciamento de Recursos Hídricos (SINGREH), cuja composição, apresentada na figura 1, está determinada através do artigo 33 (BRASIL, 1997), como segue:

"Art. 33 Integram o Sistema Nacional de Gerenciamento de Recursos Hídricos: 
I - o Conselho Nacional de Recursos Hídricos;

IA - a Agência Nacional de Águas; (Acrescentado)

II - os Conselhos de Recursos Hídricos dos Estados e do Distrito Federal;

III - os Comitês de Bacia Hidrográfica;

IV - os órgãos dos poderes públicos federal, estaduais, do Distrito Federal e municípios cujas competências se relacionem com a gestão de recursos hídricos; (Nova Redação)

V - as Agências de Água".

Figura 1: Sistema Nacional de Gerenciamento de Recursos Hídricos

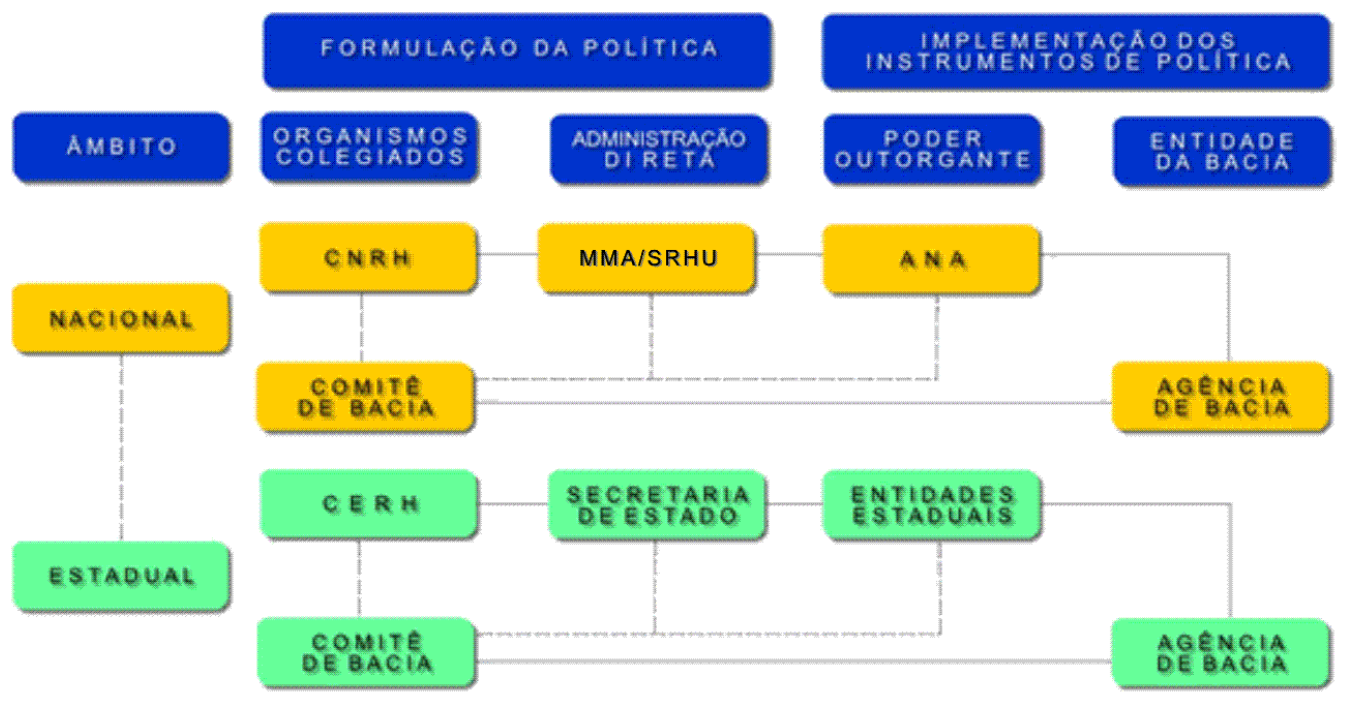

Fonte: MMA, 2009b

O Conselho Nacional de Recursos Hídricos (CNRH) é o órgão mais expressivo da hierarquia do SINGREH e possui caráter normativo e deliberativo. Tem como atribuições principais subsidiar a formulação da Política de Recursos Hídricos e dirimir conflitos relativos aos usos da água. A Secretaria Executiva do $\mathrm{CNRH}$ é exercida pela Secretaria de Recursos Hídricos e Ambiente Urbano do Ministério do Meio Ambiente (SRHU/MMA), cujas atribuições são formular a Política Nacional de 
Recursos Hídricos e subsidiar a formulação do Orçamento da União. À Agência Nacional de Águas (ANA), autarquia especial vinculada ao Ministério do Meio Ambiente (MMA), cabe implementar o Sistema Nacional de Recursos Hídricos, outorgar e fiscalizar o uso de recursos hídricos de domínio da União (MMA, 2009b).

A estrutura é similar no âmbito dos Estados, com os Conselhos Estaduais de Recursos Hídricos, os órgãos executivos estaduais e as agências de bacias.

Dentre estes organismos, convém destacar a instância de decisão local em cada bacia hidrográfica, que são os Comitês de Bacia Hidrográfica (CBHs). São colegiados consultivos e deliberativos, também conhecidos como Parlamentos das Águas. Dentre suas obrigações destacam-se a promoção de debate sobre questões relacionadas aos recursos hídricos, "a articulação entre os diversos agentes, a atuação em primeira instância em caso de conflito, a aprovação do plano de recursos hídricos e a aprovação da implantação da cobrança e da proposta de preço" (PORTO e PORTO, 2008, p. 49).

Os Comitês de Bacia Hidrográfica, conforme definido no Artigo 39 da Lei no 9433/97, são compostos por representantes da União; dos Estados e do Distrito Federal cujos territórios se situem, ainda que parcialmente, em suas respectivas áreas de atuação; dos Municípios situados, no todo ou em parte, em sua área de atuação; dos usuários das águas de sua área de atuação; e das entidades civis de recursos hídricos com atuação comprovada na bacia (BRASIL, 1997). O inciso 1ำ deste artigo define que "a representação dos poderes executivos da União, Estados, Distrito Federal e Municípios" está limitada "à metade do total de membros" dos comitês (BRASIL, 1997). 
GRANZIERA (2001) ressalta que "não foi prevista a participação de cidadãos no Sistema de Gerenciamento de Recursos Hídricos, mas apenas de organizações civis" (p. 155-156). Conforme artigo 47 desta lei, são consideradas organizações civis de recursos hídricos:

"I - consórcios e associações intermunicipais de bacias hidrográficas;

II - associações regionais, locais ou setoriais de usuários de recursos hídricos;

III - associações técnicas e de ensino e pesquisa com interesse na área de recursos hídricos;

IV - organizações não-governamentais com objetivos de defesa de interesses difusos e coletivos da sociedade;

V - outras organizações reconhecidas pelo Conselho Nacional ou pelos Conselhos Estaduais de Recursos Hídricos" (BRASIL, 1997).

Cabe a cada comitê definir em seu regimento interno os critérios para eleição ou indicação de seus membros, bem como o detalhamento da composição desta representação, isto é, o número de vagas destinadas a cada setor (CARDOSO, 2003). O Conselho Nacional de Recursos Hídricos (CNRH), porém, através do Artigo $8^{\circ}$ da Resolução $n^{\circ}$ 5, de 10 de abril de 2000, limita a representação dos poderes executivos federal, estadual e municipal a $40 \%$ dos votos, o número de representantes dos usuários também a $40 \%$ dos votos, e fixa o mínimo de $20 \%$ dos votos para a representação de entidades civis, desde que garantida a participação de pelo menos um representante de cada Estado e do Distrito Federal (MMA, 2008a).

Para BORSOI e TORRES (2010), "as condições básicas para entrar em nova fase de gerenciamento de seus recursos hídricos, na qual todos os usuários, as comunidades envolvidas e os governos regionais e locais decidem pelo melhor uso da água e pelos investimentos necessários, organizados em torno de suas bacias" (p. 14), foram criadas a partir da promulgação da Lei Federal no 9433/97. E assim, "o que se espera com o 
modelo sistêmico de integração participativa é a criação de uma vontade política regional que, além de arrecadar recursos, tenha sucesso na administração pública, promovendo o uso e a proteção das águas" (p. 11).

\subsection{POLÍTICAS ESTADUAIS DE RECURSOS HÍDRICOS}

A partir da Constituição de 1988, vários estados brasileiros aprovaram leis que reorganizaram o sistema de gestão dos recursos hídricos antes mesmo da promulgação da lei federal, cuja tramitação no Congresso Nacional se estendeu de 1991 a 1997. São Paulo foi o primeiro a regulamentar sua política estadual, em 1991, que será abordada com mais detalhes no item 5.4. Além de São Paulo, também promulgaram leis de recursos hídricos definindo suas políticas antes da aprovação da Lei Federal no 9433/97, o Estado do Ceará em 1992, o Distrito Federal em 1993, os Estados de Minas Gerais, Santa Catarina e Rio Grande do Sul em 1994, Bahia em 1995 e Rio Grande do Norte e Paraíba em 1996 (BARTH, 1999). No próprio ano de 1997, mais 5 estados - Maranhão, Pernambuco, Alagoas, Mato Grosso e Sergipe - promulgaram suas leis (NORONHA, 2006). Segundo CARDOSO (2003), o respaldo dado pela Política Nacional foi significativo no processo nos estados, fazendo com que apenas um ano depois de sua promulgação, 14 estados já dispunham de suas leis de recursos hídricos.

A política adotada no Estado do Ceará, aprovada em 24 de julho de 1992, tem grande semelhança com a paulista: a bacia hidrográfica é a unidade de gestão, o planejamento territorial é integrado e há um fundo estadual de recursos hídricos. Sua gestão está sob a responsabilidade da Companhia de Gestão de Recursos Hídricos do Estado de Ceará (COGERH) e é feita através dos instrumentos: outorga de direito de uso, enquadramento dos corpos d'água e cobrança pelo uso da água. O Estado do Ceará foi o pioneiro na implantação da cobrança pelo uso da água de domínio 
estadual. Este instrumento, aplicado de uma maneira extremamente simples com base apenas nos aspectos quantitativos, sem o uso de coeficientes ponderadores, vem sendo efetivado desde dezembro de 1996 (BORGES, 2008).

A lei cearense não trata detalhadamente da composição dos colegiados, citando somente a participação de secretarias de estado e de instituições federais envolvidas com recursos hídricos; dos municípios, de usuários das águas públicos ou privados, de universidades e instituições de pesquisa e da sociedade civil.

A Política de Recursos Hídricos instituída no Distrito Federal em 1993 adota os mesmos princípios, diretrizes e instrumentos da lei paulista, porém difere quanto aos colegiados que compõem o sistema. A lei brasiliense instituiu três colegiados, a saber:

- "Órgão gestor distrital, de natureza deliberativa e executiva;

- Colegiado Distrital, com atribuições consultivas, deliberativas e normativas; e

- Comitês de Bacias Hidrográficas, com funções consultivas" (BARTH, 1999, p. 578).

O Colegiado Distrital é integrado por órgãos e entidades distritais e por instituições de ensino superior e pesquisa apenas, sem a participação de usuários ou entidades de classe. Os Comitês de Bacias do Distrito Federal são integrados por:

- "Representantes de Secretarias de Estado ou de órgãos e entidades da administração indireta;

- Representantes das regiões administrativas contidas na bacia hidrográfica; e

- Representantes da sociedade civil, com no máximo $1 / 3$ dos votos, representada por usuários das águas e associações especializadas em 
recursos hídricos, entidades de classe e associações comunitárias" (BARTH, 1999, p. 578).

O Estado de Minas Gerais, cuja lei foi promulgada em 1994, seguiu os mesmos princípios, diretrizes e instrumentos adotados pelos demais estados, porém não previu um fundo estadual de recursos hídricos. Quanto aos colegiados que integram o sistema mineiro, cabe ressaltar a composição dos comitês de bacia, onde metade dos membros é formada por representantes do poder público estadual e municipal, de forma paritária, e a outra parte é formada por usuários e entidades da sociedade civil (BARTH, 1999).

Nos Estados de Santa Catarina e do Rio Grande do Sul, cujas leis foram instituídas em 1994 e adotaram os mesmos princípios, diretrizes e instrumentos das demais, a composição dos Comitês de Gerenciamento de Bacias Hidrográficas privilegia os usuários e representantes locais, ao adotar a seguinte composição:

- Usuários da água - $40 \%$ dos votos;

- Representantes da população da bacia, através dos executivos e legislativos municipais $-40 \%$ dos votos; e

- Representantes de órgãos federais e estaduais atuantes na bacia $20 \%$ dos votos (BARTH, 1999).

Dentre as demais leis estaduais promulgadas, cabe salientar a do Estado de Pernambuco, aprovada em 17/01/97, logo após a Política Nacional de Recursos Hídricos. O Sistema de Gerenciamento pernambucano é formado por três colegiados:

- Conselho Estadual de Recursos Hídricos, com composição tripartite, sendo 9 representantes do estado, 7 representantes das prefeituras e 2 de entidades não-governamentais (indústrias e entidades de estudo e pesquisa em recursos hídricos e meio ambiente); 
- Comitê Estadual de Recursos Hídricos, com representantes do estado, dos comitês de bacias, de entidades federais, de entidades técnico-profissionais e das universidades e centros de pesquisa; e

- Comitês de Bacias Hidrográficas, também tripartites - as entidades federais atuantes nas bacias podem participar, porém apenas com direito a voz (BARTH, 1999).

A partir da promulgação das Políticas Nacional e Estaduais de Recursos Hídricos, "o país mudou de uma gestão institucionalmente fragmentada, para uma legislação integrada e descentralizada" (JACOBI et al., 2009, p. 74).

\subsection{POLÍTICA DE RECURSOS HÍDRICOS DO ESTADO DE SÃO PAULO}

No final da década de 1980, o Estado de São Paulo já apresentava problemas devido à escassez de água em algumas regiões, em especial nas bacias congestionadas como do Alto Tietê, Baixada Santista, Piracicaba, Paraíba do Sul, Jundiaí e Capivari. CESAR NETO (1988) escreveu que "nessas bacias, esse importante recurso natural já deixou de ser um vetor, tornando-se um fator de restrição ao processo de desenvolvimento" (p. XV).

Tornou-se então urgente a necessidade de planejar e controlar o uso da água para possibilitar o desenvolvimento econômico no Estado com "o máximo de benefícios e o mínimo de custos para a população como um todo" (CESAR NETO, 1988, p. 15).

A partir do início da redemocratização do país, várias inovações na gestão de recursos hídricos foram introduzidas. A Constituição de 1988 abriu as portas para a descentralização, reforçada pela Constituição Paulista, promulgada em 5 de outubro de 1989 (CBH PCJ, 1998). Porém, antes mesmo da própria constituição, o Estado de São Paulo criou "o Conselho 
Estadual de Recursos Hídricos (CRH) em 1987, com a tarefa de propor a política e elaborar o Plano Estadual de Recursos Hídricos, e a estruturação do Sistema Estadual de Gestão dos Recursos Hídricos" (SMA, 2004, p. 85).

Algumas iniciativas voltadas para a defesa das águas da região dos rios Piracicaba, Capivari e Jundiaí encontravam-se em andamento quando, por iniciativa dos prefeitos de Piracicaba e de Bragança Paulista, foi criado o Consórcio Intermunicipal das Bacias dos Rios Piracicaba e Capivari, com a adesão de 12 municípios, em 1989 (CBH PCJ, 1998; ANA, 2009). Para os autores PORTO e PORTO (2008), foi "uma atitude inovadora por ter nascido na administração local e por prever um plenário de entidades, em que a sociedade civil é convidada a participar no processo de tomada de decisão" (p. 44).

A abertura para a participação na gestão das águas, não só de representantes da sociedade civil organizada, como também de membros dos órgãos da administração municipal, surgiu com a Constituição paulista, pois, até sua promulgação, "as linhas gerais que regeram o uso dos recursos hídricos mostram que a Sociedade Civil e os Municípios foram alijados do processo decisório" (SMA, 1995, p. 15). A importância desta participação é mostrada por Dowbor, como traz MARIANO (1996), ao afirmar que "não existe modelo matemático de avaliação de projeto, nem mesmo computador capaz de substituir o conhecimento da realidade existente na população local, que assegure as realizações correspondentes aos anseios dos interesses comuns à sociedade" (p. 68).

Em 1990, foi elaborado o Plano Estadual de Recursos Hídricos - um amplo diagnóstico da situação dos recursos hídricos por bacias hidrográficas (ROCHA, 1998). Segundo ALVIM (2003), o Plano de 1990, apesar de seu caráter preliminar, foi significativo no desencadeamento da 
nova política de recursos hídricos. Neste plano foi apresentada a primeira divisão hidrográfica para o Estado para fins de gestão dos recursos hídricos - as 22 Unidades de Gerenciamento de Recursos Hídricos, as UGRHIs.

No dia 30 de dezembro de 1991, o Estado de São Paulo regulamentou, através da Lei № 7663, a instituição da Política Estadual de Recursos Hídricos e a organização e a implementação do Sistema Integrado de Gerenciamento dos Recursos Hídricos (SIGRH), conforme os princípios da Constituição Paulista de 1989. A importância desta lei no cenário de recursos hídricos é apontada pela Secretaria do Meio Ambiente do Estado de São Paulo (SMA), pois, além de ter "servido de inspiração não só para a Política Nacional de Recursos Hídricos, mas também para muitos Estados da Federação, a Lei 7663 (...) significou uma mudança de paradigma na gestão nacional dos recursos hídricos" (SMA, 2004, p. 87).

O objetivo da Política Estadual de Recursos Hídricos, disposto no artigo $2^{\circ}$ da Lei, é "assegurar que a água, recurso natural essencial à vida, ao desenvolvimento econômico e ao bem-estar social, possa ser controlada e utilizada, em padrões de qualidade satisfatórios, por seus usuários atuais e pelas gerações futuras, em todo território do Estado de São Paulo" (DAEE, 2006, p. 5).

Os princípios a serem atendidos pela Política paulista encontram-se listados no artigo $3^{\circ}$, conforme segue:

"I - gerenciamento descentralizado, participativo e integrado, sem dissociação dos aspectos quantitativos e qualitativos e das fases meteórica, superficial e subterrânea do ciclo hidrológico;

II - a adoção da bacia hidrográfica como unidade físico-territorial de planejamento e gerenciamento;

III - reconhecimento do recurso hídrico como um bem público, de valor econômico, cuja utilização deve ser cobrada, observados os aspectos de quantidade, qualidade e as peculiaridades das bacias hidrográficas; 
IV - rateio de custo das obras de aproveitamento múltiplo de interesse comum ou coletivo, entre os beneficiados;

V - combate e prevenção das causas e dos efeitos adversos da poluição, das inundações, das estiagens, da erosão do solo e do assoreamento dos corpos d'água;

VI - compensação aos municípios afetados por áreas inundadas resultantes da implantação de reservatórios e por restrições impostas pelas leis de proteção de recursos hídricos;

VII - compatibilização do gerenciamento dos recursos hídricos com o desenvolvimento regional e com a proteção do meio ambiente" (DAEE, 2006, p. 5-6).

Em seus artigos $5^{\circ}$ e 31 , foi previsto o incentivo pelo Estado à formação de consórcios entre os municípios em bacias hidrográficas críticas para a realização de programas regionais de desenvolvimento e de proteção ambiental. $\mathrm{O}$ artigo 6ำ prevê a promoção de ações integradas nas bacias hidrográficas para tratamento de efluentes urbanos e industriais com os meios financeiros e institucionais previstos nesta lei (DAEE, 2006).

A Política Estadual de Recursos Hídricos estabelece, em seus Capítulos II e III (DAEE, 2006), os seguintes instrumentos de gestão:

- Outorga de Direitos de Uso dos Recursos Hídricos;

- Infrações e Penalidades;

- Cobrança pelo Uso dos Recursos Hídricos;

- Rateio de Custos das Obras;

- Plano Estadual de Recursos Hídricos; e

- Planos de Bacias Hidrográficas.

Alguns desses instrumentos também estão presentes na Política Nacional e encontram-se descritos no item 5.2. Há diferenciação quanto a Infrações e Penalidades, previstas na legislação paulista como instrumento de gestão. GRISOTTO (2003), porém, considera que "esse mecanismo está relacionado aos demais instrumentos, por exemplo, à outorga e à 
cobrança pelo direito de uso das águas, regulando o seu exercício" (p. 48). Outra diferença entre as legislações federal e paulista é o estabelecimento de Rateio de Custos das Obras, previsto para obras de recursos hídricos de uso múltiplo ou de interesse comum ou coletivo, cujos procedimentos estão relatados no artigo 15 da Lei Estadual oㅜ 7663/91.

Apesar de não ser considerado na legislação como instrumento de gestão, o Fundo Estadual de Recursos Hídricos (FEHIDRO), tratado nos artigos 35 a 37 desta lei como um órgão de apoio ao processo de gestão de bacias, tem sido considerado em muitos casos como um instrumento econômico, segundo GRISOTTO (2003). Trata-se de um fundo financeiro, "com recursos financeiros do tesouro do Estado, dos royalties do setor elétrico e da cobrança pelo uso da água, administrados de forma descentralizada por meio de sub-contas nas bacias" (ROCHA, 1998, p. 4).

Visando a avaliação da eficácia do Plano Estadual de Recursos Hídricos e dos Planos de Bacias Hidrográficas, como também para dar transparência à administração pública, esta lei determina, em seu artigo 19, que deverão ser publicados relatórios anuais sobre a Situação dos Recursos Hídricos no Estado de São Paulo e sobre a Situação dos Recursos Hídricos das Bacias Hidrográficas (DAEE, 2006).

O artigo 20 da Lei 7663/91 dispõe que: "Constará do Plano Estadual de Recursos Hídricos a Divisão Hidrográfica do Estado que definirá unidades hidrográficas, com dimensões e características que permitam e justifiquem o gerenciamento descentralizado dos recursos hídricos" (DAEE, 2006, p. 12).

O território do Estado de São Paulo foi dividido em 22 Unidades de Gerenciamento de Recursos Hídricos (UGRHIs). A divisão destas regiões teve como base o divisor de águas das respectivas bacias hidrográficas 
(ALVIM e RONCA, 2007) e apresentam diferenças quanto ao tamanho (número de municípios, área e população), como também quanto à disponibilidade hídrica e à complexidade de gestão. Para definição dessa divisão, apresentada no Plano Estadual de Recursos Hídricos de 1990, foi feita agregação de sub-bacias com características similares e forte interdependência. Foram consideradas características físicas, tais como clima da área, perfil hidrológico e aquífero; características sócioeconômicas, como uso do solo; e características políticas, em especial os limites administrativos municipais (CESAR NETO, 1988; MARIANO, 1996).

Para a execução da Política Estadual de Recursos Hídricos e a formulação e aplicação do Plano Estadual de Recursos Hídricos, foram estabelecidas as normas para o Sistema Integrado de Gerenciamento de Recursos Hídricos (SIGRH), composto por órgãos colegiados, consultivos e deliberativos, de nível estratégico: o Conselho Estadual de Recursos Hídricos $(\mathrm{CRH})$, de nível central, e os Comitês de Bacias Hidrográficas (CBHs), com atuação em cada unidade hidrográfica (DAEE, 2006).

Conforme artigo 23 (DAEE, 2006), o CRH deve ser formado de forma paritária por:

- Representantes dos Secretários de Estado, cujas atividades se relacionem com o gerenciamento ou uso dos recursos hídricos, a proteção do meio ambiente, o planejamento estratégico e a gestão financeira do Estado;

- Representantes dos municípios contidos nas bacias hidrográficas, eleitos entre seus pares; $\mathrm{e}$

- Representantes de universidades, institutos de ensino superior e de pesquisa, do Ministério Público e da sociedade civil organizada.

Apesar de não terem direito a voto, também participam do $\mathrm{CRH}$ os presidentes dos comitês de bacias. As decisões deste colegiado são tomadas por maioria simples de votos (OLIVI, 2004). 
O artigo 24 da Lei Estadual ํo 7663/91 dispõe que:

"Artigo 24 - Os Comitês de Bacias Hidrográficas, assegurada a participação paritária dos Municípios em relação ao Estado serão compostos por:

I - representantes da Secretaria de Estado ou de órgãos e entidade da administração direta e indireta, cujas atividades se relacionem com o gerenciamento ou uso de recursos hídricos, proteção ao meio ambiente, planejamento estratégico e gestão financeira do Estado, com atuação na bacia hidrográfica correspondente;

II - representantes dos municípios contidos na bacia hidrográfica correspondente;

III - representantes de entidades da sociedade civil, sediadas na bacia hidrográfica, respeitado o limite máximo de um terço do número total de votos, por:

a) universidades, institutos de ensino superior e entidades de pesquisa e desenvolvimento tecnológico;

b) usuários das águas, representados por entidades associativas;

c) associações especializadas em recursos hídricos, entidades de classe e associações comunitárias, e outras associações não governamentais" (DAEE, 2006, p. 13).

É importante ressaltar que "à Sociedade Civil caberia a contraposição às posições do poder público, afirmando a posição da comunidade, trazendo para o plenário a vivência cotidiana da questão da água, seja por parte de empresários, ambientalistas ou sindicalistas" (SMA, 1995, p. 29).

Cada comitê deve possuir composição e regras de funcionamento próprias, regidas por seu estatuto e atreladas à lei estadual que, conforme descrito acima, assegura uma composição tripartite e paritária, isto é, os comitês são compostos por igual número de representantes dos órgãos do Estado, da Sociedade Civil e dos Governos Municipais (ALVIM e RONCA, 2007).

Conforme relatado nos itens 5.2 e 5.3, nos comitês federais e nos comitês de outros estados, a representação está estabelecida de forma diferente, 
tendo uma representação dos usuários, sejam eles da iniciativa privada ou pública, uma representação da sociedade civil diferente da que ocorre nos comitês paulistas, além dos representantes dos diversos níveis de governo.

A Lei Estadual oㅜ 7663/91 dispõe também que (DAEE, 2006):

- A duração dos mandatos dos integrantes dos comitês de bacias será de 2 anos;

- O comitê de bacia deverá se reunir ordinariamente no mínimo duas vezes ao ano;

- Há três cargos eletivos no comitê: Presidente, Vice-Presidente e Secretário Executivo;

- Cada segmento indicará seu representante dentre os membros do comitê para o cargo definido pela plenária para aquele segmento; e

- Os comitês poderão criar câmaras técnicas de caráter consultivo, para o tratamento de questões específicas de interesse para o gerenciamento dos recursos hídricos.

Segundo NEDER (2000), tais câmaras técnicas "correspondem a um espaço de produção de consenso" (p. 37), pois são responsáveis pelas discussões e construção de acordos necessários para atender aos diferentes interesses setoriais, antes do encaminhamento dos assuntos para as reuniões plenárias dos respectivos comitês de bacia ou conselhos de recursos hídricos. Como espaço de assessoramento técnico, "quanto mais especializadas, mais adequados serão os estudos técnicos das CTs" (MMA, 2008b, p. 34).

As normas gerais para composição, organização, competência e funcionamento dos comitês de bacias hidrográficas foram definidas através da Deliberação $\mathrm{CRH}$ no $02 / 93$. Dentre as competências definidas nos artigos 10, 11 e 12 desta Deliberação (DAEE, 2006), destacam-se: 
- Deliberar sobre a proposta da bacia hidrográfica para integrar o Plano Estadual de Recursos Hídricos e suas atualizações;

- Propor programas anuais e plurianuais de aplicação de recursos financeiros em serviços e obras de interesse para o gerenciamento dos recursos hídricos;

- Propor valores a serem cobrados pela utilização dos recursos hídricos da bacia hidrográfica;

- Deliberar sobre planos e programas a serem executados com recursos obtidos da cobrança;

- Propor plano de utilização, conservação, proteção e recuperação dos recursos hídricos da bacia;

- Deliberar sobre proposta para o enquadramento dos corpos d'água em classes de uso preponderantes;

- Promover entendimentos, cooperação e eventual conciliação entre os usuários dos recursos hídricos;

- Acompanhar a execução da Política Estadual de Recursos Hídricos na área de atuação do comitê;

- Apreciar o relatório sobre A Situação dos Recursos Hídricos da Bacia Hidrográfica até 31 de março de cada ano; e

- Acompanhar a aplicação de recursos financeiros.

Segundo ROCHA (1998), o sistema de gestão está ancorado em três instâncias interdependentes de cuja articulação depende o sucesso dos programas e ações nas áreas de recursos hídricos, saneamento e meio ambiente. São elas: os colegiados, sendo um central - o Conselho Estadual de Recursos Hídricos, e os outros regionais - os Comitês de Bacia Hidrográfica; o Plano Estadual de Recursos Hídricos, elaborado a partir dos planos de bacias e atualizado a cada quatro anos; e um fundo financeiro - o Fundo Estadual de Recursos Hídricos (FEHIDRO). 


\subsection{SITUAÇÃO ATUAL DO SISTEMA DE GESTÃO DE RECURSOS HÍDRICOS NO BRASIL}

Com a promulgação das novas leis das águas, federal e estaduais, surge a figura do comitê de bacia como um "órgão público de Estado constituído por todos os envolvidos e interessados pela água" (PEREIRA, 2003, p. 13), com atribuições e responsabilidades próprias, que não devem ser confundidas com as atribuições e as responsabilidades dos órgãos gestores públicos. PEREIRA (2003) constata que "a inovação institucional ocorreu principalmente nos espaços vazios ante a criação de organismos de tomada de decisão em nível nacional, estadual e de bacia (conselhos e comitês), que passaram a incorporar novos atores (municípios, usuários e organizações civis) ao processo de gestão" (p. 13). A autora finaliza afirmando que tais legislações "propõem transformações profundas nas práticas de gestão das águas e suscitam importantes desafios para sua implementação" (p. 13).

Passados 14 anos da promulgação da Lei Federal no 9433/97, MACHADO (2010) lista vários feitos que podem ser contabilizados ao se analisar o Sistema Nacional de Gerenciamento de Recursos Hídricos (SINGREH) já instituído. Dentre eles, destacam-se: "o estabelecimento do marco legal de recursos hídricos em todos os estados da federação; o funcionamento regular do Conselho Nacional de Recursos Hídricos; a criação e funcionamento robusto da Agência Nacional de Águas; a estruturação dos órgãos gestores de recursos hídricos e dos conselhos estaduais na maioria dos estados; e a criação e o funcionamento de cerca de 150 comitês de bacia" (p. 6). Relata também a elaboração e a implementação do Plano Nacional de Recursos Hídricos, de alguns planos estaduais e de bacias; o "desenvolvimento de um Sistema Nacional de Informações sobre Recursos Hídricos em colaboração crescente com vários sistemas estaduais" (p. 6); além da "capacitação técnica crescente e incorporação crescente de novos profissionais na área de recursos hídricos" (p. 6). 
Em alguns estados da federação, muitos progressos foram alcançados no gerenciamento de recursos hídricos, que serão abordados nos itens a seguir. Porém, em algumas regiões do país, em especial, alguns estados das Regiões Hidrográficas Amazônica, do Tocantins-Araguaia e do Paraguai, pouco se fez até o momento.

Segundo GRANZIERA (2001):

"O Sistema de Gerenciamento de Recursos Hídricos encontra-se em fase de implantação. Alguns Estados, cujas leis foram editadas há mais tempo, já possuem um quadro mais definitivo. De qualquer forma, quando se fala em um Sistema administrativo, com a função primordial de fazer girar a roda de determinada política, a montagem e funcionamento desse sistema é basicamente um processo, entendido como o encadeamento de fatos e atos que se desenvolvem ao longo do tempo.

É um processo em que não há um ato final, ou uma decisão, mas apenas um momento em que todas as engrenagens, já testadas, encontram-se em funcionamento e podem, sempre, ser aperfeiçoadas, à medida que as metas iniciais se realizam, e outras, novas, talvez mais ousadas ou sofisticadas, tomam seu lugar" (p. 167-168).

\subsubsection{Implantação dos Comitês de Bacias Hidrográficas Federais}

PEREIRA (2003) afirma que: "Em termos técnicos, políticos e institucionais, os pontos sensíveis no exercício de práticas de gestão integrada dos recursos hídricos concentram-se nas interfaces entre setores usuários e gestores e na compatibilização e harmonização da gestão entre gestores estaduais e federais e entre comitês de uma mesma bacia hidrográfica" (p. 14). Nos casos de bacias nacionais, tais interfaces acontecem por envolverem a União e dois ou mais estados, com políticas estaduais distintas. A implantação de comitês em bacias de rios de dominialidade federal exige, portanto, o enfrentamento e a superação dessas diferenças. 
Em 1996, durante a discussão do projeto da lei o 9433/97 para a instituição da Política Nacional de Recursos Hídricos, um decreto presidencial estabeleceu o Comitê para Integração da Bacia Hidrográfica do rio Paraíba do Sul (CEIVAP) (PEREIRA, 2003; NORONHA, 2006). Além de tratar-se de uma bacia prioritária devido à forte urbanização e industrialização da região e por ser responsável pelo abastecimento de 14 milhões de habitantes, essa escolha se deu por tratar-se de uma das bacias nacionais mais preparadas, tanto quanto aos aspectos técnicos, quanto à mobilização social existente na região. Várias iniciativas de gestão já haviam sido instituídas nesta bacia, com diferentes formatos. São elas (PEREIRA, 2003):

- Serviço de Melhoramentos do Vale do Paraíba, por iniciativa do governo paulista, inspirado na experiência americana do Tenessee Valley Authority (TVA), descrita no item 4.3.3;

- Serviço do Vale do Paraíba, no início dos anos 1950, também como iniciativa paulista, subordinado ao DAEE;

- Comissão do Vale do Paraíba (COVAP), criada em 1968, a partir da criação da Comissão Interministerial Permanente com o objetivo de coordenar ações federais e estaduais; e

- Comitê Executivo de Estudos Integrados da Bacia Hidrográfica do Rio Paraíba do Sul (CEEIVAP), iniciativa pioneira interestadual do governo federal em planejamento de bacias hidrográficas, já citada no item 5.1.

Nesta bacia, devido à dupla dominialidade dos recursos hídricos, além de seguir os princípios e instrumentos ditados pela Lei Federal ํㅜ 9433/97, há outros três sistemas estaduais de gestão - dos Estados de Minas Gerais, Rio de Janeiro e São Paulo. Apesar de apresentarem princípios e instrumentos similares, encontram-se em estágios de implementação bem diferentes. A partir da decisão de implantação da cobrança pelo uso da água, cuja deliberação data de 6 de dezembro de 2001, foram implantados os instrumentos a ela relacionados - plano de bacia e outorga de direito de uso, e foi criada e instalada a Agência da Bacia do Rio Paraíba do Sul 
(AGEVAP). Com esse quadro, foi a primeira bacia de rio de domínio da União a atingir um estágio avançado de implantação da gestão integrada, descentralizada e participativa no Brasil (PEREIRA, 2003)

Criado através de um decreto presidencial de 2002, o Comitê das Bacias dos Rios Piracicaba, Capivari e Jundiaí (PCJ Federal) foi instalado em março de 2003.

Para os rios de dominialidade do Estado de São Paulo nesta bacia, já estava instalado, desde 1993, o Comitê da Bacia Hidrográfica dos Rios Piracicaba, Capivari e Jundiaí (CBH PCJ). Em 1987, em sua primeira reunião, o $\mathrm{CRH}$ reconheceu a bacia do Piracicaba como "área crítica na qual a gestão dos recursos hídricos deve ser feita segundo diretrizes e objetivos especiais" (ANA, 2009, p. 81). No ano seguinte, foi declarada como "modelo básico para fins de gestão de recursos hídricos" (ANA, 2009, p. 81); vários programas e projetos de despoluição e proteção das águas começaram a ser nela desenvolvidos; e foi então escolhida para a instalação do $1^{\circ}$ comitê paulista.

E, para os rios de dominialidade do Estado de Minas Gerais, foi instalado, em 2008, o Comitê das Bacias Hidrográficas do Piracicaba e Jaguari (CBH PJ), seguindo a Lei Estadual de Minas Gerais № 13199/99.

Apesar das composições serem diferentes em cada legislação, os três comitês atuam de forma integrada e contam com uma única diretoria composta por um presidente, três vice-presidentes e um secretário executivo. Graças a um acordo muito bem estruturado, dos 50 membros do comitê federal, 29 fazem também parte do comitê paulista e 9 atuam também junto ao comitê mineiro. Dessa forma, os comitês podem se reunir e deliberar em conjunto pelos três colegiados. 
Quanto à implantação dos instrumentos de gestão, o CBH PCJ é o comitê em estágio mais avançado no Estado de São Paulo, pois já conta com plano de bacia, outorga, cobrança pelo uso das águas de domínio estadual e federal e, à frente dos demais comitês paulistas, o enquadramento dos corpos d'água está em fase de aprovação. Em dezembro de 2008, os Comitês PCJ autorizaram a criação da Fundação Agência das Bacias PCJ. Até o momento, o Consórcio PCJ atuava como entidade delegatária (ANA, 2009).

Além dos 2 comitês federais citados, foram também instituídos legalmente os seguintes colegiados:

- Comitê da Bacia Hidrográfica do Rio São Francisco, localizado nos Estados de Minas Gerais, Goiás, Bahia, Pernambuco, Alagoas e Sergipe e o Distrito Federal, criado por Decreto Presidencial de 05 de junho de 2001 e instalado em 2002;

- Comitê das Sub-bacias Hidrográficas dos Rios Pomba e Muriaé, situado na Bacia Hidrográfica do rio Paraíba do Sul, englobando áreas de Minas Gerais e Rio de Janeiro, criado na mesma data - 05 de junho de 2001 - a partir da demanda dos consórcios intermunicipais regionais;

- Comitê da Bacia Hidrográfica do Rio Doce, nos Estados de Minas Gerais e Espírito Santo, instituído em 2002;

- Comitê da Bacia Hidrográfica do Rio Paranaíba, criado por Decreto Presidencial em 2002, abrangendo áreas de Goiás, Minas Gerais, Mato Grosso do Sul e do Distrito Federal;

- Comitê da Sub-bacia Hidrográfica do Rio Verde Grande, englobando áreas de Minas Gerais e Bahia, instituído em 2003; e

- Comitê da Bacia Hidrográfica do Rio Piranhas-Açu, nos Estados do Rio Grande do Norte e Paraíba, instituído em 2006 (MMA, 2008a).

Apesar de instituídos oficialmente há vários anos, alguns desses comitês ainda se encontram em fase inicial de instalação e, nos demais, poucos instrumentos de gestão ditados pela Política Nacional estão implantados. 
A cobrança pelo uso dos recursos hídricos já acontece no Comitê do Rio São Francisco, mesma bacia onde já há agência instalada, e está prevista para iniciar em 2011 no Comitê do Rio Doce (ANDREU, 2010; MACHADO, 2010).

Atualmente estão sendo implantados mais dois comitês federais:

- Comitê da Bacia Hidrográfica do Rio Grande, nos Estados de Minas Gerais e São Paulo, cuja diretoria provisória tomou posse em novembro de 2010; e

- Comitê da Bacia Hidrográfica do Rio Paranapanema, que abrange áreas de São Paulo e do Paraná.

\subsubsection{Situação atual dos Comitês de Bacias Hidrográficas Estaduais}

O início da instalação de comitês de bacia hidrográfica no país aconteceu no ano de 1988, no Rio Grande do Sul (NORONHA, 2006), anterior à promulgação da Lei $n^{\circ}$ 10350/94, que instituiu a política de recursos hídricos deste estado. Os Comitês das Bacias Sinos e Gravataí, afluentes do rio Guaíba, surgiram da própria comunidade das bacias hidrográficas, com o apoio do governo estadual. Segundo PORTO e PORTO (2008), apesar de terem inicialmente apenas atribuições consultivas, esses comitês se mostraram produtivos devido à forte mobilização e foram incorporados ao sistema estadual de gestão.

Atualmente encontram-se instalados 161 comitês em bacias de rios sob domínio estadual no Brasil (MMA, 2011). Em março de 2009 estavam implantados 148 comitês estaduais, conforme levantamento 2008/2009 realizado pela Secretaria de Recursos Hídricos e Ambiente Urbano (SRHU) do Ministério do Meio Ambiente (MMA). Ainda não há comitês nos Estados do Acre, Amapá, Maranhão, Pará, Roraima, Rondônia e Tocantins, e em alguns estados, há apenas um comitê estadual 
implantado (MMA, 2008/2009). Estes levantamentos apontam um grande avanço em relação à situação encontrada em 2004, quando haviam 87 comitês instalados em 12 estados da federação (SMA, 2004), porém, mesmo em estados com vários comitês em funcionamento atualmente, esses colegiados não abrangem todas as bacias hidrográficas existentes.

A grande maioria desses colegiados é formada por comitês estaduais, regidos pela Lei Federal no 9433/97 e pela lei das águas do seu estado, constituindo-se assim duplicidade de instituições, de instrumentos e de resoluções. Tal cenário pode vir a provocar concorrência e entraves na gestão das águas nessas bacias, devendo então merecer atenção especial dos gestores para que sejam estabelecidos níveis hierárquicos e responsabilidades visando a gestão integrada e coordenada de todos os cursos d'água da bacia (DOMINGUES e SANTOS, 2002).

Apesar da não obrigatoriedade de implantação dos diversos instrumentos de gestão em todas as bacias hidrográficas, em função de especificidades locais, segundo PORTO e PORTO (2008), a aplicação plena e concreta dos instrumentos de gestão possibilita avaliar se o sistema de gestão de recursos hídricos está implantado e qual seu grau de eficácia.

A situação da implementação dos instrumentos da política também difere muito entre os estados brasileiros. Neste mesmo levantamento 2008/2009 da SRHU/MMA, baseado no Sistema de Acompanhamento e Avaliação da Implementação da Política de Recursos Hídricos (SIAPREH), em 2008 somente 2 estados - São Paulo e Ceará - haviam instalado 5 instrumentos da política, a saber: Plano Estadual de Recursos Hídricos, Outorga, Sistemas de Informação, Fundo Estadual de Recursos Hídricos e Cobrança, porém ainda não em todas as bacias existentes. Em outros 3 estados - Paraíba, Pernambuco e Sergipe - foram instalados 4 instrumentos: Plano Estadual de Recursos Hídricos, Outorga, Sistemas 
de Informação e Fundo Estadual de Recursos Hídricos (MMA, 2008/2009).

\subsubsection{Evolução dos Comitês de Bacias Hidrográficas Paulistas}

Após a promulgação da Lei Estadual no 7663/91, teve início o processo de implantação dos Comitês de Bacias Hidrográficas nas bacias de rios de domínio estadual.

\subsection{3.a Instalação do 1ํㅡ Comitê Paulista}

O primeiro colegiado instalado no Estado de São Paulo foi o Comitê das Bacias dos rios Piracicaba, Capivari e Jundiaí (CBH PCJ) em 1993 que, devido a um histórico de lutas pela recuperação de suas bacias, apresentava grande quantidade de dados técnicos, acúmulo de estudos e encontros técnicos e várias propostas de soluções. Esses antecedentes, em conjunto com pessoal local interessado e bem informado, facilitaram imensamente a instalação do comitê (SMA, 1995).

O processo de instalação do primeiro comitê trouxe muitas lições para serem seguidas, situações para serem evitadas e também algumas dúvidas que permanecem sem resposta até o momento. Após a instalação desse comitê, essas lições foram agrupadas em um Manual de Instalação, cujos aspectos principais estão apresentados abaixo (SMA, 1995).

A primeira recomendação é a necessidade de difusão de informação sobre o sistema de gestão, a lei, com seus princípios, instrumentos e conceitos gerais, e o comitê de bacia, sua função, seus participantes e mecanismos de funcionamento. Para que um comitê cumpra seu papel de 
fórum regional de debates, é imprescindível que seus participantes estejam conscientes do seu significado e implicações.

A segunda orientação é a mobilização dos três segmentos e o contato com todos os interessados em cada um deles para garantir a representatividade de cada segmento. É importante atentar ao risco de um grupo, ou parte dele, se sobrepor aos demais, tomando decisões que desestimulem a participação da maioria.

Um dos temas polêmicos durante a formação da representação da sociedade civil foi o formato mais adequado para a participação dos usuários das águas, em especial os empresários industriais e agrícolas. $O$ próprio segmento se organizou e definiu para representação através de eleição entre as entidades representativas. Também houve dificuldade na definição de critério para escolha dos municípios com participação direta no comitê: se por localização, ou se de acordo com suas características, como os industrializados, os agrícolas, os de regiões metropolitanas.

A participação das universidades em plenário foi questionada, chegando a se pensar em restringi-la apenas às câmaras técnicas. Também se questionou se tais entidades devem fazer parte da representação da sociedade civil, uma vez que muitas delas são ligadas ao estado. Esse segmento apresenta uma grande multiplicidade de interesses, pois engloba empresários, ambientalistas, sindicatos patronais, além de universidades e centros de pesquisa (SMA, 1995).

\subsection{3.b Instalação dos demais comitês paulistas}

Entre os anos de 1994 e 2001 foram implantados os outros 20 comitês estaduais, abrangendo assim as 22 UGRHIs. Houve a união de duas delas 
- do rio Aguapeí e do rio do Peixe - em um só comitê - CBH Aguapeí e Peixe. No início da implantação do sistema, também as UGRHIs Serra da Mantiqueira e Paraíba do Sul foram unidas em um único comitê - o Paraíba do Sul / Mantiqueira e assim ficaram até 2001, quando o Comitê Serra da Mantiqueira foi instalado, separando-se do Comitê do Paraíba do Sul.

A figura 2 apresenta o mapa das UGRHIs do Estado e comitês instalados, cujos dados principais estão mostrados na tabela 1.

Esta tabela mostra a grande variação entre os comitês em diversos aspectos, tais como número de municípios participantes do comitê, área e população da bacia, e número de representantes em plenária. Nos casos de municípios que se situam em duas ou mais bacias, é necessário definir em que comitê ele irá participar. Geralmente, o município atua no comitê em cuja bacia sua sede está situada. Porém há casos em que o município participa dos dois ou mais comitês. Isto acontece, por exemplo, com os municípios de Bauru, que participa dos Comitês Tietê - Batalha e Tietê Jacaré, e de Agudos, que, além destes dois comitês, também faz parte do CBH Médio Paranapanema (SMA, 2008).

Com a implantação desses colegiados, as palavras chave do processo de gestão das águas - descentralização, participação e integração - adquirem seu real significado (ROCHA, 1998). 
Figura 2: Mapa das Unidades de Gerenciamento de Recursos Hídricos (UGRHIs) do Estado de São Paulo

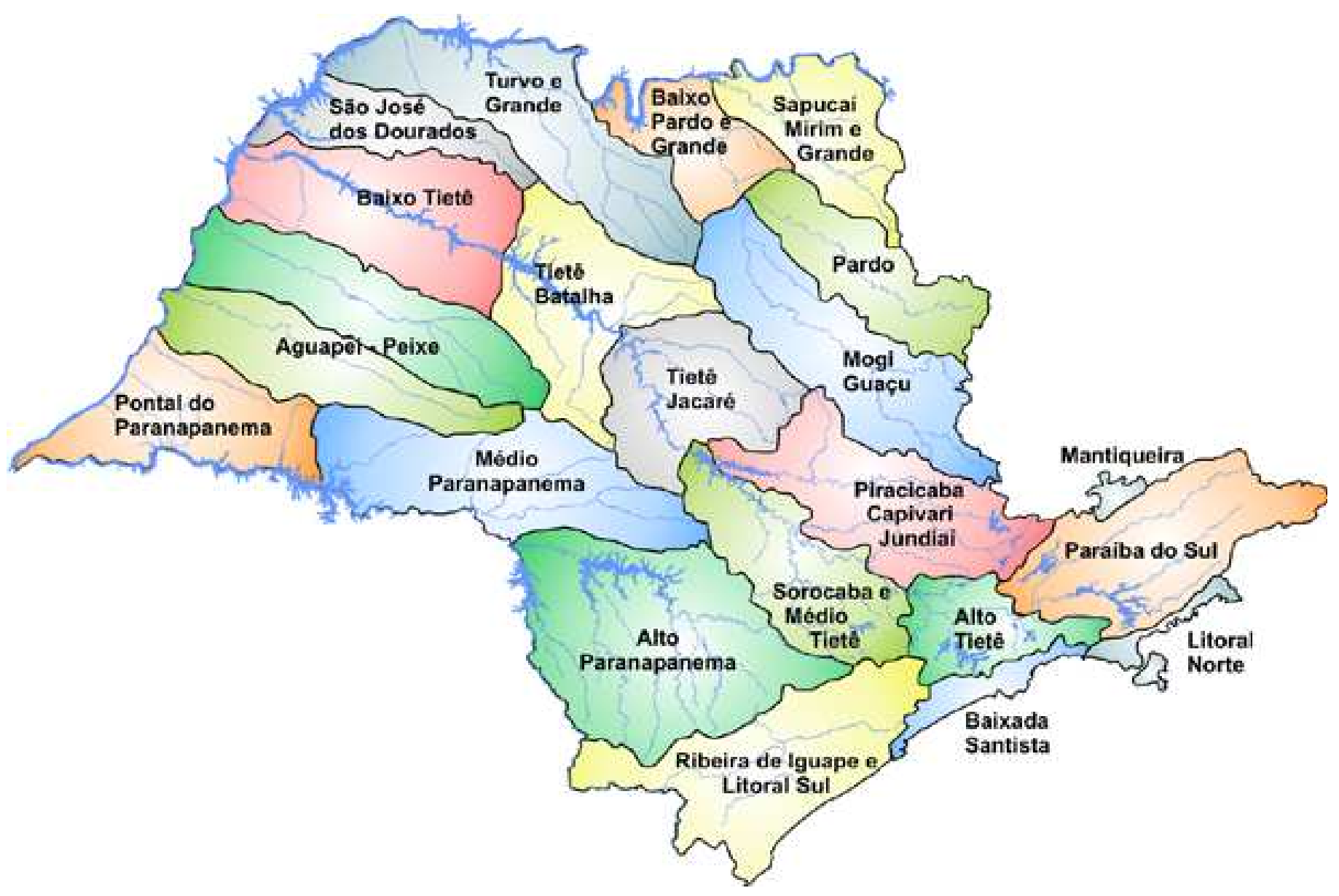

Fonte: SMA, 2008 
Tabela 1: Dados dos Comitês de Bacias Hidrográficas do Estado de São Paulo

\begin{tabular}{|c|c|c|c|c|c|c|c|c|}
\hline UGRHI & Bacias & $\begin{array}{c}\text { Sigla do } \\
\text { CBH }\end{array}$ & $\begin{array}{l}\text { Número de } \\
\text { Municípíos }\end{array}$ & $\begin{array}{l}\begin{array}{l}\text { Área * } \\
\left(\mathrm{km}^{2}\right)\end{array} \\
\end{array}$ & $\begin{array}{c}\text { População ** } \\
\text { (hab) }\end{array}$ & $\begin{array}{c}\text { Data de Instalação } \\
\text { do CBH }\end{array}$ & $\begin{array}{c}\text { Número de } \\
\text { Representantes }\end{array}$ & $\begin{array}{c}\text { Sede da Secretaria } \\
\text { Executiva }\end{array}$ \\
\hline 1 & Serra da Mantiqueira & SM & 3 & 686 & 68.529 & $29 / 06 / 2001$ & 21 & Campos do Jordão \\
\hline 2 & Paraíba do Sul & PS & 36 & 14.654 & 1.975 .456 & $25 / 11 / 1994$ & 30 & Taubaté \\
\hline 3 & Litoral Norte & LN & 4 & 1.977 & 287.470 & 02/08/1997 & 36 & Ubatuba \\
\hline 4 & Pardo & PARDO & 27 & 10.849 & 1.069 .929 & $12 / 06 / 1996$ & 39 & Ribeirão Preto \\
\hline 5 & Piracicaba, Capivari e Jundiaí & PCJ & 60 & 14.178 & 4.923 .816 & $18 / 11 / 1993$ & 51 & Piracicaba \\
\hline 6 & Alto Tietê & AT & 36 & 5.868 & 19.415 .699 & 09/11/1994 & 54 & São Paulo \\
\hline 7 & Baixada Santista & BS & 9 & 2.373 & 579.160 & 09/12/1995 & 27 & Itanhaém \\
\hline 8 & Sapucaí-Mirim / Grande & SMG & 23 & 10.873 & 683.293 & 29/03/1996 & 33 & Franca \\
\hline 9 & Mogi-Guaçu & MOGI & 38 & 13.061 & 1.438 .174 & 04/06/1996 & 42 & Pirassununga \\
\hline 10 & Sorocaba e Médio Tietê & SMT & 34 & 11.829 & 1.836 .750 & 02/0//1995 & 51 & Sorocaba \\
\hline 11 & Ribeira do Iguape e Litoral Sul & RB & 23 & 17.264 & 461.566 & $13 / 01 / 1996$ & 42 & Registro \\
\hline 12 & Baixo Pardo / Grande & BPG & 13 & 8.332 & 337.871 & 22/03/1996 & 39 & Barretos \\
\hline 13 & Tietê - Jacaré & TJ & 34 & 11.749 & 1.478 .941 & 10/11/1995 & 36 & Araraquara \\
\hline 14 & Alto Paranapanema & ALPA & 36 & 22.550 & 747.361 & $17 / 05 / 1996$ & 30 & Piraju \\
\hline 15 & Turvo / Grande & TG & 66 & 18.215 & 1.230 .678 & $1512 / 1995$ & 54 & São José do Rio Preto \\
\hline 16 & Tietê - Batalha & TB & 36 & 13.149 & 506.836 & $1309 / 1996$ & 39 & Birigui \\
\hline 17 & Médio Paranapanema & MP & 46 & 21.000 & 681.075 & 02/12/1994 & 39 & Marília \\
\hline 18 & São José dos Dourados & SJD & 26 & 6.327 & 225.133 & 07/08/1997 & 78 & São José do Rio Preto \\
\hline 19 & Baixo Tietê & BT & 42 & 15.588 & 732.486 & $26 / 08 / 1994$ & 45 & Birigui \\
\hline $20 / 21$ & Aguapeí e Peixe & AP & 74 & 28.684 & 815.512 & 19/12/1995 & 42 & Marília \\
\hline 22 & Pontal do Paranapanema & PP & 26 & 17.159 & 487.754 & $21 / 06 / 1996$ & 39 & Presidente Prudente \\
\hline
\end{tabular}

Fonte: Elaborado pela autora (2011) com dados SMA (2008), exceto área e população de SMA (2009a)

Notas: * Área - Plano Estadual de Recursos Hídricos - PERH, 2005 (SMA, 2009a)

** População - Fundação Sistema Estadual de Análise de Dados - SEADE, 2007 (SMA, 2009a) 


\subsection{3.c Avaliações do SIGRH}

Em 1995, foi feita uma pesquisa qualitativa junto a 17 representantes de alguma das instâncias do sistema - $\mathrm{CBH}$ PCJ, $\mathrm{CRH}$ ou Conselho de Orientação do Fundo Estadual de Recursos Hídricos (COFEHIDRO) com o objetivo de verificar as circunstâncias e os resultados do processo político e institucional vivido pelos representantes do governo paulista, dos municípios e da sociedade civil. A proposta foi analisar a percepção desse grupo através da aplicação de questionário montado a partir de pressupostos teóricos. Algumas das constatações efetuadas nesta pesquisa estão apresentadas no item 5.6, separadas conforme assunto correspondente. Dentre as constatações sobre aspectos gerais, cabe ressaltar:

- Os técnicos do DAEE foram apontados como impulsionadores desse processo;

- A participação dos demais representantes, mesmo do segmento estado, foi pequena;

- É necessária mudança de postura por parte dos três segmentos, pois sempre agiram setorialmente, de forma estanque;

- Há receio dos municípios menores serem ofuscados pelos maiores; e

- Mudanças de gestão a cada 4 anos causam preocupação (SMA, 1995).

Passados 5 anos de vigência da Política Estadual de Recursos Hídricos, ROCHA (1998) constatou que grandes avanços em relação ao passado já haviam sido obtidos e destacou:

- Criação de espaços institucionais abertos, descentralizados, que possibilitam a integração regional dos órgãos e entidades governamentais e não governamentais que, antes, atuavam de forma isolada; 
- Inclusão de novos atores no processo de decisão, participando da busca de soluções mais adequadas para os problemas locais e também fiscalizando os órgãos do governo;

- Maior publicização dos assuntos e dos problemas ligados a recursos hídricos; e

- Maior possibilidade de neutralização das práticas clientelistas entre prefeitos e lideranças locais e os governantes estaduais.

O autor destacou também alguns aspectos negativos observados neste período:

- Dificuldade de alguns órgãos e entidades, especialmente do poder público estadual, para ceder espaço aos novos atores;

- Concentração de conhecimento técnico entre os representantes estaduais; e

- Despreparo das organizações não governamentais.

Em 2010, a consultoria Empinotti Ambiental realizou a Avaliação dos 20 anos do Sistema Integrado de Gerenciamento de Recursos Hídricos SIGRH, sob a coordenação da Coordenadoria de Recursos Hídricos (CRHi) da Secretaria do Meio Ambiente do Estado de São Paulo (SMA). Com o objetivo de identificar avanços e problemas do sistema a partir da perspectiva dos atores do próprio sistema, para possibilitar seu fortalecimento e alcançar maior eficiência das ações do Estado na gestão dos recursos hídricos, foram realizadas entrevistas com 33 representantes que atuam pelos três segmentos - 12 pelo Estado, 11 pelos Municípios e 10 pela Sociedade Civil. A análise dos resultados dessas entrevistas está apresentada em um relatório onde consta também comparação com resultados alcançados em avaliações anteriores (EMPINOTTI, 2010). Dentre os diversos aspectos avaliados, é importante salientar os resultados sobre os instrumentos Planos de Recursos Hídricos e Cobrança, bem como sobre Comunicação, Articulação e Integração externa e interna ao SIGRH e sobre o 
funcionamento dos colegiados no sistema, que estão apresentados no item 5.6, separados por assunto. No geral, os colegiados foram avaliados de forma positiva pelos três segmentos como "espaços de negociação coerentes, dando exemplos de transparência e descentralização da gestão" (EMPINOTTI, 2010, p. 90). Foi, porém, apontado que, durante o período eleitoral, os comitês ficam inertes.

\subsection{3.d Considerações sobre os comitês paulistas}

Para a formação dos colegiados, em geral, os representantes dos segmentos do poder público são indicados pelos dirigentes dos respectivos órgãos de governo que atuam na bacia, e a representação do segmento da sociedade civil se dá de maneira espontânea: as entidades se cadastram junto à secretaria executiva do comitê em questão, seguindo regras fixadas por uma comissão eleitoral, e são classificadas por segmento, tais como: associações científicas; associações técnicas ligadas a recursos hídricos; associações de defesa do meio ambiente; usuários da água para abastecimento público; usuários agrícolas da água; usuários da água para comércio, lazer e serviços; usuários industriais; e organizações sindicais vinculadas a recursos hídricos, saneamento e meio ambiente. Nos casos em que os inscritos ultrapassem o número de vagas estipulado pelo comitê para aquele setor, é feita uma eleição interna entre os pares (CAMPOS, 2005).

Para a formação da diretoria, no primeiro comitê instalado no Estado - o CBH PCJ, acordou-se que:

- "o segmento dos prefeitos escolhe o presidente, simbolizando a descentralização;

- o segmento sociedade civil elege o vice-presidente, sinalizando para a participação; e 
- o segmento Estado indica o secretário executivo porque detém maior conhecimento e informação sobre os recursos hídricos" (ROCHA, 1998, p.7).

Esse acordo acabou sendo seguido pelos demais colegiados do Estado, trazendo uma homogeneidade no Estado de São Paulo, vista como uma resistência do poder público em "dividir com a sociedade civil a responsabilidade pela gestão das águas no Estado" (FREITAS, 2000, p. 73). Uma exceção importante à época se deu no Comitê da Bacia Hidrográfica do Tietê - Jacaré (CBH TJ), onde, por consenso, "foi decidido que a sociedade civil assumiria a presidência, um representante de município a vice-presidência, e a secretaria executiva permaneceria representada por um órgão do Estado" (ASSIS e SALVADOR, 1998, p. 89). Esse caso foi considerado importante por quebrar essa homogeneidade sobre qual segmento ocupa cargo na direção do comitê que, apesar de não instituído por lei, poderia causar uma divisão estanque de papéis e estabelecer status diferenciado entre os diferentes segmentos no comitê (ASSIS e SALVADOR, 1998; FREITAS, 2000). Atualmente, na gestão 2011 - 2013, isto também acontece no CBH Paraíba do Sul, no qual um representante da sociedade civil ocupa o cargo de presidente e uma prefeita, o de vice-presidente (CBH PS, 2011).

Decorridos 19 anos da promulgação da Lei Estadual no 7663/91, são encontradas grandes diferenças entre os 21 comitês instalados. Além das já citadas no item 5.5.3.b, é importante verificar as diferenças na estrutura desses colegiados. Devido à autonomia dada aos comitês para criar câmaras técnicas, como também grupos de trabalho ou comissões especiais, em função da necessidade de sua bacia, existe atualmente desde um comitê, o CBH São José dos Dourados, com apenas uma câmara técnica instalada, até outro, o CBH PCJ, com 12 câmaras técnicas em funcionamento ativo. As câmaras técnicas mais comuns são de Planejamento e Gestão, de Assuntos Institucionais e de Saneamento, e, entre os grupos de trabalho, o de Cobrança é o mais encontrado. Cabe 
ressaltar também a excepcionalidade do $\mathrm{CBH}$ Alto Tietê, devido à subdivisão em 5 subcomitês, atuando em cada sub-bacia, a saber, Billings - Tamanduateí, Cabeceiras, Cotia - Guarapiranga, Juqueri Cantareira e Pinheiros - Pirapora.

Além das diferenças de estrutura apontadas, há atualmente grande defasagem no estágio de implantação dos instrumentos de gestão nas 22 UGRHIs do Estado de São Paulo. Ao analisar a situação atual de um desses instrumentos - a cobrança pelo uso da água, encontra-se a seguinte situação (SMA, 2010; SMA, 2011):

- Implantação em 2 bacias - Paraíba do Sul e Piracicaba, Capivari e Jundiaí - para recursos hídricos de domínio federal e estadual;

- Início do pagamento pelos usos urbanos e industriais no $2^{0}$ semestre de 2010 na bacia dos rios Sorocaba e Médio Tietê para recursos hídricos de domínio estadual;

- Assinatura do decreto estadual de implantação da cobrança pelos usos urbanos e industriais em 5 bacias: Alto Tietê, Baixada Santista, Baixo Tietê, Tietê - Batalha e Tietê - Jacaré, em dezembro de 2010;

- Usos urbanos nas demais bacias ainda não cobrados; e

- Cobrança pelos usos rurais das águas de rios de domínio estadual ainda não regulamentada.

\subsection{DESAFIOS DO ATUAL SISTEMA DE GESTÃO DE RECURSOS HÍDRICOS DO BRASIL}

Textos e artigos levantados sobre comitês de bacia, tanto do Estado de São Paulo como nos demais, como também as avaliações descritas no item 5.5.3.c, apontam para os avanços atingidos pelo atual sistema de gestão de recursos hídricos e alertam para uma série de problemas neles encontrados. Alguns desses se repetem em várias bacias e são trazidos por vários autores, como será mostrado a seguir. Para a 
operacionalização do sistema de gestão instituído pela legislação e a implantação completa dos instrumentos de gestão nas bacias hidrográficas, é necessário vencer esses desafios.

\subsubsection{Adoção da bacia hidrográfica como unidade de gestão}

Um dos princípios inquestionáveis do atual sistema de gestão das águas, adotado por muitos países e universalmente reconhecido, é a concepção da bacia hidrográfica como unidade de gestão. "Ao instituir a bacia hidrográfica como unidade de planejamento e gestão", segundo PEREIRA (2003), "busca-se superar uma lógica puramente setorial, que tem dominado a gestão das águas no Brasil, e criar uma lógica territorial de gestão integrada dos usos múltiplos. É de grande importância que os setores usuários sejam eficientes na sua lógica setorial, mas subordinados a uma lógica global de gerenciamento dos recursos hídricos" (p. 15). Esse território, segundo CARDOSO (2003) pode ser visto como "possuidor de um arcabouço institucional próprio para administração e deliberação sobre o uso dos recursos hídricos" (p. 70) e considerado como "algo dado, que simplesmente as pessoas tem que compreender o que é para poder se apropriar da política de gestão" ( $p$. 70).

TUCCI (1987) explica que:

"Quando o técnico depara com o planejamento e gerenciamento da água, dois condicionantes básicos aparecem: o meio onde o recurso se distribui, que é a bacia hidrográfica; e aquele onde o mesmo é utilizado, que são as concentrações urbanas e algumas áreas rurais. Historicamente, as populações tem ocupado as margens dos rios principais, que eram e são utilizados como meio de transporte, abastecimento d'água e diluição de efluentes. O rio também tem sido um divisor geográfico, pela facilidade de demarcação topográfica de países, Estados e até propriedades particulares. Portanto, a água e seu uso nem sempre se distribuem no mesmo espaço, criando um complicador adicional" (p. 213). 
Esse complicador é a dificuldade de conciliar os limites da bacia, determinados pelos divisores de água, com as divisas políticoadministrativas, ou seja, a divisão por estados e municípios, unidades administrativa e politicamente fortes no Brasil (ALVIM, 2003; CARDOSO, 2003; MIYASHITA, 1998; MMA, 2009a; SMA, 1995). Na França, país que serviu de modelo para nosso sistema de gestão, o estado é mais centralizado e as províncias detém pouco poder, não acarretando assim disputa de poder com os comitês e as agências de bacias, detentores de grande força política no âmbito regional (CARDOSO, 2003).

ALVIM (2003) constata que "no modelo de gestão integrada de bacia hidrográfica, apesar da unidade de gestão ser a bacia hidrográfica, é no nível do município e do conjunto deles, que a aplicabilidade das políticas acontecem" (p. 41). Torna-se necessária a integração de políticas públicas para a implementação de ações conjuntas visando o uso, a conservação e a recuperação das águas (MMA, 2009a). Cabe também citar as situações em que municípios e setores funcionais atuam em mais de um colegiado de bacias, o que, na sua opinião, amplia as possibilidades de articulação institucional, setorial e entre bacias vizinhas. A autora alerta também para a necessidade de se contemplar conjunto de bacias nos casos de reversões de água entre bacias (ALVIM, 2003).

No Estado de São Paulo, ao definir a divisão em 22 UGRHIs já descrita no item 5.4, "os responsáveis pela administração das águas e da divisão espacial do Estado (...) fizeram uma mescla entre bacia hidrográfica e região administrativa" (MARIANO, 1996, p. 10), desrespeitando o conceito de bacia hidrográfica como unidade de gestão. Mesmo assim, neste estado há municípios cujas áreas se encontram em até três bacias diferentes, como já citado no item 5.5.3.b; como também há instituições com duas ou mais regionais atuando em uma mesma bacia. Essa questão apareceu durante a pesquisa feita em 1995 junto a 17 representantes do sistema, apresentada no item 5.5.3.c. Apesar da 
adoção da bacia hidrográfica como unidade de gerenciamento ter sido aceita por consenso quase absoluto, foi detectada a dificuldade dos prefeitos assimilarem seu significado, como também a existência de outra divisão de bacias diferente da adotada pelo sistema (SMA, 1995). Observou-se, naquela ocasião, que mesmo os organismos ligados a recursos hídricos que adotavam a bacia hidrográfica como unidade de gestão, apresentavam limites diferentes para suas unidades de atuação (ALVIM, 2003). Durante pesquisa realizada na bacia Tietê - Jacaré, FREITAS (2000) constatou a situação delicada dos municípios que possuem parte de seus territórios em mais de uma bacia e questionou: "Como eles poderão adotar as decisões de um determinado Comitê, se seus domínios abrangem outros?" (p.103-104).

Essa questão voltou a ser levantada durante a Avaliação dos 20 anos do Sistema Integrado de Gerenciamento de Recursos Hídricos - SIGRH, com a sugestão para que os limites das UGRHIs fossem adotados pelo governo para a regionalização de suas secretarias (EMPINOTTI, 2010).

CARDOSO (2003) lembra que os problemas relacionados à água, tais como escassez de água, contaminação dos rios, uso abusivo para fins agrícolas ou industriais, não ficam restritos aos limites da bacia, como também não se configuram por estes limites as alianças políticas, as identidades sociais e a atuação das instituições. Sendo assim, "a referência da bacia terá necessariamente que ser construída e disputada com as unidades e percepções já existentes" (p. 71).

Outro aspecto a destacar é a diferença entre reconhecer a bacia hidrográfica e se identificar com ela. "Há bacias hidrográficas que envolvem dezenas de municípios, muitas vezes sem nenhum laço que os una" (CARDOSO, 2003, p. 72). 
5.6.2 Participação pública no planejamento e na tomada de decisão

Até a implementação do SIGRH, a sociedade civil e os municípios foram alijados do processo decisório relacionado à gestão dos recursos hídricos, sendo que a atuação dos municípios até a década de 1980 limitou-se às questões de saneamento básico (SMA, 1995). A descentralização do poder estabelecida pela Constituição Federal de 1988 é considerada fundamental por REBOUÇAS (1999) para propiciar ao país, rapidamente, arcabouço legal indispensável para enfrentar problemas emergentes em bacias hidrográficas críticas. Segundo o autor:

"A participação da sociedade é importante, para o desenvolvimento de novos valores que ajudem os indivíduos e as organizações públicas e privadas a enfrentar as realidades sociais, ambientais e de desenvolvimento que se encontram em rápida transformação. $O$ que a sociedade precisa é de estímulo à participação na definição das prioridades e na forma como elas se inserem num plano de conjunto que se desdobra ao longo do tempo. Só assim poderemos ter a discussão democrática que é o oposto da manipulação, ou do tradicional paternalismo do Estado. Assim, obtem-se o compromisso e a ação dos cidadãos, base da legitimidade de todo o poder" (p. 35).

MIYASHITA (1998) observou, ao analisar a experiência internacional de gerenciamento de recursos hídricos, que, em grande parte dos países analisados, "o papel da participação dos usuários está sedimentada ao longo de séculos de cidadania garantida e reiteradamente exercida, que, muitas vezes, transcende a questão hídrica" (p. 2).

Porém, conforme já relatado no item 5.5.3, a implantação desse sistema encontrou dificuldades para a inclusão dos novos atores no processo de decisão. Isso ocorreu, em especial, devido à resistência de alguns órgãos estaduais para ceder espaço a esses novos atores (ROCHA, 1998), como também ao risco de alguns participantes se sobreporem aos demais ou de municípios menores serem ofuscados pelos maiores, desestimulando assim a participação da maioria (SMA, 1995). 
Durante as negociações para definição do estatuto do Conselho Estadual de Recursos Hídricos $(\mathrm{CRH})$, "a incapacidade de definir uma proposta politicamente consistente" em relação ao voto da sociedade civil, "indica que as questões da democratização, da paridade, da equidade e da descentralização do processo decisório são difíceis de serem assimiladas pelos diversos órgãos estaduais" (SMA, 1995, p. 25).

Numa das entrevistas realizadas durante a pesquisa de 1995, obteve-se 0 depoimento positivo de um dos participantes: "A gente conseguiu aprovar o projeto - não, evidentemente, da forma que a gente queria, na sua plenitude -, mas foi o consenso possível entre as pessoas que participaram dessa discussão" (SMA, 1995, p. 57). Entretanto, foram também apontados dois pontos negativos em relação à tomada de decisão:

- Houve percepção de que "a pauta já vem fechada e não é discutida" (p. 57), questionando-se assim a forma não democrática de encaminhamento das discussões, que deveriam ser mais abertas; e

- Dirigentes das entidades estatais são centralizadores (SMA, 1995).

O primeiro deles também foi constatado por NEDER (2000) ao longo de quase dois anos de convivência em comitês, ao ouvir reações de representantes que constataram que, "no momento de tomar decisões sobre recursos, aplicações, obras e intervenções diversas, no interior dos meandros do circuito executivo de governo e interesses privados, muitas dessas decisões já chegaram prontas ao Comitê, ou apenas são apresentadas a título formal para discussão e aprovação por voto da maioria" (p. 50).

Essa dificuldade ainda persiste, pois, durante a Avaliação dos 20 anos do SIGRH, foi levantado que o Estado ainda exerce um papel autoritário e centralizador na tomada de decisão, enfraquecendo assim o sistema 
(EMPINOTTI, 2010). "A forma como o Estado participa ou participou nestes últimos anos da administração pública tem que ser revista (...) e a direção é a descentralização" (SMA, 1995, p. 59). Os representantes apontaram que:

- O Estado já traz os materiais prontos para serem discutidos e a Sociedade Civil não tem como influenciar a tomada de decisão, por ser minoria; e

- O Estado ainda exerce um papel autoritário e centralizador na tomada de decisão, enfraquecendo assim o sistema (EMPINOTTI, 2010).

O objetivo do processo decisório participativo é escolher, perante um problema de ordem coletiva, a solução a ser implementada atendendo ao desejo da maior parte da comunidade envolvida. "Identificar o atendimento das demandas por maioria da população, é critério sempre importante em todas as áreas" (ROESLER e CENCI, 2010, p. 9).

Outro aspecto já abordado na Introdução e no item 4.4 é o tempo necessário à tomada de decisão por meio de processo participativo. Esta tende a ser mais demorada que decisões tomadas unilateralmente, porém tende a ser mais facilmente implantada (PORTO e PORTO, 2008; HARMONICOP, 2005). MARIANO (1996) traz o relato de um conselheiro do CBH PCJ que, somente com a participação social, o sistema de gestão poderá produzir resultados rápidos e garantir "durabilidade, permanência e eficácia ao novo sistema" (p. 102).

As reuniões dos comitês de bacia, em especial as plenárias, devem ser planejadas antecipadamente com muito cuidado, atentando-se à necessidade de envio antecipado do material a ser debatido a todos os membros, conforme estipulado no estatuto do comitê. Sua condução deve ser feita de maneira firme o suficiente para que não se desvie do foco, porém com certa liberdade para possibilitar uma discussão rica com a participação de todos. GRANZIERA (2001) lembra que: 
"A questão que se coloca é que os envolvidos com a questão dos recursos hídricos, não agindo de boa-fé, podem simplesmente paralisar todo e qualquer esforço legislativo, regulamentador, controlador.

Uma reunião de Comitê de Bacia Hidrográfica pode produzir efeitos marcantes, em que se decidem os rumos a ser dados aos recursos hídricos, ou ser apenas uma reunião burocrática, em que o desacordo político impede a tomada de decisões técnicas" (p. 168).

Cabe citar OLIVI (2004) ao ressaltar que "o sucesso e a eficácia da existência da Política Francesa de Recursos Hídricos devem-se ao fato de que todos os interessados pela questão hídrica efetivamente e democraticamente participam de seus comitês" (p. 95). Para se obter resultado semelhante nos comitês brasileiros, é necessário atentar aos aspectos tratados nos itens a seguir.

\subsubsection{Condições de participação dos membros dos comitês}

Apesar do reconhecimento da importância da participação da sociedade na gestão de recursos hídricos, além dos desafios já apontados acima, ainda há dificuldades de ordem prática a serem vencidas pelos membros dos comitês, em especial da sociedade civil, pois "a participação ativa e voluntária custa tempo e esforço" (MARIANO, 1996, p. 72). NEDER (2000) ressalta, dentre vários aspectos levantados em uma avaliação realizada pela SMA em 1997, que "a maioria das entidades civis atuantes com representação social (usuários domésticos) não dispõe de infraestrutura que permita a participação de seus representantes" (p. 33). Essa infra-estrutura citada engloba as despesas necessárias para os deslocamentos a cidades diferentes que, em alguns casos, envolve grandes distâncias ou, em outros, são cidades pequenas, para as quais o transporte coletivo não é facilmente disponibilizado. Além dos deslocamentos, também é necessário cobrir despesas de alimentação e, em casos especiais, de pernoite. O autor ressalta a dificuldade das entidades populares para acompanhar as diversas formas de negociação 
nas diferentes instâncias que, em alguns casos, envolve câmaras técnicas, plenárias, reuniões extraordinárias, encontros de sensibilização e audiências públicas, e afirma que "cumprir esta agenda é frequentemente custoso" (p. 48).

Durante pesquisa efetuada no CBH TJ, OLIVI (2004) relata problemas de falta de capacitação técnica e falta de tempo em reunião ocorrida para análise e classificação de projetos inscritos para financiamento com verbas do FEHIDRO, "uma vez que os integrantes do $\mathrm{CBH}$ TJ são pessoas voluntárias e, desta forma, trabalham para a causa ambiental hídrica, com o tempo que Ihes sobra após suas atividades profissionais, sem capacitação adequada para tal exercício e sem os recursos financeiros e materiais adequados" (p. 70). Como já apontado no item 4.4, MARIANO (1996) traz a sugestão feita por representante junto ao Conselho Nacional do Meio Ambiente (CONAMA) para a remuneração dos representantes da sociedade civil por "ser um serviço relevante à nação" (p. 120), mas também aponta o receio apresentado de tal procedimento "desvirtuar o verdadeiro sentido da participação popular, que é o de coadjuvante do processo decisório, transformando essa participação numa profissão" (p. 120). Cabe citar que tal prática é realidade no Conselho Nacional de Recursos Hídricos, uma vez que os membros da sociedade civil recebem apoio financeiro para participar das atividades deste conselho (MMA, 2008b).

\subsubsection{Composição dos comitês}

Segundo a Lei Estadual $\mathrm{n}^{\circ}$ 7663/91, os comitês de bacia devem assegurar a participação paritária dos municípios em relação ao estado, bem como respeitar o limite máximo de um terço do número total de votos para os representantes de entidades da sociedade civil, sediadas na bacia hidrográfica (DAEE, 2006). 
GRANZIERA (2001), porém, adverte que a Lei "é apenas um passo inicial para que ocorra, de fato, o gerenciamento, com vista em alcançar os princípios e objetivos propostos. O fato de os usuários e da sociedade civil, e também dos municípios, participarem dos comitês é a única condição capaz de garantir comprometimento de cada um com o processo. Sem isso, não há como ser efetiva a lei" (p. 168).

Apesar da afirmação que "a paridade é uma questão fundamental e o princípio da Lei no 7663/91" (SMA, 1995, p. 76), ela é questionada por diversos atores do sistema e autores. A Avaliação dos 20 anos do SIGRH, citada no item 5.5.3.c, apontou, como uma de suas conclusões, que a representação não é tripartite, isto é, não há equilíbrio entre o número de representantes do poder público (Municípios e Estado), dos usuários e das organizações da Sociedade Civil (EMPINOTTI, 2010, p.90).

Os comitês de bacia de rios de domínio federal, bem como os comitês de outros estados brasileiros, apresentam representações diversas da dos comitês paulistas. Conforme citado no item 5.2, a Lei Federal no 9433/97 define, no inciso $1^{\circ}$ do artigo 39 , que a representação dos poderes executivos dos três níveis - União, Estados e Municípios - está limitada à metade do total de membros dos comitês (BRASIL, 1997). Porém, a Resolução ํㅡ 5/00, do CNRH, ao estabelecer diretrizes para a formação e funcionamento dos comitês, restringe a representação do poder público a $40 \%$ dos votos. Além disso, esta Resolução também limita a participação dos usuários das águas a $40 \%$ dos votos, e a das entidades civis de recursos hídricos, ao mínimo de $20 \%$ dos votos (MMA, 2008a).

A composição adotada pelos comitês paulistas, segundo FREITAS (2000), "não observa ao disposto na Lei Federal sobre o limite máximo de participantes do Poder Público dentro destes, o que a torna ilegal" (p. 106). Tal conflito de legislações também é apontado por SOUZA (2000), ao afirmar que, "no que tange à participação da sociedade, um bom princípio 
seria os conselhos e os comitês observarem a composição definida na Política Nacional (...), e não ficarem atendendo os casuísmos das legislações estaduais, em uma postura contrária ao disposto em lei" (p. 95) e por OLIVI (2004), que ressalta a necessidade da Lei Estadual ํㅜ 7663/91 ajustar-se à Lei Federal no 9433/97.

Durante a pesquisa realizada em 1995, apresentada no item 5.5.3.c, foi também constatada a necessidade de compatibilização das legislações estaduais, e das legislações estaduais com a federal, além de ter sido constatada a ausência de representação do governo federal nos comitês paulistas (SMA, 1995).

Uma grande diferença observada é o segmento de usuários, existente na legislação federal e na de vários estados, e ausente na legislação paulista. No Estado de São Paulo, a maior parte dos usuários participa pelo segmento Sociedade Civil, sempre através de associações, e, quando há divisão de vagas definida no estatuto, tais associações são classificadas em categorias conforme o uso, tais como: usuários urbanos ou domésticos, usuários rurais, usuários industriais, usuários comerciais, de lazer e de serviços. Além disso, apesar de ser um grande usuário urbano, a companhia estatal de saneamento atua pelo segmento Estado. Outra diferença importante apontada por FREITAS (2000), é que "no Estado do Rio Grande do Sul as prefeituras fazem parte da classe de usuários da água, por terem a responsabilidade pela gestão das Empresas de Tratamento de Água" (p. 82).

A pesquisa realizada pela SMA em 1995 também apontou que, apesar da dificuldade em se representar, os representantes da sociedade civil conquistaram legitimidade junto aos demais participantes, e que a participação dos usuários deveria ser aumentada, mas não por entidades de classe (SMA, 1995). 
Neste aspecto, GRANZIERA (2001) afirma, ao referir-se ao sistema decisório de cada comitê, que "há que haver representatividade de todos os setores interessados, assim como da sociedade civil (...), sobretudo no tocante aos usuários” (p. 189). É necessário avaliar cada caso, pois o segmento da sociedade civil é o que apresenta maior variação quanto às entidades envolvidas, pois estas variam em função das atividades econômicas e sociais predominantes na região em que se situam. Os setores produtivos, frequentemente, apresentam um nível de mobilização, de organização e de proposições mais definidos em relação ao dos representantes de outros setores da sociedade civil, em geral com menor mobilização. É importante considerar que:

"A sociedade civil é um segmento heterogêneo, apresentando diversidade de organização e interesses. A união entre as entidades é extremamente circunstancial, havendo, naturalmente, aliados preferenciais, mas podem ocorrer surpresas nas alianças. As entidades ambientalistas constituem o setor mais diferenciado quanto à forma de organização e ação. A tendência dos entrevistados é querer que essas entidades ajam de acordo com os demais setores" (SMA, 1995, p. 81-82).

NEDER (2000) aponta como uma das origens dos problemas de articulação nos comitês a composição da sociedade civil não-econômica, devido a sua heterogeneidade e a sua fragmentação. Afirma ainda que "a coordenação da representação social é um ponto crítico" (p. 48), pois tais grupos são desorganizados e têm baixa capacidade de coordenação estratégica. MARIANO (1996) constata, ao entrevistar membros do CONSEMA e do CBH PCJ, uma desorganização da sociedade civil, em especial das entidades ambientalistas, apesar destas terem sido apontadas como bem participativas, terem posicionamento firme e refletirem os anseios da população. A autora aponta ainda "uma distorção quantitativa na participação das entidades ambientalistas representantes da grande maioria da população usuária das águas" (p. 84), pois na formação inicial do CBH PCJ, das 16 vagas da sociedade civil, 8 são para usuários de água, 2 para universidades regionais, 2 para 
entidades de classe e apenas 4 para entidades ambientalistas. E complementa que "esta mescla de representações não significa que a sociedade civil esteja representada" (p. 84).

Durante os trabalhos do Grupo Executivo que formulou o Regimento Interno para o funcionamento do $\mathrm{CRH}$, foram encontradas grandes dificuldades para decidir pelo número de participantes adequado, de forma a propiciar agilidade às reuniões, mas sem excluir instituição ou membro representativo. Também foi muito discutido como deveria ser a forma de escolha desses representantes (SMA, 1995).

Como relatado no item 5.5.3.a, durante a instalação do CBH PCJ, 0 mesmo aconteceu em relação ao segmento Municípios. Uma vez definido o número de representantes, foi necessário definir o critério de escolha dos municípios com participação direta no comitê. A participação das universidades no segmento sociedade civil também foi motivo de atenção, pois algumas delas estão ligadas ao governo estadual.

\subsubsection{Representatividade das entidades}

Dentre os grandes desafios apontados pela ANA (2009) a ser equacionados para a devida implantação do Sistema Nacional de Gerenciamento de Recursos Hídricos está a questão da representatividade e da representação. "A observância da representatividade e representação dos membros dos comitês de bacias conduzirá ao fortalecimento desses colegiados e a efetivação das metas pactuadas no plano de recursos hídricos" (p. 37).

Nesse sentido, NEDER (2000) apresenta o seguinte questionamento: "Como definir a qualidade da relação entre o representante e o segmento social para quem está dirigida a representação? E uma vez resolvido essa 
dimensão da qualidade do vínculo (representatividade) ressurge 0 problema da identidade coletiva à qual se atribui a representação" (p. 49). O autor salienta a necessidade de distinguir o que é representatividade (individual), tratada no próximo item deste trabalho como representatividade dos representantes, e identidade coletiva (do segmento), tratada neste item como representatividade das entidades. Esta última representa o reconhecimento coletivo da relevância do trabalho realizado por uma certa associação, organização ou sindicato entre o grupo de entidades similares.

$\mathrm{Na}$ Edição comemorativa de 10 anos de atuação do $\mathrm{CNRH}$, essa questão é levantada, ao relatar que "a dificuldade não estaria na escolha desses representantes e sim na forma como esses conselheiros fazem com que a informação percorra a todos que eles representam. Interpretar desejos e anseios de seus pares exercita a representatividade e legitima a indicação. Esse caminho de comunicação ainda apresenta dificuldades" (MMA, 2008b, p. 16).

MARIANO (1996) aponta, em pesquisa sobre a análise da participação da sociedade civil na gestão de recursos hídricos, questionamento sobre "o quanto é representada a sociedade, lembrando que na maioria das vezes a representação é particular e não social" (p. 103). Constata que a discussão prévia dos assuntos dentro do segmento representado não é um procedimento de rotina e traz o depoimento de um entrevistado: "o comum é a auto-representação que pode trazer maior liberdade de decisão por parte do conselheiro, mas pode, também, ser um entrave na hora de tomar uma decisão" (p. 107). A autora também aponta que "entidades tidas como da sociedade civil (...) podem estar falando em nome da sociedade civil, mas defendendo posições de grupos minoritários" (p. 103). 
Em 2010, a consultoria Empinotti Ambiental, após as entrevistas com 33 membros atuantes no SIGRH, apresentou quatro conclusões relativas à representatividade das entidades, a saber:

- Há preocupação quanto à qualidade da representação dos membros nos colegiados e à falta de renovação dos mesmos, inclusive dos secretários executivos e da sociedade civil, visto que hoje há entidades novas aptas a participar também;

- Os representantes da sociedade civil representam apenas um grupo limitado, e não todo o segmento;

- A participação dos prefeitos é problemática, pois só aparecem para decisões sobre recursos; e

- A participação limitada dos prefeitos nos colegiados é reconhecida até mesmo pelos representantes dos municípios (EMPINOTTI, 2010).

A necessidade de renovação também é apontada na avaliação dos 10 anos do CNRH, onde consta que "não deve haver cadeiras cativas" mas sim que as entidades da sociedade civil "possam se alternar como membros das câmaras e do Conselho" (MMA, 2008b, p. 20). Quanto à participação dos municípios, "é fundamental o fortalecimento da representação municipal nos comitês de bacia hidrográfica, espaço de diálogo, negociação e deliberação sobre os rumos da Política de águas", visto que "é no município que os problemas e conflitos relacionados com a água acontecem, as políticas públicas são executadas, as pessoas vivem e exercem sua cidadania" (MMA, 2009a, p. 3).

\subsubsection{Representatividade dos representantes}

Em 1995, a pesquisa apresentada pela SMA apontou problemas causados pela inexistência de uma relação estreita entre a cúpula e os técnicos em alguns órgãos estaduais, onde "houve grande dificuldade 
para estabelecer um fluxo de informações na direção das regionais descentralizadas" (SMA, 1995, p.81). O mesmo aconteceu em organizações da sociedade civil que têm regionais no interior. Em alguns casos, foi constatado que as decisões tomadas pela sociedade civil não refletem de fato a vontade da maioria, isto é, há possibilidade de manipulação muito grande. Também foram detectados problemas na representação dos municípios, "cujos prefeitos nem sempre deixam seus técnicos a par dos encaminhamentos e discussões" (SMA, 1995, p. 81).

Quanto à representação do segmento Estado, MARIANO (1996) traz relatos de entrevistados da sociedade civil sobre casos de "manipulação que o governo exerce em seus representantes" (p. 108) ao imporem uma decisão por ocasião de votação ocorrida no CONSEMA.

Ao avaliar os problemas relacionados à representação social, NEDER (2000) comenta sobre a insegurança que os representantes em instâncias públicas possam ter, algumas vezes, sobre sua própria representatividade, perguntando-se, em seu íntimo: "Mas estarei mesmo sendo representativo da minha categoria, entidade, segmento profissional...?" (p. 49).

A pesquisa realizada pela consultoria Empinotti Ambiental, coordenada pela $\mathrm{CRHi}$, em 2010, apontou que:

- Os representantes não representam suas instituições, mas sim seus posicionamentos individuais; e

- Os representantes de alguns setores do Estado são muito tímidos (EMPINOTTI, 2010). 


\subsubsection{Capacitação técnica em recursos hídricos}

Outro grande desafio apontado pela ANA (2009) a ser equacionado é "a capacitação e o fortalecimento das instituições integrantes do SINGREH, incluindo as entidades dos sistemas estaduais, a partir de seus membros" (p. 37).

A percepção do grupo de 17 representantes das instâncias do SIGRH, levantada durante pesquisa realizada em 1995, apontou para a necessidade de desenvolvimento de capacitação técnica dos quadros do Estado, dos Municípios e da Sociedade Civil (SMA, 1995). "Não se consegue descentralizar nada sem, primeiro, passar por um processo de capacitação institucional" (SMA, 1995, p. 60). Ao falar da importância da implantação dos instrumentos de gestão e do papel dos governos federal, estadual e municipal para essa execução, FREITAS (2000) lembra que "a falta de preparo institucional e técnico dos órgãos públicos terminam, em alguns casos, por prejudicar a implantação de medidas conservacionistas sobre os recursos, bem mais que a própria percepção dos problemas ambientais pela sociedade" (p. 63).

Este pensamento é compartilhado por REBOUÇAS (1999), ao afirmar que:

"O País precisa valorizar sua capacitação técnica em recursos hídricos, saneamento e meio ambiente, representada pelos profissionais pertencentes a órgãos e entidades públicas, a universidades e centros de pesquisa e a empresas privadas de consultoria especializada - gravemente ameaçados pela crise política e econômica da última década - e promover a cooperação institucional" (p. 35).

Conforme já citado na Introdução deste trabalho, vários autores apontam a existência de deficiências na capacitação dos membros de comitês no Brasil. A capacitação de tais membros, por serem eles participantes das decisões relacionadas à gestão dos recursos hídricos, é condição 
indispensável ao bom funcionamento e à democratização do processo decisório (PORTO e PORTO, 2008; PEREIRA e JOHNSSON, 2005). "Para poder participar de forma efetiva é desejável e necessário conhecer conceitos, leis, organismos, estruturas e os instrumentos de gestão dos recursos hídricos" (MMA, 2009a, p. 25). Tal pensamento é compartilhado por OLIVI (2004) que, durante pesquisa realizada no Comitê Tietê Jacaré, constatou dificuldades na priorização de projetos para financiamento pelo FEHIDRO causadas, dentre outros fatores, pela capacitação inadequada dos membros da câmara técnica responsável por esta atividade. Ao afirmar que "há que se conhecer todos os instrumentos existentes para bem utilizá-los na tomada de decisões das questões financeiras e, consequentemente, ambientais" (p. 71), a autora ressalta a diferença entre capacitação técnica e formação profissional, "que cada um de seus membros muito bem possui" (p. 71).

SOUZA (2007) também defende a necessidade de capacitação dos representantes da sociedade no geral para ampliação de sua participação. Durante pesquisa junto aos representantes do conselho gestor da Área de Preservação Ambiental Capivari - Monos, no município de São Paulo, a autora constatou grande dificuldade dos conselheiros locais para acompanhar discussões técnicas, dificultando assim as relações sociais e a solução de conflitos.

Ao serem questionados sobre os desafios para a próxima década durante pesquisa realizada em 2010 junto a 33 representantes que atuam no SIGRH, foi ressaltada a preocupação com a formação de sucessores, devido à necessidade de muitos anos para compreensão do sistema, e apontada a percepção da "falta de conhecimento mais acentuada no segmento dos municípios onde muitas questões não foram respondidas por falta de conhecimento dos instrumentos" (EMPINOTTI, 2010, p. 115). 
Sabe-se que "vontade política e conhecimento técnico são elementos fundamentais para se viabilizar o sistema. Mas a visão política é limitada para entender como prioridade a gestão de recursos hídricos" (SMA, 1995, p. 63).

\subsubsection{Sensibilização, informação e comunicação}

Os autores PORTO e PORTO (2008) e MAGALHÃES JÚNIOR (2007), conforme já apontado no Capítulo 1, ressaltam que a existência de dados e informações sobre recursos hídricos é essencial ao bom funcionamento dos comitês, colegiados responsáveis por decisões significativas para a gestão integrada das bacias. "Sem informação, não há participação" (MMA, 2009a, p. 3). Tal pensamento é reforçado por FREITAS (2000) ao afirmar que o comitê de bacias hidrográficas "necessita de informações sobre o meio fornecidas pelos instrumentos de gestão ambiental" (p. 82).

"Sensibilização social para a promoção e o fortalecimento de atitudes e comportamentos alinhados à essência da Política - este é o primeiro passo para que cada vez mais pessoas e organizações estejam preparadas para participar da gestão das águas de sua região" (MMA, 2009a, p. 3). E sensibilização se faz por meio de informação, transparência e comunicação dos envolvidos.

A pesquisa conduzida em 1995 junto a 17 representantes do sistema apontou que:

- A circulação de informações ocorreu privilegiadamente no âmbito da representação estadual, sendo que representantes dos municípios desconheciam a lei;

- Ficou evidente o desnível de informação entre os segmentos participantes, gerando desconfianças e discordâncias no processo de aprovação de projeto; 
- Existem dificuldades para estabelecer fluxo de informações interno em algumas entidades estaduais e da sociedade civil;

- Há necessidade de um sistema de informações;

- Há desinformação e falta de consciência tanto nos governos municipais, inclusive dos prefeitos, quanto na sociedade civil; (SMA, 1995).

Passados 15 anos desta pesquisa, a situação levantada durante a Avaliação dos 20 anos do SIGRH, apesar das melhorias apresentadas, mostra que ainda há muito por fazer em relação à Comunicação interna e externa aos comitês.

O item Comunicação, Articulação e Integração externa ao sistema recebeu a pior nota desta avaliação e foi criticada por representantes dos três segmentos. As considerações finais da consultoria Empinotti Ambiental mostram que:

"Todos os segmentos concordam que a sociedade no geral não conhece o sistema de gestão estando mais exposta à problemática da água, mas não da sua gestão. Uma das principais consequências dessa falta de conhecimento é o impacto sobre a representação da sociedade civil que é preenchida por muito tempo pelos mesmos grupos. Esta situação está levando a uma crise de representação e ao enfraquecimento do sistema uma vez que os mesmos grupos se perpetuam nos colegiados estão, muitas vezes, interessados na possibilidade de ter acesso a recursos deixando em segundo plano o seu trabalho na melhoria do sistema e na representação dos interesses da sociedade civil com relação a questões dos recursos hídricos no estado" (EMPINOTTI, 2010, p. 68).

Apesar deste quadro, foram detectadas melhorias desde 2007, com a criação de ferramentas e disponibilização de informações, porém ainda não com a forma adequada para atingir a maior parte dos públicos de interesse. Até mesmo representantes do segmento dos municípios reconheceram que "o assunto é muito técnico e por isso afasta os prefeitos de participarem mais intensamente" (EMPINOTTI, 2010, p. 67). 
Apesar de melhor avaliada que a Comunicação externa, muitos problemas foram apontados na Comunicação, Articulação e Integração interna ao SIGRH, dentre os quais destacamos:

- A comunicação acontece mais por meio de relações pessoais que pelo sistema formal de troca de informações;

- Não há rotina de comunicação;

- As informações estão concentradas nas mãos dos representantes estaduais;

- As informações não chegam com a antecedência necessária para a preparação para as reuniões;

- A comunicação é mais intensa dentro dos comitês, mas é pequena entre colegiados;

- É importante a disponibilização e atualização de informações nos sites dos comitês, incluindo estudos técnicos e provimentos do FEHIDRO; e

- É difícil manter os membros atualizados devido às mudanças frequentes de participantes.

\subsubsection{Planos de Bacia}

No início da implantação dos comitês de bacia, MARIANO (1996) constata, ao entrevistar representantes do CONSEMA e do CBH PCJ, que, apesar de ser "charmoso" "dizer que está promovendo participação social" (p. 101), não há participação em alguns assuntos importantes, tais como planejamento. Afirma que "não se convida a planejar junto, a definir os pressupostos juntos e não se dá escolha à decisão" (p. 101).

Segundo NEDER (2000), para garantir um bom funcionamento dos comitês de bacias é necessário que os comitês tenham forte comunicação e articulação com as prefeituras para a construção de prioridades 
comuns. Apesar desta aproximação ter sido aprimorada ao longo dos anos, há uma forte divergência quando se trata dos planos de médio e longo prazo em função do baixo interesse dos executivos municipais em negociar matérias que ultrapassem o período do seu mandato.

A avaliação realizada pela consultoria Empinotti Ambiental apontou uma melhora nos Planos de Recursos Hídricos elaborados nos últimos vinte anos, motivada pela necessidade dos planos servirem de base para a liberação de recursos, não só do FEHIDRO, como também os provenientes da cobrança. $\mathrm{Na}$ opinião dos representantes do Estado, tal vinculação fomentou uma maior participação dos usuários e de organizações não governamentais na formulação dos planos de bacia. Dentre os problemas e sugestões apontados, destacam-se:

- O plano deve ser elaborado pelos membros dos comitês por meio de discussões e de câmaras técnicas responsáveis por esse trabalho, ou pelo Estado, mas não por consultorias;

- Várias entidades não têm conhecimento do plano; e

- A Secretaria de Planejamento do Estado não enxerga as UGRHIs como unidade de planejamento e não utiliza os planos como subsídio ao orçamento plurianual das secretarias estaduais (EMPINOTTI, 2010).

\subsubsection{Recursos financeiros - FEHIDRO e Cobrança}

A pesquisa qualitativa realizada junto aos representantes do sistema, em 1995, apresentou as seguintes considerações sobre a gestão dos recursos financeiros, dentre as quais destacam-se:

- Critérios para alocação dos recursos financeiros devem ser definidos pelos comitês de bacia que a controlam;

- É importante a participação dos 3 setores na gestão dos recursos financeiros; $e$ 
- Fator motivador para a participação dos municípios é a nova fonte de recursos financeiros (SMA, 1995).

Esta última consideração é também apontada por OLIVI (2004) em pesquisa sobre o $\mathrm{CBH} T \mathrm{TJ}$, onde constatou que a maioria dos representantes das prefeituras municipais só participa das atividades do comitê visando obter "verbas para a realização de obras, as quais se revestem de propaganda eleitoral para o governo executivo local, e não necessariamente influenciam na política ambiental local" (p. 93).

Em 2010, a Avaliação dos 20 anos do Sistema elaborado pela consultoria Empinotti Ambiental constatou que alguns comitês trabalham muito bem, mas há outros que só se reúnem para discutir recursos (EMPINOTTI, 2010).

Quanto à cobrança, sua criação foi vista como uma mostra do amadurecimento do sistema e o processo participativo de definição dos valores da cobrança foi apontado como fomento à negociação e à participação dos atores do sistema e responsável pela baixa inadimplência no pagamento pelos seus usuários (EMPINOTTI, 2010). A consulta prévia aos segmentos dos usuários, potenciais pagadores, e à comunidade em geral sobre os critérios e valores da cobrança "garantiu a confiança e a credibilidade ao sistema, ferramentas básicas para a baixa inadimplência" (ANA, 2009, p. 170). É importante citar a avaliação feita por MACHADO (2009):

"A grande negociação ocorrida nas Bacias dos PCJ, para a construção de mecanismos e valores de cobrança pelo uso da água, representou um rico processo pedagógico, implicando em conhecimento acumulado com informações para outras regiões do país que também estão transitando rumo à implantação do sistema integrado de gestão de recursos hídricos" (p. 15).

Esse instrumento foi considerado fator de mudança de comportamento, cuja função principal é a conscientização da importância da água e do seu 
uso racional. Vários aspectos foram apontados pelos representantes dos três segmentos para que este instrumento atinja seus objetivos, dentre os quais destacamos:

- A cobrança deve ser pensada em cada bacia, e não ser obrigatória para todas; e

- O plano de implantação da cobrança está atrasado, pois o processo de definição de valores, por ser democrático e novo, é muito lento e o Estado não tem rapidez para auxiliar os comitês (EMPINOTTI, 2010).

\subsubsection{Aspectos gerais}

Segundo ARCE (2003), no Estado de São Paulo havia cerca de três mil pessoas engajadas no SIGRH no ano de 2003, participando de atividades do $\mathrm{CRH}$ ou dos 21 comitês, ou ainda nas diversas câmaras técnicas destes colegiados. Tais representantes dedicavam, com maior ou menor intensidade ou preparo, uma parcela de seu tempo às atividades de gestão de recursos hídricos.

Sabe-se que atualmente este número de pessoas já aumentou, aumento este provocado pela complexidade maior dos problemas de cada região e consequente criação de novas câmaras e grupos de trabalho. Porém, apesar do grande número de profissionais envolvidos e do alto montante de recursos financeiros utilizados, decorridos 14 anos da promulgação da Lei Federal № 9433/97 e 19 anos da Lei Estadual o 7663/91, é necessária uma otimização deste sistema. Visando alcançar resultados em espaço de tempo mais curto, os desafios apresentados neste item, dentre outros, precisam ser vencidos. 


\section{CATEGORIAS PARA A ANÁLISE DO PROCESSO PARTICIPATIVO NA GESTÃO DE RECURSOS HÍDRICOS}

No Capítulo 4 foram apresentados aspectos conceituais da gestão de recursos hídricos, com ênfase no processo participativo, recomendações resultantes dos principais fóruns globais sobre água e meio ambiente e experiências de três países na gestão das águas. Uma lista de 10 lições foi apresentada no item 4.5 como extrato dos principais aspectos apresentados.

O Capítulo 5 tratou da gestão dos recursos hídricos no Brasil, relatando fatos importantes da história da administração das águas no país e sua evolução para o sistema de gerenciamento de recursos hídricos em vigência atualmente, regidos pelas Políticas Nacional e Estaduais de Recursos Hídricos, instituídas na década de 1990. Finaliza, no item 5.6, com desafios a serem vencidos pelo atual sistema.

Ao traçar um paralelo entre esses dois capítulos, é possível avaliar o quanto o país aprendeu dessas lições, o quanto a gestão de recursos hídricos avançou no Brasil, como também avaliar o quanto ainda é necessário avançar.

Cabe citar MACHADO (2009):

"Um dos maiores méritos do sistema integrado de gestão de recursos hídricos é a descentralização, permitindo a plena participação da sociedade e dos usuários na formulação de planos para as bacias hidrográficas. A descentralização da gestão, que consolida o processo de democratização das decisões, considera a realidade de um país com dimensões continentais e com enorme pluralidade de situações entre suas bacias hidrográficas.

Neste cenário, o funcionamento dos Comitês de Bacias Hidrográficas, como verdadeiros Parlamentos das Águas, é a garantia da participação ativa das respectivas bacias na indicação dos programas, projetos e obras direcionados a recuperar e proteger os recursos hídricos" (p. 14). 
Esta pesquisa tem como objetivo geral analisar o processo de participação em comitês de bacias hidrográficas do Estado de São Paulo e suas implicações na implementação de instrumentos de gestão. Para isso, como apontado pelo $1^{\circ}$ objetivo específico apresentado no Capítulo 2, a proposta é concentrar esta análise nos aspectos relacionados à participação no processo de implementação dos instrumentos de gestão.

Portanto, das 10 lições apresentadas no item 4.5, o estudo de caso realizado no Comitê da Bacia Hidrográfica do Tietê - Jacaré se fixou nos temas relacionados às lições 5 a 10, como descrito a seguir. Conforme metodologia descrita no Capítulo 3, além da pesquisa feita nos documentos do CBH TJ, o estudo de caso também levantou a opinião dos principais atores na bacia escolhida através de entrevistas. Nestas entrevistas, surgiram comentários relativos à lição 3 que, apesar de não ser objeto principal desta pesquisa, foi aqui incluída.

Lição 3. Adoção da bacia hidrográfica como unidade de gestão

Apesar do consenso existente sobre a conveniência da adoção da bacia hidrográfica como unidade de gestão, vários problemas têm surgido em nosso país em relação às diferenças entre limites administrativos e limites de bacia, conforme citados no item 5.6.1. Este assunto, apesar de não estar ligado diretamente à participação pública, apareceu em respostas a outras questões durante as entrevistas realizadas junto aos membros do CBH TJ. Tais citações estão também apresentadas no Capítulo 7.

Lição 5. Participação pública no planejamento e na tomada de decisão englobando todos os envolvidos

Um dos princípios fundamentais para a gestão de recursos hídricos é a participação efetiva de todos os atores envolvidos no processo de 
planejamento e tomada de decisão. Esse princípio, pregado pela Constituição Federal de 1988 e adotado pelas Políticas Nacional e Estaduais de Recursos Hídricos vem sendo aplicado nos comitês de bacia. Porém, para seu pleno atendimento, alguns desafios precisam ser vencidos, conforme já apresentado nos itens 5.6 .2 a 5.6.6. Durante o estudo de caso no $\mathrm{CBH}$ TJ foram feitos levantamentos sobre a composição deste comitê, a rotatividade dos representantes e a frequência às plenárias. Nas entrevistas, foram tratados os seguintes aspectos:

- Participação dos envolvidos no planejamento e na tomada de decisão, quanto às condições de participação dos membros no comitê e à composição dos comitês;

- Representatividade da entidade participante no colegiado, nos aspectos relacionados a sua atuação no comitê e à abrangência de seu posicionamento, como representante de sua categoria ou apenas da própria entidade; e

- Representatividade do representante na entidade, abrangendo três aspectos: sua atuação na entidade, a atuação da entidade no $\mathrm{CBH}$, e a abrangência de seu posicionamento, como porta-voz da entidade ou apenas com seu posicionamento pessoal.

Lição 6. Capacitação dos profissionais envolvidos

Apesar de considerada como um dos pré-requisitos para o sucesso de um sistema de gestão de recursos hídricos, a capacitação técnica em recursos hídricos dos diversos profissionais envolvidos foi também apontada, no item 5.6.7, como um dos desafios atuais dos comitês existentes no país. Nas entrevistas aos membros do Comitê Tietê - Jacaré foram levantados dados sobre a instrução dos representantes do comitê e sobre os conhecimentos específicos na área de recursos hídricos. 
Lição 7. Sensibilização por meio de informação, transparência e comunicação dos envolvidos

Para se viabilizar a participação pública efetiva no processo de planejamento e tomada de decisão, é imprescindível que todos os atores envolvidos sejam sensibilizados sobre a importância de sua participação. Para isso, é necessário que tenham acesso à informação, pois "sem informação, não há participação" (MMA, 2009a, p. 3). Porém, ainda há obstáculos a serem vencidos em relação à comunicação nos comitês em geral, conforme apontado no item 5.6.8. No CBH Tietê - Jacaré, a informação e a comunicação aos envolvidos foram abordadas nas entrevistas analisando separadamente a comunicação interna e a comunicação externa ao comitê.

Lição 8. Estabelecimento de instrumentos de gestão

As Políticas Nacional e Estaduais de Recursos Hídricos estabelecem instrumentos de gestão para possibilitar sua implementação. Nesta pesquisa serão abordados apenas dois deles - plano de bacia e cobrança pelo uso dos recursos hídricos - conforme razões apresentadas no item 3.3.2, que serão avaliados em conjunto às próximas lições - 9 e 10.

Lição 9. Elaboração de planejamento integrado da bacia a curto, médio e longo prazos

Um dos instrumentos de gestão de recursos hídricos instituídos pela Lei Federal o 9433/97, o Plano de Bacia deve contemplar estratégias a curto, médio e longo prazos para cuidar das águas da bacia. Sua aprovação é atribuição do comitê da bacia. Foi constatada uma evolução desde a elaboração dos primeiros planos e apontados alguns pontos de melhoria para sua elaboração no item 5.6.9. O estudo de caso efetuado na bacia 
Tietê - Jacaré aborda a elaboração deste Plano no item 7.4 e foi levantada a opinião dos membros do $\mathrm{CBH}$ TJ quanto à satisfação no processo, como também quanto à participação no processo.

Lição 10. Equilíbrio orçamentário e autonomia financeira em cada bacia, seguindo os princípios utilizador - pagador e poluidor pagador

O instrumento de gestão instituído pelas Políticas Nacional e Estaduais de Recursos Hídricos que segue os princípios utilizador - pagador e poluidor - pagador é a cobrança pelo uso dos recursos hídricos. A formulação dos critérios para definição dos valores a serem cobrados dos diversos usuários é atribuição dos comitês de bacia. Tais colegiados também têm autonomia para definir sobre a aplicação dos recursos arrecadados. Alguns aspectos foram detectados no processo de implementação deste instrumento, conforme citados no item 5.6.10.

A pesquisa no $\mathrm{CBH} T \mathrm{TJ}$ abrange a participação dos atores no processo de formulação dos critérios do instrumento cobrança, apresentado no item 7.5, e foi levantada a opinião dos membros sobre dois aspectos: quanto à satisfação no processo e quanto à participação no processo.

Resultado final

Visando contribuir para a otimização do sistema atual de gestão de recursos hídricos, a satisfação dos membros do Comitê da Bacia Tietê Jacaré em relação à atual gestão de recursos hídricos foi avaliada no estudo de caso, considerando aspectos ligados à gestão local, da bacia TJ, e aspectos referentes à gestão regional, isto é, de todo o estado. 
Para levantar a opinião dos membros do CBH TJ sobre esses assuntos

listados, foi aplicado o questionário apresentado no quadro 1 , cujos resultados estão apresentados no item 7.6.

\section{Quadro 1: Questionário segundo Categorias de Análise}

\begin{tabular}{|c|c|c|}
\hline Categorias de Análise & $\begin{array}{l}\text { Aspecto a ser } \\
\text { analisado }\end{array}$ & Perguntas feitas nas entrevistas \\
\hline \multirow{4}{*}{$\begin{array}{l}\text { Participação dos } \\
\text { Envolvidos no } \\
\text { Planejamento e na } \\
\text { Tomada de Decisão }\end{array}$} & \multirow{3}{*}{$\begin{array}{c}\text { Condições de } \\
\text { Participação dos } \\
\text { Membros no Comitê }\end{array}$} & $\begin{array}{l}\text { 2.11 Você recebe alguma ajuda financeira para } \\
\text { comparecer às reuniões? Especificar quais: } \\
\text { transporte, alimentação, diária. }\end{array}$ \\
\hline & & $\begin{array}{l}2.12 \text { Você está satisfeito com suas condições de } \\
\text { participação no comitê? }\end{array}$ \\
\hline & & $\begin{array}{l}\text { 2.15 Você vê algum problema na participação de } \\
\text { algum segmento específico na gestão da bacia? } \\
\text { Citar o tipo de problema. }\end{array}$ \\
\hline & $\begin{array}{l}\text { Composição dos } \\
\text { Comitês }\end{array}$ & $\begin{array}{l}2.16 \text { Você vê algum problema na composição do } \\
\text { comitê, quanto ao número de vagas e/ou quanto } \\
\text { às entidades participantes? }\end{array}$ \\
\hline \multirow{4}{*}{$\begin{array}{l}\text { Representatividade da } \\
\text { Entidade }\end{array}$} & \multirow[t]{2}{*}{ Atuação no CBH } & $\begin{array}{c}2.2 \text { Há quanto tempo sua entidade está } \\
\text { representada neste comitê - na plenária e em } \\
\text { Câmaras Técnicas? }\end{array}$ \\
\hline & & $\begin{array}{c}2.14 \text { Você acha que a participação de sua entidade } \\
\text { é importante para a gestão da bacia? }\end{array}$ \\
\hline & \multirow{2}{*}{$\begin{array}{l}\text { Abrangência do } \\
\text { Posicionamento }\end{array}$} & $\begin{array}{c}2.9 \text { No caso de entidade que representa uma } \\
\text { categoria: Você costuma buscar a opinião e/ou as } \\
\text { necessidades das demais entidades do seu setor } \\
\text { para levar ao comitê? }\end{array}$ \\
\hline & & $\begin{array}{c}2.10 \text { No caso de entidade que representa uma } \\
\text { categoria: Você costuma divulgar as decisões do } \\
\text { comitê a essas entidades? } \\
\end{array}$ \\
\hline \multirow{8}{*}{$\begin{array}{l}\text { Representatividade do } \\
\text { Representante }\end{array}$} & Atuação na entidade & 1.4 Cargo do representante na entidade \\
\hline & \multirow{3}{*}{ Atuação no CBH } & 2.3 Há quanto tempo você participa do Comitê? \\
\hline & & $\begin{array}{l}\text { 2.4 Antes de atuar na plenária, você já atuou em } \\
\text { alguma Câmara Técnica? }\end{array}$ \\
\hline & & $\begin{array}{c}2.13 \text { Você acha que sua participação é importante } \\
\text { para a gestão da bacia? }\end{array}$ \\
\hline & \multirow{4}{*}{$\begin{array}{l}\text { Abrangência do } \\
\text { Posicionamento }\end{array}$} & $\begin{array}{l}\text { 2.5 Você recebe apoio técnico de outras pessoas } \\
\text { de sua entidade para sua atuação no comitê? }\end{array}$ \\
\hline & & $\begin{array}{l}\text { 2.6 Costuma compartilhar as idéias com outras } \\
\text { pessoas de sua entidade? }\end{array}$ \\
\hline & & $\begin{array}{l}\text { 2.7 Costuma buscar as opiniões dos colegas e/ou } \\
\text { superiores? }\end{array}$ \\
\hline & & $\begin{array}{c}2.8 \text { Costuma levantar as necessidades da entidade } \\
\text { para levar ao comitê? }\end{array}$ \\
\hline
\end{tabular}

continua 
Quadro 1: Questionário segundo Categorias de Análise

Continuação

\begin{tabular}{|c|c|c|}
\hline Categorias de Análise & $\begin{array}{l}\text { Aspecto a ser } \\
\text { analisado }\end{array}$ & Perguntas feitas nas entrevistas \\
\hline \multirow{5}{*}{$\begin{array}{l}\text { Capacitação Técnica } \\
\text { em Recursos Hídricos }\end{array}$} & \multirow{2}{*}{ Instrução } & 1.3 Profissão / Formação \\
\hline & & 1.11 Escolaridade \\
\hline & \multirow{3}{*}{$\begin{array}{l}\text { Conhecimentos } \\
\text { Específicos }\end{array}$} & $\begin{array}{c}\text { 3.1 Você conhece a Política Nacional de Recursos } \\
\text { Hídricos? }\end{array}$ \\
\hline & & 3.2 E a Política Estadual? \\
\hline & & $\begin{array}{l}\text { 3.3 Quais instrumentos de gestão dos recursos } \\
\text { hídricos você conhece? }\end{array}$ \\
\hline \multirow{4}{*}{$\begin{array}{l}\text { Informação e } \\
\text { Comunicação aos } \\
\text { Envolvidos }\end{array}$} & \multirow{3}{*}{$\begin{array}{c}\text { Comunicação Interna } \\
\text { ao } \mathrm{CBH}\end{array}$} & $\begin{array}{c}4.1 \text { Você recebe informações sobre o andamento } \\
\text { da implantação dos instrumentos de gestão na sua } \\
\text { bacia? }\end{array}$ \\
\hline & & $\begin{array}{l}\text { 4.2 Você conhece o Plano da Bacia do Tietê - } \\
\text { Jacaré? }\end{array}$ \\
\hline & & $\begin{array}{c}\text { 4.7 Você conhece os critérios definidos pelo } \\
\text { Comitê Tietê - Jacaré para a cobrança pelo uso } \\
\text { dos recursos hídricos? }\end{array}$ \\
\hline & $\begin{array}{c}\text { Comunicação Externa } \\
\text { ao } \mathrm{CBH}\end{array}$ & $\begin{array}{l}\text { 5.1 Você tem informações sobre o andamento das } \\
\text { atividades dos demais comitês do estado? }\end{array}$ \\
\hline \multirow{4}{*}{$\begin{array}{l}\text { Estabelecimento do } \\
\text { Plano da Bacia }\end{array}$} & $\begin{array}{c}\text { Satisfação no } \\
\text { Processo }\end{array}$ & $\begin{array}{l}4.3 \text { Você acha que este plano demonstra os } \\
\text { principais problemas e demandas da bacia? }\end{array}$ \\
\hline & \multirow{3}{*}{$\begin{array}{l}\text { Participação no } \\
\text { Processo }\end{array}$} & $\begin{array}{l}\text { 4.4 Sua entidade participou da elaboração desse } \\
\text { plano? }\end{array}$ \\
\hline & & $\begin{array}{l}\text { 4.5 As demais entidades do comitê participaram } \\
\text { da elaboração do plano? }\end{array}$ \\
\hline & & $\begin{array}{c}\text { 4.6 Você considera que a participação dos } \\
\text { diversos segmentos foi importante para a } \\
\text { qualidade do Plano de Bacia? }\end{array}$ \\
\hline \multirow{3}{*}{$\begin{array}{l}\text { Estabelecimento da } \\
\text { Cobrança pelo Uso da } \\
\text { Água }\end{array}$} & $\begin{array}{l}\text { Satisfação no } \\
\text { Processo }\end{array}$ & $\begin{array}{l}\text { 4.8 Sua entidade está satisfeita com os critérios } \\
\text { formulados? }\end{array}$ \\
\hline & \multirow{2}{*}{$\begin{array}{l}\text { Participação no } \\
\text { Processo }\end{array}$} & \begin{tabular}{|c|}
4.9 Você, ou outro representante de sua entidade, \\
participou do GT Cobrança?
\end{tabular} \\
\hline & & $\begin{array}{c}\text { 4.10 Você considera que a participação dos } \\
\text { diversos segmentos neste processo foi } \\
\text { significativa? }\end{array}$ \\
\hline \multirow{4}{*}{ Resultado Final } & \multirow{2}{*}{$\begin{array}{l}\text { Satisfação com a } \\
\text { Gestão Local }\end{array}$} & $\begin{array}{l}\text { 4.11 Você está satisfeito com a gestão atual dos } \\
\text { recursos hídricos desta bacia? Justifique sua } \\
\text { resposta. }\end{array}$ \\
\hline & & \begin{tabular}{|c|}
4.12 Sua entidade está satisfeita com a gestão \\
atual dos recursos hídricos desta bacia? Justifique \\
sua resposta.
\end{tabular} \\
\hline & \multirow[t]{2}{*}{$\begin{array}{l}\text { Satisfação com a } \\
\text { Gestão Regional }\end{array}$} & $\begin{array}{l}5.2 \text { Você está satisfeito com a gestão de recursos } \\
\text { hídricos no Estado? Justifique sua resposta. }\end{array}$ \\
\hline & & 5.3 E sua entidade? Justifique sua resposta. \\
\hline
\end{tabular}




\section{ESTUDO DE CASO DO COMITÊ DA BACIA TIETÊ - JACARÉ}

Este capítulo apresenta o estudo de caso realizado no Comitê da Bacia Hidrográfica do Tietê - Jacaré e está dividido em 7 itens. Primeiramente, no item 7.1, é feita uma descrição desta bacia hidrográfica e, no item 7.2, do órgão de gestão desta bacia - o Comitê da Bacia Hidrográfica do Tietê - Jacaré (CBH TJ). No item 7.3 são apresentados alguns aspectos da situação encontrada atualmente neste comitê, seguidos da descrição dos processos relacionados a dois instrumentos de gestão escolhidos para acompanhamento nesta pesquisa: o Plano de Bacia, no item 7.4, e a Cobrança pelo uso dos recursos hídricos, no item 7.5. As respostas ao Questionário sobre Gestão de Recursos Hídricos, apresentado no Anexo 11.5, obtidas por meio de entrevistas aos membros do CBH TJ, são apresentadas no item $7.6 \mathrm{e}$, por fim, é feita uma análise geral dos resultados obtidos neste estudo, apresentada no item 7.7 .

As informações apontadas nos itens 7.1 ao 7.5 deste capítulo foram elaboradas com base nas pesquisas documentais realizadas via internet, no site do Sistema Integrado de Gerenciamento dos Recursos Hídricos (SIGRH), em visitas à sede do $\mathrm{CBH}$ TJ, localizada no Escritório de Apoio do DAEE de Araraquara, como também através de levantamentos efetuados junto aos materiais fornecidos pela secretaria executiva deste comitê. Para maior detalhamento de alguns aspectos ou esclarecimento de dúvidas, foram utilizadas informações coletadas junto à mesa diretora e à equipe de apoio do $\mathrm{CBH} \mathrm{TJ}$, ou ainda junto aos membros deste comitê durante as entrevistas para aplicação do questionário.

Fazem parte do material consultado documentos específicos deste $\mathrm{CBH}$, tais como atas e listas de presença de reuniões plenárias, deliberações aprovadas, documentos relacionados à priorização de ações da Revisão 
do Plano de Bacia, revistas, artigos de jornais e relatórios oficiais, em especial:

- Relatório Técnico sobre a Elaboração da Revisão do Plano de Bacia da Unidade de Gerenciamento de Recursos Hídricos do Tietê - Jacaré (UGRHI 13) (CPTI, 2008);

- Relatório de Fundamentos para Cobrança pelo Uso dos Recursos Hídricos na Bacia do Tietê - Jacaré (CBH TJ, 2009a); e

- Relatório de Situação dos Recursos Hídricos na Bacia Hidrográfica Tietê - Jacaré - ano de 2009 (CBH TJ, 2009b).

Os dados apresentados no item 7.6 se baseiam, exclusivamente, nas respostas obtidas durante a aplicação do questionário aos membros da plenária do $\mathrm{CBH} \mathrm{TJ}$, conforme descrito no item 3.3. Para a análise apresentada no item 7.7 foram utilizados os dados levantados neste estudo de caso, tanto na pesquisa documental, quanto nas respostas aos questionários.

Também foram de grande importância os conhecimentos adquiridos pela pesquisadora ao participar de quatro reuniões do comitê, conforme descrito no item 3.3.6.

Ressalta-se que o objetivo deste estudo de caso é analisar o processo participativo na gestão dos recursos hídricos desta bacia hidrográfica, e não as condições dos recursos hídricos ali existentes.

\subsection{DESCRIÇÃO DA BACIA HIDROGRÁFICA DO TIETÊ - JACARÉ}

A Bacia Hidrográfica do Tietê - Jacaré - UGRHI 13 - faz parte da Bacia do rio Tietê, que pertence à Região Hidrográfica da Bacia do Paraná (SMA, 2009a). Está localizada no centro do Estado, engloba o trecho do rio Tietê entre as barragens de Barra Bonita e de lbitinga e os rios Jacaré- 
Guaçu e Jacaré-Pepira (ver figura 3) e ocupa uma área de drenagem de $11.749 \mathrm{~km}^{2}$ (TUNDISI et al, 2008). Os 34 municípios integrantes da bacia são: Agudos, Araraquara, Arealva, Areiópolis, Bariri, Barra Bonita, Bauru, Boa Esperança do Sul, Bocaina, Boracéia, Borebi, Brotas, Dois Córregos, Dourado, Gavião Peixoto, lacanga, Ibaté, Ibitinga, Igaraçu do Tietê, Itaju, Itapuí, Itirapina, Jaú, Lençóis Paulista, Macatuba, Mineiros do Tietê, Nova Europa, Pederneiras, Ribeirão Bonito, São Carlos, São Manuel, Tabatinga, Torrinha e Trabiju (SMA, 2008). Além desses, cujas sedes estão dentro da UGRHI, partes dos territórios de outros 3 municípios também se situam nesta bacia, a saber: Analândia, Matão e São Pedro (FREITAS, 2000; LOPES, 2003; SMA, 2009a).

Figura 3: Mapa da Bacia Hidrográfica do Tietê - Jacaré

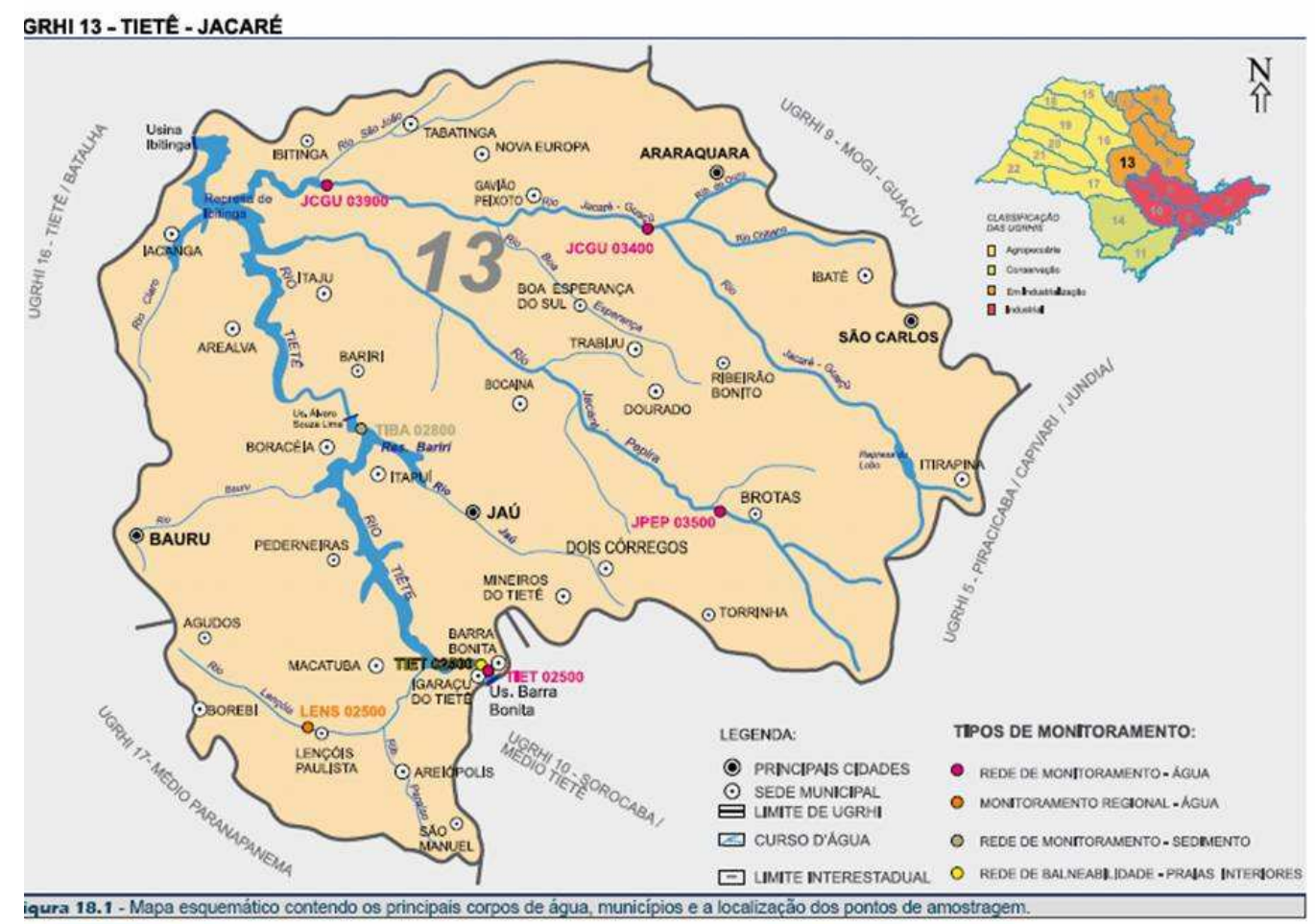

Fonte: Relatório de Qualidade das Águas Interiores no Estado de São Paulo (CETESB, 2006) 
A UGRHI 13 possui uma população de 1.478 .941 pessoas, segundo estimativa da Fundação Sistema Estadual de Análise de Dados (SEADE) de 2007 , sendo $96 \%$ concentrada em área urbana, e apresenta densidade demográfica média de $125,5 \mathrm{hab} / \mathrm{km}^{2}$. Os municípios desta bacia apresentam valores entre 0,7 e 0,8 para o Índice de Desenvolvimento Humano (IDH), o que corresponde a desenvolvimento humano médio (SMA, 2009a). Apenas 3,2\% da área desta bacia são ocupados pela urbanização, enquanto os $96,8 \%$ restantes se dividem pelos outros usos (CPTI, 2008).

Nesta bacia predominam atividades econômicas voltadas ao agronegócio, e na zona rural predominam extensas culturas de cana-de-açúcar e laranja, além de pastagens e áreas de reflorestamento. Na classificação quanto aos usos predominantes, esta UGRHI se caracteriza como em processo de industrialização (SMA, 2004) e as principais atividades industriais nela desenvolvidas são as indústrias alimentícias, em especial de bebidas, e as usinas de açúcar e álcool. O desenvolvimento econômico da região se deve também às indústrias de calçados de Jaú, de máquinas e equipamentos e ao polo tecnológico da região de São Carlos (SMA, 2009a), ao comércio de bordados em lbitinga e ao turismo em Barra Bonita e em Igaraçu do Tietê (CPTI, 2008).

A cobertura vegetal natural remanescente é composta de fragmentos da Mata Atlântica e do Cerrado, e cobre 4,8\% da área da UGRHI (SMA, 2009a). As maiores áreas de vegetação remanescente nesta bacia são encontradas nos municípios de Agudos, Brotas e São Carlos (CPTI, 2008). Convém salientar que esta UGRHI "é a que possui a maior área registrada de mata ciliar. Todo ano projetos de recuperação, conservação e proteção da vegetação recebem recursos FEHIDRO" (CBH TJ, 2009b, Anexo 2). 
O clima desta bacia é quente e úmido, com inverno seco. Quanto ao índice pluviométrico nesta UGRHI, os valores variam de cerca de $1200 \mathrm{~mm} / \mathrm{ano}$, registrados a leste de Bauru, nas vizinhanças de Pederneiras, a 1600 mm/ano, apresentado na região de São Carlos (CBH TJ, 2009a).

Nesta bacia, "a disponibilidade hídrica já é considerada crítica" (SMA, 2004, p. 19), uma vez que o volume de demanda global de água na bacia supera $50 \%$ da somatória da vazão mínima das águas superficiais e da disponibilidade total das águas subterrâneas. Ao avaliar a demanda total de recursos hídricos em termos de população equivalente, chega-se a quase 15 milhões de habitantes, correspondendo assim a uma população dez vezes maior que a encontrada na bacia. Isso acontece em função dos grandes volumes de água usados, em especial, para irrigação e uso industrial (SMA, 2009a). Nesta UGRHI, os recursos hídricos subterrâneos provêm dos aquíferos Bauru, Cenozoico, Guarani e Serra Geral (CPTI, 2008) e representam aproximadamente $70 \%$ das águas de abastecimento público (REZENDE, 2010). Apenas 3 municípios utilizam exclusivamente águas superficiais, 15 utilizam águas superficiais e subterrâneas e os 16 restantes se abastecem exclusivamente por captações subterrâneas. $O$ consumo de águas subterrâneas também é grande para consumo industrial, sendo que o total de poços cadastrados supera o de captações superficiais (FREITAS, 2000). Em 2007, havia 677 pontos de captação de águas superficiais e 1682 poços cadastrados no DAEE (CBH TJ, 2009a). É importante lembrar que "as águas subterrâneas são muito significativas tanto na captação para as diversas finalidades de uso quanto em termos de reserva" (CPTI, 2008, p. 14).

Além do trecho do rio Tietê entre as barragens de Barra Bonita e de Ibitinga, os principais corpos d'água da UGRHI 13 são o rio Jacaré-Guaçu, que nasce no município de Itirapina, logo abaixo da barragem da Represa do Lobo, e o rio Jacaré-Pepira, que nasce na divisa dos municípios de 
Brotas e São Pedro, na Serra de Itaqueri, e, após percorrer $174 \mathrm{~km}$, desemboca no Rio Tietê, no município de Ibitinga. Além destes, há também os rios Lençóis, Bauru, Jaú e Claro; os ribeirões Pederneiras, do Veado e Bonito; e as represas de Bariri, Ibitinga e do Lobo, ou do Broa, localizada no município de Itirapina (LOPES, 2003; SMA, 2009a).

O principal problema desta bacia é a poluição de seus rios devido à ausência de tratamento adequado dos resíduos sólidos e dos esgotos domésticos e industriais (TUNDISI et al, 2008). Apesar de apresentar índices satisfatórios de coleta de esgotos nos diversos municípios, com uma média na bacia de $94 \%$ dos esgotos coletados, os índices de tratamento de esgotos não acompanham esse patamar: apenas 35\% em relação aos esgotos coletados e $32,9 \%$ em relação aos esgotos gerados (SMA, 2009a). No relatório da revisão do Plano de Bacia foi apontada a necessidade de investimentos no tratamento dos esgotos domésticos de Bauru, São Carlos e Lençóis Paulista (CPTI, 2008). Atualmente, destes três, somente Bauru continua sem tratamento de esgotos instalado. Os índices apresentados por um dos rios mais fortemente afetados, o rio Lençóis, demonstraram comprometimento da qualidade da água justamente no ponto de captação do município de Lençóis Paulista (SMA, 2009a).

Atualmente o problema da poluição ainda não atingiu o rio Jacaré-Pepira, curso d'água de grande porte com grande importância para o turismo ecológico da região (TUNDISI et al, 2008). Porém, é importante apontar a baixa densidade da rede de monitoramento: há apenas 5 pontos de monitoramento de qualidade das águas superficiais da CETESB nesta bacia (SMA, 2009a), além de 1 ponto pertencente à Rede de Sedimento e um ponto da Rede de Balneabilidade de Rios e Lagos (CPTI, 2008). 
Quanto a resíduos sólidos, o Inventário Estadual de Resíduos Sólidos Domiciliares, elaborado pela Companhia de Tecnologia de Saneamento Ambiental (CETESB) em 2007, aponta que 20 municípios da bacia, isto é, $59 \%$ dos municípios destinavam seus resíduos de maneira adequada, equivalendo a apenas $55,6 \%$ dos resíduos da bacia TJ destinados a aterros classificados como adequados (SMA, 2009a). Essa situação, porém, demonstra uma significativa melhoria em relação ao final da década de 1990. LOPES (2003) mostra que, em 1997, "apenas $6 \%$ dos municípios depositavam seus resíduos em condições adequadas" (p. 90) e, 2 anos após, "esse índice atingiu 40\% dos municípios" (p. 90).

Outro problema encontrado nesta bacia é a ocorrência de processos erosivos que, em função do uso e ocupação do solo, poderá ser agravada mesmo em terrenos com média suscetibilidade à erosão. As principais causas da erosão em área urbana são a concentração de águas pluviais e a falta ou a ineficiência de sistemas de drenagem; e em áreas rurais são a retirada da mata ciliar e o manejo inadequado das terras para agricultura. Conforme o Relatório de Qualidade Ambiental do Estado de São Paulo de 2007, da SMA, apresentado na Revisão do Plano de Bacia, 5 municípios apresentam alta suscetibilidade à erosão. São eles: Agudos, Bauru, Ibitinga, Itaju e São Manuel (CPTI, 2008).

TUNDISI (2003) aponta que "no final da década de 1950, foram construídas grandes represas para produção de hidroeletricidade no Estado de São Paulo que, além da produção de energia, visavam também outros usos" (p. 92). No rio Tietê foram implantadas seis represas - Barra Bonita, Bariri, Ibitinga, Promissão, Nova Avanhandava e Três Irmãos -, sendo que as três primeiras estão situadas na bacia do Tietê - Jacaré, que "garantiram $700 \mathrm{~km}$ de hidrovia, além de serem locais voltados para recreação, pesca e turismo" (p. 93). No município de Pederneiras há um terminal intermodal facilitando a utilização da hidrovia Tietê - Paraná, que cobre atualmente $1000 \mathrm{~km}$, para o escoamento da produção do seu distrito 
industrial e dos municípios localizados no seu entorno, em especial para o transporte de cana de açúcar, material de construção e calcário, farelo, soja, grãos, madeira e fertilizantes (CBH TJ, 2009a; CPTI, 2008).

O rio Tietê é apontado também por BRUNA (1999) como um rio com grande possibilidade de alavancar planos e projetos para um desenvolvimento unindo turismo, comércio e agronegócio. A autora ressalta a importância da hidrovia para o transbordo da produção de São Paulo e estados vizinhos, e aponta seu potencial turístico, em especial na região situada nesta bacia. As águas do rio Tietê voltam a ficar limpas no município de Barra Bonita, pois no percurso entre a Região Metropolitana de São Paulo e Barra Bonita dá-se a autodepuração da poluição produzida pelos esgotos industriais e domésticos metropolitanos. Isso possibilita a prática de pesca e de esportes aquáticos em suas praias fluviais, como a Prainha de Igaraçu do Tietê, e também a realização de passeios turísticos na eclusa de Barra Bonita.

REZENDE (2010) ressalta a importância da cidade de Brotas, considerada capital do turismo de aventura no estado, em especial para a prática de esportes de aventura aquáticos nas corredeiras e cachoeiras do bem preservado Rio Jacaré-Pepira. Também aponta dois outros atrativos turísticos da bacia situados nas áreas alagadas na várzea do Rio Jacaré-Pepira, conhecido pela população local como "Pantaninho", e do Rio Jacaré-Guaçu, conhecido como "Varjão". Essas áreas formam um ecossistema com características semelhantes às do pantanal do Mato Grosso e estão localizadas no município de Ibitinga.

BRUNA (1999) afirma que "o aproveitamento da água doce para fins turísticos (...) tem certamente uma preciosa contribuição a dar, tanto em termos de poder atuar como um polo maior de atração como pela possibilidade de complementar a gama de atividades oferecidas e 
aumentar assim a vitalidade turística da área" (p. 665). Além de representar uma significativa fonte de receita no total do produto interno bruto nacional, a autora ressalta a importância da valorização do patrimônio ambiental, "à medida que sua história se transmite entre gerações e entre diferentes povos" (p. 665).

Outra fonte de receita nesta bacia, também proveniente de atividades que dependem da qualidade dos recursos hídricos, é a aquicultura, com predomínio da piscicultura e alguns pontos de ranicultura (FREITAS, 2000).

Também como uso não consuntivo dos recursos hídricos, além das 3 grandes represas ao longo do rio Tietê citadas anteriormente, há 18 barramentos de menor porte, também criados para fins de aproveitamento hidroelétrico, nos rios Jacaré-Guaçu, Monjolinho, Claro, Bauru, JacaréPepira, Lençóis e outros ribeirões desta UGRHI (FREITAS, 2000).

\subsection{DESCRIÇÃO DO COMITÊ DA BACIA HIDROGRÁFICA DO TIETÊ - JACARÉ}

Em cada UGRHI devem funcionar duas instituições para a gestão local de recursos hídricos: o Comitê da Bacia e a Agência da Bacia. Com estrutura administrativa e jurídica própria, esta última deve, além de exercer as funções de secretaria executiva do Comitê, "elaborar o plano de bacia hidrográfica, os relatórios anuais de situação dos recursos hídricos e gerenciar os recursos obtidos com a cobrança pelo uso da água" (SMA, 2004, p. 60). Segundo a Lei Estadual no 7663/91, "sua criação, por decisão do Comitê de Bacia Hidrográfica e aprovação do $\mathrm{CRH}$, ficou vinculada ao início da cobrança do uso da água" (SMA, 2004, p. 60). Na bacia em estudo ainda não há agência instalada e sua implantação consta como 9 ${ }^{a}$ prioridade do plano desta bacia (CBH TJ, 2009b). 
O Comitê da Bacia Hidrográfica do Tietê - Jacaré (CBH TJ) é o órgão responsável pelo gerenciamento da UGRHI 13 (FREITAS, 2000). Instalado em 10 de novembro de 1995, sua Secretaria Executiva tem sede no escritório regional do DAEE em Araraquara e conta com 36 representantes, sendo 12 de cada segmento (SMA, 2008), com direito a voz e voto (CBH TJ, 1999).

No segmento dos Municípios, os representantes titulares e suplentes deste comitê "devem ser exclusivamente os prefeitos, não sendo permitida a delegação dessa representação para outra pessoa, como acontece em alguns Comitês" (FREITAS, 2000, p. 91), nem mesmo para a participação esporádica em uma plenária. Durante pesquisa neste comitê, FREITAS (2000) coletou depoimentos de representantes que consideram ser essa decisão "um entrave para que a participação dos municípios possa acontecer de forma mais efetiva" (p. 91) e pensam que "os municípios deveriam ter um representante no Comitê que não necessariamente fossem os Prefeitos, como acontece nos setores estaduais" (p. 91).

É importante lembrar, como já citado no item 5.5.3.b, que vários municípios contêm área em duas ou mais bacias, sendo então necessário acompanhar as definições de mais de um comitê. Dos 34 municípios integrantes oficialmente neste $\mathrm{CBH}$ TJ, apenas 17 têm todo o seu território nesta UGRHI. Os demais municípios contêm parte de seu território em outras bacias, a saber: Agudos (UGRHIs 16 e 17), Araraquara (UGRHI 9), Barra Bonita (UGRHI 10), Bauru (UGRHI 16), Borebi (UGRHI 17), Dois Córregos (UGRHIs 5 e 10), lacanga (UGRHI 16), Ibaté (UGRHI 9), Ibitinga (UGRHI 16), Igaraçu do Tietê (UGRHI 10), Itirapina (UGRHI 5), Lençóis Paulista (UGRHI 17), Mineiros do Tietê (UGRHIs 5 e 10), São Carlos (UGRHI 9), São Manuel (UGRHIs 10 e 17), Tabatinga (UGRHI 16) e Torrinha (UGRHI 5) (FREITAS, 2000). 
Como há apenas 12 vagas para o segmento Municípios e 34 cidades situadas na bacia TJ, a escolha dos prefeitos para ocupar as 12 vagas de titulares e as 12 suplências é realizada através de eleição entre eles na data da posse do comitê a cada gestão, cuja duração é de 2 anos.

O segmento Estado é composto por 12 representantes de secretarias estaduais ou instituições ligadas a recursos hídricos e meio ambiente "que, prioritariamente, exerçam suas funções em unidades regionais existentes na UGRHI TJ" (CBH TJ, 1999, art. 7). Geralmente representantes da mesma instituição ocupam as vagas de titular e de suplente sendo que, nos casos em que há regionais diferentes de uma mesma instituição na bacia, essa representação é, prioritariamente, compartilhada pelas duas regionais (FREITAS, 2000). Os membros do Estado são designados formalmente pelos titulares das entidades representadas (CBH TJ, 1999).

A composição do segmento Sociedade Civil é a que mais diverge entre os comitês do estado, pois, para tal composição, deve ser considerada a especificidade regional. Esta composição, como definida pelo estatuto do CBH TJ, é feita por 12 representantes titulares e 12 suplentes, seguindo as "categorias abaixo relacionadas:

a) 1 (um) representante dos Usuários urbanos de águas;

b) 1 (um) representante dos Usuários rurais de águas;

c) 1 (um) representante dos Usuários industriais de águas;

d) 3 (três) representantes das Universidades;

e) 1 (um) representante dos Institutos de Pesquisas;

f) 1 (um) representante das Entidades Ambientalistas;

g) 1 (um) representante das Entidades de Recuperação Florestal;

h) 1 (um) representante das Associações de Classes e Sindicatos;

i) 1 (um) representante das Associações Técnicas;

j) 1(um) representante das Associações de Esportes, Turismo, Lazer e Navegação" (CBH TJ, 1999, art. 7). 
$\mathrm{Na}$ relação deste comitê, merece destaque o setor das Universidades, com direito a três vagas, ocupadas pelas três universidades instaladas na região, a saber, Universidade de São Paulo (USP), Universidade Federal de São Carlos (UFSCar) e Universidade Estadual Paulista (UNESP) (SÃO PAULO, 2003). Além destas, há participação ativa de outra instituição de nível superior na vaga de Institutos de Pesquisas desde a gestão 1999 2001.

A participação no segmento Sociedade Civil é feita por meio de inscrição das entidades interessadas e, no caso do número de inscritos ultrapassar o total das vagas disponíveis na categoria, a escolha é feita pelos pares em reunião plenária.

É importante observar que, nos segmentos Estado e Sociedade Civil, "o membro que deixar o órgão ou a entidade a qual representa, será substituído por outro membro indicado, sem prejuízo para o órgão ou entidade representada" (CBH TJ, 1999, art. 7), porém tal tratamento é diferente no segmento Municípios, no qual "os mandatos dos prefeitos (...) coincidirão com os mandatos municipais” (CBH TJ, 1999, art. 7).

De acordo com seu estatuto, "o CBH TJ será presidido por um dos seus membros, eleito por seus pares, com mandato de dois anos, cabendo uma reeleição" (CBH TJ, 1999, art. 8). Também deve ser eleito por seus pares um Vice-Presidente "com mandato coincidente ao da Presidência, cabendo uma reeleição" (CBH TJ, 1999, art. 11). A Secretaria Executiva deverá ser "coordenada por um Secretário Executivo, eleito pelo CBH TJ, com mandato de dois anos" (CBH TJ, 1999, art. 12) e não há restrição à reeleição deste cargo pelo seu estatuto. Cabe ressaltar que cada cargo deverá ser ocupado por um dos três segmentos que compõem o comitê.

$\mathrm{O}$ artigo 16 do estatuto estabelece que as funções de membros deste comitê não serão remuneradas (CBH TJ, 1999). 
As convocações para reuniões plenárias são feitas por ofícios enviados pelo correio, com aviso de recebimento. Visando uma análise prévia dos assuntos a serem discutidos nas reuniões plenárias, segundo relato do secretário executivo, os membros recebem pelo correio, junto às convocações das reuniões, todo o material relacionado à pauta. São feitas no mínimo 2 reuniões plenárias ordinárias em cada ano, sendo uma por semestre, nas quais as decisões são "tomadas por aclamação ou, em sua impossibilidade, por maioria simples dos presentes" (CBH TJ, 1999, art. 27).

Alguns assuntos, antes de serem levados para aprovação do plenário, são discutidos em reuniões conjuntas das câmaras técnicas, após a discussão na câmara técnica relacionada diretamente ao assunto em questão. Atualmente encontram-se atuantes neste comitê 5 Câmaras Técnicas: de Planejamento e Gestão, de Águas Subterrâneas, de Recursos Naturais, de Saneamento e de Educação Ambiental (CPTI, 2008), e também o Grupo de Trabalho de Cobrança.

\subsection{SITUAÇÃO ATUAL DO COMITÊ DA BACIA HIDROGRÁFICA DO TIETÊ - JACARÉ}

Conforme apresentado no relatório Situação dos Recursos Hídricos no Estado de São Paulo - Ano base 2007, elaborado pela SMA (2009a), a implantação dos instrumentos de gestão de recursos hídricos neste comitê apresentava a seguinte situação:

- Os instrumentos Relatório de Situação dos Recursos Hídricos e Plano de Recursos Hídricos da Bacia encontravam-se implementados;

- Os instrumentos Cobrança pelo Uso dos Recursos Hídricos e Cadastro de Cobrança encontravam-se em implementação; 
- O Enquadramento dos Corpos d'Água encontrava-se "em conformidade com o Decreto Estadual 10755/77, porém há necessidade de atualização" (p. 48); e

- O Sistema de Informação sobre Recursos Hídricos apresentava dificuldades para sua implementação.

Desde então, aconteceram avanços significativos em relação ao instrumento Cobrança que estão relatados no item 7.5.

Quanto à sua participação no Fundo Estadual de Recursos Hídricos (FEHIDRO), este comitê tem recebido recursos anualmente que, de 1997 a 2009 , somam $R \$ 19,68$ milhões, dos quais cerca de $40 \%$ foram aplicados em coleta e tratamento de esgotos. Neste período foram recebidos 302 projetos, dos quais 184 foram aprovados para financiamento (CBH TJ, 2009a).

Conforme explicação do vice-presidente e complementação por membros entrevistados, para a hierarquização de projetos a serem contemplados com recursos do FEHIDRO, cabe a cada câmara técnica do CBH TJ a análise dos projetos inscritos relacionados ao seu assunto. Para esta análise, devem ser atendidas as regras estipuladas pelo comitê e as prioridades definidas em seu plano de bacia. Tais regras foram modificadas no final de 2009, por meio da Deliberação CBH-TJ n. 0 07/09 de 17/12/2009. A hierarquização final é feita pela CT Planejamento e Gestão, em conjunto com os coordenadores das câmaras técnicas envolvidas, e é encaminhada para análise e aprovação pelos membros do comitê em reunião plenária.

Outra atividade sob responsabilidade dos comitês paulistas atualmente é a análise dos Estudos de Impacto Ambiental e dos Relatórios de Impacto Ambiental (EIA/RIMA) de empreendimentos a serem implantados nas respectivas bacias e encaminhamento de pareceres à SMA. Cabe às câmaras técnicas a avaliação e discussão de tais estudos e a elaboração 
dos pareceres, para encaminhamento e aprovação nas plenárias dos comitês. No comitê $T J$, tal análise é feita, geralmente, em reunião conjunta da CT Planejamento e Gestão com a câmara técnica com maior ligação ao empreendimento.

Em 25/03/2011, uma nova gestão se iniciou no CBH TJ: a gestão 2011 2013. Uma novidade nesta gestão foi a criação do cargo de secretário executivo adjunto para auxiliar os trabalhos da secretaria executiva. As alterações de representação em relação à gestão 2009 - 2011 são:

- Para a mesa diretora, foram eleitos membros que já faziam parte deste comitê para os cargos de presidente e secretário executivo, o vice-presidente se manteve e foi escolhido um membro antigo, do segmento Estado, para o novo cargo de secretário executivo adjunto;

- No segmento Estado houve troca de representação entre DAEE e Secretaria de Saneamento e Recursos Hídricos, antes Secretaria de Energia e Saneamento; e entraram pessoas novas para 2 suplências;

- No segmento Municípios, 6 prefeituras deixaram o comitê; 6 entraram como novos membros; e houve trocas entre titulares e suplentes; e

- Todos os titulares do segmento Sociedade Civil se mantiveram, e houve alteração de entidades em 2 suplências e de representantes de 3 entidades suplentes.

A renovação dos membros do comitê para o período de gestão 2009 2011, em relação à gestão 2007 - 2009, havia sido maior. As alterações observadas foram:

- Para a mesa diretora foram eleitos novos membros para os cargos de presidente e vice-presidente, e se manteve o ocupante do cargo de secretário executivo;

- No segmento Estado, houve apenas troca do nome de uma entidade, e permaneceram 9 titulares, 10 suplentes e um suplente que atuava como titular; 
- No segmento Municípios, 6 saíram e 6 entraram, além de algumas trocas de titularidade; quanto aos membros, 11 se mantiveram e entraram prefeitos novos em municípios que já faziam parte; e

- $\mathrm{Na}$ Sociedade Civil, 9 entidades titulares e 5 suplentes se mantiveram, houve trocas de titularidade e de cidade de uma entidade; dentre os representantes, 7 titulares e 2 suplentes permaneceram e houve troca entre titulares e suplentes.

\subsection{PROCESSO DE ESTABELECIMENTO DO PLANO DE BACIA}

A Revisão do Plano de Bacia da Unidade de Gerenciamento de Recursos Hídricos do Tietê - Jacaré (UGRHI 13) foi elaborada pela Cooperativa de Serviços e Pesquisas Tecnológicas e Industriais (CPTI). Contou com a participação de técnicos do Laboratório de Recursos Hídricos e Avaliação Geoambiental (LABGEO) do Centro de Tecnologias Ambientais e Energéticas (CETAE) do Instituto de Pesquisas Tecnológicas do Estado de São Paulo (IPT), da Fundação de Apoio Institucional para o Desenvolvimento Científico e Tecnológico (FAI) da Universidade Federal de São Carlos (UFSCar), da Fundação para o Incremento da Pesquisa e do Aperfeiçoamento Industrial (FIPAI) da Universidade de São Paulo (USP), da Fundação de Apoio à Ciência, Tecnologia e Educação (FACTE) da Universidade Estadual Paulista (UNESP) e do Centro Universitário de Araraquara (UNIARA) (CPTI, 2008).

Este trabalho teve como finalidade a atualização de dados e informações e a revisão do planejamento, conforme definidos pela Deliberação no 62 / 2006 do $\mathrm{CRH}$. Os resultados deste trabalho, objeto do contrato 087/2007, celebrado com a Nossa Caixa e financiado pelo Fundo Estadual de Recursos Hídricos (FEHIDRO), foram apresentados parcialmente no Relatório Técnico - no 402/08, em dezembro de 2008. 
Para atender os objetivos do Plano de Bacia, segundo seu Relatório Técnico, estabeleceu-se que sua elaboração deveria contar com a participação dos diversos setores envolvidos com o tema - integrantes do $\mathrm{CBH}$ e técnicos de órgãos do governo, entidades e instituições locais - e definiu-se que tal participação aconteceria via câmaras técnicas (CPTI, 2008). Uma das formas escolhidas para propiciar ampla participação foi a realização de audiências públicas. Foram realizadas 6 audiências públicas, sob a coordenação da UFSCar. A primeira delas aconteceu na cidade de São Carlos, em 14/09/2006, e as demais foram realizadas em Ibitinga, Jaú, Araraquara, Bauru e Brotas.

Seguindo proposta apresentada no Plano Estadual de Recursos Hídricos 2004/2007, "as Metas foram propostas e organizadas considerando-se três níveis ou componentes" (p. 7), a saber: Metas Estratégicas da Gestão de Recursos Hídricos; Metas Gerais; e Metas Específicas (CPTI, 2008). Em 2008, foram realizadas uma reunião de acompanhamento e uma oficina de trabalho envolvendo as equipes contratadas e membros da plenária e das câmaras técnicas do CBH TJ. Conforme descrição feita pelo secretário executivo e complementada por membros entrevistados, durante o ano de 2009 foi realizada a priorização das metas finais deste Plano. Inicialmente haviam sido formuladas 149 metas que, por meio de atividades realizadas na oficina, foram reduzidas a 37 . Posteriormente, foi feita uma consulta por meio eletrônico aos participantes da oficina, que possibilitou a hierarquização das 37 metas. Foram, então, priorizadas as 10 primeiras metas.

Esse projeto foi discutido em reuniões de câmaras técnicas que emitiram parecer para encaminhamento às plenárias. A metodologia adotada para a hierarquização das metas, bem como o resultado dessa hierarquização, também foram apresentados aos membros do comitê e aprovados em plenário. $\mathrm{O}$ andamento do projeto foi assunto das reuniões plenárias de 
10/11/2006, 12/07/2007 e 11/07/2008 e sua aprovação se deu na plenária de 08/12/2008, porém alguns ajustes se mostraram necessários.

Esse contrato não havia sido finalizado formalmente até agosto de 2011, pois uma etapa do trabalho contratado, que compreende a divisão da UGRHI 13 em sub-bacias, não teve sua aprovação oficializada pelo comitê. Esse assunto foi tratado na reunião conjunta das câmaras técnicas, realizada em 30/11/2010, e levado à plenária de 10/12/2010, porém a revisão solicitada nesta ocasião ainda não foi finalizada pela contratada.

É importante citar o comentário apresentado nas Conclusões do Relatório de Situação de 2009:

"Pode-se observar que não existe no Plano de Bacia metas e ações claras e objetivas que possam orientar as ações do Comitê como gestor. O Plano de Bacia apresenta metas muito amplas e difíceis de mensurar. Ficou evidente a necessidade de mudança conceitual na formulação do próximo Plano de Bacia que deverá indicar metas específicas, objetivas e mensuráveis que servirão de base, entre outras coisas, para a aplicação dos recursos advindos da cobrança" (CBH TJ, 2009b, p. 7).

\subsection{PROCESSO DE FORMULAÇÃO DOS CRITÉRIOS DA COBRANÇA PELO USO DOS RECURSOS HÍDRICOS}

O Grupo Técnico da Cobrança pelo Uso da Água (GT CA) foi montado na Reunião da Câmara Técnica de Planejamento e Gestão (CT PG), de 14/06/2007, a partir das inscrições dos interessados (CBH TJ, 2009a). Para possibilitar a participação de todos os 25 representantes inscritos, a formação deste grupo não seguiu a diretriz de representação paritária entre os três segmentos, como adotada na composição dos membros da plenária e das câmaras técnicas. Sendo assim, participaram deste grupo 13 representantes do segmento Sociedade Civil, 8 representantes do segmento Estado e 4 representantes do segmento Municípios. 
O grupo recebeu orientações externas em duas ocasiões: uma palestra ministrada pelo eng ${ }^{\circ}$ Luiz Roberto Moretti, Secretário Executivo do $\mathrm{CBH}$ PCJ, comitê que serviu de modelo para vários comitês estaduais, conforme já citado no item 5.6.10, e a apresentação dos Nove Passos para a Implantação da Cobrança, material formatado pela CRHi, da SMA.

Após 0 assunto Cobrança ter sido debatido nas plenárias do comitê em 22/11/2007 e 15/05/2008, o GT CA deu início efetivo aos seus trabalhos em 07/07/2008.

Este grupo, que chegou a contar com a participação ativa de 28 membros, realizou várias reuniões para discussão dos valores unitários, dos coeficientes ponderadores e das simulações de cobrança. Também foram realizadas reuniões abertas em várias cidades da bacia, visando divulgar o tema cobrança e discutir seus critérios com o público envolvido. Em 19/02/2009, o grupo apresentou a minuta de deliberação com a proposta para implantação da cobrança na bacia do Tietê - Jacaré, em reunião conjunta das CTs de Planejamento e Gestão, Recursos Naturais, Saneamento, Águas Subterrâneas e Educação Ambiental, e, em 10/03/2009, para aprovação na plenária do comitê (CBH TJ, 2009a).

Após análise em reunião conjunta das CTs de Planejamento, Assuntos Jurídicos e Institucionais e de Cobrança do CRH, em 04/11/2009, foram feitas algumas alterações na deliberação e no Relatório de Fundamentação da Cobrança, por recomendação dos membros destas câmaras, e encaminhados para aprovação na reunião plenária do $\mathrm{CRH}$ em 10/12/2009. Estes documentos foram novamente submetidos à aprovação da plenária deste comitê em 17/12/2009 e 28/06/2010, após alterações solicitadas pelo Governo do Estado. 
Finalmente, em 10/12/2010, foi publicado no Diário Oficial o Decreto no 56.505, assinado pelo Governador do Estado, em 9 de dezembro de 2010, que aprova e fixa os mecanismos e valores a serem cobrados pelo uso dos recursos hídricos da UGRHI Tietê - Jacaré - TJ (SMA, 2011).

Vale citar que em 2009, quando este comitê submeteu sua proposta de deliberação ao $\mathrm{CRH}$, em conjunto com outros 3 comitês, somente 3 bacias paulistas já contavam com este instrumento de gestão implantado, ou em vias de implantação, para os usos urbanos em cursos d'água de domínio estadual.

\subsection{RESULTADOS OBTIDOS NOS QUESTIONÁRIOS}

Os resultados apresentados neste item referem-se exclusivamente às respostas obtidas durante a aplicação do questionário junto aos membros titulares do Comitê da Bacia Hidrográfica Tietê - Jacaré, visando levantar a opinião dos diversos atores sobre o processo participativo na gestão dos recursos hídricos do estado e, em especial, desta bacia hidrográfica.

O universo escolhido para aplicação da pesquisa, conforme já relatado no item 3.3.1, foi o plenário do $\mathrm{CBH} T \mathrm{TJ}$, isto é, os 36 membros titulares responsáveis pela aprovação de todos os assuntos em tramitação neste colegiado. Membros suplentes foram entrevistados em duas situações: um membro do segmento Sociedade Civil, que compareceu à plenária na qual a pesquisa foi apresentada e se prontificou a responder 0 questionário, e um do segmento Municípios, devido ao afastamento do titular.

Em relação à lista de representantes disponível no site do comitê, além de duas alterações de representações apontadas pela secretaria executiva, 
no segmento Estado, foram constatadas outras três substituições sem a devida notificação ao comitê, sendo uma no segmento Sociedade Civil e duas no Estado.

Do total de 36 membros, foram obtidos 28 resultados, representando assim um universo de $78 \%$, sendo 10 do segmento Sociedade Civil, 9 do segmento Municípios e 9 do Estado. A participação de cada segmento no total de participantes da pesquisa, mostrada na tabela 2 , se mostrou semelhante à parcela de $33 \%$ por segmento no universo do Comitê. Tais valores percentuais possibilitam a expansão dos resultados encontrados nesta pesquisa para o universo do comitê.

Tabela 2: Participantes na Pesquisa por Segmento

\begin{tabular}{ccc}
\hline Segmentos & Participantes & \% dos Participantes \\
\hline \hline Estado & 9 & 32 \\
Municípios & 9 & 32 \\
Sociedade Civil & 10 & 36 \\
\hline \hline Total & 28 & 100 \\
\hline
\end{tabular}

Dentre os resultados, 17 foram obtidos através de entrevistas feitas diretamente com os membros, 5 entrevistas feitas com representantes designados pelos membros e 6 respostas escritas enviadas por correio eletrônico, conforme metodologia apresentada no item 3.3. Esses valores e os percentuais que representam estão apresentados na tabela 3 .

Tabela 3: Questionários respondidos por segmento e por forma de resposta

\begin{tabular}{cccccccc}
\hline Segmentos & $\begin{array}{c}\text { Entrevistas } \\
\text { aos Membros }\end{array}$ & $\%$ & $\begin{array}{c}\text { Entrevistas a } \\
\text { Representantes }\end{array}$ & $\%$ & $\begin{array}{c}\text { Respostas por } \\
\text { Escrito }\end{array}$ & $\%$ & Resultados \\
\hline \hline Estado & 7 & 78 & - & - & 2 & 22 & 9 \\
Municípios & 3 & 33 & 5 & 56 & 1 & 11 & 9 \\
Sociedade Civil & 7 & 70 & - & - & 3 & 30 & 10 \\
\hline \hline Total & 17 & 61 & 5 & 18 & 6 & 21 & 28 \\
\hline
\end{tabular}


O tempo médio de duração das entrevistas foi de 50 minutos, porém tal duração variou de 20 a 90 minutos. As entrevistas mais longas apresentaram grande variedade e riqueza de comentários, não se prenderam diretamente às questões e aconteceram com os membros da diretoria e outros que participam do comitê há no mínimo 10 anos. Em algumas entrevistas, não foi possível obter respostas a todas as perguntas devido a interrupções ou a pouca disponibilidade de tempo do entrevistado, resultando assim totais menores de respostas a algumas questões. Em alguns casos, tais respostas foram obtidas por consulta a outras pessoas.

Para a análise dos resultados, as perguntas do questionário foram reagrupadas em blocos seguindo os tópicos levantados no item 5.6. Em algumas entrevistas, as respostas às perguntas 2.15 e 2.16 e os comentários finais, por conterem relatos relacionados a outros aspectos, foram divididos pelos itens referentes aos aspectos abordados. A nova divisão de questões resultou em 9 blocos apresentados nos itens 7.6 .1 a 7.6.9.

Para facilitar a associação das respostas obtidas às questões formuladas, a numeração dos gráficos e tabelas deste item, excepcionalmente, segue a numeração das respectivas perguntas.

\subsubsection{Informações sobre os representantes}

Para melhor identificação dos participantes da pesquisa e para traçar um perfil dos membros do CBH TJ, foram solicitadas as informações listadas no quadro 2. 
Quadro 2: Informações sobre os representantes

\begin{tabular}{|c|c|}
\hline \multirow{4}{*}{$\begin{array}{c}\text { Identificação do } \\
\text { Representante } \\
\text { (Sigilosa) }\end{array}$} & 1.2 Entidade que representa \\
\cline { 2 - 2 } & 1.5 Endereço da entidade / CEP \\
\cline { 2 - 2 } & 1.7 Telefones para contato \\
\cline { 2 - 2 } & 1.8 E-mail para contato \\
\hline \hline \multirow{3}{*}{$\begin{array}{c}\text { Perfil do } \\
\text { Representante }\end{array}$} & 1.0 Segmento que representa \\
\cline { 2 - 2 } & 1.6 Cidade da entidade que representa \\
\cline { 2 - 2 } & 1.9 Cidade em que reside \\
\cline { 2 - 2 } & 1.10 ldade \\
\cline { 2 - 2 } & 1.12 Sexo \\
\hline \hline
\end{tabular}

Conforme descrito no item 3.3.3, foi assegurado aos representantes sigilo sobre as respostas fornecidas. Por esse motivo, as 5 informações referentes à identificação do representante foram separadas das demais respostas, mantidas em total sigilo e cada questionário recebeu um número para possibilitar a continuidade da análise. Pelo mesmo motivo, a autoria dos trechos das entrevistas apresentados neste capítulo não foi citada.

Apesar de atuarem em municípios da bacia Tietê - Jacaré, 2 representantes têm local de trabalho fora dela, sendo 1 do Estado e 1 da Sociedade Civil. Um deles, o representante do segmento Estado, também reside em uma cidade fora da bacia.

A idade dos representantes foi computada em intervalos de 10 anos e apresentou uma distribuição desigual, com maior concentração nas faixas etárias mais elevadas. Conforme mostrado na tabela 1.10 e no gráfico 1.10, predominam representantes com mais de 50 anos de idade dentre 0 universo pesquisado, totalizando $53 \%$. Esse predomínio é encontrado nos segmentos Estado e Sociedade Civil, onde representam 67\% e $60 \%$ do total dos segmentos, respectivamente, valores bem superiores aos $33 \%$ 
encontrados no segmento Municípios. Neste segmento, a faixa de idade predominante é entre 40 e 50 anos, com $56 \%$ dos entrevistados.

Tabela 1.10: Distribuição dos representantes por idade e por segmento

\begin{tabular}{ccccccccc}
\hline Idade do Representante & Estado & $\%$ & Municípios & $\%$ & Sociedade Civil & $\%$ & Total $\%$ Total \\
\hline \hline até 30 anos & 1 & 11 & - & - & 2 & 20 & 3 & 11 \\
de 31 a 40 anos & - & - & 1 & 11 & 1 & 10 & 2 & 7 \\
de 41 a 50 anos & 2 & 22 & 5 & 56 & 1 & 10 & 8 & 29 \\
de 51 a 60 anos & 5 & 56 & 2 & 22 & 6 & 60 & 13 & 46 \\
acima de 61 anos & 1 & 11 & 1 & 11 & - & - & 2 & 7 \\
\hline \hline Total & 9 & 100 & 9 & 100 & 10 & 100 & 28 & 100 \\
\hline
\end{tabular}

Gráfico 1.10: Distribuição dos representantes por faixa etária

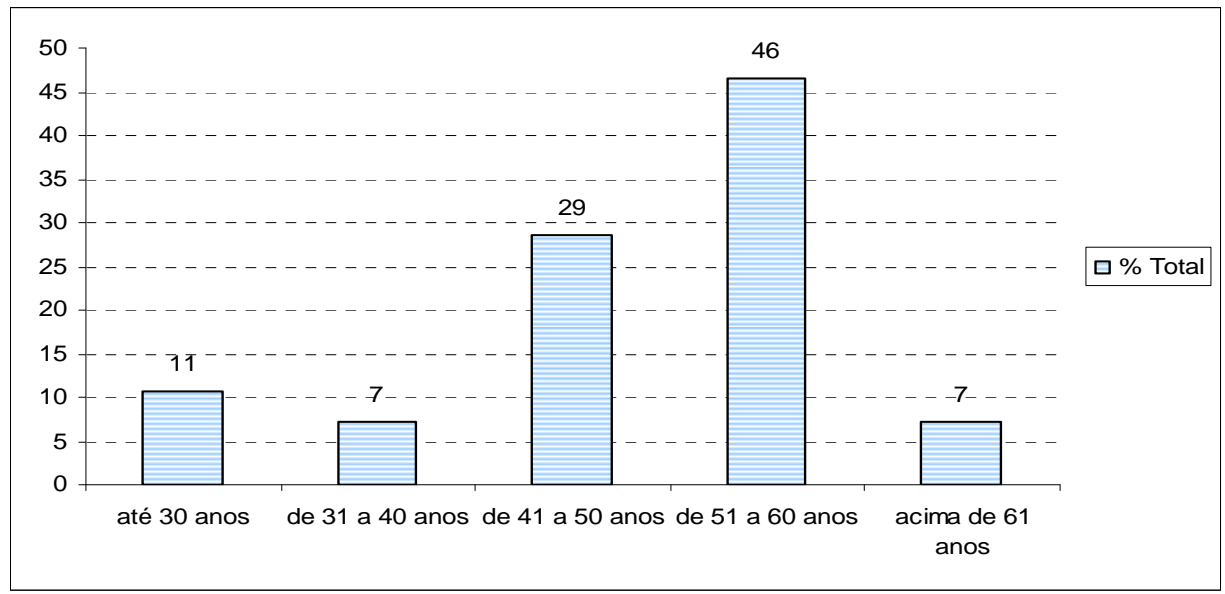

Quanto ao gênero dos representantes, há predomínio masculino na composição deste comitê, como mostra a tabela 1.12. O segmento Sociedade Civil, apesar de apresentar o maior número de mulheres no total, é representado apenas por homens nas cadeiras de titular, restando a suplência para as representantes femininas. 
Tabela 1.12: Distribuição dos representantes por gênero

\begin{tabular}{ccccccc}
\hline \multirow{2}{*}{ Segmento } & \multicolumn{2}{c}{ Titular } & \multicolumn{2}{c}{ Suplente } & \multicolumn{2}{c}{ Total } \\
& Masculino & Feminino & Masculino & Feminino & Masculino Feminino \\
\hline \hline Estado & 11 & 1 & 9 & 3 & 20 & 4 \\
Municípios & 10 & 2 & 11 & 1 & 21 & 3 \\
Sociedade Civil & 12 & - & 7 & 5 & 19 & 5 \\
\hline \hline Total & 33 & 3 & 27 & 9 & 60 & 12 \\
\hline
\end{tabular}

Além das 3 representantes femininas titulares, sendo uma delas a presidente do comitê nesta gestão avaliada, foi também entrevistada uma representante suplente da Sociedade Civil. Dentre o total de 28 entrevistas, resultam então 4 mulheres entrevistadas, representando $14 \%$ da amostra pesquisada. Além destas, dentre os 5 prefeitos que designaram pessoas de sua equipe para responder pela prefeitura, 2 eram do sexo feminino.

7.6.2 Participação dos envolvidos no planejamento e na tomada de decisão

Visando avaliar como se dá a participação dos envolvidos no planejamento e na tomada de decisão, durante as entrevistas aos membros do CBH TJ procurou-se avaliar as condições de participação dos representantes nas atividades deste comitê e sua opinião quanto à composição deste colegiado. Para isso foram feitas as perguntas do quadro 3. 
Quadro 3: Questões sobre participação dos envolvidos

\begin{tabular}{|c|c|}
\hline $\begin{array}{c}\text { Aspecto a ser } \\
\text { analisado }\end{array}$ & Perguntas feitas nas entrevistas \\
\hline \hline \multirow{2}{*}{$\begin{array}{c}\text { Condições de } \\
\text { Participação dos } \\
\text { Membros no Comitê }\end{array}$} & $\begin{array}{c}2.11 \text { Você recebe alguma ajuda financeira para } \\
\text { comparecer às reuniões? Especificar quais: } \\
\text { transporte, alimentação, diária. }\end{array}$ \\
\cline { 2 - 2 } & $\begin{array}{c}2.12 \text { Você está satisfeito com suas condições de } \\
\text { participação no comitê? }\end{array}$ \\
\cline { 2 - 2 } & $\begin{array}{c}2.15 \text { Você vê algum problema na participação de } \\
\text { algum segmento específico na gestão da bacia? } \\
\text { Citar o tipo de problema. }\end{array}$ \\
\hline Composição dos & $\begin{array}{c}2.16 \text { Você vê algum problema na composição do } \\
\text { comitê, quanto ao número de vagas e/ou quanto } \\
\text { às entidades participantes? }\end{array}$ \\
\hline \hline
\end{tabular}

\subsection{2.a Condições de participação dos membros do comitê TJ}

Ao serem questionados sobre o recebimento de ajuda financeira para o comparecimento às reuniões do comitê, apenas 2 representantes - 1 do Estado e 1 da Sociedade Civil - afirmaram não receber nenhum tipo de ajuda. Os demais recebem ajuda de diversos tipos, sendo que em 22 casos, que equivalem a $79 \%$ dos entrevistados, tal ajuda compreende transporte e alimentação e apenas 4 deles se restringem ao transporte. Os resultados obtidos estão apresentados na tabela 2.11 , onde estão apontados 3 casos em que o próprio comitê paga as despesas há duas gestões. Este comitê costuma subsidiar o fornecimento de lanches nas reuniões, tanto nas plenárias, quanto nas de câmaras técnicas, facilitando assim aos que precisam viajar para os locais de reunião, como também aos que não têm subsídio para alimentação. 
Tabela 2.11: Recebimento de ajuda financeira para ir às reuniões

\begin{tabular}{cccccc}
\hline & Estado & Municípios Sociedade Civil & Total & $\%$ \\
\hline \hline Ressarcimento dos gastos ou Diária & 2 & 4 & 3 & 9 & 32 \\
Carro da entidade ou Transporte + Alimentação ou Diária & 2 & 4 & 4 & 10 & 36 \\
Comitê paga despesas + Carro da entidade & 3 & - & - & 3 & 11 \\
Carro da entidade ou Transporte & 1 & 1 & 2 & 4 & 14 \\
Nenhuma ajuda & 1 & - & 1 & 2 & 7 \\
\hline
\end{tabular}

Em linhas gerais, os representantes estão satisfeitos com as condições de participação nas reuniões, pois os deslocamentos não são longos e as reuniões são de um período apenas, geralmente, não envolvendo pernoites. Comentou-se que no início havia problemas, mas "a gente ia na raça". Conforme respostas apresentadas na tabela 2.12, apenas 5 representantes, significando $18 \%$ da amostra, apresentaram insatisfação parcial, sendo 2 deles por problema de agenda e sobrecarga de trabalho. Os problemas apontados pelos outros 3 membros foram dificuldade para conseguir carro da entidade para os deslocamentos e/ou demora no ressarcimento de despesas de viagem.

Cabem 3 observações sobre este assunto:

- A carona é muito praticada, inclusive entre membros de diferentes segmentos e de municípios vizinhos;

- Um representante declarou ser usuário da carona, porém, quando se desloca com carro de sua instituição, está impossibilitado de retribuir, devido à regra da entidade proibindo tal prática; e

- Dois representantes da Sociedade Civil citaram a possibilidade de usar recursos de projetos em andamento na bacia.

É importante salientar que os 2 membros que apontaram não receber nenhum tipo de ajuda financeira se declararam satisfeitos com tal condição. 
Tabela 2.12: Satisfação quanto às condições para participação no comitê

\begin{tabular}{cccccc}
\hline & Estado & Municípios & Sociedade Civil & Total & $\%$ \\
\hline \hline Satisfeito & 8 & 8 & 7 & 23 & 82 \\
Médio & 1 & 1 & 3 & 5 & 18 \\
Insatisfeito & - & - & - & - & - \\
\hline
\end{tabular}

Os problemas ligados à participação dos diversos setores em reuniões do comitê apontados por mais de um membro entrevistado, em resposta à questão 2.15, foram:

- Ausência às reuniões, em especial por problemas de agenda ou outros motivos particulares, apontadas por 16 entrevistados, representando $57 \%$ do total de entrevistas;

- Dificuldade da Sociedade Civil para comparecer às reuniões por conta própria, por ser em horário de trabalho, citada por 8 pessoas, sendo 2 da Sociedade Civil, 4 representantes municipais e 2 estaduais, representando $29 \%$ das entrevistas;

- Vinculação da presença de membros dos municípios e da Sociedade Civil aos assuntos da pauta, citada por 6 pessoas, sendo 3 da Sociedade Civil, 2 representantes municipais e 1 estadual, representando $21 \%$ das entrevistas;

- Falta de prefeitos em plenárias, citada por 3 membros, sendo que uma pessoa complementou que "prefeito só vai à plenária para aprovação de projetos ou outras com questões polêmicas, como cobrança pelo uso da água";

- Vinculação da frequência de membros do Estado à importância da reunião, citada por 2 representantes da Sociedade Civil;

- "Falta comprometimento de diversas entidades", "há algumas entidades que não participam mesmo" e "as faltas são por falta de vontade", citadas por 2 representantes do Estado e 1 da Prefeitura;

- Fraca participação do Estado, citada por 2 representantes da Sociedade Civil; e

- Ausência de participação efetiva, mesmo se presente nas reuniões, por comparecer por obrigação, apontada por 2 membros estaduais. 
Além destes, também foram citados os seguintes problemas:

- Falta de estímulo aos funcionários do Estado para ir às reuniões;

- Dedicação de poucas horas de trabalho ao $\mathrm{CBH}$;

- Não aprovação pelas prefeituras para a participação de seus representantes;

- Muitas faltas devido à participação ser voluntária; e

- Ausência em reuniões com "atividades construtivas".

Quanto à participação em câmaras técnicas, foi apontado ausência de participação das universidades e excesso de faltas no geral.

É importante citar que 4 membros, representando 14\% dos entrevistados - 2 dos quais responderam ao questionário por escrito - não apontaram problemas desta espécie.

\subsection{2.b Composição do Comitê Tietê - Jacaré}

Em resposta à questão 2.16, sobre problemas na composição do comitê, 16 entrevistados, isto é, $57 \%$ do total, não apresentaram questionamentos neste sentido. Porém, os outros 12 representantes citaram vários pontos de melhoria e sugestões, além de questionamentos que dizem respeito à legislação de recursos hídricos. São eles:

- Composição tripartite, baseada na formação por igual número de representantes do Estado, Município e Sociedade Civil, questionada por 3 membros, que consideram que Estado e Município são poder público;

- Não uniformidade com comitês federais, citada por 2 pessoas;

- Ausência de instituição federal, como IBAMA, citada por 2 membros; 
- Ausência de representação de moradores de baixa renda, sociedades de bairros ou excluídos, citada por 3 membros;

- Mais vagas para ONGs - 2 representantes apontam que há apenas 1 vaga atualmente;

- "Associações como sociedade civil são poder público disfarçado", citada 2 vezes;

- Questionamento de 3 vagas para universidades, apresentado por 1 membro;

- Universidades e institutos de pesquisa, apesar de ligados ao Estado, "encaixam como sociedade civil, devido ao livre pensar" e a sua autonomia, citado por 2 entrevistados;

- Maior participação da agroindústria, sugerida por 1 membro;

- Complicação de suplência de prefeito por outro prefeito, citada por 2 membros;

- Aumento para 17 vagas por segmento para possibilitar participação de todos os municípios, sugerido por 2 entrevistados;

- Vagas para as várias sedes de instituições estaduais, sugerida 1 vez;

- Dar oportunidade de participação para todos, proporcional para os 3 segmentos, citada por 2 pessoas;

- "É importante ter perfil para isso", observado por 1 representante; e

- Comitê "agora está mais elitizado", comentado por 1 membro.

Durante as respostas a esta pergunta, alguns entrevistados trouxeram a questão da adoção da bacia hidrográfica como unidade de gestão de recursos hídricos, como apresentado no item 5.6.1 e listado como Lição 3 no item 4.5. Foram apontados 2 aspectos: nesta bacia há vários municípios com território em mais de uma bacia, o que faz com que eles precisem acompanhar mais de um comitê, citado como um problema por um entrevistado; e também há órgãos estaduais com limites de atuação diferentes dos limites das bacias, como observado por 2 pessoas. 


\subsubsection{Representatividade da entidade}

Para avaliar a representatividade das entidades que fazem parte do $\mathrm{CBH}$ TJ foram feitas as 4 perguntas constantes do quadro 4 .

Quadro 4: Questões sobre representatividade da entidade

\begin{tabular}{|c|c|}
\hline $\begin{array}{c}\text { Aspecto a ser } \\
\text { analisado }\end{array}$ & Perguntas feitas nas entrevistas \\
\hline \hline \multirow{4}{*}{ Atuação no CBH } & $\begin{array}{c}\text { 2.2 Há quanto tempo sua entidade está } \\
\text { representada neste comitê - na plenária e em } \\
\text { Câmaras Técnicas? }\end{array}$ \\
\cline { 2 - 2 } & $\begin{array}{c}\text { 2.14 Você acha que a participação de sua entidade } \\
\text { é importante para a gestão da bacia? }\end{array}$ \\
\hline \multirow{4}{*}{$\begin{array}{c}\text { Abrangência do } \\
\text { Posicionamento }\end{array}$} & $\begin{array}{c}\text { 2.9 No caso de entidade que representa uma } \\
\text { categoria: Você costuma buscar a opinião e/ou as } \\
\text { necessidades das demais entidades do seu setor } \\
\text { para levar ao comitê? }\end{array}$ \\
\cline { 2 - 2 } & $\begin{array}{c}\text { 2.10 No caso de entidade que representa uma } \\
\text { categoria: Você costuma divulgar as decisões do } \\
\text { comitê a essas entidades? }\end{array}$ \\
\hline \hline
\end{tabular}

Ao analisarmos as respostas obtidas em relação ao início da atuação das entidades no $\mathrm{CBH} T \mathrm{TJ}$, constantes da tabela 2.2, observa-se que $50 \%$ dessas entidades atuam no comitê desde a década de 1990, sendo que 11 instituições, que representam $39 \%$ da composição atual, participaram da fundação deste comitê. A entidade apontada como a mais nova é, na realidade, uma instituição já participante, cuja estrutura foi alterada.

Tabela 2.2: Início da participação de sua entidade no comitê

\begin{tabular}{cccccc}
\hline & Estado & Municípios Sociedade Civil & Total & $\%$ \\
\hline \hline Nesta gestẫo & - & - & - & - & - \\
Em 2 gestổes & 1 & - & - & 1 & 4 \\
Entre 2000 e 2007 & 1 & 4 & 1 & 6 & 21 \\
Antes de 2000 & 1 & - & 2 & 3 & 11 \\
Desde a fundaçẫo em 95 & 5 & 3 & 3 & 11 & 39 \\
\hline \hline Não sabe & - & 1 & - & 1 & 4 \\
Nẫo respondeu & 1 & 1 & 4 & 6 & 21 \\
\hline \hline
\end{tabular}


Ao responderem à questão 2.14 , todos os representantes dizem acreditar que a participação de sua entidade no comitê é importante para a gestão da bacia. Alguns afirmam que tal participação é importante tanto para a entidade, quanto para o comitê; que a atuação é importante na plenária e em câmaras técnicas; e apontam como fatores positivos a troca de experiência e a oportunidade para colocar as questões municipais. Um representante das universidades considera que a participação de seu setor "proporciona equilíbrio entre os ecologistas e o capital", pois "o professor fala pela posição na sociedade". Uma pessoa do segmento Estado complementa afirmando que acha "que ainda estamos distantes do real papel dos membros do Comitê".

As questões 2.9 e 2.10 , sobre abrangência do posicionamento, não se aplicam ao segmento Estado, pois os representantes deste segmento são indicados pelas instituições detentoras de vagas conforme distribuição do estatuto do comitê e devem representar os interesses de sua instituição. As respostas dos representantes dos Municípios apresentadas nas tabelas 2.9 e 2.10, apontam que a troca de informações entre esse segmento não é praticada, exceto em poucas ocasiões. A situação é melhor no segmento Sociedade Civil, onde a maioria dos membros costuma consultar outras entidades e também divulgar os assuntos tratados no comitê, mesmo que apenas em algumas ocasiões.

Tabela 2.9: Consulta a outras entidades do seu segmento

\begin{tabular}{ccccc}
\hline & Municípios & Sociedade Civil & Total & $\%$ \\
\hline \hline Sim & - & 3 & 3 & 23 \\
Poucas vezes & 2 & 3 & 5 & 38 \\
Nunca & 3 & 2 & 5 & 38 \\
\hline \hline Sem resposta & 4 & 2 & 6 & - \\
\hline \hline
\end{tabular}


Tabela 2.10: Divulgação a outras entidades do seu segmento

\begin{tabular}{ccccc}
\hline & Municípios & Sociedade Civil & Total & $\%$ \\
\hline \hline Sim & - & 3 & 3 & 21 \\
Poucas vezes & 4 & 2 & 6 & 43 \\
Nunca & 2 & 3 & 5 & 36 \\
\hline \hline Sem resposta & 3 & 2 & 5 & - \\
\hline \hline
\end{tabular}

\subsubsection{Representatividade do representante}

Com o objetivo de levantar a representatividade dos representantes entrevistados frente às suas entidades, procurou-se avaliar sua atuação na entidade, sua atuação no comitê e a abrangência de seu posicionamento. Para isso, foram feitas as perguntas apresentadas no quadro 5.

Quadro 5: Questões sobre representatividade do representante

\begin{tabular}{|c|c|}
\hline $\begin{array}{l}\text { Aspecto a ser } \\
\text { analisado }\end{array}$ & Perguntas feitas nas entrevistas \\
\hline Atuação na entidade & 1.4 Cargo do representante na entidade \\
\hline \multirow{3}{*}{ Atuação no CBH } & 2.3 Há quanto tempo você participa do Comitê? \\
\hline & $\begin{array}{l}\text { 2.4 Antes de atuar na plenária, você já atuou em } \\
\text { alguma Câmara Técnica? }\end{array}$ \\
\hline & $\begin{array}{l}\text { 2.13 Você acha que sua participação é importante } \\
\text { para a gestão da bacia? }\end{array}$ \\
\hline \multirow{4}{*}{$\begin{array}{l}\text { Abrangência do } \\
\text { Posicionamento }\end{array}$} & $\begin{array}{l}2.5 \text { Você recebe apoio técnico de outras pessoas } \\
\text { de sua entidade para sua atuação no comitê? }\end{array}$ \\
\hline & $\begin{array}{l}\text { 2.6 Costuma compartilhar as idéias com outras } \\
\text { pessoas de sua entidade? }\end{array}$ \\
\hline & $\begin{array}{l}\text { 2.7 Costuma buscar as opiniões dos colegas e/ou } \\
\text { superiores? }\end{array}$ \\
\hline & $\begin{array}{c}\text { 2.8 Costuma levantar as necessidades da entidade } \\
\text { para levar ao comitê? }\end{array}$ \\
\hline
\end{tabular}

Para avaliar a atuação na entidade, buscou-se levantar a posição atual dos representantes em suas instituições, através da questão 1.4. No segmento Municípios, os próprios prefeitos municipais atuam no comitê. 
Dentre os 10 representantes entrevistados da Sociedade Civil, 3 fazem parte do Conselho de Gestão ou Consultivo de sua entidade, 1 é diretor executivo, 1 é gerente, 4 são professores doutores, sendo que 1 é coordenador de curso, e 1 é vice-presidente. Dentre os 9 membros do segmento Estado, 3 ocupam o cargo de diretor regional, 2 são gerentes e 4 não ocupam cargo gerencial atualmente.

Ao avaliar o tempo de participação dos atuais membros neste comitê mostrado no gráfico 2.3, nota-se que 21 membros começaram a participar após o ano 2000, totalizando $75 \%$ dos entrevistados. Observa-se que 6 representantes, equivalentes a $21 \%$ dos entrevistados, atuam desde 1995 , ano de fundação deste colegiado, sendo que, dentre estes, o representante municipal atuava anteriormente no segmento da Sociedade Civil.

Gráfico 2.3: Tempo de participação do representante no comitê TJ

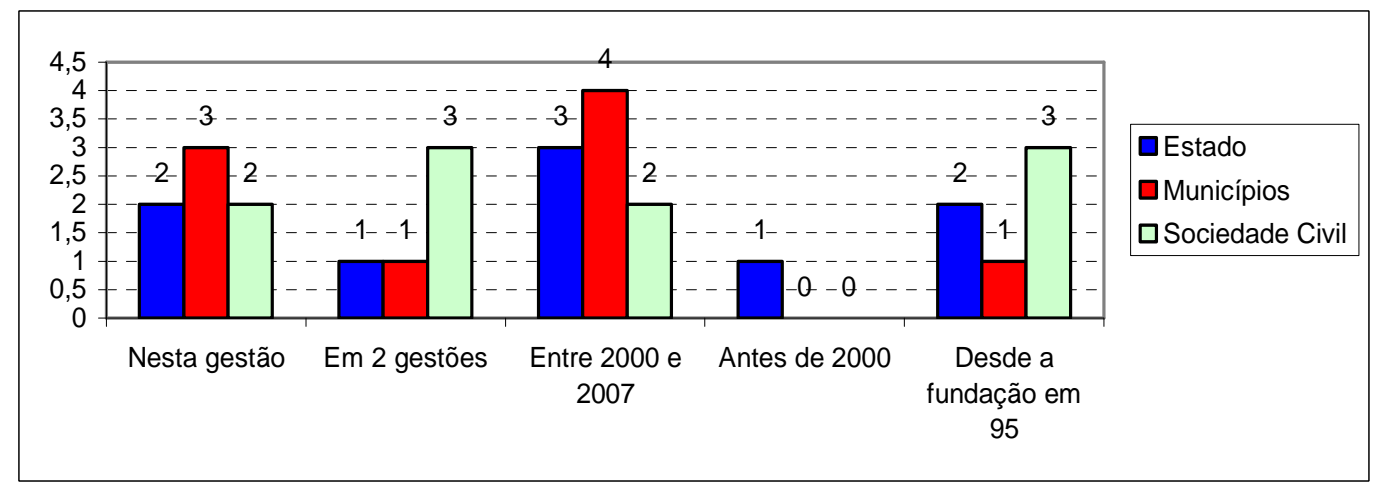

A partir das respostas à pergunta 2.4, constata-se que, dentre os 28 entrevistados, 12 membros, sendo 8 prefeitos, 3 representantes estaduais e 1 da sociedade civil, nunca atuaram em câmaras técnicas. Entre os demais, 6 atuam ou já atuaram na Câmara de Planejamento e Gestão, 4 na de Educação Ambiental, 3 na de Recursos Naturais, 2 na de Saneamento, 1 na de Águas Subterrâneas e 1 no Grupo de Cobrança. Cabe citar que a participação em câmaras técnicas do único prefeito que 
respondeu afirmativamente a esta questão, aconteceu quando este representava o segmento Sociedade Civil.

Questionados sobre a importância de sua participação no comitê para a gestão da bacia, por meio da pergunta 2.13 , todos os entrevistados responderam afirmativamente. Convém salientar algumas respostas, como a de um representante do segmento Estado: "Alguma coisa tem que ficar sem fazer, mas não posso deixar de ir, principalmente às câmaras e plenária para direcionar os parcos recursos do comitê para coisas mais relevantes". Um representante municipal considera "importante participar pela preservação da água, para pegar verbas" e para acompanhar casos de interesse do município, como a expansão de uma usina na cidade. Outro representante estadual declarou acompanhar os assuntos, mesmo não podendo ir às reuniões, através das informações enviadas pela secretaria executiva. Um membro da Sociedade Civil que começou a atuar nesta gestão considera importante participar pela vivência e para "começar a entender como funciona".

A abrangência do posicionamento dos membros do comitê foi avaliada com base nas respostas às questões 2.5 a 2.8, apresentadas nas tabelas 2.5 a 2.8. A maioria dos entrevistados declarou buscar apoio técnico, trocar ideias e opiniões e levantar necessidades de sua entidade para sua atuação no comitê, mesmo que em poucas ocasiões. No segmento dos Municípios, normalmente os prefeitos são assessorados pelo secretário do Meio Ambiente, responsável pelo departamento de águas e esgotos ou diretor do departamento de engenharia, que avalia o material enviado pelo comitê, discute internamente e os acompanha às reuniões. Nos outros segmentos, essa troca costuma ser informal e não sistematizada. Também costuma haver troca de ideias entre representantes de entidades diversas, ou ainda com o secretário executivo do comitê. 
Convém acrescentar que, dentre os 28 entrevistados, 6 membros responderam afirmativamente às 4 questões, dos quais 3 do Estado, 1 dos Municípios e 2 do segmento Sociedade Civil. Porém 4 representantes responderam negativamente a todas, sendo 2 membros estaduais, 1 municipal e 1 da Sociedade Civil.

Tabela 2.5: Recebimento de apoio técnico de pessoas de sua entidade para sua atuação no comitê

\begin{tabular}{cccccc}
\hline & Estado & Municípios & Sociedade Civil & Total & $\%$ \\
\hline \hline Sim & 5 & 4 & 4 & 13 & 48 \\
Poucas vezes & 1 & 2 & 3 & 6 & 22 \\
Nunca & 3 & 2 & 3 & 8 & 30 \\
\hline \hline Não respondeu & - & 1 & - & 1 & - \\
\hline
\end{tabular}

Tabela 2.6: Prática de compartilhar ideias com outras pessoas da entidade

\begin{tabular}{cccccc}
\hline & Estado & Municípios & Sociedade Civil & Total & $\%$ \\
\hline \hline Sim & 4 & 4 & 6 & 14 & 50 \\
Poucas vezes & 2 & 2 & 3 & 7 & 25 \\
Nunca & 3 & 3 & 1 & 7 & 25 \\
\hline \hline
\end{tabular}

Tabela 2.7: Busca por opiniões de colegas e/ou superiores

\begin{tabular}{cccccc}
\hline & Estado & Municípios & Sociedade Civil & Total & $\%$ \\
\hline \hline Sim & 4 & 2 & 6 & 12 & 44 \\
Poucas vezes & 1 & 1 & 2 & 4 & 15 \\
Nunca & 4 & 5 & 2 & 11 & 41 \\
\hline \hline Não respondeu & - & 1 & - & 1 & - \\
\hline
\end{tabular}


Tabela 2.8: Levantamento de necessidades da entidade

\begin{tabular}{cccccc}
\hline & Estado & Municípios & Sociedade Civil & Total & $\%$ \\
\hline \hline Sim & 3 & 3 & 4 & 10 & 40 \\
Poucas vezes & 1 & 1 & 3 & 5 & 20 \\
Nunca & 4 & 3 & 3 & 10 & 40 \\
\hline \hline Não respondeu & 1 & 2 & - & 3 & - \\
\hline
\end{tabular}

\subsubsection{Capacitação técnica em recursos hídricos}

Neste bloco, foram solicitadas informações sobre a instrução dos entrevistados, bem como avaliados seus conhecimentos específicos sobre recursos hídricos, conforme apresentado no quadro 6.

Quadro 6: Questões sobre capacitação técnica

\begin{tabular}{|c|c|}
\hline $\begin{array}{c}\text { Aspecto a ser } \\
\text { analisado }\end{array}$ & Perguntas feitas nas entrevistas \\
\hline \hline Instrução & 1.3 Profissão / Formação \\
\cline { 2 - 2 } & 1.11 Escolaridade \\
\hline \multirow{3}{*}{$\begin{array}{c}\text { Conhecimentos } \\
\text { Específicos }\end{array}$} & $\begin{array}{c}\text { H.1 Vocêdricos? conhece a Política Nacional de Recursos } \\
\text { Hín E Política Estadual? }\end{array}$ \\
\cline { 2 - 2 } & $\begin{array}{c}3.3 \text { Quais instrumentos de gestão dos recursos } \\
\text { hídricos você conhece? }\end{array}$ \\
\hline \hline
\end{tabular}

Os resultados encontrados referentes à instrução mostram que se trata de um público diferenciado: todos os entrevistados têm diploma universitário. Além disso, metade dos entrevistados possui especialização ou pósgraduação stricto-sensu, conforme mostra a tabela 1.11. Dentre os segmentos, a Sociedade Civil destaca-se com maior nível de instrução: apenas $30 \%$ de seus representantes apresentam somente o diploma universitário e, nos 70\% restantes, há 1 membro com especialização, 2 com mestrado, 3 com doutorado e 1 representante com pós-doutorado. 
Tabela 1.11: Grau de instrução dos representantes entrevistados

\begin{tabular}{cccccc}
\hline & Estado & Municípios Sociedade Civil & Total & $\%$ \\
\hline \hline Graduação somente & 5 & 6 & 3 & 14 & 50 \\
Especialização / MBA & 3 & 1 & 1 & 5 & 18 \\
Mestrado & 1 & - & 2 & 3 & 11 \\
Doutorado & - & 2 & 3 & 5 & 18 \\
Pós-Doutorado & - & - & 1 & 1 & 4 \\
\hline
\end{tabular}

A formação dominante no universo pesquisado é a engenharia, que representa $63 \%$ dos entrevistados. A formação dos representantes se distribui conforme tabela 1.3.

Tabela 1.3: Formação dos representantes por segmento

\begin{tabular}{ccccc}
\hline & Estado & Municípios Sociedade Civil & Total \\
\hline \hline Biologia & 1 & - & 1 & 2 \\
Direito & - & 1 & 1 & 2 \\
Engenharia & 7 & 4 & 6 & 17 \\
Farmácia & - & - & 1 & 1 \\
Fisioterapia & - & $1^{*}$ & - & $1^{*}$ \\
Geografia & - & - & 1 & 1 \\
História & - & $1^{*}$ & - & $1^{*}$ \\
Jornalismo & - & 1 & - & 1 \\
Matemática & 1 & - & - & 1 \\
Medicina & - & 1 & - & 1 \\
\hline \hline Total & 9 & $8^{* *}$ & 10 & $27^{\star *}$ \\
\hline
\end{tabular}

$\left.{ }^{*}\right)$ - uma pessoa com duas formações

$\left({ }^{*}\right)$ - uma resposta não disponibilizada

Dentre os 17 engenheiros, as especialidades dominantes são engenharia civil, com 7 representantes, e agronomia, com 5 membros. Há também 2 engenheiros elétricos, um engenheiro agrimensor, um florestal e um químico. 
Para analisar a capacitação técnica em recursos hídricos, foram avaliados os conhecimentos dos entrevistados sobre as Políticas Nacional e Estadual de Recursos Hídricos. Essas perguntas foram feitas diretamente, através da classificação em 3 níveis de conhecimento: muito bom, bom e superficial, ou indiretamente, em algumas entrevistas, durante relatos mais detalhados em resposta a outras questões. Os resultados, separados por segmento, estão apresentados na tabela 3.1 e mostram um cenário favorável.

Dentre os 26 representantes que responderam a essas perguntas, 16 conhecem muito bem ou bem a Política Nacional de Recursos Hídricos, representando $57 \%$ das respostas, conforme mostra o gráfico 3.1. Dentre os segmentos, a Sociedade Civil apresentou maior número de representantes com conhecimento muito bom ou bom. A Política Estadual de Recursos Hídricos é um pouco mais conhecida, visto que 18 membros declararam conhecê-la bem ou muito bem, representando $65 \%$ do total, como apresentado no gráfico 3.2. Dentre os que declararam conhecimento apenas superficial, 2 representantes do Estado afirmaram que trabalham com setor de meio ambiente e de saúde, e não diretamente com recursos hídricos.

Tabela 3.1: Conhecimentos específicos sobre recursos hídricos

\begin{tabular}{ccccccccc}
\hline & \multicolumn{3}{c}{ Política Nacional } & e & \multicolumn{3}{c}{ Política Estadual } \\
\hline \hline & Estado & Municípios & $\begin{array}{c}\text { Sociedade } \\
\text { Civil }\end{array}$ & Total & Estado & Municípios & $\begin{array}{c}\text { Sociedade } \\
\text { Civil }\end{array}$ & Total \\
\hline \hline Muito bom & 2 & 1 & 3 & 6 & 2 & 1 & 3 & 6 \\
Bom & 3 & 3 & 4 & 10 & 4 & 4 & 4 & 12 \\
Superficial & 4 & 2 & 2 & 8 & 3 & 1 & 2 & 6 \\
Não conhece & - & 2 & - & 2 & - & 2 & - & 2 \\
\hline \hline Não respondeu & - & 1 & 1 & 2 & - & 1 & 1 & 2 \\
\hline
\end{tabular}


Gráfico 3.1: Conhecimento sobre a Política Nacional de Recursos Hídricos

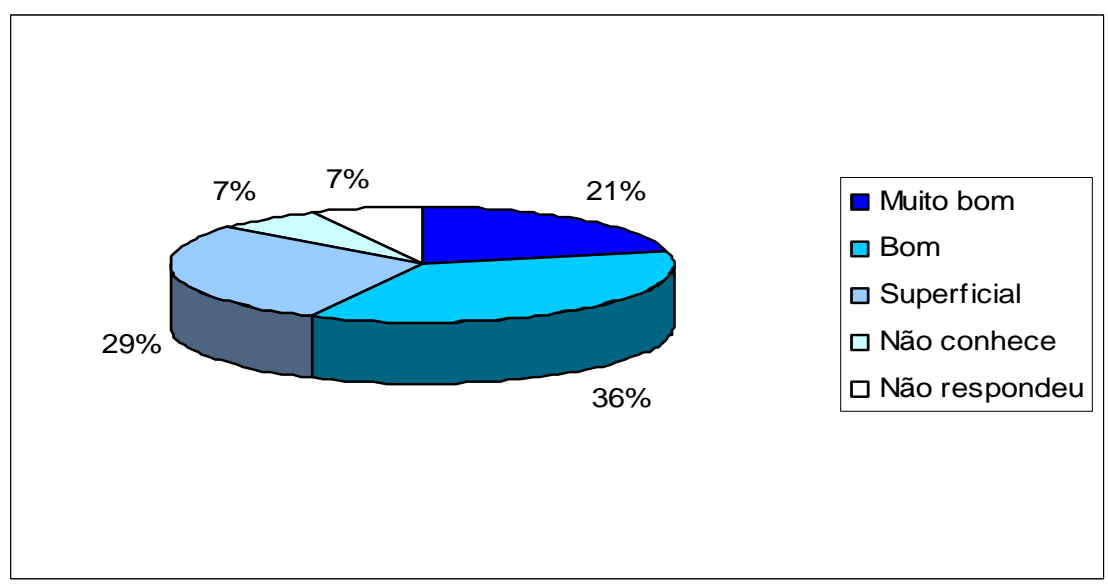

Gráfico 3.2: Conhecimento sobre a Política Estadual de Recursos Hídricos

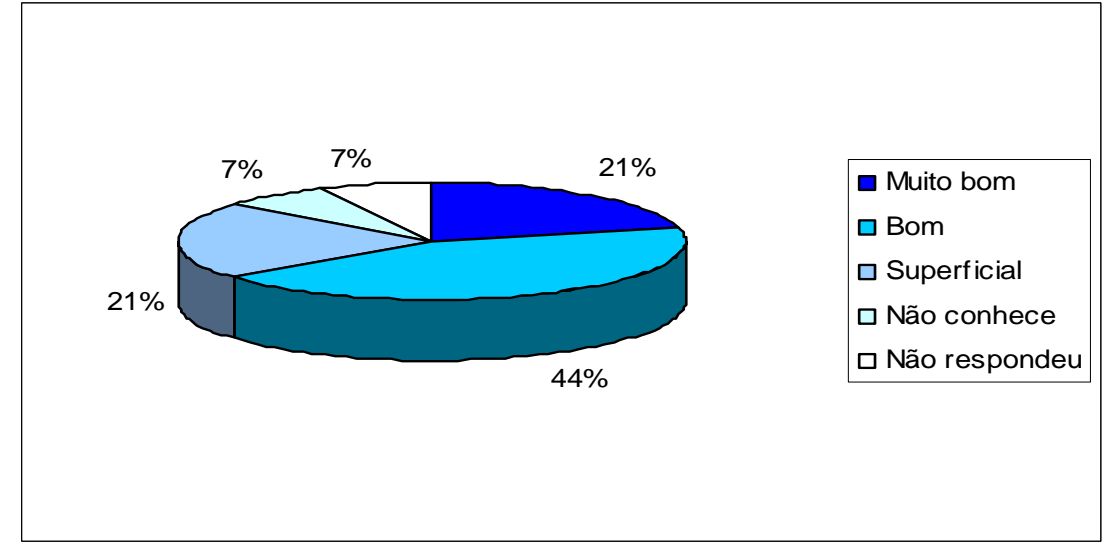

A pergunta 3.3, com a solicitação para citar instrumentos de gestão que conheciam, apresentou uma grande variação de respostas, como mostra a tabela 3.3, desde apenas 1 instrumento, citado em 2 entrevistas, até 7 instrumentos, citados em uma delas, que incluiu agência de bacia como instrumento. Em algumas entrevistas, essa solicitação não foi compreendida de imediato, tendo sido necessário colaboração para responder. Alguns instrumentos da Política Ambiental também foram citados e, em 2 situações, os entrevistados declararam conhecer legislação de outros setores por trabalharem neles. 
A Cobrança pelo uso da água resultou como o instrumento de gestão mais conhecido, tendo sido citada por 19 membros, seguido do Plano de Bacia, citado 17 vezes, e da Outorga, 16 vezes. Os instrumentos Enquadramento dos Corpos d'Água e Sistema de Informações ainda são pouco conhecidos, tendo sido citados por apenas 3 e 2 representantes, respectivamente. Os Relatórios Zero e de Situação também foram citados como instrumentos de gestão por 6 representantes.

Tabela 3.3: Citações dos instrumentos de gestão de recursos hídricos

\begin{tabular}{cccccc}
\hline & \multicolumn{3}{c}{ Citações pelos Entrevistados } & \% dentre as \\
\cline { 2 - 5 } Instrumentos de Gestão & Estado & Municípios & $\begin{array}{c}\text { Sociedade } \\
\text { Civil }\end{array}$ & Total & respostas obtidas \\
\hline \hline Plano de Bacia & 6 & 3 & 8 & 17 & 77 \\
Enquadramento dos corpos d'água & 1 & - & 2 & 3 & 14 \\
Outorga de direito de uso & 5 & 4 & 7 & 16 & 73 \\
Cobrança pelo uso da água & 6 & 5 & 8 & 19 & 86 \\
Sistema de Informações & - & - & 2 & 2 & 9 \\
Relatório Zero ou de Situação & 2 & 1 & 3 & 6 & 27 \\
Legislação de outro setor & 3 & 1 & 1 & 5 & 23 \\
Agência de Bacia & - & - & 1 & 1 & 5 \\
\hline \hline Não Respondeu & 1 & 3 & 2 & 6 & 27 \\
\hline \hline
\end{tabular}

\subsubsection{Informação e comunicação aos envolvidos}

Para avaliar o acesso à informação dos membros da plenária deste comitê, tanto relacionada a questões internas quanto externas à bacia, foi solicitado que os entrevistados respondessem as questões apresentadas no quadro 7 . 
Quadro 7: Questões sobre comunicação

\begin{tabular}{|c|c|}
\hline $\begin{array}{c}\text { Aspecto a ser } \\
\text { analisado }\end{array}$ & Perguntas feitas nas entrevistas \\
\hline \hline \multirow{4}{*}{$\begin{array}{c}\text { Comunicação Interna } \\
\text { ao CBH }\end{array}$} & $\begin{array}{c}4.1 \text { Você recebe informações sobre o andamento } \\
\text { da implantação dos instrumentos de gestão na sua } \\
\text { bacia? }\end{array}$ \\
\cline { 2 - 2 } & $\begin{array}{c}4.2 \text { Você conhece o Plano da Bacia do Tietê - } \\
\text { Jacaré? }\end{array}$ \\
\cline { 2 - 2 } & $\begin{array}{c}\text { 4.7 Você conhece os critérios definidos pelo } \\
\text { Comitê Tietê - Jacaré para a cobrança pelo uso } \\
\text { dos recursos hídricos? }\end{array}$ \\
\hline $\begin{array}{c}\text { Comunicação Externa } \\
\text { ao CBH }\end{array}$ & $\begin{array}{c}5.1 \text { Você tem informações sobre o andamento das } \\
\text { atividades dos demais comitês do estado? }\end{array}$ \\
\hline \hline
\end{tabular}

O gráfico 4.1 mostra que o recebimento de informações sobre implantação dos instrumentos de gestão neste comitê foi avaliado positivamente, visto que 25 membros responderam que recebem informações periodicamente, representando $79 \%$ das respostas obtidas. Um deles, do segmento Municípios, enfatizou que "recebem informações do comitê mais de uma vez e sempre acompanham os assuntos". Apenas 3 responderam que recebem poucas informações. Dentre eles, um representante do segmento Sociedade Civil declarou que recebe "só no âmbito das reuniões do comitê".

Gráfico 4.1: Recebimento de informações sobre andamento da implantação dos instrumentos de gestão na bacia Tietê - Jacaré

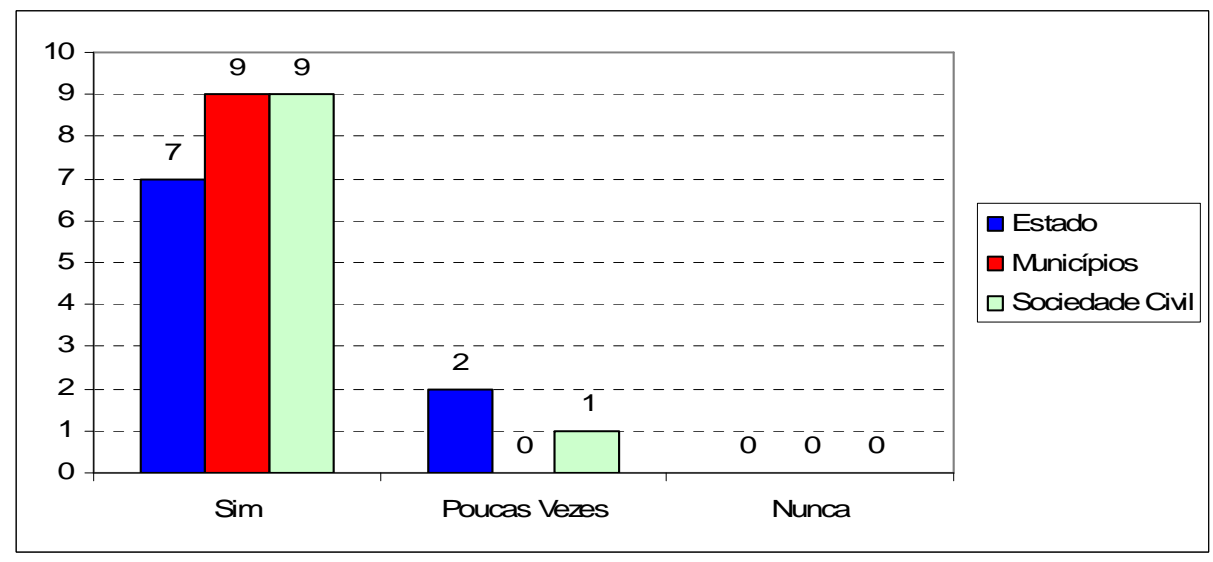


Ao serem questionados sobre seu conhecimento sobre o Plano da Bacia do Tietê - Jacaré, vários representantes relataram sobre o processo que perdurou por vários anos, conforme já relatado no item 7.4, ou alguma etapa em especial. Mesmo alguns representantes que passaram a participar recentemente do comitê comentaram sobre participação parcial na revisão do Plano ou somente sobre o recebimento dos resultados ou do $\mathrm{CD}$ final. Cabe citar o comentário de um representante da Sociedade Civil: "Não li direito, mas conheço as prioridades".

As respostas a essa pergunta, separadas por segmento, estão apresentadas no gráfico 4.2. Dentre as 27 respostas obtidas, 20 entrevistados, representando $74 \%$ das respostas obtidas, declararam que conhecem muito bem ou bem o Plano da Bacia. Dentre os 4 representantes que declararam não conhecer o Plano, há 2 membros que começaram a participar do Comitê apenas nesta gestão.

Gráfico 4.2: Conhecimento do Plano da Bacia do Tietê - Jacaré

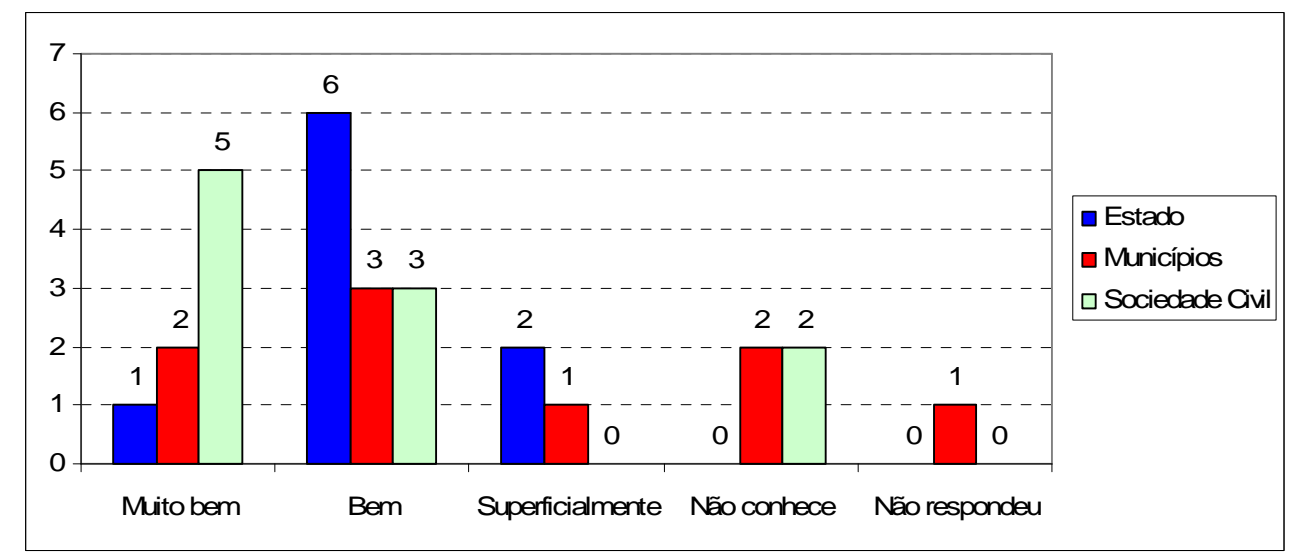

O gráfico 4.7 mostra os resultados obtidos quanto ao conhecimento sobre os critérios definidos pelo CBH TJ para a cobrança pelo uso da água, apontando que 21 membros entrevistados responderam que conhecem muito bem ou bem os critérios formulados para implantação da cobrança na bacia, o que representa $77 \%$ das respostas obtidas. Apenas 2 
entrevistados declararam não conhecer tais critérios, sendo que um deles, do segmento Estado, começou a atuar no comitê apenas no ano de 2010.

Gráfico 4.7: Conhecimento dos critérios definidos pelo Comitê Tietê Jacaré para a Cobrança pelo Uso da Água

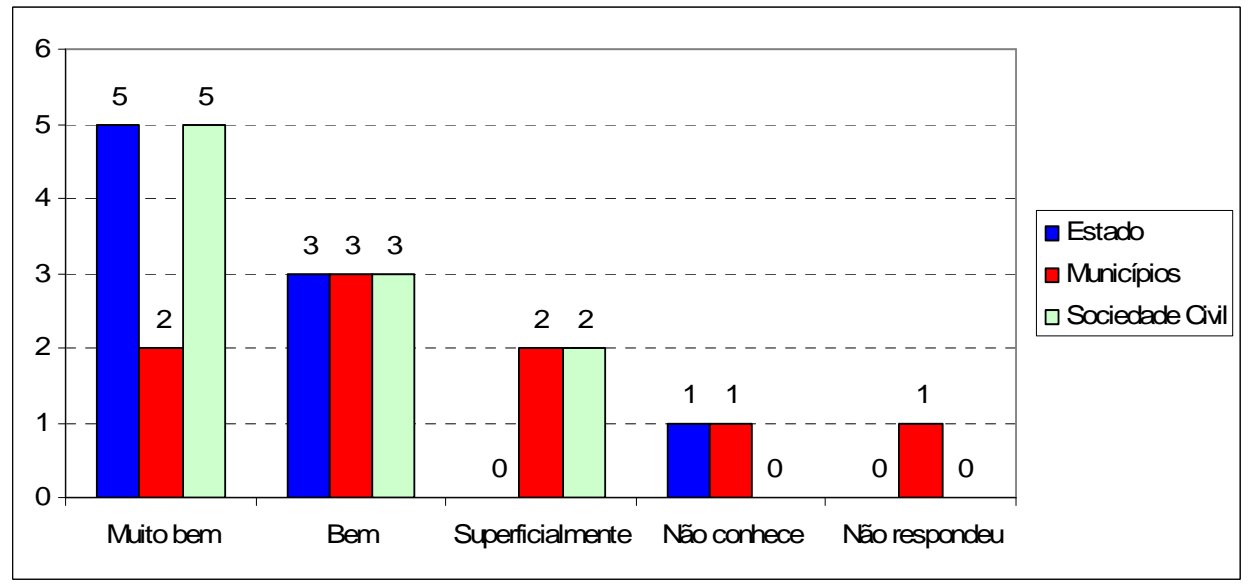

Ao ampliarmos o questionamento sobre informações recebidas dos demais comitês do Estado, o quadro encontrado é mais desfavorável, como mostra o gráfico 5.1. Apenas 11 membros, representando $39 \%$ das respostas obtidas, declararam receber periodicamente informações. Dentre as formas apontadas para tal, citaram "revistas e compêndios"; o informativo Correnteza; o evento anual Diálogo Interbacias de Educação Ambiental em Recursos Hídricos; o Fórum dos Comitês, que reúne duas vezes por ano as diretorias dos comitês estaduais; o Encontro dos Comitês, cuja $2^{\text {a }}$ edição foi realizada em Bauru; e a participação na elaboração do Plano Estadual de Recursos Hídricos.

Grande parte dos entrevistados, totalizando $43 \%$, declararam receber poucas informações dos demais comitês. Destes 12 representantes, 3 membros declararam participar também do CBH Tietê - Batalha e 2 do CBH Mogi-Guaçu, além de 2 do segmento Municípios que declararam só conhecer o que é comentado nas reuniões do CBH TJ. Alguns declararam acompanhar também o andamento do CBH PCJ. 
É importante reproduzir os comentários de um representante do Estado, cuja secretaria realiza encontros periódicos entre seus empregados participantes do Sistema de Gerenciamento de Recursos Hídricos nos diversos comitês do estado. Ele costuma receber informações dos comitês PCJ, Pardo, Tietê - Batalha e Paraíba do Sul, porém se ressente ao desconhecer o que acontece nos $\mathrm{CBHs}$ vizinhos Sorocaba / Médio Tietê e Médio Paranapanema. E afirma: "Não há fluxo de informações entre os comitês, eles são muito isolados. A troca de informações poderia ser mais rica. Seria muito importante haver um mecanismo para essa troca". Essa falta de contato com outras bacias é também sentida pelos que declararam não receber informações.

Gráfico 5.1: Recebimento de informações sobre andamento das atividades dos comitês do Estado de São Paulo

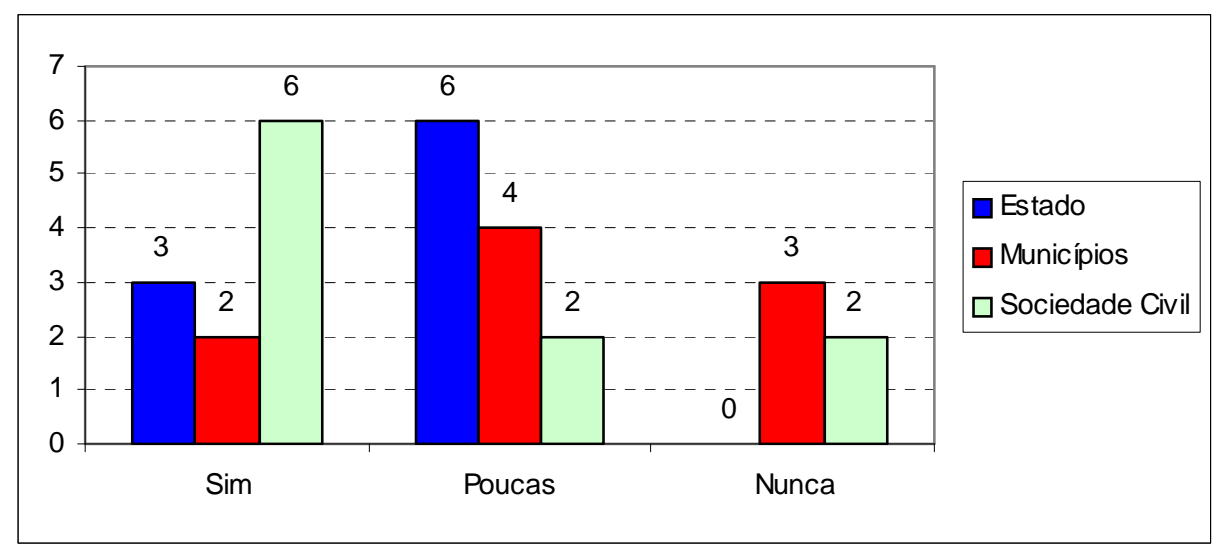

\subsubsection{Processo de estabelecimento do Plano de Bacia}

Para levantar a opinião dos representantes do CBH TJ sobre o processo de estabelecimento da nova versão do Plano de Bacia, foram feitas as perguntas constantes do quadro 8 durante as entrevistas junto aos representantes do comitê. Cabe lembrar que 4 membros declararam não conhecer o Plano de Bacia, conforme relatado no item 7.6.6, além de 
outros que não conhecem o processo de revisão do Plano por terem iniciado recentemente sua participação neste comitê. Isso dificultou, ou até mesmo impossibilitou a resposta às questões deste bloco, acarretando assim um número menor de resultados.

Quadro 8: Questões sobre o processo do Plano de Bacia

\begin{tabular}{|c|c|}
\hline $\begin{array}{c}\text { Aspecto a ser } \\
\text { analisado }\end{array}$ & Perguntas feitas nas entrevistas \\
\hline \hline $\begin{array}{c}\text { Satisfação no } \\
\text { Processo }\end{array}$ & $\begin{array}{c}4.3 \text { Você acha que este plano demonstra os } \\
\text { principais problemas e demandas da bacia? }\end{array}$ \\
\hline & $\begin{array}{c}4.4 \text { Sua entidade participou da elaboração desse } \\
\text { plano? }\end{array}$ \\
\cline { 2 - 2 } Participação no \\
Processo & 4.5 As demais entidades do comitê participaram \\
& da elaboração do plano? \\
\cline { 2 - 2 } & $\begin{array}{c}\text { 4.6 Você considera que a participação dos } \\
\text { diversos segmentos foi importante para a } \\
\text { qualidade do Plano de Bacia? }\end{array}$ \\
\hline \hline
\end{tabular}

Ao serem questionados se os principais problemas e demandas da bacia foram levantados pela nova versão do plano, apenas 1 representante da Sociedade Civil discordou totalmente, conforme mostra a tabela 4.3. Dentre os demais, 9 apontaram que foram levantados pelo Plano, representando $47 \%$ das respostas obtidas, e 9 acreditam que apenas parcialmente.

Tabela 4.3: Demonstração dos principais problemas e demandas da bacia pelo Plano de Bacia

\begin{tabular}{cccccc}
\hline & Estado & Municípios & Sociedade Civil & Total & $\%$ \\
\hline \hline Sim & 4 & 3 & 2 & 9 & 47 \\
Médio & 4 & 2 & 3 & 9 & 47 \\
Não & - & - & 1 & 1 & 5 \\
\hline \hline Não respondeu & 1 & 4 & 4 & 9 & - \\
\hline
\end{tabular}

Com base nas respostas obtidas para as questões 4.4 e 4.5, apresentadas nas tabelas 4.4 e 4.5, é possível afirmar que houve participação 
significativa das entidades componentes do CBH TJ. Dentre os membros que responderam a tais questões, 13 declararam que suas próprias entidades participaram do processo, como também 13 declararam que houve participação das diversas instituições deste comitê, além de 6 membros que apontaram participação parcial nos dois casos.

Tabela 4.4: Participação de sua entidade na elaboração do Plano de Bacia

\begin{tabular}{cccccc}
\hline & Estado & Municípios & Sociedade Civil & Total & $\%$ \\
\hline \hline Sim & 4 & 4 & 5 & 13 & 52 \\
Médio & 3 & - & 3 & 6 & 24 \\
Não & 2 & 4 & - & 6 & 24 \\
\hline \hline Não respondeu & - & 1 & 2 & 3 & - \\
\hline
\end{tabular}

Tabela 4.5: Participação das demais entidades na elaboração do Plano

\begin{tabular}{cccccc}
\hline & Estado & Municípios & Sociedade Civil & Total & $\%$ \\
\hline \hline Sim & 3 & 5 & 5 & 13 & 68 \\
Médio & 3 & 1 & 2 & 6 & 32 \\
Não & - & - & - & - & - \\
\hline \hline Não respondeu & 3 & 3 & 3 & 9 & - \\
\hline
\end{tabular}

O reconhecimento da importância da participação de entidades dos diversos segmentos nas atividades de elaboração do Plano de Bacia foi apontado por 13 membros entrevistados, representando $68 \%$ das respostas obtidas a esta questão, conforme mostra a tabela 4.6. Além dos 5 representantes que acreditam apenas parcialmente na importância desta participação, foi obtida uma resposta negativa, vinda da mesma pessoa que respondeu negativamente à questão 4.3. 
Tabela 4.6: Importância da participação dos diversos segmentos para a qualidade do Plano de Bacia

\begin{tabular}{cccccc}
\hline & Estado & Municípios & Sociedade Civil & Total & $\%$ \\
\hline \hline Sim & 4 & 4 & 5 & 13 & 68 \\
Médio & 2 & 2 & 1 & 5 & 26 \\
Não & - & - & 1 & 1 & 5 \\
\hline \hline Não respondeu & 3 & 3 & 3 & 9 & - \\
\hline
\end{tabular}

7.6.8 Processo de formulação dos critérios da cobrança

Procurou-se levantar a opinião dos entrevistados sobre o processo de formulação dos critérios para a implantação da cobrança nesta bacia, tanto em relação à satisfação com os critérios definidos, quanto em relação à participação dos diversos segmentos no processo. Para isso, foram formuladas 3 questões, conforme mostra o quadro 9.

Quadro 9: Questões sobre o processo da cobrança

\begin{tabular}{|c|c|}
\hline $\begin{array}{c}\text { Aspecto a ser } \\
\text { analisado }\end{array}$ & Perguntas feitas nas entrevistas \\
\hline \hline $\begin{array}{c}\text { Satisfação no } \\
\text { Processo }\end{array}$ & $\begin{array}{c}\text { 4.8 Sua entidade está satisfeita com os critérios } \\
\text { formulados? }\end{array}$ \\
\hline $\begin{array}{c}\text { Participação no } \\
\text { Processo }\end{array}$ & $\begin{array}{c}4.9 \text { Você, ou outro representante de sua entidade, } \\
\text { participou do GT Cobrança? }\end{array}$ \\
\cline { 2 - 2 } & $\begin{array}{c}\text { 4.10 Você considera que a participação dos } \\
\text { diversos segmentos neste processo foi } \\
\text { significativa? }\end{array}$ \\
\hline \hline
\end{tabular}

Com base nas respostas computadas na tabela 4.8, pode-se afirmar que os critérios formulados atingiram um alto grau de satisfação: 21 membros declararam que suas entidades estão satisfeitas com tais critérios e apenas 2 representantes, equivalentes a 9\% das respostas obtidas, declararam satisfação média. Um deles, representando um município usuário, declara que "é bom para ter mais recursos, (...) para organizar o 
irregular", mas demonstra preocupação por não saber "como o município irá atuar". O outro, representante da Sociedade Civil, apresentou preocupação quanto ao impacto na tarifa de água: "será que um grande consumidor irá sentir? Eles podem ser penalizados".

Tabela 4.8: Satisfação de sua entidade com os critérios formulados para a cobrança pelo uso da água

\begin{tabular}{cccccc}
\hline & Estado & Municípios Sociedade Civil & Total & $\%$ \\
\hline \hline Sim & 7 & 6 & 8 & 21 & 91 \\
Médio & - & 1 & 1 & 2 & 9 \\
Não & - & - & - & - & - \\
\hline \hline Não respondeu & 2 & 2 & 1 & 5 & - \\
\hline
\end{tabular}

Dentre as 25 respostas obtidas sobre a participação neste processo, apresentadas na tabela 4.9, foram obtidas 12 respostas positivas, inclusive de dois participantes mais novos. Um deles declarou ter participado da revisão do Relatório de Fundamentação, possibilitando assim bom conhecimento dos critérios definidos.

Tabela 4.9: Participação sua ou de sua entidade no GT Cobrança

\begin{tabular}{cccccc}
\hline & Estado & Municípios & Sociedade Civil & Total & $\%$ \\
\hline \hline Sim, você & 4 & - & 1 & 5 & 20 \\
Sim,outro representante & 1 & 3 & 1 & 5 & 20 \\
Sim, mas não falou quem & - & - & 2 & 2 & 8 \\
Não participou & 3 & 5 & 5 & 13 & 52 \\
\hline \hline Não respondeu & 1 & 1 & 1 & 3 & - \\
\hline
\end{tabular}

Apesar de 20 pessoas, equivalentes a $71 \%$, considerarem significativa a participação dos diversos segmentos no processo de formulação dos critérios de cobrança, conforme mostra a tabela 4.10, 2 representantes não concordam plenamente com essa opinião. Um deles, representante da Sociedade Civil, considera que "faltou participação de consumidor 
final. Ele não foi ouvido". A outra pessoa, representante municipal, considera que "a cobrança ainda não se tornou pública. Ainda não está claro na cabeça das pessoas. Ainda não a entenderam, apesar de já ter sido noticiada várias vezes".

Tabela 4.10: Participação significativa dos diversos segmentos no processo de formulação dos critérios de cobrança

\begin{tabular}{cccccc}
\hline & Estado & Municípios & Sociedade Civil & Total & $\%$ \\
\hline \hline Sim & 8 & 6 & 6 & 20 & 71 \\
Médio & - & 1 & 1 & 2 & 7 \\
Não & - & - & - & - & - \\
\hline \hline Não respondeu & 1 & 2 & 3 & 6 & 21 \\
\hline
\end{tabular}

\subsubsection{Resultado final}

Para avaliar a satisfação dos entrevistados com a gestão de recursos hídricos atual na bacia do Tietê - Jacaré e no Estado de São Paulo, como também sua opinião sobre a satisfação de sua entidade, foram feitas as perguntas constantes do quadro 10 , apresentado a seguir.

Quadro 10: Questões sobre satisfação com a gestão das águas

\begin{tabular}{|c|c|}
\hline $\begin{array}{l}\text { Aspecto a ser } \\
\text { analisado }\end{array}$ & Perguntas feitas nas entrevistas \\
\hline \multirow{2}{*}{$\begin{array}{l}\text { Satisfação com a } \\
\text { Gestão Local }\end{array}$} & $\begin{array}{l}\text { 4.11 Você está satisfeito com a gestão atual dos } \\
\text { recursos hídricos desta bacia? Justifique sua } \\
\text { resposta. }\end{array}$ \\
\hline & $\begin{array}{l}\text { 4.12 Sua entidade está satisfeita com a gestão } \\
\text { atual dos recursos hídricos desta bacia? Justifique } \\
\text { sua resposta. }\end{array}$ \\
\hline \multirow{2}{*}{$\begin{array}{l}\text { Satisfação com a } \\
\text { Gestão Regional }\end{array}$} & $\begin{array}{l}5.2 \text { Você está satisfeito com a gestão de recursos } \\
\text { hídricos no Estado? Justifique sua resposta. }\end{array}$ \\
\hline & 5.3 E sua entidade? Justifique sua resposta. \\
\hline
\end{tabular}

Conforme mostra o gráfico 4.11, 7 representantes municipais, 3 estaduais e 3 da Sociedade Civil estão satisfeitos com a gestão dos recursos 
hídricos praticada atualmente na bacia. Dentre as justificativas apresentadas, destacam-se:

- "Sistema colegiado democrático";

- "Um dos comitês mais de vanguarda, é bem ativo";

- $\quad$ CBHs PCJ e PS estão mais adiantados, mas está legal;

- $\quad$ CBH TJ está bem, com disposição de sempre melhorar;

- "O Comitê definiu suas prioridades e está bem focado";

- "O comitê vem trabalhando a bom termo com os recursos disponíveis";

- "Medidas dentro do que é cabível para o pessoal gestor do comitê";

- É o único comitê que teve eleição disputada para presidente;

- A conscientização aumentou; e

- "Essa região é abençoada, que região linda".

A condução das reuniões e do comitê foi elogiada por 4 representantes, pois:

- "Sempre sai de lá com algum resultado";

- "É reunião que resolve"; e

- A reunião não fica chata, "não dão brecha pra ficar em lero-lero".

Entre as justificativas dos que não estão completamente satisfeitos, estão:

- "Acho que deveríamos aprofundar no que realmente são os objetivos da bacia, estamos ainda um pouco limitados apenas em nos reunirmos para discussão de assuntos emergenciais. (...) Acho que temos avançado muito, mas ainda falta muito para atingirmos todos os objetivos relacionados pelo Estatuto do Comitê";

- "Penamos para algumas coisas que quisemos fazer por conta própria, sem copiar do PCJ, e levou mais tempo"; 
- O comitê não decide questões relevantes sobre poluição das águas. Ainda se restringe a assuntos de saneamento;

- Os critérios para distribuição de recursos são pouco flexíveis;

- Falta fiscalização mais atuante - há muita captação para irrigação;

- Câmaras técnicas poderiam ser mais ativas e produtivas; e

- Só há interesse em captação de recursos e análise de EIA/RIMA.

Porém, 3 membros se declaram insatisfeitos com a gestão das águas na bacia. Suas justificativas para tal são:

- Tudo é muito moroso;

- Falta um arquivo para condensar tudo, um banco de dados no comitê;

- O comitê deveria trabalhar junto aos municípios nos Planos Municipais de Saneamento e participar das discussões, pois precisa estar de acordo com o Plano de Bacia, e deveria cobrar mais os envolvidos com planos de resíduos sólidos também;

- "Hoje o comitê é igual a um balcão. Todo ano prefeituras, ONGs e universidades submetem projetos, como demanda espontânea, as câmaras analisam, mas não há uma atuação pró-ativa do comitê. Precisaria diagnosticar as necessidades da bacia e ir atrás para resolver, para resultar em benefícios para a sociedade"; e

- "A agência de bacia é fundamental".

Gráfico 4.11: Satisfação do representante com a gestão das águas da bacia

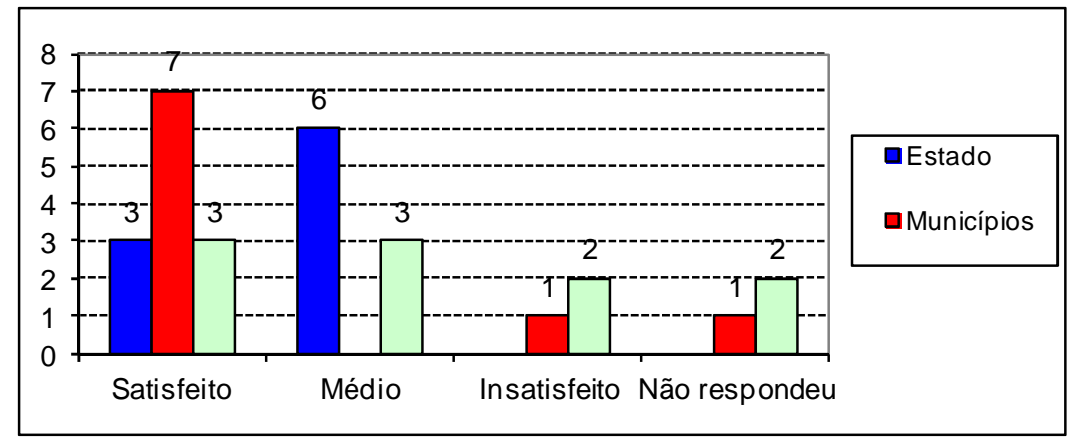


Apenas 16 representantes responderam sobre a satisfação da entidade que representam com a gestão de recursos hídricos da bacia, conforme mostra o gráfico 4.12. Dentre os 4 que declararam que suas entidades não estão completamente satisfeitas, destaca-se a justificativa apresentada por uma delas que "poderíamos aprofundar mais nas questões".

Gráfico 4.12: Satisfação de sua entidade com a gestão das águas da bacia

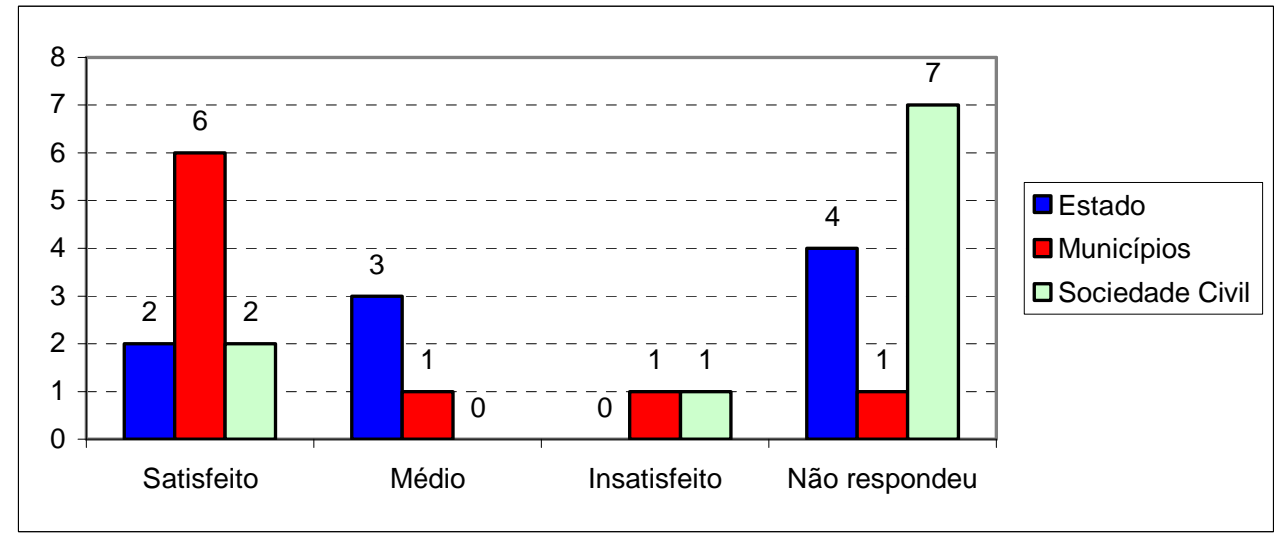

Dentre as justificativas apresentadas pelos 11 representantes que se declararam satisfeitos com a gestão de recursos hídricos no Estado de São Paulo, conforme aponta o gráfico 5.2, duas delas exprimem as razões apresentadas pelos demais:

- "Não tem como ser acelerado. É mais interessante ser participativo. Toda a sociedade tem oportunidade de participar. Os meios de comunicação também participam. Saem notícias em jornais. A sociedade civil questiona, mas existe participação. Isso é o mais importante. Houve grande evolução com os comitês. Tem que ser por bacia, não mais por municípios"; e

- "A gestão de recursos hídricos no Estado é das mais antigas, serviu de modelo pro Brasil, é muito interessante como democratização de gestão pública e para distribuição de recursos públicos. Hoje os recursos são poucos, mas a experiência demonstrou eficiência e importância. Poderia ser expandida para 
outros segmentos, como saúde, educação, transporte, ou meio ambiente: usar a estrutura dos comitês para fazer a gestão ambiental mais democrática".

Os 14 representantes que se declararam parcialmente satisfeitos citaram diversos problemas ainda encontrados na bacia e salientaram as dificuldades de gestão. Dentre elas destacam-se:

- "Há desarticulação da gestão das bacias e dos municípios. Precisa planejamento de manejo e uso do solo, com participação da Secretaria da Agricultura. (...) Falta articulação entre as secretarias estaduais. Duplica energia, desperdiça recursos. Recursos hídricos não é meio ambiente? Tinha que estar junto. DAEE cuida da quantidade da água, da disponibilidade hídrica e CETESB faz qualidade da água. Essas coisas são interligadas. Qualidade é função da quantidade também. (...) A visão é muito do corpo hídrico ainda, e não da bacia como território, do solo da bacia";

- "Acho que já houve grandes avanços. Agora precisa discutir daqui pra frente. Falta dinheiro pros comitês. Falta implementação efetiva da cobrança. Falta vontade política dos governos estaduais para utilizar os comitês para mobilizar. Os prefeitos estão desmotivados. São Paulo está na frente, a estratégia adotada é boa, está mais adiantado. O nível de organização é bom. Precisa maior preocupação com a área de saneamento básico por inteiro, incluindo drenagem, erosão e resíduos sólidos";

- "Algumas atitudes são muito demoradas, na parte de aplicação da legislação que beneficia e protege os recursos hídricos";

- Os comitês estão implantados, com Planos de Bacia, a linha mestra está boa, mas "precisa melhorar a gestão. Precisa ser mais sério. Precisa ter pessoas engajadas com tempo e disposição para fazer";

- "A sociedade civil vê mais a gestão", mas os municípios se interessariam mais se tivesse mais recursos; $\mathrm{e}$

- No comitê Tietê - Batalha são mais atuantes, atingem um grupo maior. "Os prefeitos de lá são mais engajados". 
Gráfico 5.2: Satisfação do representante com a gestão das águas no Estado

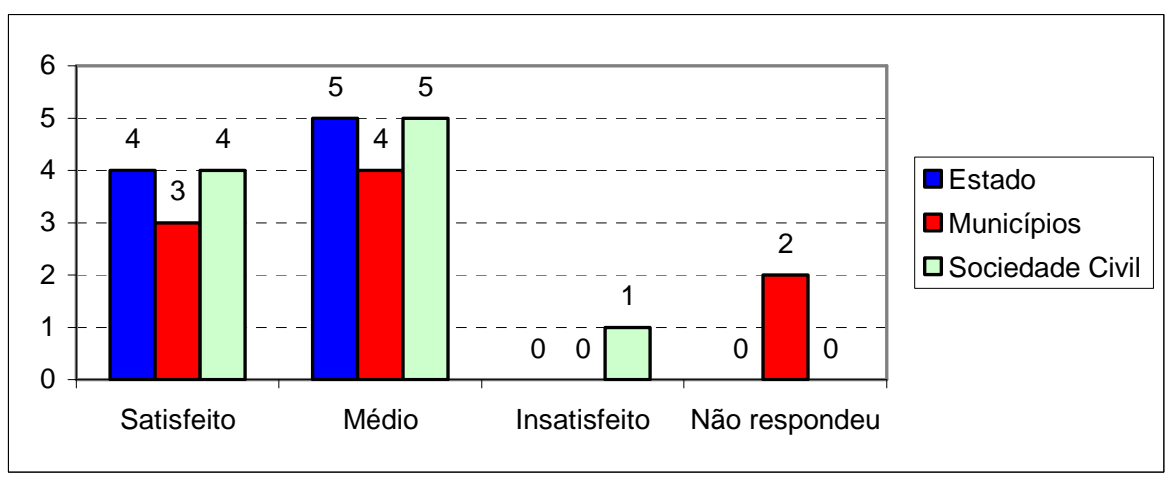

O gráfico 5.3 apresenta as respostas dos entrevistados sobre a satisfação de suas entidades com a gestão de recursos hídricos no estado. Apenas 10 representantes responderam, dos quais 6 positivamente. Estes ressaltaram a importância dos comitês e sua colaboração para a qualidade da água, e que "a representação tripartite é perfeita; as câmaras impedem que haja populismo, e sim uma forma democrática". Apesar de afirmar que seu município está satisfeito, um representante municipal, após citar alguns problemas enfrentados, enfatiza que 0 Estado deveria fomentar mais ações para solucioná-los e que "é necessário usar comunicação de massa, pois a população não tem formação ainda".

Uma das 3 pessoas que declararam satisfação parcial, justifica que "existe a necessidade de aprofundamento em relação à finalidade do comitê e efetivar ações que visem estes objetivos".

É importante transcrever a justificativa apresentada pelo representante da Sociedade Civil que se declarou insatisfeito nas 4 questões: "Os comitês em geral vêm sendo usados como instrumento político regional, quando deveria ser uma organização técnica-administrativa para a gestão da bacia. Não há o conhecimento sequer da qualidade da água, os dados são superficiais e subjetivos". 
Gráfico 5.3: Satisfação de sua entidade com a gestão das águas no Estado

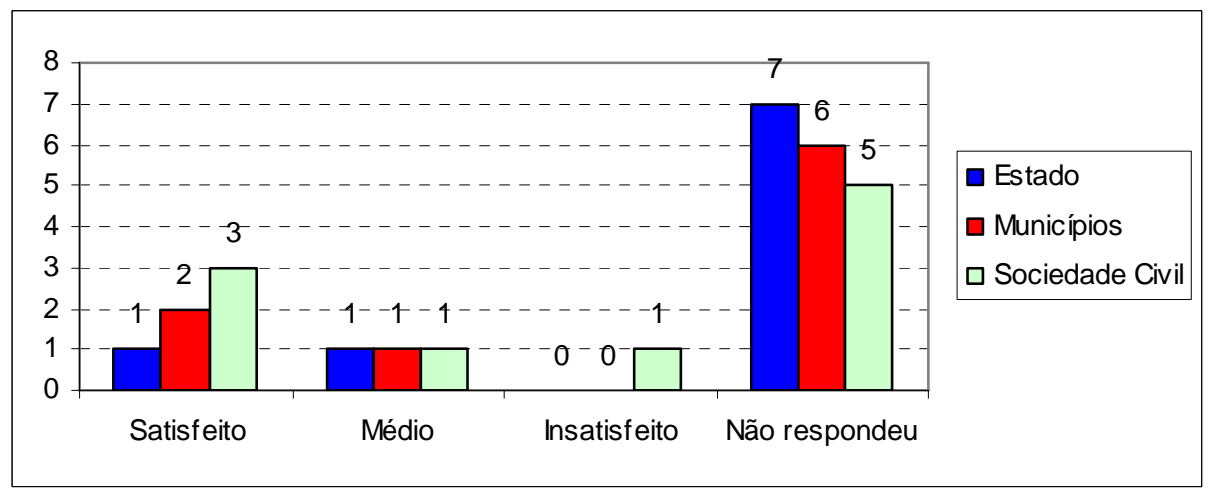

\subsection{ANÁLISE DOS RESULTADOS DO ESTUDO DE CASO}

Os resultados das entrevistas aos membros do Comitê Tietê - Jacaré, apresentados no item anterior, foram analisados em conjunto com as informações obtidas na pesquisa documental, levando também em consideração o conhecimento obtido por esta pesquisadora ao participar das 4 reuniões relacionadas no item 3.3.6. Esta análise está apresentada a seguir, observando a mesma divisão de assuntos adotada no item 7.6.

\subsubsection{Informações sobre os representantes}

O estatuto do CBH TJ estipula que os representantes do Estado devem, prioritariamente, exercer suas funções em unidades regionais existentes na UGRHI, mas deixa essa questão em aberto para os membros do segmento Sociedade Civil. As informações sobre local de trabalho mostram que dois membros trabalham fora da bacia: um representante de uma instituição estadual, cuja sede fica fora da bacia, porém sua área de atuação envolve municípios da bacia, e um representante da Sociedade Civil, cuja entidade atua no estado todo, com sede na capital. 
Dentre as informações levantadas sobre os representantes, cabe destacar os dados obtidos sobre gênero e idade dos membros deste comitê. No universo pesquisado há predomínio de representantes do sexo masculino e um grande número de representantes com mais de 50 anos de idade, em especial nos segmentos Estado e Sociedade Civil. Apesar de poder contar com a grande experiência profissional destes membros, há um maior risco de perder conhecimento e experiência com a saída de vários profissionais ocasionada por aposentadoria. Este resultado justifica a preocupação demonstrada pela pesquisa EMPINOTTI (2010), citada no item 5.6.7, quanto à preocupação em fazer seguidores nos comitês. Cabe citar que um dos entrevistados do segmento Estado, o secretário executivo da gestão 2009 - 2011, desligou-se do comitê no início da gestão 2011 2013 devido a sua aposentadoria.

7.7.2 Participação dos envolvidos no planejamento e na tomada de decisão

Ao analisarmos os resultados referentes às condições de participação dos membros do comitê TJ, nota-se problemas localizados de dificuldade para uso do carro da entidade e demora em ressarcimento de despesas. Apesar dessas dificuldades, a prática da carona e o fornecimento de lanches pelo comitê, não só solucionam boa parte destes problemas, como proporcionam uma maior integração entre seus membros.

Percebe-se, porém, que os problemas decorrentes de disponibilidade de agenda são mais frequentes e provocam um alto número de faltas em reuniões. Membros dos três segmentos declararam problemas de agenda e de acúmulo de atividades, deles próprios ou de colegas. Destaca-se aqui a dificuldade dos representantes da Sociedade Civil que, por trabalharem em empresas privadas ou públicas, geralmente diferentes 
das instituições que representam no comitê, teriam mais problemas em se ausentar para as atividades do comitê em horário de trabalho. $O$ excesso de faltas também é provocado pelo baixo comprometimento de alguns representantes, ou ainda de suas entidades, dificultando 0 comparecimento de seus profissionais. Visando minimizar o número de faltas, foi sugerida a implantação de algum critério para a perda da vaga do membro, ou até mesmo da entidade, após um limite estipulado de faltas.

Mesmo presentes nas reuniões, alguns membros do comitê não participam efetivamente do processo decisório. Tal consideração, além de apresentada por alguns entrevistados, foi constatada por esta pesquisadora, em especial, na reunião conjunta das câmaras técnicas de 30/11/2010 e na plenária de 10/12/2010. Como conseqüência, observa-se que algumas decisões são tomadas, de fato, apenas pelos membros da diretoria e coordenadores de câmaras técnicas, não por imposição, mas sim pela ausência de contribuições efetivas nas reuniões.

A vinculação do comparecimento às reuniões com os assuntos da pauta mostra que $o$ interesse dos membros se restringe a assuntos específicos, não englobando ainda os assuntos relacionados à gestão da bacia no geral, as tais "atividades construtivas", como citado por uma representante. Essa questão se mostrou mais evidente no segmento dos Municípios, do qual uma representante reconhece que "quando está todo o mundo, a discussão fica legal".

Apesar de 16 entrevistados não apontarem problemas relativos à composição atual do CBH TJ, os outros 12 representantes apresentaram várias críticas e sugestões durante as entrevistas, que podem ser separadas em 3 assuntos distintos: 
- Questões provocadas pela divergência da legislação estadual e federal de recursos hídricos, que abrangem os comitês estaduais no geral, tais como: composição tripartite, onde Estado e Município são considerados separados, e não unidos como poder público; ausência de instituições federais; e também ausência do segmento dos usuários em separado;

- Representação do segmento Municípios: obrigatoriedade de ser feita por prefeitos, inclusive na suplência, e não possibilidade de participação de todos os municípios da bacia; e

- Necessidade de revisão das vagas da Sociedade Civil devido a: ausência de representação de moradores de baixa renda, sociedades de bairros ou excluídos; mais vagas para ONGs e para a agroindústria; questionamento da participação de associações como Sociedade Civil; e das 3 vagas para universidades.

É importante citar que a vaga para representante dos usuários urbanos de água é ocupada pela Associação Nacional dos Serviços Municipais de Saneamento (ASSEMAE), representada nesta gestão pelo dirigente do Serviço Autônomo de Água e Esgotos de um dos municípios da bacia. Também as vagas das Associações de Classes e Sindicatos e das Associações Técnicas, do segmento Sociedade Civil, são usualmente preenchidas por funcionários das instituições municipais ou estaduais que atuam na bacia. Isso é visto por alguns como um desvio de representação, pois tais profissionais, em razão de seu vínculo empregatício, não têm autonomia para se pronunciar como Sociedade Civil. Neste comitê, uma profissional do IBAMA, órgão federal com atuação na região, sem direito a vaga, também já atuou desta forma, tendo inclusive ocupado a vice-presidência.

Quanto às 3 vagas destinadas às universidades, assunto também criticado durante as entrevistas, percebe-se que as mesmas universidades ocupam as cadeiras de titular e suplente dessas vagas desde a fundação do comitê, mesmo sem estar indicadas nominalmente no estatuto, como apresentado no item 7.2. Atualmente há na bacia outra universidade e também outras instituições de ensino superior atuantes, 
sendo que uma delas ocupa a vaga titular de representante dos Institutos de Pesquisas.

A questão dos limites da UGRHI serem diferentes dos limites administrativos municipais, como também dos limites das áreas regionais de órgãos estaduais, foi levantada pelos entrevistados, mesmo sem ter uma pergunta específica para tal.

Na composição atual deste comitê, alguns órgãos estaduais preenchem suas vagas de titular e suplente com profissionais de diferentes regionais atuantes na bacia. Isso, porém, não é praticado por todos os órgãos. Um dos representantes estaduais, cuja regional ocupa as duas vagas disponibilizadas para sua entidade, relatou que não se sente em condições de atuar pela bacia toda, prejudicando assim os municípios desta bacia que ficam fora de sua área de atuação. Por outro lado, alguns municípios sob sua responsabilidade fazem parte do $\mathrm{CBH}$ Mogi-Guaçu, onde ele não atua.

Conforme relatado por alguns membros, o aumento de vagas do comitê para possibilitar a participação de todos os municípios da bacia já foi proposto, amplamente discutido e não obteve aprovação da plenária. A proposta consistia no aumento para 17 vagas titulares e 17 suplentes, nos 3 segmentos, passando assim o total de membros do comitê de 36 para 51. Tal aumento possibilitaria também a participação de diferentes regionais das instituições estaduais que atuam na bacia, também solicitada por este segmento, e possibilitaria a participação de maior número de entidades da sociedade civil, hoje não representadas.

Uma característica marcante neste comitê, já comentada no item 5.6.4, é o fato da presidência ter sido ocupada por um representante da sociedade civil, e isso se deu em duas gestões seguidas. Outro ponto de destaque é a pouca rotatividade da secretaria executiva que, em sua $9^{a}$ gestão, foi 
ocupada somente por dois profissionais. Até a gestão em análise, este posto havia sido alterado apenas uma vez e, na gestão que se inicia em 2011, tal cargo voltou a ser preenchido pelo secretário que atuou nas três gestões iniciais do comitê. Uma baixa rotatividade também é notada no cargo de vice-presidente, porém com menor intensidade, visto que, até a atual gestão, apenas 4 profissionais ocuparam esta cadeira.

Ainda sobre participação, é importante colocar o depoimento de uma representante municipal:

"A população, em geral, não aprendeu ainda a participar. Acha que eleger é suficiente. Mas é dever do cidadão fazer parte também. Todos os conselhos têm participação da Sociedade Civil, são paritários, mas são sempre os mesmos que participam. O mesmo cara está em vários conselhos. Assim não evolui. O mesmo conselheiro para tudo. A sociedade tem que participar. A população tem uma parcela a cumprir nesta história toda, em todos os segmentos. É necessária mudança de cultura".

\subsubsection{Representatividade da entidade}

Ao analisar-se o tempo em que as entidades atuam neste colegiado, notase que quase metade das instituições atua há mais de 10 anos, e que muitas delas participaram da fundação do CBH TJ.

Todos os representantes reconhecem a importância da participação de sua entidade e defendem a manutenção da vaga para sua instituição. Esse fato ficou evidente em 3 representações da Sociedade Civil, onde os membros, apesar de demonstrar intenção em deixar o comitê, permanecem atuando, pois declararam ter dificuldade em indicar algum colega na entidade para substituí-los nessa atividade. Foi também relatado que, a cada renovação de gestão, há disputa pelas vagas, em especial no segmento municipal. 
Pelo estatuto dos comitês estaduais paulistas, no segmento Estado, os representantes são indicados pelas instituições detentoras de vagas conforme distribuição do estatuto do comitê e devem representar os interesses de sua instituição. No segmento Municípios, no qual as prefeituras eleitas devem representar as demais, muitos representantes municipais agem como se representassem apenas seus próprios municípios. Notou-se surpresa em alguns entrevistados ao serem questionados sobre consulta a seus pares e divulgação das decisões do comitê, o que demonstra que nem todos conhecem essa determinação do estatuto. No segmento Sociedade Civil, no qual as entidades participantes são eleitas por seus pares, isso não é tão marcante, pois elas costumam trocar informações entre seus pares no comitê, mesmo que apenas em algumas ocasiões.

\subsubsection{Representatividade do representante}

Para analisar a posição do representante em sua entidade, buscou-se conhecer os cargos que cada um ocupa. Além dos prefeitos, autoridade máxima em seus municípios, os demais representantes também ocupam cargos que mostram ter condições de se posicionar em nome das entidades que representam. Apenas 4 pessoas do segmento Estado atualmente não ocupam cargos gerenciais.

Quanto ao tempo de atuação neste comitê, $75 \%$ declararam ter começado a atuar no CBH TJ após o ano 2000. É importante ressaltar que 6 membros, representando $21 \%$ desta amostra, atuam desde a fundação deste colegiado. Dentre os 28 entrevistados, 16 membros, sendo apenas 1 do segmento Municípios, atuam ou já atuaram em câmaras técnicas, demonstrando assim um maior conhecimento das tratativas do comitê. As atividades das câmaras técnicas são de extrema 
importância neste comitê, pois, segundo comentários, "raramente a plenária modifica decisão de câmara técnica".

E todos afirmaram considerar sua participação no comitê importante para a gestão da bacia. Dentre as justificativas apresentadas para suas respostas, é interessante citar as razões que 2 membros apresentaram que os fazem participar: um membro do Estado está preocupado em direcionar melhor os parcos recursos do comitê, enquanto que um representante municipal vem ao comitê para pegar recursos para seu município e também para acompanhar análise de casos de empreendimentos em sua região. Isso mostra que a captação de recursos do FEHIDRO é um tema de grande relevância, não só para os interessados em captar recursos. A análise de EIA/RIMA de empreendimentos a serem implantados na bacia, conforme relatado no item 7.3, também desperta atenção e preocupação dos membros do comitê.

Tanto a pesquisa bibliográfica, quanto a documental, mostra que, em muitos casos, o representante se auto-representa, e não a sua instituição. Buscando avaliar o quanto isso ocorre no caso do CBH Tietê - Jacaré, foram feitas as 4 questões sobre posicionamento do representante. Os resultados mostraram que 6 membros, sendo 3 do Estado, realmente buscam representar os interesses de sua entidade, não só por meio de apoio de colegas, mas também compartilhando ideias, pois responderam positivamente às 4 questões. Dentre os demais, isto aparece com menor intensidade. A "auto-representação" parece acontecer, pelo menos, em 4 casos neste comitê, visto que 4 representantes, dos quais 2 estaduais, 1 municipal e 1 da Sociedade Civil, responderam negativamente a todas as questões. 


\subsubsection{Capacitação técnica em recursos hídricos}

Sem dúvida, trata-se de um público diferenciado, com altíssimo grau de instrução e variedade de formações, com concentração na área de engenharia. Uma parte desta formação variada, incluindo algumas não ligadas ao assunto recursos hídricos, se deve à participação dos prefeitos. Porém, boa formação não é suficiente para um bom desempenho na área de gestão das águas. Como já citado no item 5.6.7, "há que se conhecer todos os instrumentos existentes para bem utilizá-los na tomada de decisões das questões financeiras e, consequentemente, ambientais" (OLIVI, 2004, p. 71).

Com o objetivo de avaliar os conhecimentos específicos dos membros do $\mathrm{TJ}$, foram feitas perguntas sobre as Políticas Nacional e Estadual de Recursos Hídricos e seus instrumentos de gestão. Os resultados encontrados mostram que a maioria dos entrevistados conhece bem ou muito bem tais políticas, porém apenas os principais instrumentos cobrança, plano de bacia e outorga - são conhecidos pela maioria. Notouse, nesta pergunta, uma pequena confusão com instrumentos da política ambiental, e também com outros dispositivos de recursos hídricos, não instituídos como instrumentos.

\subsubsection{Informação e comunicação aos envolvidos}

Consta no estatuto do CBH TJ que todas as informações disponíveis na secretaria executiva devem ser disponibilizadas a todos os membros do comitê. Ao serem perguntados sobre o recebimento de informações relativas à implantação dos instrumentos de gestão em seu comitê, 25 entrevistados responderam positivamente. $O$ mesmo não aconteceu em relação às informações de outras bacias, mesmo as vizinhas, quando 
apenas 11 representantes declararam receber informações, 12 declararam receber poucas e 5 declararam que nunca recebem. A sugestão ouvida é que é necessário ter um mecanismo para isso.

A maioria dos entrevistados também declarou conhecer bem ou muito bem a revisão do Plano de Bacia e os critérios definidos para a implantação da cobrança pelo uso da água neste comitê.

Cabe citar aqui uma deficiência apontada por uma entrevistada sobre a ausência de um banco de dados no comitê, onde ficassem disponibilizados a todos os interessados os diversos dados, projetos $\mathrm{e}$ relatórios produzidos ou referentes à bacia.

\subsubsection{Processo de estabelecimento do Plano de Bacia}

O processo de estabelecimento da Revisão do Plano da Bacia Tietê Jacaré foi contratado junto a diversas entidades com a condição de ser desenvolvido de maneira participativa. $O$ contrato para esse trabalho recebeu recursos do FEHIDRO e foi objeto de várias reuniões plenárias e de câmaras técnicas. Por esta razão, a maioria das respostas sobre participação das entidades componentes deste colegiado se apresentou positiva.

Nota-se, porém, que o processo adotado para elaboração do Plano desagradou, principalmente, por dois motivos: foi considerado muito demorado e, mesmo assim, não apresentou o produto com a qualidade esperada pelos membros do comitê. Ao serem questionados se tal Plano demonstra os principais problemas e demandas da bacia, apenas metade das respostas foi positiva, uma foi negativa e as demais foram parciais. A consulta aos membros do comitê feita por meio de correio eletrônico para 
hierarquização das metas finais do Plano de Bacia, aprovada em plenária como descrito no item 7.4, foi considerada inadequada por alguns entrevistados, pois, segundo eles, não foram seguidas as regras de votação proporcional por segmento normalmente adotada no comitê, podendo então ter sofrido distorção por ter recebido mais respostas de um segmento mais participativo.

Apesar da proposta desta pesquisa ser a avaliação do processo participativo, e não do Plano de Bacia resultante, convém citar que, na reunião conjunta das câmaras técnicas de 30/11/2010, onde poucos presentes participaram ativamente, também ficou nítido o descontentamento de parte dos representantes presentes pelo produto apresentado, tendo sido comentado que o próprio comitê deveria desenvolver a próxima revisão deste material. $E$ ao serem questionados sobre a importância da participação das entidades do comitê na elaboração do Plano de Bacia, 13 entidades se mostraram favoráveis, 5 apenas parcialmente e uma resposta foi negativa.

\subsubsection{Processo de formulação dos critérios da cobrança}

É nítida a satisfação dos entrevistados em relação aos critérios formulados para a implantação da cobrança nesta bacia, não só pelo número de respostas positivas, mas também pelos comentários sobre a participação no processo e as oportunidades que todos tiveram para conhecer e opinar sobre eles. "O trabalho foi fantástico" comentou com entusiasmo um representante da Sociedade Civil, ao se referir às atividades do GT CA. Aproximadamente metade dos entrevistados respondeu que ele próprio ou outro representante de sua instituição participou diretamente do Grupo de Cobrança, demonstrando que a construção de tais critérios foi realmente democrática. Foram, porém, 
colocadas três questões importantes já expostas no item 7.6.8: que as pessoas em geral ainda não entenderam o que é a cobrança; que 0 consumidor final não foi ouvido; e que resta a dúvida sobre o impacto da cobrança na tarifa de água de um grande consumidor. Tais questões reforçam o questionamento sobre a composição do comitê em relação à representação dos usuários diretos.

Conforme comentários dos entrevistados, os critérios empregados atualmente para a distribuição dos recursos pelo FEHIDRO causam muitos descontentamentos, apesar do aprimoramento por ocasião da última revisão realizada em 2009 e da grande atenção que este assunto recebe por parte da maioria dos membros deste colegiado. É importante considerar que, após a implantação da cobrança, haverá um significativo acréscimo dos recursos a serem distribuídos anualmente pelo comitê, e os critérios para seleção dos projetos a serem beneficiados com tais recursos precisarão receber mais atenção por parte de seus membros.

\subsubsection{Resultado final}

O Comitê Tietê - Jacaré é visto por boa parte de seus membros como um dos mais adiantados do Estado, sendo inclusive considerado como um "comitê de vanguarda" por um membro antigo. Dentre os 28 entrevistados, 13 membros estão satisfeitos com a gestão atual da bacia, porém alguns afirmam isto tomando por base os poucos recursos financeiros e humanos disponíveis no comitê. Dentre os 9 que se declaram parcialmente satisfeitos, percebe-se a insatisfação com a morosidade na tomada de decisão e a dedicação a assuntos emergenciais, não conseguindo trabalhar nas questões mais voltadas à poluição das águas da bacia. A condução das reuniões e do comitê 
recebeu elogios de alguns membros, porém outros consideram as câmaras técnicas pouco produtivas.

Entre os motivos apresentados pelos 3 representantes que se declaram insatisfeitos, destaca-se uma situação muito citada por outros entrevistados, em diversas perguntas: "hoje o comitê é igual a um balcão". A distribuição de recursos financeiros disponibilizados pelo FEHIDRO é o principal chamariz do comitê, tanto para os interessados em obter financiamentos, quanto para os encarregados pela análise e priorização dos projetos inscritos anualmente. Muitas reuniões, tanto de câmaras técnicas, quanto plenárias, se dedicam a esse assunto. E são as reuniões onde há maior participação, pois "alguns só vão pra escolher projetos; costumam brigar por projetos". As reuniões que tratam de assuntos ligados à gestão da bacia não atraem os representantes em geral, principalmente os prefeitos. Outros motivos de insatisfação são a falta de participação do comitê nas discussões e elaboração dos planos municipais de saneamento; falta de banco de dados e projetos no comitê e ausência da agência de bacia.

A plena satisfação com o atual sistema de gestão de recursos hídricos no estado foi declarada por 11 entrevistados, sendo importante destacar duas justificativas: a importância da adoção de um sistema participativo, mesmo que moroso, pois "toda a sociedade tem oportunidade de participar"; e a experiência de "democratização de gestão pública", que demonstrou eficiência, e poderia ser expandida para outros segmentos.

Dentre os problemas apresentados pelos 14 membros que se declaram parcialmente satisfeitos, cabe destacar a desarticulação da gestão das bacias, tanto entre os municípios e o estado, especialmente quanto ao planejamento de uso do solo, como também entre as próprias secretarias estaduais; a demora para aplicação da legislação de proteção aos 
recursos hídricos; a falta da implementação efetiva da cobrança; e a falta de pessoas engajadas com tempo e disposição para fazer.

A pergunta sobre satisfação das entidades com a atual gestão de recursos hídricos no estado obteve apenas 10 respostas, sendo 6 delas positivas. Novamente foi enfatizada a importância dos comitês com sua forma democrática e tripartite. Porém, foi ressaltada a necessidade de maior ação do estado para solucionar os problemas existentes e usar a comunicação de massa para maior esclarecimento da população. A justificativa apresentada por uma das 3 pessoas parcialmente satisfeitas demonstra a necessidade do comitê reavaliar suas ações atuais em relação aos seus objetivos principais.

Um único representante respondeu negativamente às 4 perguntas deste bloco, demonstrando plena insatisfação com a gestão de recursos hídricos, tanto na bacia, quanto no estado. Sua justificativa, transcrita no item 7.6.9, demonstra também um questionamento sobre o real papel dos comitês de bacia.

Para finalizar é importante citar que, dentre os 28 membros entrevistados para essa pesquisa, representantes na gestão 2009 - 2011, 25 continuam atuando na gestão 2011 - 2013, isto é, $89 \%$ dos entrevistados. Além do vice-presidente que já ocupava este cargo, os demais ocupantes da nova mesa diretora também foram entrevistados, pois já eram membros deste comitê. A participação da nova gestão nesta pesquisa está mostrada, por segmento, na tabela 4.

Tabela 4: Participação da nova gestão na pesquisa

\begin{tabular}{cccccc}
\hline Segmentos & $\begin{array}{c}\text { Membros na } \\
\text { Plenária }\end{array}$ & $\begin{array}{c}\text { Membros entrevistados } \\
\text { Gestäo 2009 - 2011 }\end{array}$ & $\begin{array}{c}\text { Membros entrevistados } \\
\text { Gestäo 2011 - 2013 }\end{array}$ & $\%$ \\
\hline \hline Estado & 12 & 9 & 75 & 8 & 67 \\
Municípios & 12 & 9 & 75 & 7 & 58 \\
Sociedade Civil & 12 & 10 & 83 & 10 & 83 \\
\hline \hline Total & 36 & 28 & 78 & 25 & 69 \\
\hline
\end{tabular}




\section{CONCLUSÕES}

Tendo como foco a questão da participação enquanto peça fundamental na construção da gestão sustentável dos recursos hídricos, esta pesquisa, na sua primeira etapa realizou o levantamento da estrutura de gestão dos comitês de bacia do Estado de São Paulo. Durante o estudo de caso no Comitê da Bacia Hidrográfica do Tietê - Jacaré, foi feita a coleta de dados sobre a estrutura e funcionamento deste comitê e obtevese um material com significativo conteúdo sobre a realidade encontrada neste colegiado no ano de 2010, por meio da aplicação do Questionário sobre Gestão de Recursos Hídricos aos membros da plenária. Assim, em atendimento ao $1^{0}$ objetivo específico, a análise destes materiais possibilitou a identificação dos fatores-chave relacionados à participação em comitês de bacias, enquanto base organizacional, para o processo de implementação dos instrumentos de gestão, citados a seguir.

A partir da revisão de literatura e documental, esta dissertação destaca o reconhecimento da sociedade internacional e nacional da importância da participação pública de todos os envolvidos no processo de planejamento e na tomada de decisão. E, neste enfoque de gestão, apontou-se a necessidade de proporcionar condições de participação a todos os membros nas atividades do comitê, e de garantir espaço para todos os envolvidos por meio de uma composição adequada dos colegiados e de um formato eficiente de operacionalização das atividades. Assim, mostrou-se também a importância de observar a representatividade das entidades participantes do comitê, em especial nos segmentos Municípios e Sociedade Civil, nos quais as entidades são eleitas e representam sua categoria; bem como a representatividade dos representantes em relação a suas instituições, para se evitar a auto-representação, de forma a fortalecer a ideia da participação no seu sentido mais completo. 
Dois outros fatores-chave levantados foram a capacitação dos profissionais envolvidos na gestão, ressaltando aqui, entre os diversos fatores relevantes, a necessidade de conhecimentos técnicos sobre recursos hídricos; e a comunicação e troca de informações, não só da bacia onde atuam, como também das demais bacias do Estado, potencializando espaço de aprendizado e de melhoria continuada da gestão de recursos hídricos.

Quanto a esses fatores, por meio deste estudo de caso constatou-se que:

- Alguns membros do comitê enfrentam problemas práticos para se deslocar aos locais das reuniões, e muitos apresentam problemas de agenda, ocasionando, então, muitas faltas às reuniões;

- A carona para deslocamentos aos locais de reunião é praticada por muitos membros, inclusive de municípios vizinhos ou de outros segmentos, propiciando integração entre os representantes deste colegiado;

- A composição atual do comitê TJ não garante espaço a todos os envolvidos com recursos hídricos na bacia, visto que hoje a representação dos usuários urbanos é feita por dirigente municipal em nome da ASSEMAE e que não há vagas para moradores de baixa renda ou sociedades de bairros, como ocorre satisfatoriamente em outros comitês do Estado;

- Atualmente há poucas vagas para setores que deveriam ter representação mais significativa, como o de usuários, para os quais há apenas 3 vagas, ocupadas por associações, no segmento Sociedade Civil - mesmo número de vagas reservadas para as Universidades;

- Todos os representantes reconhecem a importância de suas instituições fazerem parte deste colegiado, provocando inclusive disputa por ocasião das eleições;

- Os profissionais atuantes neste comitê apresentam um alto nível de instrução, porém nem todos detêm conhecimentos sobre os instrumentos de gestão de recursos hídricos, podendo comprometer o acompanhamento dos assuntos em discussão nas reuniões do comitê; $\mathrm{e}$ 
- A comunicação e a troca de informações no âmbito do CBH TJ se dão, principalmente, pelo envio de materiais pela secretaria executiva por ocasião das reuniões, e foi considerada eficiente por seus membros.

Algumas constatações obtidas nesta pesquisa extrapolam a área de atuação desta bacia, estando, portanto, afetos à competência do Estado. São elas:

- A divisão das UGRHIs não segue os limites das bacias hidrográficas e não é adotada pelos órgãos de governo para suas divisões regionais, inclusive alguns fortemente relacionados às questões de recursos hídricos, provocando problemas para as representações de tais órgãos nos comitês;

- Pela legislação estadual, o poder público está representado por $2 / 3$ dos votos, sendo $1 / 3$ para representantes estaduais e 1/3 para municipais, acima, portanto, dos $50 \%$ estipulados pela Lei Federal no 9433/97;

- Há também divergência entre a legislação federal e a paulista quanto aos segmentos participantes dos comitês em relação à participação dos usuários no segmento Sociedade Civil, pela legislação paulista, e como segmento separado, na legislação federal;

- A divulgação de informações sobre atuação dos comitês de bacia no âmbito do Estado apresenta falhas significativas, em especial pelo site oficial do SIGRH, dificultando o conhecimento, por parte dos membros de um comitê, da realidade presente nos demais comitês paulistas.

As principais conclusões obtidas ao analisar a participação dos representantes nos processos decisórios do CBH TJ no ano de 2010, para atendimento ao $2^{\circ}$ objetivo específico desta pesquisa, são:

- Há um significativo descontentamento em relação ao número excessivo de faltas, tanto em plenárias quanto em reuniões de câmaras técnicas, sendo que parte delas acontece por baixo comprometimento de alguns representantes, ou ainda de algumas instituições; 
- A participação efetiva nas reuniões se restringe a poucos participantes, além dos membros da diretoria e dos coordenadores de câmaras técnicas, provocada provavelmente pela baixa dedicação prévia aos assuntos em discussão;

- As respostas obtidas mostraram que a presença dos membros, em especial do segmento Municípios, onde a representação é feita exclusivamente pelos próprios prefeitos, é maior em reuniões cujas pautas tratam de assuntos de interesses financeiros;

- A condução das reuniões e dos trabalhos do comitê por esta diretoria é reconhecida como eficiente por muitos entrevistados;

- A participação das entidades nas câmaras técnicas é vista como de grande importância neste comitê, uma vez que, segundo depoimentos de alguns entrevistados, suas definições são muito respeitadas pela plenária, que raramente modifica os encaminhamentos recebidos;

- Os assuntos referentes puramente à gestão da bacia ainda não conseguem atrair a atenção necessária de parte dos membros do Comitê Tietê - Jacaré;

- As atividades deste comitê giram em torno da aprovação de projetos e obtenção de financiamentos com verbas do FEHIDRO;

- Apesar de revisados recentemente, os critérios para priorização de projetos do FEHIDRO ainda recebem críticas de vários membros do comitê; e

- Atualmente este comitê tem trabalhado apenas com projetos de demanda espontânea para financiamento pelo FEHIDRO.

O 3o objetivo específico desta pesquisa, a análise da participação dos representantes dos diversos segmentos do Comitê Tietê - Jacaré nos processos decisórios relacionados à implementação dos instrumentos de gestão nesta bacia obteve dois resultados distintos para os dois instrumentos escolhidos para este estudo de caso - o Plano de Bacia e a Cobrança pelo uso da água. O processo adotado para a Revisão do Plano, elaborada por diversas entidades, contou com a participação dos membros do comitê em ocasiões específicas, atendendo à condição de participação proposta pelo próprio comitê. Esse contrato, porém, foi 
considerado muito demorado e ainda não foi encerrado oficialmente, provocando desmotivação entre os membros do comitê.

Avaliada positivamente pela maioria dos representantes, a formulação dos critérios da Cobrança foi executada por um Grupo de Trabalho formado por representantes de instituições ligadas ao comitê, sob a coordenação de um profissional membro deste colegiado. Foi um "trabalho fantástico", bem coordenado, focado e democrático, na opinião da maior parte dos representantes entrevistados.

Apesar da satisfação em relação aos resultados dessa atividade, percebe-se que o verdadeiro sentido da cobrança, como instrumento de gestão, ainda não foi entendido completamente pelo comitê e pela população em geral. Muitos a enxergam somente como uma nova fonte de recursos para financiamentos. Foi notada também a ausência de uma participação mais significativa do segmento de usuários durante os trabalhos do Grupo, visto que serão os diretamente impactados por este instrumento, reforçando assim a necessidade de análise da representatividade deste segmento na composição deste colegiado.

Ao finalizar essa pesquisa, é possível inferir que a participação dos atores envolvidos nos comitês de bacias hidrográficas tem contribuído para criar as condições necessárias para a implementação dos instrumentos de gestão de recursos hídricos no Estado de São Paulo. Tal afirmação justifica-se, pois:

- A partir da criação dos comitês de bacia, as instituições participantes do sistema passaram a dividir responsabilidades relacionadas aos recursos hídricos da bacia, incorporando profissionais de diversas formações, interesses variados e experiências diversificadas;

- O assunto água passou a ocupar novos espaços e os cuidados com os recursos hídricos passaram a ser difundidos por meios diversos; e 
- As decisões tomadas nos comitês de bacia, geralmente por consenso, são aceitas mais facilmente e dificultam, ou até mesmo inviabilizam, decisões clientelistas ou movidas apenas por interesses políticos.

Foram 28 entrevistas sobre a atuação do Comitê do Tietê - Jacaré. Vários entrevistados se mostraram apaixonados pelo tema. Com base nesses depoimentos e na experiência desta pesquisadora na participação em colegiados dos Sistemas de Gerenciamento de Recursos Hídricos, esta pesquisa aponta acertos, problemas, pontos de melhoria, e, acima disso tudo, demonstra o grande interesse e preocupação dos representantes na gestão das águas desta bacia, e a força da participação democrática nos comitês de bacia do Estado de São Paulo. 


\section{RECOMENDAÇÕES FINAIS}

O último objetivo traçado para esta pesquisa foi a identificação de pontos de melhoria do processo participativo em comitês de bacia hidrográfica visando o aprimoramento da gestão de recursos hídricos, não só da bacia estudada, como também de outras bacias hidrográficas do Estado de São Paulo.

O estatuto do comitê "estabelece que as funções de membros deste comitê não serão remuneradas" (CBH TJ, 1999, artigo 16), porém não estabelece restrição à ajuda de custo para reuniões. Visto que representantes do Estado recebem ajuda de custo para viagens e que o comitê subsidia lanches para todos, recomenda-se estudar a viabilidade de se fornecer ajuda de custo a alguns representantes da Sociedade Civil para minimizar as dificuldades enfrentadas por eles para participar das atividades do comitê. Com isso, pode-se também avaliar um aumento no total de reuniões realizadas e possibilitar, consequentemente, melhoria nos resultados do comitê. Deve-se, porém, adotar medidas para minimizar o risco de se atrair participantes que não compartilhem os objetivos e interesses da gestão das águas da bacia, como apontado no item 4.4 .

A composição atual deste colegiado recebeu críticas e sugestões de seus membros, porém também se observou que nem todos os entrevistados conheciam a composição deste comitê. Recomenda-se assim, que a composição do Comitê seja estudada internamente com atenção, não só para esclarecimentos da legislação estadual e do estatuto do comitê, como também para uma avaliação da conveniência de se alterar tal estatuto para garantir uma representação mais ampla e democrática, em especial de usuários finais urbanos. 
Outro ponto que merece atenção no estatuto deste comitê, já citado no item 7.2, é a exigência do segmento Municípios só se fazer representar pelos próprios prefeitos, realidade encontrada em poucos comitês do Estado. Face aos problemas decorrentes dessa limitação, recomenda-se a adoção de critério que possibilite que a representação municipal seja feita também por profissionais das prefeituras com atuação ligada ao tema, indicados pelos prefeitos.

Recomenda-se a instituição de regras para perda de vaga para os membros, ou mesmo para as entidades, que excederem um limite de faltas estipulado, visto que tal medida já é realidade em alguns comitês do Estado.

As críticas referentes à atual composição deste comitê, em especial quanto à participação dos usuários e à participação ser tripartite e paritária, demonstram a necessidade de se avaliar cuidadosamente as orientações da Lei Estadual ㄲo 7663/91 em relação à Lei Federal oo 9433/97. No âmbito das demais bacias do Estado, em especial às que contém também rios de domínio federal, caso das bacias vizinhas PCJ, Mogi-Guaçu e Médio Paranapanema, tais divergências ganham maiores proporções. Algumas instituições têm, ou terão em breve, participação nos colegiados estadual e federal, e convivem, ou passarão a conviver, com diferenças marcantes, inclusive, do segmento que representam, ou representarão. Tais diferenças podem provocar dificuldades significativas em sua forma de atuar em relação a conflitos e construção de pactos. Como esta constatação extrapola os limites desta UGRHI, é importante registrar a recomendação ao Conselho Estadual de Recursos Hídricos para que seja reavaliada a Lei Estadual no 7663/91, prestes a completar 20 anos de sua promulgação.

Cabe, porém, salientar a importância em se preservar um espaço específico à representação municipal, mesmo que em menor proporção 
que a estipulada na legislação paulista vigente. Pela legislação federal, a representação municipal está inserida no segmento poder público, minimizando, em alguns casos, o papel das prefeituras na gestão das águas.

Apesar da adoção da bacia hidrográfica como unidade de gestão ser um dos princípios do modelo de gestão adotado em nosso país, constata-se que os limites das UGRHIs paulistas foram determinados com base também em outros critérios. Constata-se também que vários órgãos estaduais, alguns com grande ligação às questões de recursos hídricos, adotam limites diferentes para suas divisões regionais. Recomenda-se, então, uma avaliação de tais divergências na busca da otimização da representação das instituições em cada comitê e de uma melhor atuação de seus representantes.

Um representante do segmento estadual relatou a prática periódica de sua secretaria em reunir os diversos funcionários que atuam em comitês do estado para troca de informações e experiências. Trata-se de uma atividade importante para auxiliar seus representantes a desempenhar este papel, minimizando assim os riscos de se dar a auto-representação. Cabe aqui a recomendação de se divulgar tal prática a todas as entidades que tenham diferentes regionais ou unidades para que reproduzam esta medida.

Percebe-se, pelas entrevistas, que, salvo raros casos, a participação nos comitês é uma dentre muitas atividades destes profissionais e que, em função da importância que as instituições que representam e que os próprios representantes dão a esta atividade, sua participação se dá em quantidade e qualidade variáveis. É perceptível o quanto as faltas excessivas às reuniões incomodam os próprios membros e prejudicam os resultados do comitê. É preciso que as instituições realmente reconheçam a importância deste colegiado para a gestão dos recursos hídricos na 
bacia, e da participação dos diversos profissionais nas atividades do comitê. Para isso é necessária maior divulgação das responsabilidades e das ações do comitê. Esta realidade deve também estar presente em outros comitês paulistas, e, assim sendo, recomenda-se um programa de divulgação no Estado como um todo, baseado em uma estratégia de comunicação consistente.

Também se nota que não basta o comparecimento às reuniões. A baixa participação efetiva nas reuniões, mesmo quando presentes, foi citada por vários entrevistados e percebida por esta pesquisadora. Uma de suas causas parece ser a pouca dedicação aos assuntos da bacia antes das reuniões, como apontada pelos entrevistados, como também a falta de conhecimentos específicos deste assunto. Isto é mais visível no caso dos profissionais ligados a outras áreas de atuação, e não diretamente de recursos hídricos. Nestes casos, é necessário promover palestras e eventos sobre os assuntos ligados à gestão de recursos hídricos, para melhorar a comunicação e a capacitação dos participantes das atividades do comitê, tanto aos membros da plenária como aos participantes das câmaras técnicas.

Visando melhorar o fluxo de informações e divulgação, tanto interna, quanto externamente ao comitê, uma representante municipal fez duas sugestões: implantação de um banco de dados e de projetos na sede do comitê, e a criação de um site do próprio comitê na internet, organizado e atualizado pelo comitê. Visando uma maior divulgação das atividades de todos os comitês do Estado, recomenda-se também uma reorganização e atualização do site do SIGRH.

O processo adotado por este colegiado para a formulação dos critérios da cobrança pelo uso da água contou com participação expressiva das instituições participantes deste comitê e foi amplamente elogiado. Porém, frente às críticas ouvidas sobre os critérios de distribuição de recursos 
atualmente empregados pelo Comitê, e visando evitar que os problemas apontados atualmente na distribuição de recursos se intensifiquem com a implementação da cobrança, recomenda-se uma nova revisão de tais critérios, antes que esta seja implantada por completo.

Pelos diversos comentários dos entrevistados, percebe-se a importância da sugestão de um dos membros do comitê ao dizer que "existe a necessidade de aprofundamento em relação à finalidade do comitê e efetivar ações que visem estes objetivos". Considerado por alguns como um "balcão de projetos", atualmente este comitê concentra pouca energia no desenvolvimento de assuntos ligados ao planejamento e à gestão da bacia, e muita energia nas atividades relacionadas à distribuição de verbas do FEHIDRO. Recomenda-se uma avaliação dos assuntos em andamento nas câmaras técnicas frente às atribuições do comitê para uma reprogramação de prioridades, caso esta se mostre necessária.

O tema FEHIDRO não faz parte dos objetivos desta pesquisa e, por esse motivo, não foram incluídas no questionário perguntas visando explorá-lo. Face à alta frequência de comentários pelos entrevistados, e constatada a importância deste assunto para o $\mathrm{CBH} \mathrm{TJ}$, recomenda-se que seja efetuada uma análise dos projetos priorizados para obtenção de financiamento do FEHIDRO e das solicitações não atendidas, e uma comparação com as metas priorizadas pelo Plano de Bacia. Tal ação possibilitará a fixação de diretrizes para projetos de demanda induzida, colaborando assim para que este comitê tenha uma postura pró-ativa. 


\section{REFERÊNCIAS BIBLIOGRÁFICAS}

ABRH - ASSOCIAÇÃO BRASILEIRA DE RECURSOS HÍDRICOS.

Programação do XVIII SBRH. São Paulo, 2009.

ALONSO, L. R. "Vive la France" As três leis francesas sobre a água.

Revista Brasileira de Saneamento e Meio Ambiente, jan/mar 2007, p. 15.

ALVIM, A. T. B. A contribuição do Alto Tietê à gestão da bacia metropolitana, 1994 - 2001. 2003. Tese (Doutorado em Arquitetura e Urbanismo) - FAU, USP, São Paulo.

ALVIM, A. T. B.; RONCA, J. L. C. Metodologia de avaliação qualitativa das ações dos comitês de bacias com ênfase na gestão integrada: o Comitê do Alto Tietê em São Paulo. Revista Engenharia Sanitária e Ambiental, v. 12, n. 3, jul/set 2007, p. 325-334.

AMARAL, H. K. Critérios para participação de usuários e poder público. Material didático de uso exclusivo do curso de extensão para gestores. Campinas: UNICAMP / Instituto de Economia, 1998.

ANA - AGÊNCIA NACIONAL DE ÁGUAS. A implementação da cobrança pelo uso de recursos hídricos e agência de água das bacias dos rios Piracicaba, Capivari e Jundiaí. Brasília: ANA, SAG, 2009.

ANDREU, V. Comitês de bacias fortes e atuantes são caminho para gestão compartilhada. Revista do Fórum Nacional de Comitês de Bacias Hidrográficas. Fortaleza, ano 1, n. 1, p. 7, nov. 2010.

ARCE, M. G. J. Comitês de bacias: o caminho para a proteção das nossas águas. Cadernos de Cidadania 2 - Água: Os comitês que cuidam da 
sua conservação em São Paulo. São Paulo, v. 113, n. 51, p. 3-5, mar. 2003.

ARNSTEIN, S. R. Uma escada da participação cidadã. 2009. Disponível em: <http://pt.calameo.com/read/00007359096ef6fd13b72> Acesso em: 14 mai. 2010.

ASSIS, N. M. M. V.; SALVADOR, Z. Participação e democratização da gestão de recursos hídricos: os desafios enfrentados. In: ASSIS, N. M. M. V. (Org.) Planejamento e participação: construindo o futuro juntos. São Paulo: Secretaria do Meio Ambiente, 1998. p. 85-94.

BARRAQUÉ, B. As políticas da água na Europa. Lisboa: Instituto Piaget, 1995.

BARTH, F. T. Fundamentos para gestão de recursos hídricos. In: BARTH, F. T. et al. (Org.) Modelos para gerenciamento de recursos hídricos. São Paulo: Nobel: ABRH, 1987. p. 1-91.

BARTH, F. T. Aspectos institucionais do gerenciamento de recursos hídricos. In: REBOUÇAS, A. C., BRAGA, B. e TUNDISI, J. G. (Org.) Águas doces no Brasil: capital ecológico, uso e conservação. São Paulo: Escrituras, 1999. p. 565-599.

BORGES, C. B. N. A eficiência da cobrança pelo uso da água como instrumento de gestão de recursos hídricos para as indústrias das bacias dos rios Piracicaba, Capivari e Jundiaí. 2008. Dissertação (Mestrado em Saúde Pública) - USP / FSP, São Paulo.

BORSOI, Z. M. F.; TORRES, S. D. A. A política de recursos hídricos no Brasil. Disponível em: 
$<$ http://www.bndes.gov.br/SiteBNDES/export/sites/default/bndes pt/Galeria s/Arquivos/conhecimento/revista/rev806.pdf > Acesso em: 14 dez. 2010.

BRAGA, R. Planejamento urbano e recursos hídricos. In: BRAGA, R. e CARVALHO, P. F. (Org.) Recursos hídricos e planejamento urbano e regional. Rio Claro: UNESP, 2003. p. 113-127.

BRASIL - PRESIDÊNCIA DA REPÚBLICA. Constituição da República Federativa do Brasil de 1988. Disponível em:

$<$ http://www.planalto.gov.br/ccivil 03/constituicao/constitui\%C3\%A7ao.htm > Acesso em: 14 dez. 2010.

BRASIL - PRESIDÊNCIA DA REPÚBLICA. Lei no 9433, de 8 de janeiro de 1997. Disponível em:

<http://www.planalto.gov.br/ccivil_03/LEIS/19433.htm> Acesso em: 21 ago. 2011.

BRUNA, G. C. Aspectos econômicos e sociais da utilização da água doce no ecoturismo. In: REBOUÇAS, A. C., BRAGA, B. e TUNDISI, J. G. (Org.) Águas doces no Brasil: capital ecológico, uso e conservação. São Paulo: Escrituras, 1999. p. 653-669.

CAMPOS, V. N. O. Metropolização e recursos hídricos na América Latina: O caso da Região Metropolitana de São Paulo e da Zona Metropolitana da Cidade do México. 1970 a 2000. 2001. Dissertação (Mestrado em Integração da América Latina) - USP / PROLAM, São Paulo.

CAMPOS, V. N. O. Comitê de bacia hidrográfica: um canal aberto à participação e à política? REGA - Revista de Gestão de Água da América Latina. v. 2; n. 2; p. 49-60. 2005. 
CARDOSO, M. L. M. A democracia das águas na sua prática: o caso dos comitês de bacias hidrográficas de Minas Gerais. 2003. Tese (Doutorado em Antropologia Social) - UFRJ, PPGAS, Museu Nacional, Rio de Janeiro.

CAVINI, R. Experiências internacionais de gestão de recursos hídricos: lições para a implementação da lei sobre cobrança pelo uso da água no Brasil. Disponível em:

$<$ http://www.ecoeco.org.br/conteudo/publicacoes/encontros/iii en/Mesa7/7. pdf> Acesso em: 25 mai. 2009.

CBH PCJ - COMITÊ DAS BACIAS HIDROGRÁFICAS DOS RIOS PIRACICABA, CAPIVARI E JUNDIAÍ. Uma história de amor pelas águas. Piracicaba: Modelo, 1998.

CBH PS. CBH-PS empossa nova diretoria em Taubaté. Disponível em: <http://www.comiteps.sp.gov.br/noticias-cbhps/cbh-ps-empossa-novadiretoria-em-taubate/75.html> Acesso em: 21 abr. 2011.

CBH TJ - COMITÊ DE BACIA HIDROGRÁFICA TIETÊ - JACARÉ. Estatuto. 1999. Disponível em:

$<$ http://www.sigrh.sp.gov.br/sigrh/ARQS/RELATORIO/CRH/CBHTJ/880/estatuto2.htm> Acesso em: 13 abr. 2009.

CBH TJ - COMITÊ DE BACIA HIDROGRÁFICA TIETÊ - JACARÉ. Fundamentos para cobrança pelo uso dos recursos hídricos na bacia do Tietê - Jacaré. Araraquara, 2009a. Disponível em: $<$ http://www.sigrh.sp.gov.br/sigrh/ARQS/RELATORIO/CRH/CBHTJ/1322/fundamentos\%20da\%20cobranca[0].pdf> Acesso em: 20 out. 2010. 
CBH TJ - COMITÊ DE BACIA HIDROGRÁFICA TIETÊ - JACARÉ.

Relatório de situação dos recursos hídricos na bacia do Tietê Jacaré. Araraquara, 2009b. Disponível em:

$<$ http://www.sigrh.sp.gov.br/sigrh/ARQS/RELATORIO/CRH/CBH-

TJ/1323/relatorio\%20de\%20situacao\%202009.pdf> Acesso em: 13 out. 2010.

CEPAL - Comisión Económica para América Latina y el Caribe. Recomendaciones de las reuniones internacionales sobre el agua: de Mar del Plata a París. 1998.

CESAR NETO, J. C. Política de recursos hídricos: instrumento de mudança. São Paulo: Pioneira: EDUSP, 1988.

CETESB - COMPANHIA DE TECNOLOGIA DE SANEAMENTO AMBIENTAL. Relatório de qualidade das águas interiores no Estado de São Paulo. São Paulo: CETESB, 2006.

CPTI - COOPERATIVA DE SERVIÇOS, PESQUISAS TECNOLÓGICAS E INDUSTRIAIS. Elaboração da revisão do Plano de Bacia da Unidade de Gerenciamento de Recursos Hídricos do Tietê - Jacaré (UGRHI 13): Relatório Técnico oㅡ 402/08. São Paulo: CPTI, 2008. Disponível em: $<$ http://www.ambiente.sp.gov.br/crhicomites.php> Acesso em: 09 mar. 2010.

DAEE - DEPARTAMENTO DE ÁGUAS E ENERGIA ELÉTRICA. Legislação de Recursos Hídricos: política estadual. São Paulo: 2006.

DOMINGUES, A. F. e SANTOS, J. L. Comitê de bacia hidrográfica: uma visão otimista. In: THAME, A. C. M. (Org.) Comitês de bacias hidrográficas: uma revolução conceitual. São Paulo: IQUAL, 2002. p. 6575. 
EMPINOTTI, V. Avaliação dos 20 anos do Sistema Integrado de Gerenciamento de Recursos Hídricos - SIGRH: Relatório Final, 2010. Disponível em:

$<$ http://www.sigrh.sp.gov.br/sigrh/index/informe files/RelatorioFinal 20anosSIGRH.pdf> Acesso em: 06 jan 2011.

FREITAS, I. A. S. Análise dos elementos que compõem a política de recursos hídricos. 2000. Dissertação (Mestrado em Ciências da Engenharia Ambiental) - Escola de Engenharia de São Carlos, USP, São Carlos.

GIARETTA, J. B. Z.; FERNANDES, V.; PHILIPPI JÚNIOR, A. Gestão ambiental municipal e participação nas pesquisas acadêmicas: uma análise dos estudos sobre o tema na USP. In: Encontro da ANPPAS, V, 2010, Florianópolis. Disponível em:

$<$ http://www.anppas.org.br/encontro5/cd/artigos/GT10-229-42120100828171012.pdf> Acesso em: 10 fev. 2011.

GIL, A. C. Como elaborar projetos de pesquisa? 4aㅡ ed. São Paulo: Atlas, 2002.

GODOY, A. M. G. A Conferência de Estocolmo - Evolução histórica 2. 2007. Disponível em: <http://amaliagodoy.blogspot.com/2007/09/desenvolvimentosustentvel-evoluo 16.html> Acesso em: 22 ago. 2009.

GRANZIERA, M. L. M. Direito de águas: disciplina jurídica das águas doces. São Paulo: Atlas, 2001. 
GRISOTTO, L. E. G. Análise de instrumentos de gestão de recursos hídricos. 2003. Dissertação (Mestrado em Saúde Pública) - Faculdade de Saúde Pública, Universidade de São Paulo, São Paulo.

HARMONICOP - HARMONISING COLLABORATIVE PLANNING.

Learning together to manage together : improving participation in water management. Osnabrück; 2005.

HOOPER, B. P. Key performance indicators of river basin organizations. Southern Illinois University, 2006.

HUBERT, G.; PEREIRA, J. S.; LANNA, A. E. L. Os Novos Instrumentos de Planejamento do Sistema Francês de Gestão de Recursos Hídricos: I Apresentação e Análise. RBRH - Revista Brasileira de Recursos Hídricos, v. 7; n. 2; p. 81-107, 2002.

INNES, J. E.; BOOHER, D. E. Collaborative dialogue as a policy making strategy. UCBerkeley: IURC: 2000. Disponível em: <http://escholarship.org/uc/item/8523r5zt> Acesso em: 08 abr. 2010.

JACOBI, P. R.; SINISGALLI, P. A. A.; MEDEIROS, Y.; ROMEIRO, A. R. Governança da Água no Brasil: dinâmica da política nacional e desafios para o futuro. In: JACOBI, P. R.; SINISGALLI, P. A. A. (Orgs.)

Governança da Água e Políticas Públicas na América Latina e Europa. Volume I. São Paulo: Annablume, 2009. p. 49-82.

JACOBI, P. R.; SINISGALLI, P. A. A. Apresentação. In: JACOBI, P. R.; SINISGALLI, P. A. A. (Orgs.) Governança da Água na América Latina e Europa: atores sociais, conflitos e territorialidade. Volume III. São Paulo: Annablume, 2009. p. 7-9. 
LEAL, A. C. Gestão urbana e regional em bacias hidrográficas: interfaces com o gerenciamento de recursos hídricos. In: BRAGA, R., CARVALHO, P. F. (Org.) Recursos Hídricos e Planejamento Urbano e Regional. Rio Claro: Lab. Planej. Mun. - Deplan - UNESP - IGCE, 2003. p. 65-85.

LINSLEY, R. K.; FRANZINI, J. B. Engenharia de recursos hídricos. São Paulo: McGraw-Hill do Brasil, EDUSP, 1978.

LOPES, A. A. Estudo da gestão e do gerenciamento integrado dos resíduos sólidos urbanos no município de São Carlos (SP). 2003. Dissertação (Mestrado em Ciências da Engenharia Ambiental) - Escola de Engenharia de São Carlos, USP, São Carlos.

LOPES, A. V.; FREITAS, M. A. S. A alocação de água como instrumento de gestão de recursos hídricos: experiências brasileiras. Rega - Revista de Gestão de Água da América Latina. v. 4; n.1; p. 5-28, 2007.

MACHADO, C. J. S. A Gestão Francesa de Recursos Hídricos: Descrição e Análise dos Princípios Jurídicos. RBRH - Revista Brasileira de Recursos Hídricos, v. 8; n. 4; p. 31-47. 2003.

MACHADO, J. Apresentação - Água para um planeta saudável. In: ANA AGÊNCIA NACIONAL DE ÁGUAS. A implementação da cobrança pelo uso de recursos hídricos e agência de água das bacias dos rios Piracicaba, Capivari e Jundiaí. Brasília: ANA, SAG, 2009. p. 13-16.

MACHADO, J. Mais urgência para a política de águas. Revista do Fórum Nacional de Comitês de Bacias Hidrográficas. Fortaleza, ano 1, n. 1, p. 6, nov. 2010. 
MAGALHÃES JÚNIOR, A. P. Indicadores ambientais e recursos hídricos: realidade e perspectivas para o Brasil a partir da experiência francesa. Rio de Janeiro: Bertrand Brasil, 2007.

MARIANO, M. T. Uma análise da participação da sociedade civil na gestão dos recursos hídricos no Estado de São Paulo. 1996.

Dissertação (Mestrado em Ciências da Engenharia Ambiental) - Escola de Engenharia de São Carlos, USP, São Carlos.

MATSUURA, K. A água já não flui naturalmente. Cadernos de Cidadania 2 - Água: Os comitês que cuidam da sua conservação em São Paulo. São Paulo, v. 113, n. 51, p. 6, mar. 2003.

MEDEIROS, Y. D. P.; FARIA, A. S.; GONÇALVES, M. S.; BERETTA, M.; SANTOS, M. E. Enquadramento dos corpos d'água no semi-árido brasileiro. In: JACOBI, P. R.; SINISGALLI, P. A. A. (Orgs.) Governança da água na América Latina e Europa: atores sociais, conflitos e territorialidade. Volume III. São Paulo: Annablume, 2009. p. 101-126.

MIYASHITA, H. Introdução ao gerenciamento de bacias hidrográficas no exterior e política brasileira de gestão. Material didático de uso exclusivo do curso de extensão para gestores. Campinas: UNICAMP / Instituto de Economia, 1998.

MMA - MINISTÉRIO DO MEIO AMBIENTE. Conjunto de normas legais: recursos hídricos. 6⿳亠丷a ed. Brasília: MMA, 2008a.

MMA - MINISTÉRIO DO MEIO AMBIENTE. Edição comemorativa CNRH 10 anos: recursos hídricos - uma gestão que avança. Brasília: MMA, 2008b. 
MMA - MINISTÉRIO DO MEIO AMBIENTE. Siapreh: Sistema de Acompanhamento e Avaliação da Implementação da Política de Recursos Hídricos no Brasil. Folheto. Brasília: MMA, 2008/2009.

MMA - MINISTÉRIO DO MEIO AMBIENTE. Água: manual de uso. Vamos cuidar de nossas águas implementando o Plano Nacional de Recursos Hídricos. 4ํa ed. Brasília: MMA, 2009a.

MMA - MINISTÉRIO DO MEIO AMBIENTE. Sistema Nacional de Gerenciamento de Recursos Hídricos. Disponível em:

$<$ http://www.mma.gov.br/sitio/index.php?ido=conteudo.monta\&idEstrutura $=161$ \&idConteudo=9515\&idMenu=10197> Acesso em: 28 nov. 2009b.

MMA - MINISTÉRIO DO MEIO AMBIENTE. CBH - Comitês de Bacias Hidrográficas. Bacias Estaduais. Disponível em: $<$ http://www.cbh.gov.br/\#not-estaduais > Acesso em: 20 jan. 2011.

NEDER, R. T. Avaliação da capacidade governativa de comitê de bacia hidrográfica metropolitana. FAPESP, 2000.

NORONHA, L. C. Com boa gestão, não faltará água. In: BARROS FILHO, O. L.; BOJUNGA, S. (Org.) Tempo das águas. Porto Alegre: Laser Press Comunicação, 2006. p. 15-39.

NUNES, M. R. A atuação dos Conselhos Municipais do Meio Ambiente na gestão ambiental local. 2010. Dissertação (Mestrado em Saúde Pública) - Faculdade de Saúde Pública, USP, São Paulo.

OLIVI, D. L. Análise das políticas nacional e estadual paulista de recursos hídricos. 2004. Dissertação (Mestrado em Ciências da Engenharia Ambiental) - Escola de Engenharia de São Carlos, USP, São Carlos. 
PEREIRA, A. D. A cobrança pelo uso da água: aplicação dos recursos na bacia hidrográfica de origem. 2008. Trabalho de conclusão de curso (Pós-Graduação em Direito Ambiental) - FMU, São Paulo.

PEREIRA, D. S. P. (Org.) Governabilidade dos recursos hídricos no Brasil: A implementação dos instrumentos de gestão na bacia do rio Paraíba do Sul. Brasília: ANA, 2003.

PEREIRA, D. S.; FERREIRA, R. B. Ecocidadão. Cadernos de Educação Ambiental. São Paulo: SMA / CEA, 2008.

PEREIRA, D. S. P.; JOHNSSON, R. M. F. Descentralização da gestão dos recursos hídricos em bacias nacionais no Brasil. REGA - Revista de Gestão de Água da América Latina, v. 2, n. 1, p. 53-72, 2005.

PIO, A. A água como fator crítico ao desenvolvimento sustentável. In: THAME, A. C. M. (Org.) A cobrança pelo uso da água. São Paulo: IQUAL, 2000. p. 227-235.

PIO, A. A. B. Reflexos da gestão de recursos hídricos sobre o setor industrial paulista. 2005. Dissertação (Mestrado em Engenharia) EPUSP, São Paulo.

PORTO, M. F. A.; PORTO, R. L. Gestão de bacias hidrográficas. Estudos Avançados; v. 22, n. 63, p. 43-60, 2008.

PROTA, F. G. Gestão do Esporte Universitário: as Associações Atléticas Acadêmicas na Universidade de São Paulo. 2009. Monografia, EEFE, USP, São Paulo.

RAMOS, M. Gestão de recursos hídricos e cobrança pelo uso da água. FGV / EBAP. 2007. 
REBOUÇAS, A. C. Água Doce no Mundo e no Brasil. In: REBOUÇAS, A. C., BRAGA, B. e TUNDISI, J. G. (Org.) Águas Doces no Brasil: capital ecológico, uso e conservação. São Paulo: Escrituras, 1999. p.1-37.

REZENDE, J. H. A gestão das águas e o Comitê da Bacia Hidrográfica Tietê - Jacaré completa 15 anos. 2010. Disponível em:

$<$ http://www.saocarlosoficial.com.br/noticias/?n=A+gestao+das+aguas+e+o +Comite+da+Bacia+Hidrografica+TieteJacare+completa+15+anos_HRJSM1YSSF> Acesso em: 11 jun. 11.

RIBEIRO, W. C. Geografia Política da Água. São Paulo: Annablume, 2008.

ROCHA, G. A. O sistema de gestão das águas de São Paulo. Material didático de uso exclusivo do curso de extensão para gestores. Campinas: UNICAMP / Instituto de Economia, 1998.

ROESLER, D. A.; CENCI, D. R. A participação direta dos cidadãos nas políticas socioambientais como desafio para a construção da sustentabilidade e da cidadania. In: Encontro da ANPPAS, V, 2010, Florianópolis. Disponível em: < http://www.anppas.org.br/encontro5/cd/artigos/GT10-563-81320100902163039.pdf> Acesso em: 10 fev. 2011.

SANTOS, R. Performance of River Basin Organizations in Brazil: a case study of the PCJ Committee. 2008. MSc Thesis, UNESCO-IHE Institute for Water Education, Delft.

SÃO PAULO (Estado). Poucos recursos para muita poluição. Cadernos de Cidadania 2 - Água: Os comitês que cuidam da sua conservação em São Paulo. São Paulo, v. 113, n. 51, p. 83, mar. 2003. 
SMA - SECRETARIA DO MEIO AMBIENTE DO ESTADO DE SÃO PAULO. Recursos hídricos: histórico, gestão e planejamento. São Paulo: SMA, 1995.

SMA - SECRETARIA DO MEIO AMBIENTE DO ESTADO DE SÃO PAULO. Gestão participativa das águas. São Paulo: SMA / CPLEA, 2004.

SMA - SECRETARIA DO MEIO AMBIENTE DO ESTADO DE SÃO PAULO. Guia do Sistema Paulista de Recursos Hídricos: comitês de bacias: CRH, COFEHIDRO, CORHI - São Paulo: SMA, 2008.

SMA - SECRETARIA DO MEIO AMBIENTE DO ESTADO DE SÃO PAULO. Situação dos recursos hídricos no Estado de São Paulo. Ano base 2007. São Paulo: SMA / CRHi, 2009a.

SMA - SECRETARIA DO MEIO AMBIENTE DO ESTADO DE SÃO PAULO. CBH-TJ - Representantes. Disponível em:

$<$ http://www.sigrh.sp.gov.br/cgibin/sigrh home colegiado.exe?TEMA=REPRESENTANTES\&COLEGIAD

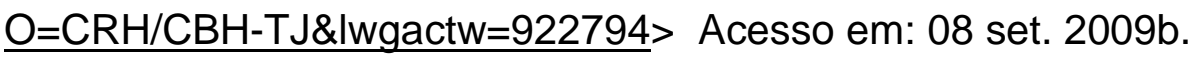

SMA - SECRETARIA DO MEIO AMBIENTE DO ESTADO DE SÃO PAULO. Panorama da cobrança no estado. 2010. Disponível em: $<$ http://www.sigrh.sp.gov.br/sigrh/cobranca/panorama.html> Acesso em: 30 out. 2010.

SMA - SECRETARIA DO MEIO AMBIENTE DO ESTADO DE SÃO PAULO. Cobrança pelo uso dos recursos hídricos. 2011. Disponível em: $<$ http://www.sigrh.sp.gov.br/cgibin/sigrh carrega.exe?f=/index/informe files/informe28cobranca5UGRHI.html> Acesso em: 30 jan. 2011. 
SOUZA, D. V. Da possibilidade à ação: novas perspectivas de gestão territorial e de atuação cidadã - o caso da APA Capivari Monos. 2007. Tese (Doutorado em Saúde Pública) - Faculdade de Saúde Pública, USP.

SOUZA, M. P. Metodologia de cobrança sobre os usos da água e sua aplicação como instrumento de gestão. 1993. Tese (Doutorado em Saúde Pública) - Faculdade de Saúde Pública, USP, São Paulo.

SOUZA, M. P. Instrumentos de gestão ambiental: fundamentos e prática. São Carlos: Editora Riani Costa, 2000.

THAME, A. C. M. Fundamentos e Antecedentes. In: THAME, A. C. M. (Org.) A cobrança pelo uso da água. São Paulo: IQUAL, 2000. p.11-16.

TUCCI, C. E. M. Modelos determinísticos. In: BARTH, F. T. et al. (Org.) Modelos para gerenciamento de recursos hídricos. São Paulo: Nobel: ABRH, 1987. p. 211-324.

TUCCI, C. E. M. Prefácio. In: TUNDISI, J. G. Água no século XXI: enfrentando a escassez. São Paulo: RiMa, IIE, 2003.

TUNDISI, J. G. Água no século XXI: enfrentando a escassez. São Paulo: RiMa, IIE, 2003.

TUNDISI, J. G.; MATSUMURA-TUNDISI, T.; PARESCHI, D. C.; LUZIA, A. P.; VON HAELING, P. H.; FROLLINI, E. H. A bacia hidrográfica do Tietê / Jacaré: estudo de caso em pesquisa e gerenciamento. Estudos Avançados; v. 22, n. 63, p. 159-172, 2008.

WATER FORUM. About Water Forum. Sacramento, 2010. Disponível em: $<$ http://www.waterforum.org/WaterConservation.cfm> Acesso em: 22 mai. 2010. 


\section{ANEXOS}

11.1 MENSAGEM ENVIADA AO SECRETÁRIO EXECUTIVO DO COMITÊ DA BACIA HIDROGRÁFICA DO TIETÊ - JACARÉ

Data: Wed, 25 Nov 2009 09:55:02 -0200 [25-11-09 09:55 09:55:02 EST]

De: mprota@usp.br@圂

Para: comitetj@ambiente.sp.gov.bra

Cc: Tadeu Fabrício Malheiros <tmalheiros@usp.br>a

Prezado Sr. Braz,

Conforme nosso contato telefônico, encaminho em anexo um resumo do projeto de pesquisa a ser apresentado à Faculdade de Saúde Pública.

Solicito sua análise e encaminhamentos necessários junto à mesa diretora do CBH TJ para aprovação do desenvolvimento da pesquisa nesta bacia.

Coloco-me à disposição para qualquer esclarecimento e informação através deste e-mail ou do telefone 1191447212.

Desde já agradeço sua atenção, Mariza

Conteúdo do arquivo enviado em anexo:

Análise do Processo Participativo na Gestão dos Recursos Hídricos no Estado de São Paulo: um Estudo de Caso do Comitê da Bacia Hidrográfica do Tietê - Jacaré

\section{Apresentação}

Trata-se de um projeto de pesquisa a ser desenvolvido para obtenção de mestrado na Faculdade de Saúde Pública da USP, junto ao Departamento de Saúde Ambiental, sob a orientação do Prof. Dr. Tadeu Fabrício Malheiros, da Escola de Engenharia de São Carlos da USP.

Sou Mariza Guimarães Prota, engenheira civil e sanitarista pela Escola Politécnica da USP, e trabalho na SABESP, desde 1986. Atualmente atuo em Câmaras Técnicas do $\mathrm{CRH}$ e do $\mathrm{CBH}$ Alto Tietê. 


\section{Introdução e Objetivos da Pesquisa}

O modelo atual de gestão dos recursos hídricos é descentralizado, participativo e integrado, tem por base a bacia hidrográfica e se baseia na atuação de comitês de bacia, que são colegiados com funções deliberativas compostos por representantes de órgãos dos diferentes níveis de governo (federal, estadual e municipal), dos usuários da água e das entidades não governamentais da sociedade civil. Cada comitê possui composição e regras de funcionamento próprias, regidas por seu estatuto.

A Política Nacional de Recursos Hídricos, instituída através da Lei 9433/97, prevê a implementação de instrumentos de gestão porém atualmente, decorridos 12 anos de sua promulgação, observam-se grandes variações no estágio de implementação destes instrumentos nas bacias hidrográficas brasileiras.

Considerando os bons resultados alcançados por alguns comitês no Brasil, a importância do processo participativo nos comitês de bacia, e a necessidade de melhoria na gestão das águas para garantia da saúde da população, esta pesquisa se propõe a analisar o impacto do processo de participação nos Comitês de Bacia Hidrográfica do Estado de São Paulo na implantação dos instrumentos de gestão.

Nossa proposta é realizar um estudo de caso no Comitê da Bacia Hidrográfica do Tietê - Jacaré - CBH TJ, por meio do qual pretende-se buscar os seguintes objetivos específicos:

- Levantar o estágio atual de implementação dos instrumentos de gestão de recursos hídricos na Bacia Hidrográfica do Tietê Jacaré em relação às bacias do Estado;

- Identificar os fatores-chave relacionados à participação para a implementação dos instrumentos de gestão;

- Levantar e analisar a participação dos representantes do Comitê da Bacia Hidrográfica do Tietê - Jacaré nos processos decisórios; e

- Identificar os avanços e dificuldades na implementação dos instrumentos neste comitê. 


\section{Metodologia e Cronograma}

Esta pesquisa deverá ser realizada em três etapas:

- Pesquisa Bibliográfica, cujo objetivo é conhecer a gestão de recursos hídricos em outros países, no Brasil e no Estado de São Paulo, por meio de sua legislação e de trabalhos sobre o tema, em especial materiais que abordem a participação dos stakeholders neste assunto e a implementação dos instrumentos de gestão. Esta etapa teve início em março de 2009 e tem final previsto para janeiro de 2010.

- Pesquisa Documental, cujo objetivo é detalhar a participação dos diversos atores na gestão de bacias hidrográficas e o estágio de implementação dos instrumentos de gestão nas bacias do Estado, por meio de pesquisas nos sites dos comitês e de consultas aos relatórios dos órgãos de recursos hídricos. Essa etapa iniciou em agosto de 2009 e deverá ser finalizada em março de 2010.

- Estudo de Caso, quando será realizado um aprofundamento da situação encontrada no CBH Tietê - Jacaré, por meio de nova pesquisa a documentos específicos deste comitê, e deverá ser aplicado um questionário a seus membros, que terá como objetivo levantar seu perfil, seu nível de conhecimento dos assuntos tratados e seu grau de comprometimento com as atividades do comitê, sua opinião sobre a participação dos diversos stakeholders neste colegiado e seu conhecimento sobre a implementação dos instrumentos de gestão nesta bacia. Essa etapa deverá ser iniciada em janeiro de 2010 e finalizada em julho do mesmo ano, sendo que a aplicação de questionários está prevista para março e abril de 2010. 


\subsection{LISTA DOS MEMBROS DO COMITÊ DA BACIA HIDROGRÁFICA DO TIETÊ - JACARÉ DA GESTÃO 2009 - 2011}

\section{Mesa Diretora:}

Presidente: Fátima Terezinha Camargo Guimarães - Prefeitura de Itaju Vice-Presidente: Jozrael Henriques Rezende - FATEC - Jaú Secretário Executivo: Braz Aureliano Biagioni Passalacqua - DAEE

\section{Representantes do Segmento Estado:}

DAEE - Titular: Braz Aureliano Biagioni Passalacqua

DAEE - Suplente: José Luiz Galvão de Mendonça

CETESB - Titular: José Jorge Guimarães

CETESB - Suplente: Marcelo Antunes Ribeiro

CBRN - Titular: Jorge Augusto de Carvalho Santos

CBRN - Suplente: Maria Eugênia de Pizzol Garcia

SABESP - Titular: Omar José Gibran

SABESP - Suplente: Ricardo Augusto Aversa

Departamento Hidroviário - Titular: Miguel Ribeiro

Secretaria da Educação - Suplente: Ana Helena Veneziani Vitor

Secretaria de Saneamento e Energia - Titular: Heitor Pelaes

Secretaria de Saneamento e Energia - Suplente: Osmar José Gualdi

Cia. Des. Agrícola de S. Paulo - Titular: Renato Soares Dinamarco Lemos

Cia. Des. Agrícola de S. Paulo - Suplente: Vanderlei Vladimir Cavichiolli

Secretaria da Agricultura - Titular: João André Miranda Almeida Prado Secretaria da Agricultura - Suplente: José Alberto Martins

Secretaria de Estado da Saúde - Titular: Márcia Cristina Cury Bassoto Secretaria de Estado da Saúde - Suplente: Eduardo Sterlino Bergo

Fundação Florestal - Titular: Amilcar Marcel de Souza

Fundação Florestal - Suplente: Honório Carlos Fachin

ERPLAN - Titular: Sérgio José Pelícola

ERPLAN - Suplente: Oraide Ap. Gonçalves Biancolli

Polícia Ambiental - Titular: 1ํTen.P.M. Leo Artur Marestoni 


\section{Representantes do Segmento Municípios:}

Titular: PM de São Carlos - Oswaldo Baptista Duarte Filho

Suplente: PM de Itirapina - Omar de Oliveira Leite

Titular: PM de Borebi - Antonio Carlos Vaca

Suplente: PM de lacanga - Ismael Edson Boiani

Titular: PM de Bauru - Rodrigo Antonio de Agostinho Mendonça

Suplente: PM de Areiópolis - José Pio de Oliveira

Titular: PM de Jaú - Osvaldo Franceschi Júnior

Suplente: PM de Lençóis Paulista - Izabel Cristina Campanari Lorenzetti

Titular: PM de Trabiju - Maurílio Tavoni Junior

Suplente: PM de Dourado - Edmur Pereira Buzza

Titular: PM de Bocaina - João Francisco Bertoncello Danieletto

Suplente: PM de Itapuí - José Gilberto Saggioro

Titular: PM de Nova Europa - Walter Willian Figueiredo

Suplente: PM de São Manoel - Tharcílio Baroni Júnior

Titular: PM de Itaju - Fátima Terezinha de Camargo Guimarães Suplente: PM de Agudos - Everton Octaviani

Titular: PM de Boa Esperança do Sul - Jaime Fortino Benassi

Suplente: PM de Gavião Peixoto - Ronivaldo Sampaio Fratuci

Titular: PM de Pederneiras - Ivana Maria Bertoline Camarinha

Suplente: PM de Macatuba - Coolidge Hercos Júnior

Titular: PM de Igaraçu do Tietê - Carlos Augusto Gama

Suplente: PM de Boraceia - Osvaldo Gianti

Titular: PM de Bariri - Benedito Senafonde Mazotti

Suplente: PM de Dois Córregos - Luis Antonio Nais

\section{Representantes do Segmento Sociedade Civil:}

Titular: ASSEMAE - São Carlos - Eduardo Antonio Teixeira Cotrim

Suplente: ASSEMAE - Bauru - Ivan Alexandre Ferrazoli de Marche

Titular: UNICA - Rudinei Sérgio Pestana

Suplente: UDOP - Denis Lucas da Silva 
Titular: CIESP - Araraquara - José Ricardo de Lima

Suplente: CIESP - Bauru - Caio César Passianoto

Titular: USP - São Carlos - João Luiz Boccia Brandão

Suplente: USP - São Carlos - Edson Cezar Wendland

Titular: UFSCar - Nemésio Neves Batista Salvador

Suplente: UFSCar - Maria da Graça Gama Melão

Titular: UNESP - Araraquara - Adalberto Farache Filho

Suplente: UNESP - Araraquara - Miguel Jafelicci Júnior

Titular: FATEC - Jaú - Jozrael Henriques Rezende

Suplente: Instituto Ambiental Vidágua - Katarini Giroldo Miguel

Titular: Verde e Vida - José Aparecido Garzin

Suplente: Aresalva Tietê - João Carlos de Souza

Titular: Fórum Pró-Batalha - Eliel Oioli Pacheco Júnior

Suplente: Instituto Pro-Terra - Jaú - Yanina Micaela Sammarco

Titular: SEESP - Araraquara - Rogério do Prado Lima

Supl.: OAB - Barra Bonita e Igaraçu do Tietê - Maria Elizabeth Ribeiro

Titular: ABES - Bauru - Gilberto Sebastião Castilho Filho

Supl.: APG - Assoc. Paulista de Geólogos - João Paulo Fonseca Correia

Titular: Mãe Natureza - Barra Bonita - Hélio Palmesan

Suplente: Mãe Natureza - Gisele Mondoni Marconato

Fonte: SMA, 2009b

Nota: foram feitas alterações com informações fornecidas pelo secretário executivo e pelos representantes 


\title{
11.3 APRESENTAÇÃO DA PESQUISA AOS ENTREVISTADOS
}

\author{
Análise do Processo Participativo na Gestão dos Recursos Hídricos \\ no Estado de São Paulo: um Estudo de Caso do Comitê da Bacia \\ Hidrográfica do Tietê - Jacaré
}

\section{Apresentação}

Trata-se de um projeto de pesquisa a ser desenvolvido para obtenção de mestrado na Faculdade de Saúde Pública da USP, junto ao Departamento de Saúde Ambiental, sob a orientação do Prof. Dr. Tadeu Fabrício Malheiros, da Escola de Engenharia de São Carlos da USP.

Sou Mariza Guimarães Prota, engenheira civil e sanitarista pela Escola Politécnica da USP, e trabalho na SABESP, desde 1986. Atualmente atuo em Câmaras Técnicas do CRH e do CBH Alto Tietê.

\section{Introdução e Objetivos da Pesquisa}

O modelo atual de gestão dos recursos hídricos é descentralizado, participativo e integrado, tem por base a bacia hidrográfica e se baseia na atuação de comitês de bacia, que são colegiados com funções deliberativas compostos por representantes de órgãos dos diferentes níveis de governo (federal, estadual e municipal), dos usuários da água e das entidades não governamentais da sociedade civil. Cada comitê possui composição e regras de funcionamento próprias, regidas por seu estatuto.

A Política Nacional de Recursos Hídricos, instituída através da Lei 9433/97, prevê a implementação de instrumentos de gestão, porém atualmente, decorridos 12 anos de sua promulgação, observam-se grandes variações no estágio de implementação destes instrumentos nas bacias hidrográficas brasileiras. 
Considerando os bons resultados alcançados por alguns comitês no Brasil, a importância do processo participativo nos comitês de bacia, e a necessidade de melhoria na gestão das águas para garantia da saúde da população, esta pesquisa se propõe a analisar o processo de participação em comitês de bacia hidrográfica do Estado de São Paulo na implementação de instrumentos de gestão na bacia.

Nossa proposta é realizar um estudo de caso no Comitê da Bacia Hidrográfica do Tietê - Jacaré - CBH TJ, por meio do qual pretende-se buscar os seguintes objetivos específicos:

- Identificar os fatores-chave relacionados à participação em comitês de bacia hidrográfica para o processo de implementação dos instrumentos de gestão;

- Levantar o estágio atual de implementação dos instrumentos de gestão de recursos hídricos na Bacia Hidrográfica do Tietê Jacaré em relação às bacias do Estado;

- Levantar e analisar a participação dos representantes do Comitê da Bacia Hidrográfica do Tietê - Jacaré nos processos decisórios; e

- Identificar a contribuição da participação dos diversos atores à aprovação do Plano da Bacia e à elaboração dos critérios da cobrança pelo uso dos recursos hídricos.

\section{Metodologia e Cronograma}

Esta pesquisa deverá ser realizada em três etapas:

- Pesquisa Bibliográfica, cujo objetivo é conhecer a gestão de recursos hídricos em outros países, no Brasil e no Estado de São Paulo, por meio de sua legislação e de trabalhos sobre o tema, em especial materiais que abordem a participação dos stakeholders neste assunto e a implementação dos instrumentos de gestão. 
Esta etapa teve início em março de 2009 e tem final previsto para julho de 2010.

- Pesquisa Documental, cujo objetivo é detalhar a participação dos diversos atores na gestão de bacias hidrográficas e o estágio de implementação dos instrumentos de gestão nas bacias do Estado, por meio de pesquisas nos sites dos comitês e de consultas aos relatórios dos órgãos de recursos hídricos. Essa etapa iniciou em agosto de 2009 e deverá ser finalizada em julho de 2010.

- Estudo de Caso, quando será realizado um aprofundamento da situação encontrada no CBH Tietê - Jacaré, por meio de nova pesquisa a documentos específicos deste comitê, e deverá ser aplicado um questionário a seus membros, que terá como objetivo levantar seu perfil, seu nível de conhecimento dos assuntos tratados e seu grau de comprometimento com as atividades do comitê, sua opinião sobre a participação dos diversos stakeholders neste colegiado e seu conhecimento sobre a implementação dos instrumentos de gestão nesta bacia. Essa etapa iniciou em janeiro de 2010 e deverá ser finalizada em agosto do mesmo ano, sendo que a aplicação de questionários está prevista para junho e julho de 2010.

São Paulo, 31 de maio de 2010

Contato: cel. (11) 91447212 ou mprota@usp.br. 


\subsection{TERMO DE CONSENTIMENTO}

Como membro do Comitê da Bacia Hidrográfica do Tietê - Jacaré, aceito participar da pesquisa acadêmica intitulada Análise do Processo Participativo na Gestão dos Recursos Hídricos no Estado de São Paulo: um Estudo de Caso do Comitê da Bacia Hidrográfica do Tietê - Jacaré, que está sendo realizada pela pesquisadora Mariza Guimarães Prota, sob a orientação do Prof. Dr. Tadeu Fabrício Malheiros, no programa de Mestrado da Faculdade de Saúde Pública da USP.

Sei da importância da participação dos membros deste comitê, pois a bacia Tietê - Jacaré foi escolhida como estudo de caso, e concordo em responder ao questionário elaborado com o objetivo de levantar o perfil dos membros do comitê, nossa opinião sobre a gestão dos recursos hídricos e a participação dos diversos segmentos neste colegiado e nosso conhecimento sobre a implementação dos instrumentos de gestão. Fui informado que as informações individuais são confidenciais, os dados serão utilizados somente em caráter acadêmico e que as conclusões obtidas nesta pesquisa serão apresentadas ao Comitê Tietê - Jacaré.

Assim eu,

aceito participar deste projeto, ciente de que será mantido sigilo sobre minha identidade, autorizo a utilização dos dados obtidos nesta pesquisa para fins acadêmicos e para a publicação em revistas especializadas e congressos. Sei que minha participação é voluntária, que minha recusa em participar não irá acarretar qualquer penalidade e que, em caso de dúvidas, poderei contatar a pesquisadora, através dos telefones (11) 3842 0386 / (11) 91447212 ou do e-mail mprota@usp.br ou o Comitê de Ética em Pesquisa da Faculdade de Saúde Pública da USP, sito à Av. Dr. Arnaldo, 715, Cerqueira César - São Paulo, SP, telefone (11) 30617779.

Local e data

Assinatura do Participante 


\subsection{QUESTIONÁRIO SOBRE GESTÃO DE RECURSOS HÍDRICOS}

Essas informações serão utilizadas exclusivamente para fins da pesquisa acadêmica Análise do Processo Participativo na Gestão dos Recursos Hídricos no Estado de São Paulo: um Estudo de Caso do Comitê da Bacia Hidrográfica do Tietê - Jacaré e serão tratadas sigilosamente.

Sua participação, como membro deste comitê, é de extrema importância para o sucesso desta pesquisa.

Estou à disposição através dos telefones (11) 91447212 ou do e.mail mprota@usp.br para quaisquer dúvidas ou comentários.

1. Informações sobre o representante do $\mathrm{CBH} \mathrm{TJ}$ :

1.1 Nome:

1.2 Entidade que representa:

1.3 Profissão / Formação:

1.4 Cargo do representante na entidade:

1.5 Endereço da entidade / CEP:

1.6 Cidade da entidade que representa:

1.7 Telefones para contato:

1.8 E-mail para contato:

1.9 Cidade em que reside:

1.10 Idade:

1.11 Escolaridade:

1.12: Sexo:

2. Informações sobre a entidade que representa e sua atuação no comitê: 
2.1 A vaga de sua entidade no comitê é garantida pelo estatuto ou é obtida por meio de eleição entre outras entidades do mesmo segmento? 2.2 Há quanto tempo sua entidade está representada neste comitê - na plenária e em câmaras técnicas?

2.3 Há quanto tempo você participa do comitê?

2.4 Antes de atuar como membro na plenária, você já atuou em alguma câmara técnica?

2.5 Você recebe apoio técnico de outras pessoas de sua entidade para sua atuação no comitê?

2.6 Você costuma compartilhar os assuntos discutidos no comitê com outras pessoas de sua entidade?

2.7 Você costuma buscar as opiniões dos colegas e/ou superiores para levar ao comitê?

2.8 Você costuma levantar as reinvidicações de sua entidade para levar ao comitê?

2.9 No caso de entidade que representa uma categoria: Você costuma buscar a opinião e/ou as reinvidicações das demais entidades do seu setor para levar ao comitê?

2.10 No caso de entidade que representa uma categoria: Você costuma divulgar as decisões do comitê a essas entidades?

2.11 Você recebe alguma ajuda financeira para comparecer às reuniões? Especificar quais: transporte, alimentação, diária.

2.12 Você está satisfeito com suas condições de participação no comitê?

2.13 Você considera que sua participação é importante para a gestão da bacia?

2.14 Você considera que a participação de sua entidade é importante para a gestão da bacia?

2.15 Você vê algum problema na participação de algum segmento específico na gestão da bacia? Citar o tipo de problema e o segmento. (Ex.: faltas sucessivas de algum setor, pouca participação efetiva em reuniões) 
2.16 Você vê algum problema na composição do comitê, quanto ao número de vagas e/ou quanto às entidades participantes?

3. Informações gerais sobre a gestão de recursos hídricos:

3.1 Você conhece a Política Nacional de Recursos Hídricos? Assinalar:

$\begin{array}{llll}\text { ( ) Muito bem } & \text { ( ) Bem } & \text { ( ) Superficialmente } & \text { ( ) Não }\end{array}$ conheço

3.2 Você conhece a Política Estadual de Recursos Hídricos? Assinalar:
( ) Muito bem
( ) Bem
( ) Superficialmente
( ) Não conheço

3.3 Citar os instrumentos de gestão de recursos hídricos que você conhece:

4. Suas impressões sobre a gestão atual da Bacia do Tietê - Jacaré:

4.1 Você recebe informações sobre o andamento da implantação dos instrumentos de gestão na sua bacia?

4.2 Você conhece o Plano da Bacia do Tietê - Jacaré?

4.3 Você considera que este plano demonstra os principais problemas e demandas da bacia?

4.4 Sua entidade participou da elaboração desse plano?

4.5 As demais entidades do comitê participaram da elaboração do plano?

4.6 Você considera que a participação dos diversos segmentos foi importante para a qualidade do Plano de Bacia?

4.7 Você conhece os critérios definidos pelo Comitê Tietê - Jacaré para a cobrança pelo uso dos recursos hídricos?

4.8 Sua entidade está satisfeita com os critérios formulados?

4.9 Você, ou outro representante de sua entidade, participou do GT Cobrança?

4.10 Você considera que a participação dos diversos segmentos neste processo foi significativa? 
4.11 Você está satisfeito com a gestão atual dos recursos hídricos desta bacia? Justifique sua resposta.

4.12 Sua entidade também está satisfeita? Justifique sua resposta.

5. Suas impressões sobre a gestão atual dos recursos hídricos do Estado de São Paulo:

5.1 Você tem informações sobre $o$ andamento das atividades dos demais comitês do Estado?

5.2 Você está satisfeito com a gestão de recursos hídricos no Estado? Justifique sua resposta.

5.3 Sua entidade também está satisfeita? Justifique sua resposta.

6. Suas considerações finais sobre o CBH Tietê - Jacaré ou em geral.

Favor enviar o questionário preenchido para mprota@usp.br.

Muito obrigada pela sua colaboração!

Mariza Guimarães Prota 


\subsection{TERMO DE RESPONSABILIDADE}

Eu, Mariza Guimarães Prota, como pesquisadora responsável pela pesquisa para dissertação de mestrado intitulada Análise do Processo Participativo na Gestão dos Recursos Hídricos no Estado de São Paulo: um Estudo de Caso do Comitê da Bacia Hidrográfica do Tietê - Jacaré comprometo-me a assegurar o anonimato e o sigilo das respostas ao questionário aplicado aos membros do comitê, zelar pela integridade das informações prestadas, bem como devolver ao CBH TJ os resultados obtidos ao final da pesquisa.

Coloco-me à disposição para qualquer esclarecimento ou informação adicional, através dos contatos:

e-mail: mprota@usp.br

telefone: 1191447212.

São Paulo, 14 de dezembro de 2009

Mariza Guimarães Prota 


\subsection{CURRICULUM DA PESQUISADORA}

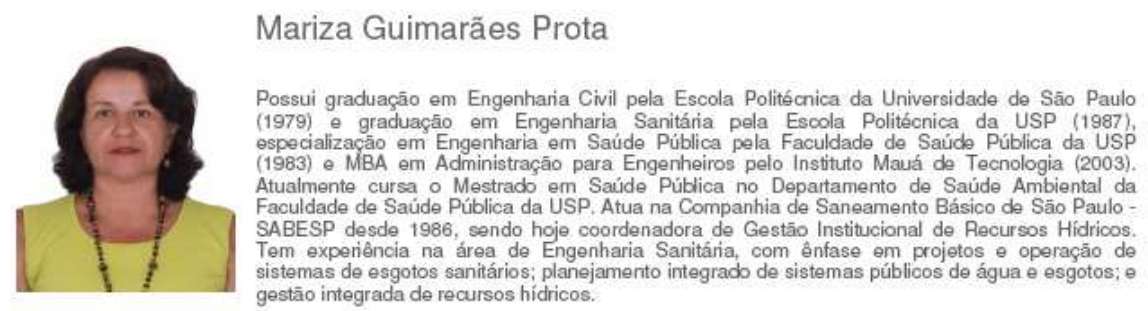

(Tex to informado pelo autor)

Última atua lizaçăo em 04/07/2011

Endereço para acessar este CV:

http://lattes.onpq.br/4792601746314141

\begin{tabular}{|c|c|}
\hline Dados Pessoais & \\
\hline Nome & Mariza Guimarāes Prota \\
\hline $\begin{array}{r}\text { Nome em citaçōes } \\
\text { bibliográficas }\end{array}$ & PROTA, M. G. \\
\hline Sexo & feminino \\
\hline Filliaçāo & Luiz José Guimarāes Barros e Célia Sikva Guimarāes Barros \\
\hline Nascimento & 20/03/1956 - Bauru/SP - Brasil \\
\hline Carteira de Identidade & 6599169 SSP - SP - 08/07/1982 \\
\hline CPF & 03230003802 \\
\hline Endereço residencial & $\begin{array}{l}\text { Rua Dr. Sodré, } 158 \text { apto } 22 \mathrm{~L} \\
\text { Vila Olimpia - Sao Paulo } \\
\text { 04535-110, SP-Brasil } \\
\text { Telefone: } 11 \text { 38420386 } \\
\text { URL da home page: mprota@ajato.com.br }\end{array}$ \\
\hline Endereço profissional & $\begin{array}{l}\text { Cia de Saneamento Básico do Estado de São Paulo - Pinheiros, Depto de Gestão de Recursos Hídricos } \\
\text { Rua Costa Carvalho, } 300 \\
\text { Pinheiros - Sao Paulo } \\
05429-900, \text { SP-Brasil } \\
\text { Telefone: } 11 \text { 33889524 } \\
\text { URL da home page: mprota@sabesp.com.br }\end{array}$ \\
\hline Endereço eletrônico & $\begin{array}{l}\text { e-mail para contato : mprota@ajato.com.br } \\
\text { e-mail alternativo : mprota@sabesp.com.br }\end{array}$ \\
\hline
\end{tabular}

Formação Acadèmica/Titulaçăo

2009 Mestrado em Saúde Pública.

Faculdade de Sande Pública da USP FSP / USP, Brast

Título: Análise do processo participativo na gestão dos recursos hídricos no Estado de São Paulo: um estudo de caso do Comitê da Bacia Hidrográfica do Tietê - Jacaré

Orientador: Tadeu Fabricio Malheiros

Palavras-chave: Gestâo de Recursos Hídricos, Comitê de Bacia Hidrográfica, Processo Participativo, Bacia do TietêÁreas do conhecimento: GESTAODE RECURSOS HIDRICOS

2003 - 2003 Especialização em MBA em Administração para Engenheiros.

Instituto Maua de Tecnologia, IMT, Sao Paulo, Brasi

Título: "Ólho Vivo" - Diagnóstico e Manutenção de Instalaçōes Hidráulicas Prediais - Plano de Empreendimento

Orientador: Bernardo Leite Moreira

1983 - 1983 Especialização em Engenharia em Saúde Pública

Faculdade de Saudo Publica da Univergidade de São Paulo, FSP-USP, Brasil

Título: Controle de Odores em Sistemas de Esgotos

Orientador: Antonio Carlos Rossin

1984 - 1987 Graduaçâo em Engenharia Sanitária

Escola Politecnica da Universidade de Sâo Paulo, EPUSP, Brasil 


\subsection{CURRICULUM DO ORIENTADOR}

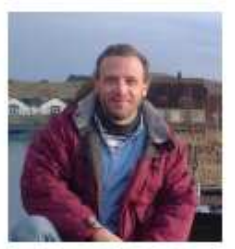

Tadeu Fabricio Malheiros

Possui graduaçăo em Engenharia Civil pela Universidade de Săo Paulo (1991), especializacăo em engenharia ambiental (1003) mestrado em Pesources Engineering Universitat Karlsruhe (1996) doutorado em Saúde Pública pela Universidade de Săo Paulo (2002), pós-doutorado en Saúde Pública pela Faculdade de Saúde Pública - USP (2006). Atualmente é professor doutor na Escola de Engenharia de Săo Carlos da Universidade de São Paulo e vice-coordenador do Programa de Pós Graduaçăo em Ciências da Engenharia Ambiental. Tem expenencia na area de Engenharia Ambiental, com entase em Saude Ambiental, atuando principalmente nos seguintes temas: indicadores de sustentabilidade, desenvolvimento sustentável, meio ambiente, saúde pública, residuos sólidos e gestão ambiental

(Texto informado pelo autor)

Ûtima atualizaçấo do curriculo em 25/08/2009

Endereço para acessar este CV:

http://lattes. cnpq. br/4422237568128846

Dados pessoais

Nome Tadeu Fabricio Malheiros

Nome em citacōes MALHEIROS, Tadeu Fabricio

blbllográficas

Sexo Masculino

Endereço profissional Universidade de Săo Paulo, Escola de Engenharia de São Carlos, Departamento de Hidráulica $\theta$ Saneamento. Avenida São Carlense 400

Avenido

13566-590 - Sao Carlos, SP - Brasil - Caixa-Postal: 359

Telefone: (16) 33739530

URL da Homepage: htto:/ hww fsp. usp. brisiades

Formação acadêmica/Titulação

2004-2006 Pós-Doutorado

Universidade de São Paulo, USP, Brast.

Bosista dola). Coordenaça de Aperfeiçcamento de Pessoal de Nivel Superior.

Grande area: Engenharias / Ares. Engenharia Sanitánia/ Suberea Saneamento Ambienta

Grande área: Engenharias / Areas Engenharia Sanitária / Subrear Planejamento Ambiental / Especialidade: Indicadores

1997 - 2002 Doutorado em Saúde Pública (Conceito CAPES 5).

Título: Indicadores Ambientais de Desenvolvimento Sustentável Local: um estudo de caso do uso de indicadores da qualidade do ar, Ano de Obtençàa: 2002

Palavras-chave: Poluiçao do Ar; desenvolvimento sustentável; indicadores de sustentabilidade.

Grande área: Engenharias / Árear Engenharia Sanitária / Subérex Planejamento Ambiental.

Grande área: Engenharias / Arear Engenharia Sanitária

Setores de atividade: Deservolvimento Urbano.

1994 - 1996 Mestrado em Resources Engineering.

Universitat Karlsruhe, U.F.K., Alemanha.

Titulo: Guideline for

Bdrista do (a): Deutschland Akademisches Austauschdienst, .

Palavres-chave: Sustainable development; Small town; Cambui- MG.

Grande área: Engenharias / Area: Engenharia Sanitária.

Setores de atividade: Deservolvimento Untano.

1993 - 1993 Especializaçăo em Engenharia em Saúde Pública e Ambiental, (Carga Horária: 985h). Universidade de Sảo Paulo, USP, Brast

Titulo: Trabalho de Campo Multidisciplinar em tha Bela

1985 - 1991 Graduaçăo em Engenharia Civil

Universidade de Săo Paulo, USP, Brasil. 
Análise do processo participativo na gestão dos recursos hídricos no Estado de São Paulo: um estudo de caso do Comitê da Bacia Hidrográfica do Tietê - Jacaré

Aluna: Mariza Guimarães Prota Orientador. Prof. Dr. Tadeu Fabrício Malheiros

\section{Índice}

- Introdução e Justificativa da Pesquisa

- Objetivos da Pesquisa

- Metodologia

- Gestão de Recursos Hídricos

- Gestão de Recursos Hídricos no Brasil

- Categorias para a Análise do Processo Participativo

- Estudo de Caso do Comitê da Bacia Tietê - Jacaré

- Conclusões

- Recomendações Finais 


\section{Gestão das Águas no Brasil}

- Lei 9433/97 - Política Nacional de Recursos Hídricos:

- Água como recurso econômico

- Gestão integrada dos usos múltiplos da água

- Modelo descentralizado e participativo

- Bacia hidrográfica como unidade de gestão

- Constituição de comitês de bacia

- Instrumentos de gestão

\section{Gestão das Águas em São Paulo}

- Lei 7663/91 - Política Estadual de Recursos Hídricos:

= Descentralização,Participação e Integração

- Comitês de Bacia com autonomia para decisão

= Implementação de instrumentos de gestão 


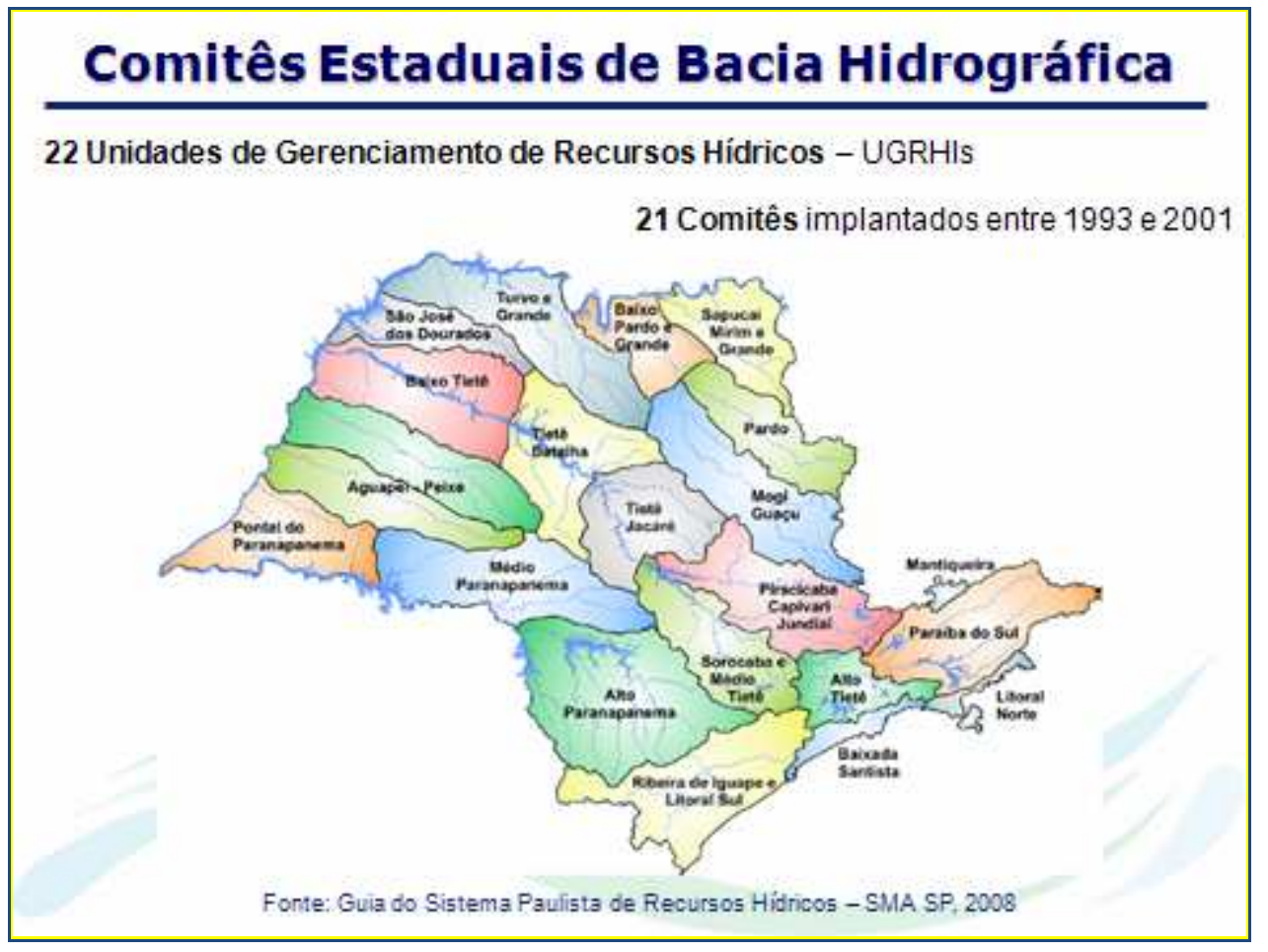

\section{Situação Atual dos Comitês}

Existência de legislação adequada não é suficiente para garantir qualidade e quantidade de água necessárias

$\rightarrow$ Diferentes estágios de implementação dos instrumentos de gestão

$\rightarrow$ Poucos instrumentos de gestão implantados em algumas bacias 


\section{Perguntas da Pesquisa}

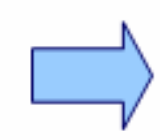

A participação dos atores envolvidos nos comitês de bacias contribui para a implementação dos instrumentos de gestão numa bacia hidrográfica?

- Qual é a estrutura de gestão dos comitês de bacia do Estado de São Paulo?

- Como se dá a participação dos diversos atores nos processos decisórios nos comitês de bacias hidrográficas?

- Como é a participação dos diversos segmentos nos processos relacionados à implantação dos instrumentos de gestão nos comitês de bacia?

- Quais ações podem ser feitas, quanto à participação dos membros, para aprimorar as atividades dos comitês?

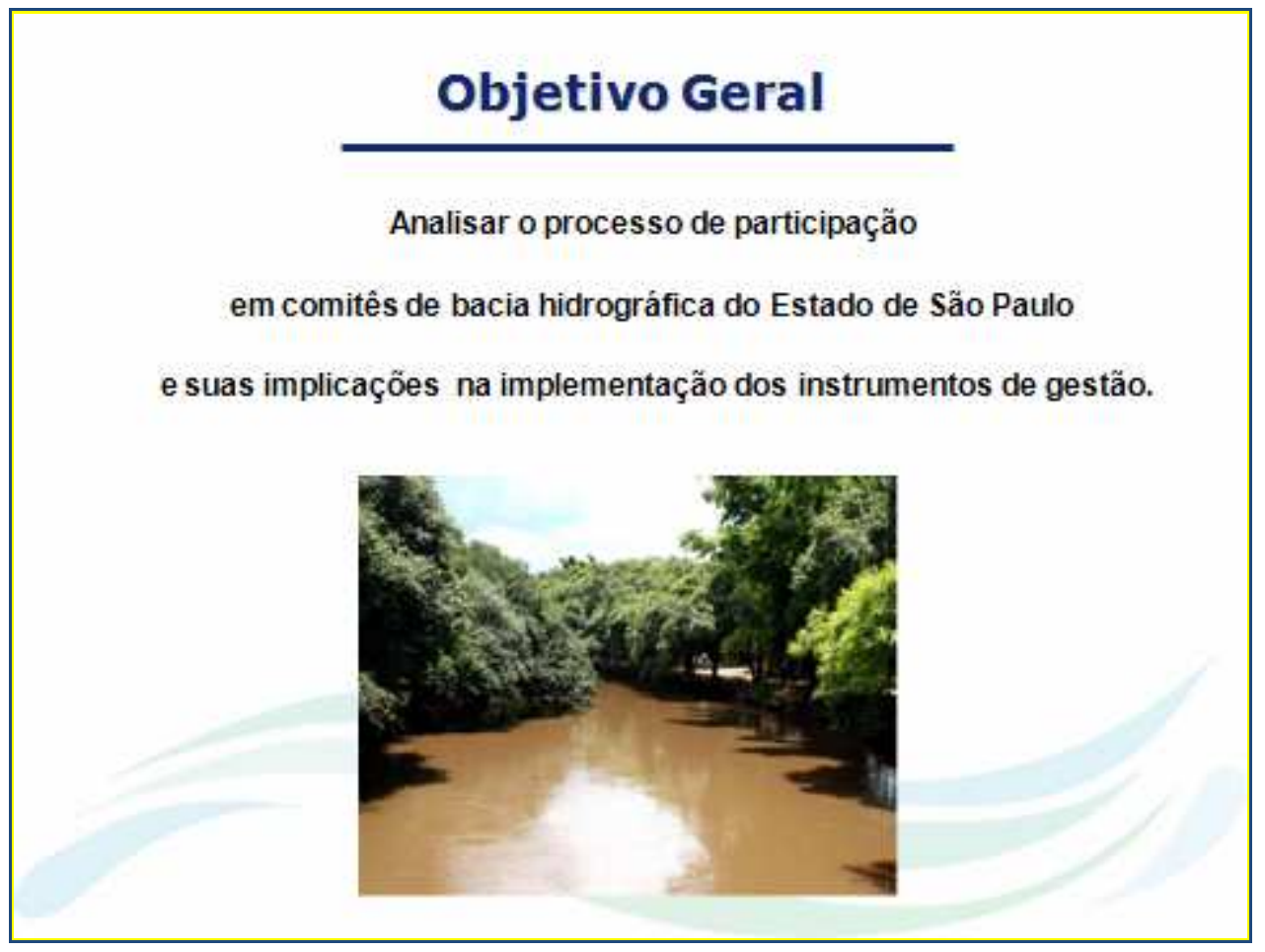




\section{Objetivos Específicos}

- Identificar os fatores-chave relacionados à participação em comitês de bacias para a implementação dos instrumentos de gestão;

- Levantar e analisar a participação dos representantes do Comitê da Bacia Hidrográfica do Tietê-Jacaré:

- Analisar a participação dos segmentos do Comitê Tietê-Jacaré nos processos decisórios relacionados à implementação dos instrumentos de gestão;e

- Identificar pontos de melhoria do processo partidpativo em comitês de bacia para aprimoramento da gestão de recursos hídricos.

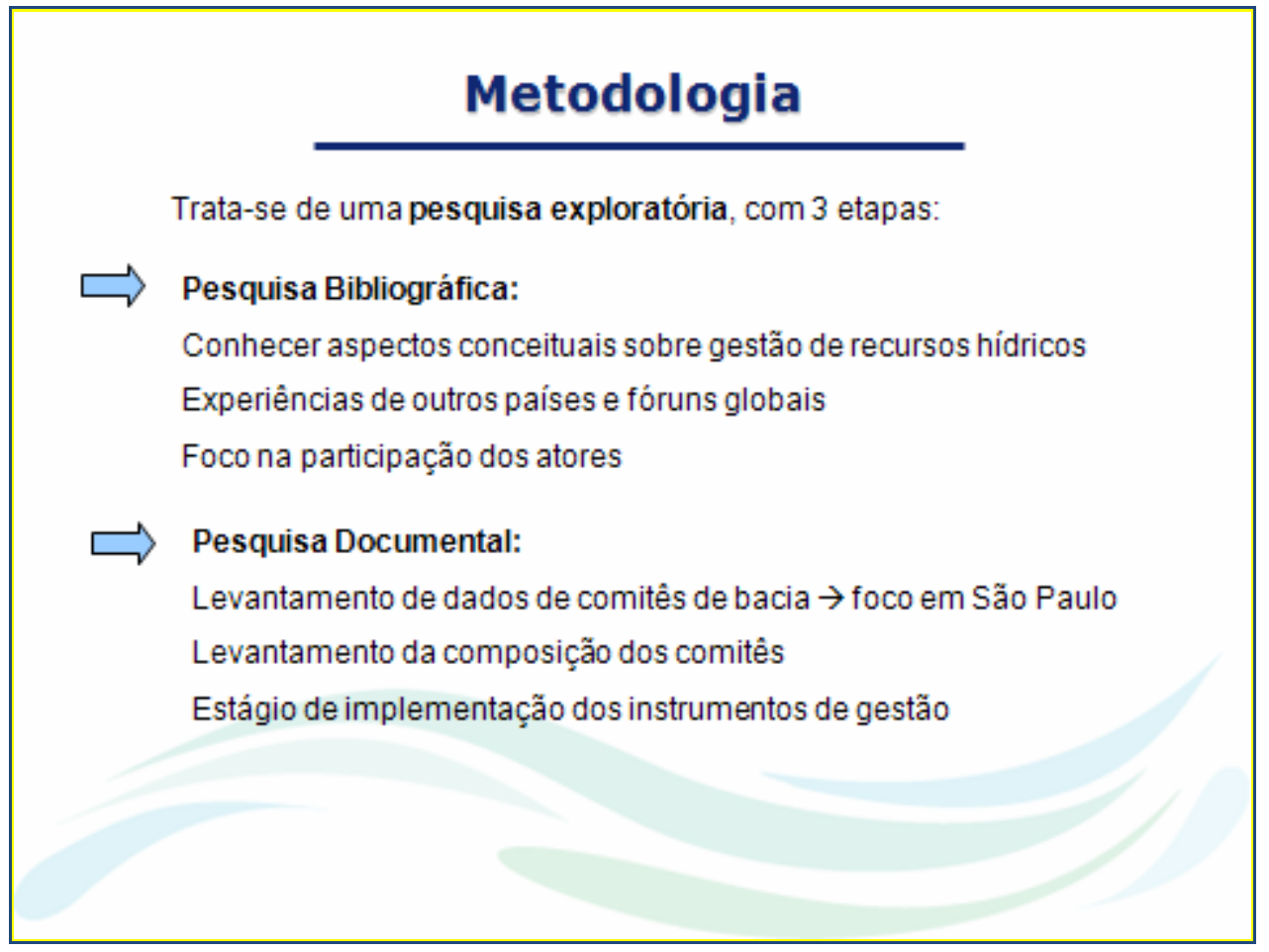




\section{Metodologia}

Estudo de Caso no Comitê da Bacia do Tietê - Jacaré:

Aprofundamento na pesquisa documental

Aplicação de questionários aos membros do CBH TJ - gestão 2009 - 2011

=Foco no processo participativo

= Instrumentos de gestão: Plano de Bacia e Cobrança

=Atividades sob responsabilidade do comitê

Análise dos resultados dos questionários e dos demais materiais coletados,

com base nas categorias de análise

- Comitê de Ética $\rightarrow$ garantia de sigilo aos participantes

\section{Gestão de Recursos Hídricos}

- Aspectos conceituais

- Fóruns globais sobre água e meio ambiente

- Experiências internacionais

- França

- Alemanha

- Estados Unidos

- Aspectos sobre participação social

10 Lições da Experiência Internacional 


\section{Lições da Experiência Internacional}

1. Reconhecimento da água como um bem precioso, de valor inestimável, e fundamental às atividades humanas e ao

desenvolvimento sócio-econômico;

2. Necessidade de formulação de políticas nacionais de água, estabelecendo arranjos institucionais nas diversas esferas com o comprometimento dos governos;

3. Sugestão da adoção da bacia hidrográfica como unidade de gestão;

4. Instituição de um comitê para cada bacia hidrográfica, responsável pela coordenação e planejamento de ações em cada bacia;

\section{Lições da Experiência Internacional}

5. Importância da participação pública no processo de planejamento e tomada de decisões, em todos os níveis de gestão, englobando todos os atores envolvidos;

6. Necessidade de capacitação dos profissionais envolvidos com gestão de recursos hídricos;

7. Sensibilização e conscientização públicas baseadas em programas efetivos de informação, transparência e comunicação de todos os envolvidos; 


\section{Lições da Experiência Internacional}

8. Estabelecimento de instrumentos técnicos, regulatórios, econômicos, de disciplinamento e penalização;

9. Importância da elaboração de um planejamento a curto, médio e longo prazos na bacia; e

10. Equilíbrio orçamentário anual e autonomia financira em cada bacia hidrográfica, seguindo os princípios de utilizador-pagador $\mathrm{e}$ poluidor-pagador.

\section{Atual sistema de gestão de recursos hídricos no Brasil}

Criação e funcionamento de 170 comitês de bacia no país

- Comitês de Bacia de rios de domínio federal (Res. CNRH n ${ }^{\circ} 5 / 00$ ):

- Representantes do poder público-União, Estados e Distrito

Federal, e Municípios $\rightarrow$ limite máximo: $40 \%$ dos votos

- Usuários das águas $\rightarrow$ limite máximo: $40 \%$ dos votos

- Entidades civis de recursos hídricos $\rightarrow$ limite mínimo:20\%

- Comitês de Bacia de rios de domínio estadual - tripartite e paritária:

Representantes do Estado

Representantes dos Municipios

Entidades civis de recursos hidricos - Sociedade Civil 


\section{Desafios do atual sistema de gestão de recursos hídricos no Brasil}

- Adoção da bacia hidrográfica como unidade de gestão

- Participação pública no planejamento e na tomada de decisão

- Representatividade das entidades

- Representatividade dos representantes

- Capacitação técnica em recursos hídricos

- Sensibilização, informação e comunicação

- Planos de Bacia

- Recursos financeiros $\rightarrow$ FEHIDRO e Cobrança

\section{Estudo de Caso}

10 Lições da

Experiência Internacional

Desafios do atual sistema de gestão no Brasil
Questionário sobre Gestão de Recursos Hídricos

segundo Categorias de Análise 


\section{A bacia escolhida: Tietê - Jacaré}

.34 municipios

• 1,48 milhões de habitantes

- Implantação do CBH TJ em 1995

- Sede da Secretaria Executiva: Araraquara

- Rios de dominialidade estadual, apenas

- Facilidade para aplicar constatações a outros comitês

\section{Bacia Hidrográfica do Tietê - Jacaré}

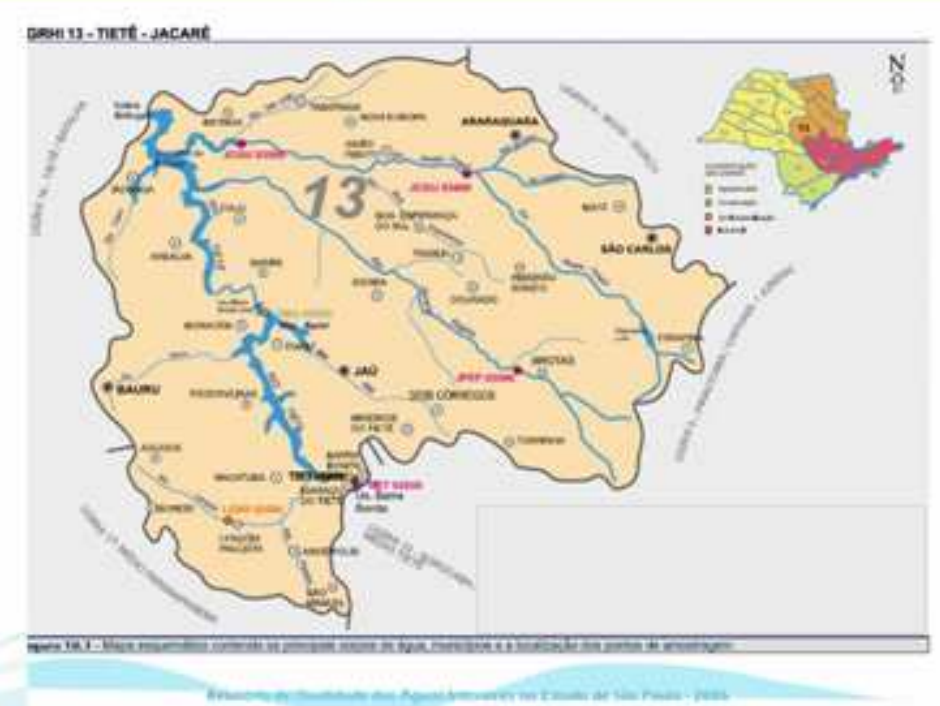




\section{Composição do CBH Tietê - Jacaré}

36 representantes -12 de cada setor

- Municípios: Prefeitos nas vagas de titular e de suplente

- Estado: Representantes de secretarias ou instituições estaduais

- Sociedade Civil:

- 1 vaga para associações de usuários urbanos

1 vaga para associações de usuários rurais

- 1 vaga para associações de usuários industriais

3 vagas para universidades

1 vaga para institutos de pesquisa

1 vaga para entidades ambientalistas

1 vaga para entidades de recuperação florestal

1 vaga para associações de classes e sindicatos

1 vaga para associações técnicas

1 vaga para associações de esportes, turismo, lazer e navegação

\section{Resultados do Estudo de Caso}

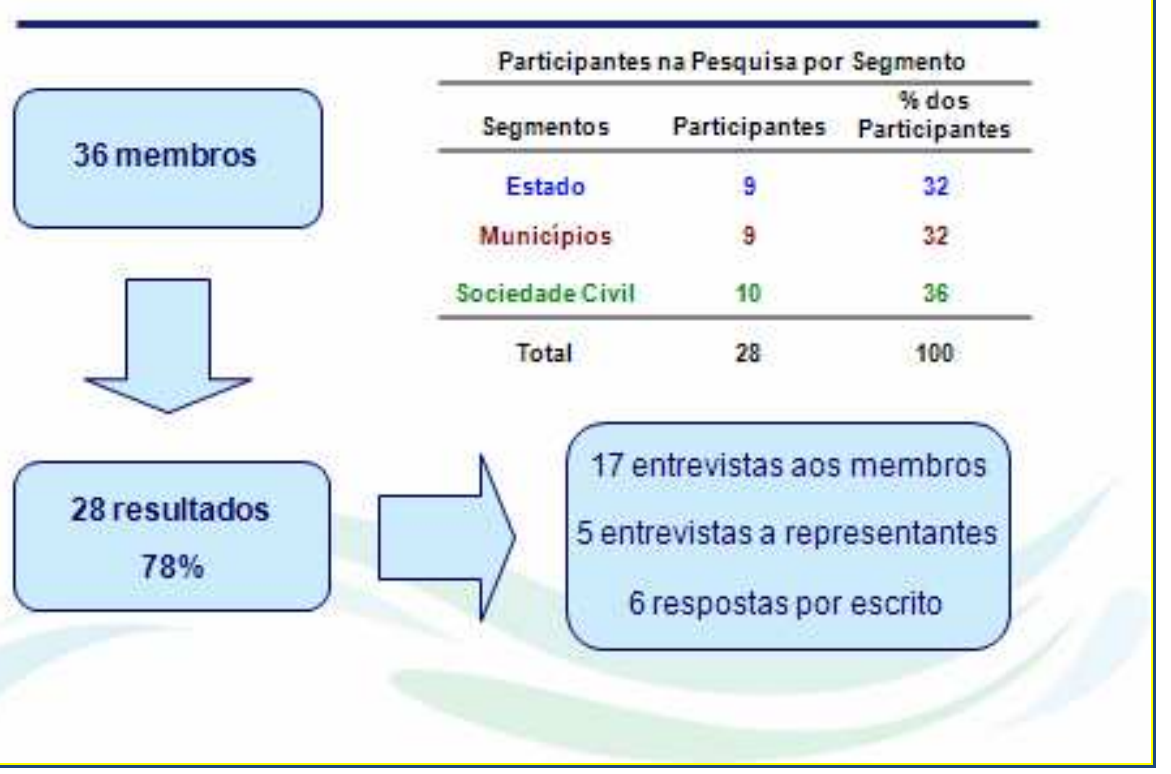




\section{Participação dos Envolvidos}

\begin{tabular}{|c|c|}
\hline $\begin{array}{c}\text { Aspecto a ser } \\
\text { analisado }\end{array}$ & Perguntas feitas nas entrevistas \\
\hline \multirow{3}{*}{$\begin{array}{l}\text { Condiçŏes de } \\
\text { Participaçăo dos } \\
\text { Membros no Comitê }\end{array}$} & $\begin{array}{c}\text { 2.11 Vocề recebe alguma ajuda financeira para comparecer } \\
\text { às reunióes? Especificar quais: transporte, alimentaçăo, } \\
\text { diária. }\end{array}$ \\
\hline & $\begin{array}{l}\text { 2.12 Você está satisfeito com suas condiçóes de } \\
\text { participaçắo no comitê? }\end{array}$ \\
\hline & $\begin{array}{c}\text { 2.15 Você vê algum problema na participaçào de algum } \\
\text { segmento especifico na gestăo da bacia? Citar o tipo de } \\
\text { problema. }\end{array}$ \\
\hline $\begin{array}{l}\text { Composiçăo dos } \\
\text { Comites }\end{array}$ & $\begin{array}{l}\text { 2.16 Você vê algum problema na composiçăo do comitê, } \\
\text { quanto ao número de vagas elou quanto às entidades } \\
\text { participantes? }\end{array}$ \\
\hline
\end{tabular}

\section{Condições de Participação}

- Apenas 2 membros não recebem ajuda financeira para reuniốes, porém há alguns problemas de logística:

- Ausência às reuniões, em especial por problemas de agenda ou outros motivos particulares, mas também por baixo comprometimento;

- Dificuldade da Sociedade Civil para comparecer às reuniões por conta própria, por ser em horário de trabalho;

- Vinculação da presença dos membros aos assuntos da pauta, em especial dos prefeitos;

- Ausência de participação efetiva, mesmo se presente nas reuniões. 


\section{Composição do Comitê Tietê - Jacaré}

- Representação do segmento Municípios:

- obrigatoriedade de serfeita por prefeitos, inclusive na suplência

- Necessidade de revisão das vagas da Sociedade Civil devido a:

- ausência de representação de moradores de baixa renda, sociedades de bairros ou excluídos;

- mais vagas para ONGs e para a agroindústria;

- questionamento da participação de associações como Sociedade Civil;

- questionamento das 3 vagas para universidades.

\section{Composição dos Comitês Estaduais}

- Questỗes provocadas pela divergência da legislação estadual e federal:

, composição tripartite, onde Estado e Município são considerados

separados, e não unidos como poder público;

. ausência de instituições federais;

. ausência do segmento dos usuários em separado.

- Diferenças entre limites das UGRHIs e :

- limites administrativos municipais

- limites das regionais das entidades estaduais. 

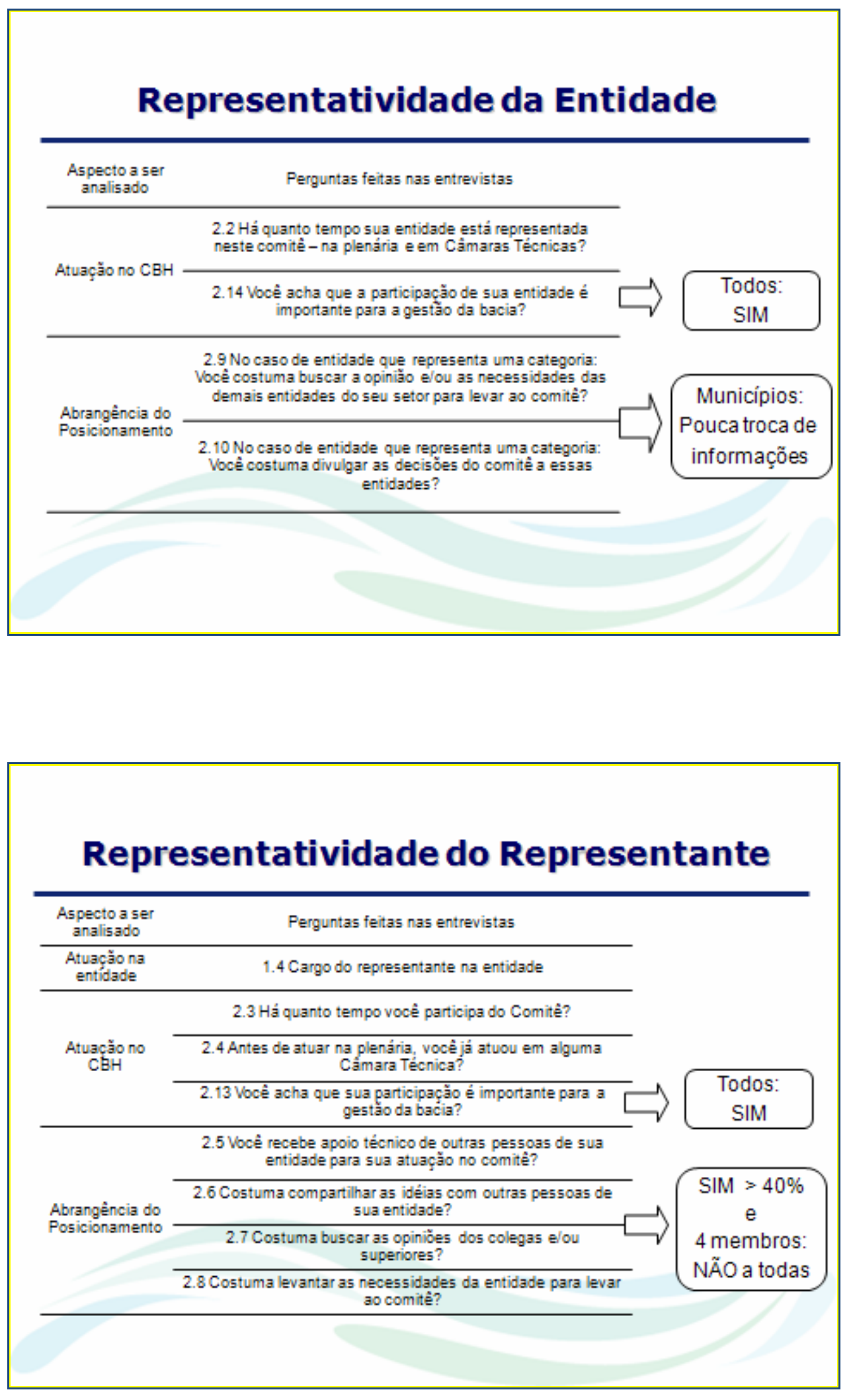


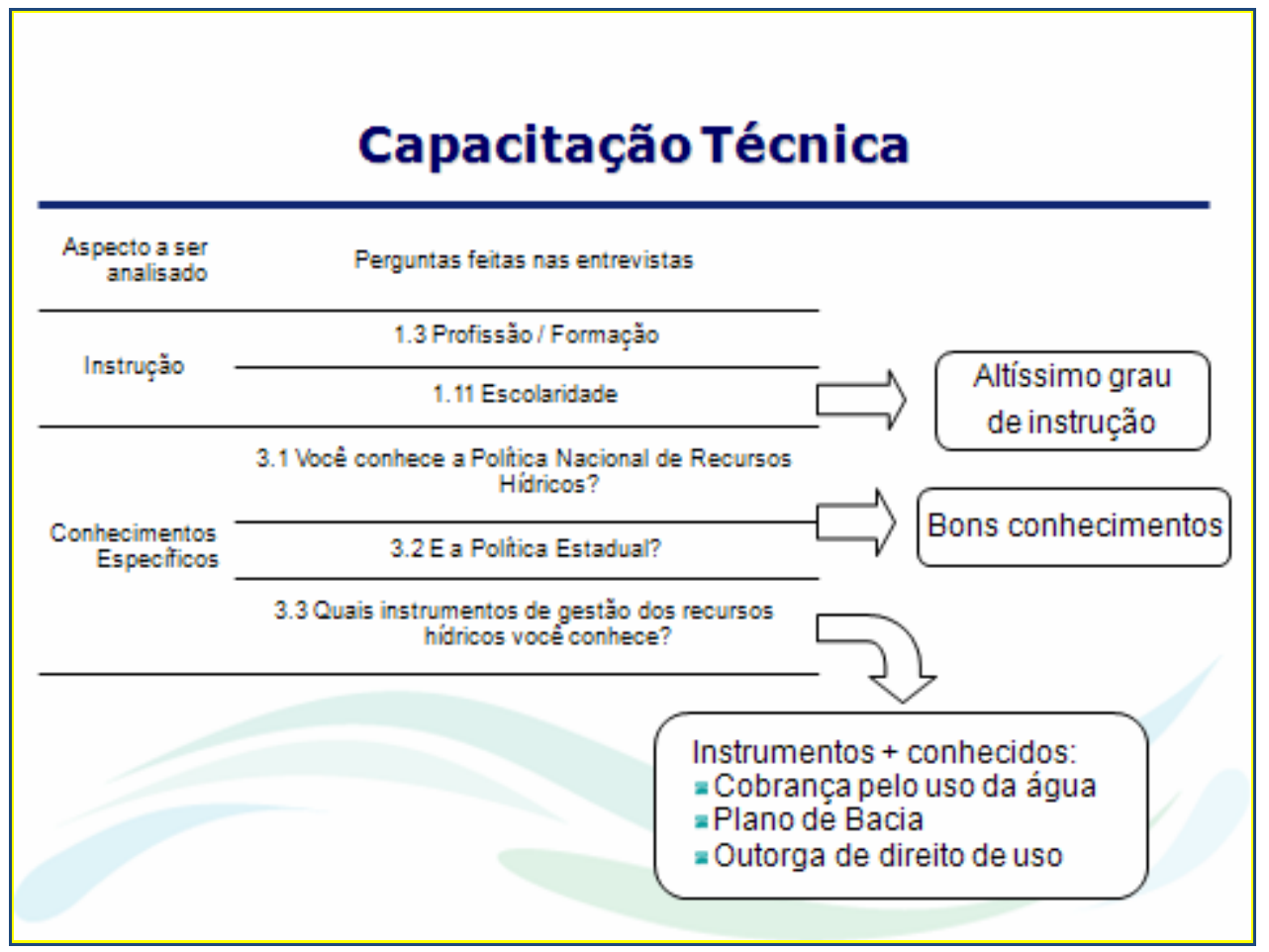

\section{Informação e Comunicação}

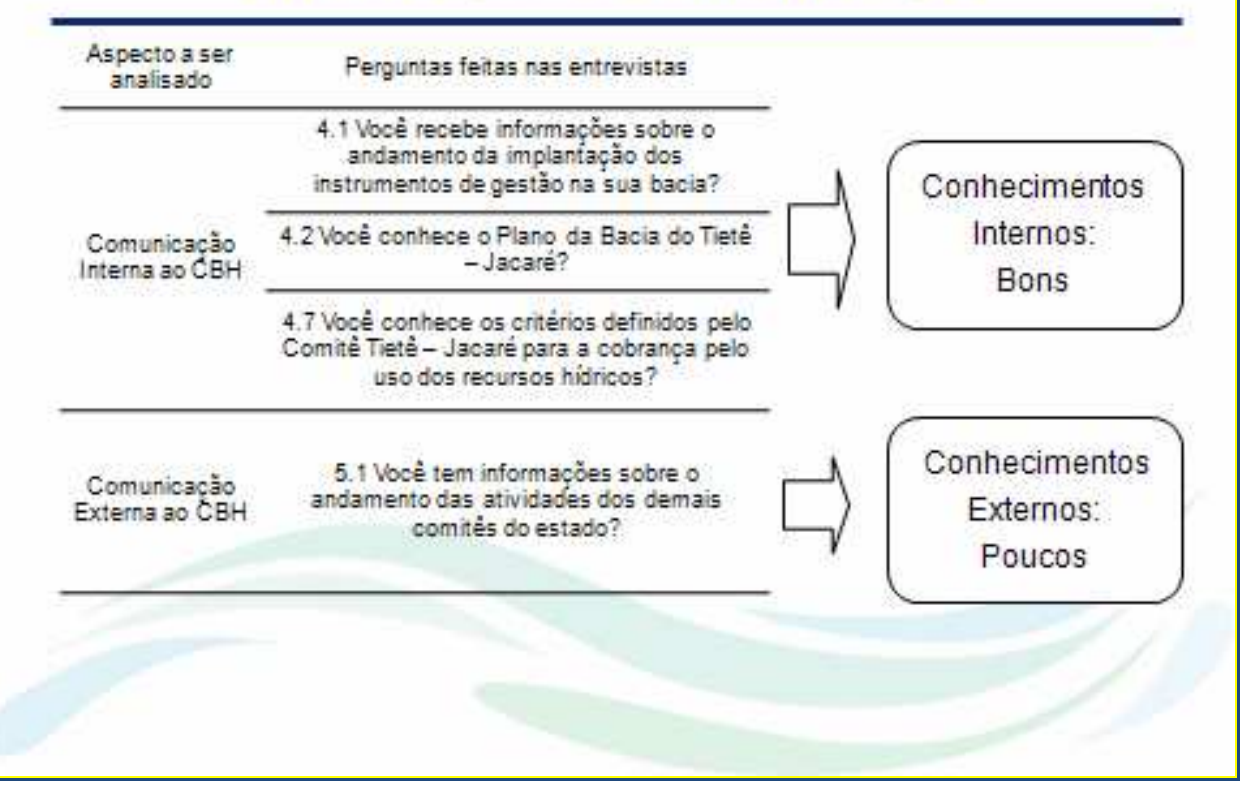




\section{Plano de Bacia}

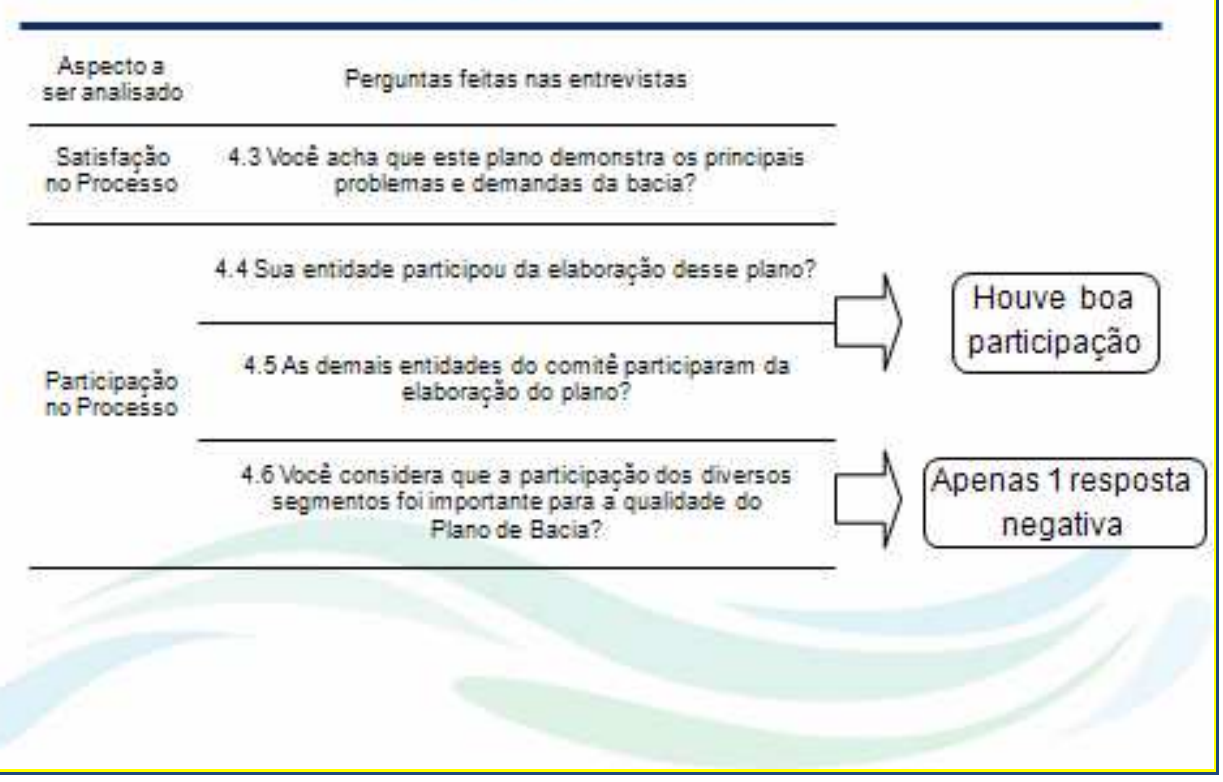

\section{Cobrança pelo Uso da Água}

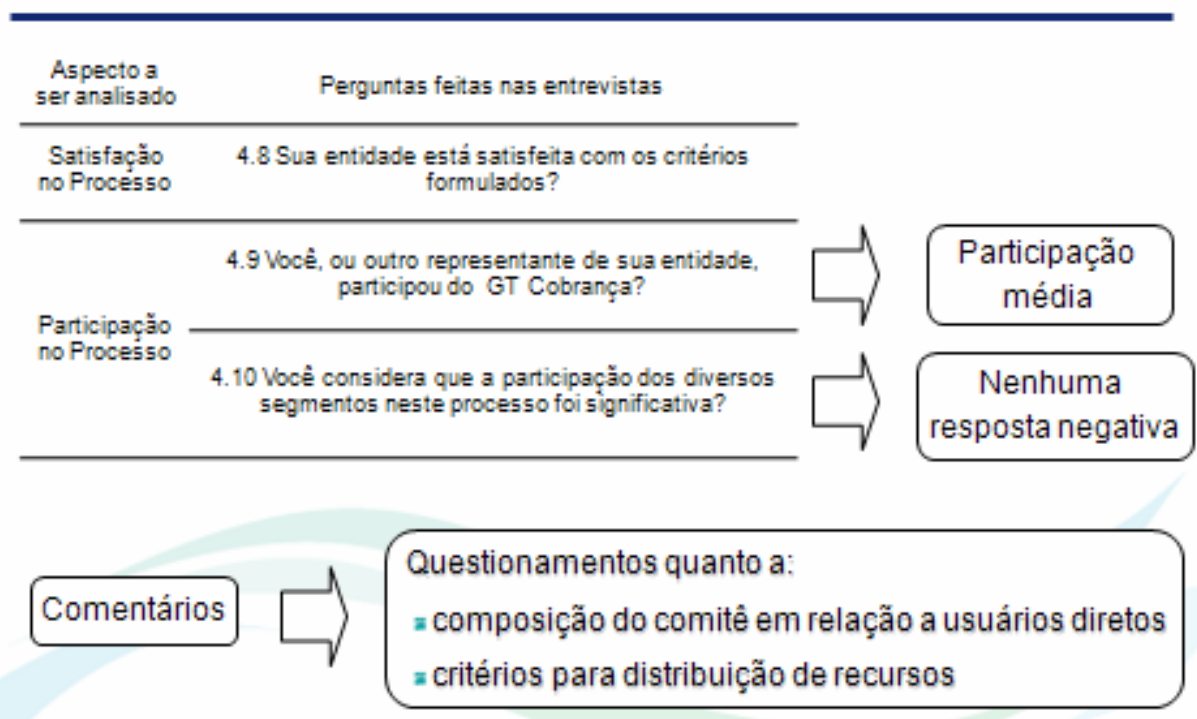




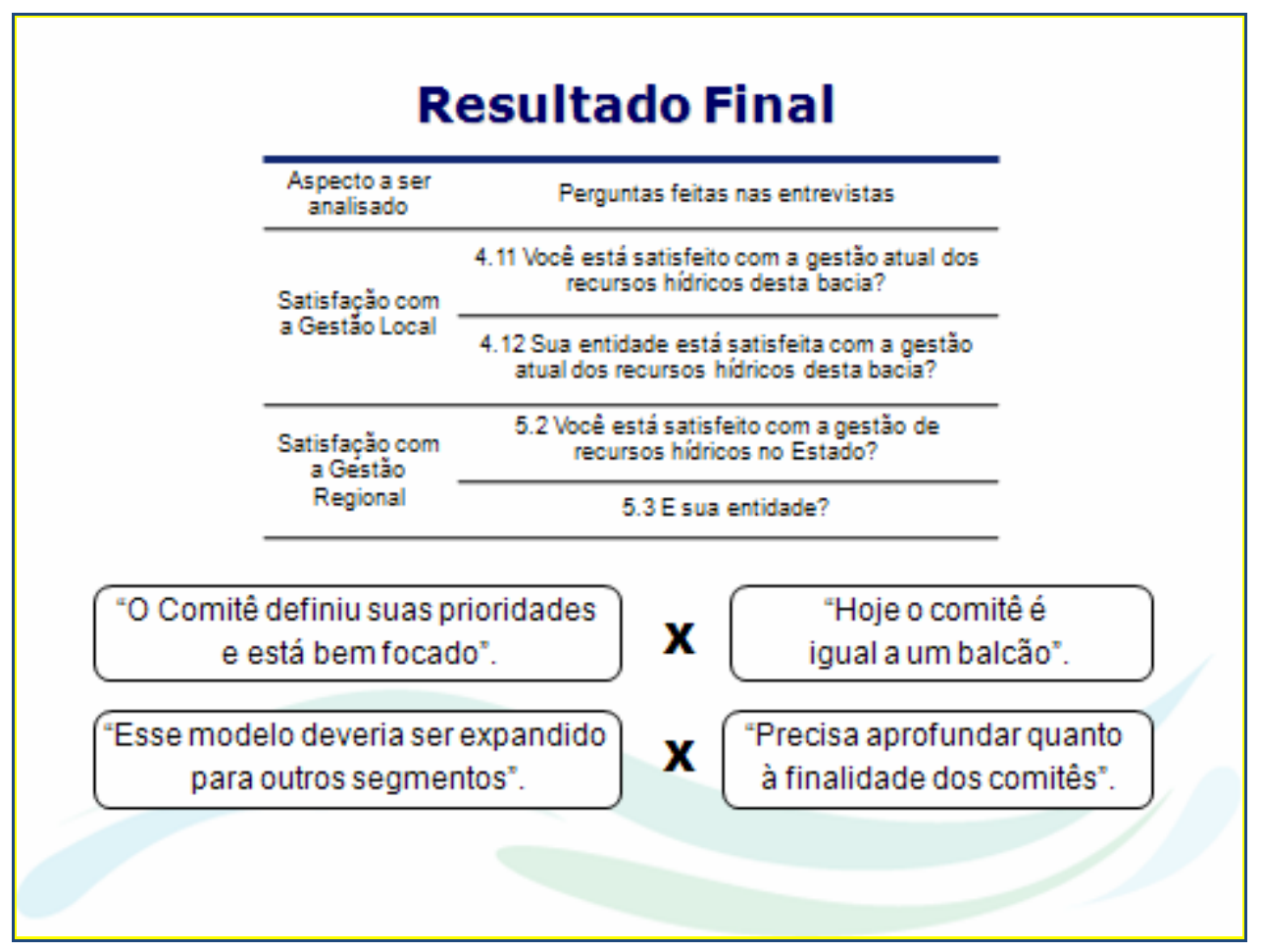

\section{Conclusões}

Aspectos afetos à competência do Comitê:

- Descontentamento em relação ao número excessivo de faltas

- Problemas para garantir condições de participação a todos

- Composição atual não garante espaço a todos os envolvidos

- Reconhecimento da importância do comitê por todos os membros

- Boa divulgação das informações no âmbito do Comitê

- Definição dos critérios da cobrança: "trabalho fantástico"

Aspectos afetos à competência do Estado:

- Divisão das UGRHIs não segue limites das bacias hidrográficas e não

é adotada pelos órgãos de governo

- Divergências entre legislações federal e estadual quanto à composição

- Pouca divulgação das questões de recursos hídricos do Estado 


\section{Recomendações Finais}

Aspectos afetos à competência do Comitê:

- Revisão do estatuto do comitê visando:

. Estudar a viabilidade de ajuda de custo à Sociedade Civil

- Avaliar a composição atual da Sociedade Civil no comitê

- Avaliar a obrigatoriedade de representação pelos prefeitos

- Instituir regras para perda de vagas após limite de faltas

- Criação de site próprio e de banco de dados

- Revisão dos critérios para distribuição de recursos para projetos

Aspectos afetos à competência do Estado:

- Avaliação da Lei Estadual n 7663/91 frente à Lei Federal n 9433/97:

- Composição dos segmentos

- Categoria Usuários

- Divulgação das responsabilidades dos comitês e sua importância - Avaliação das divergências dos limites das UGRHIs e das áreas de atuação das regionais das secretarias de estado.

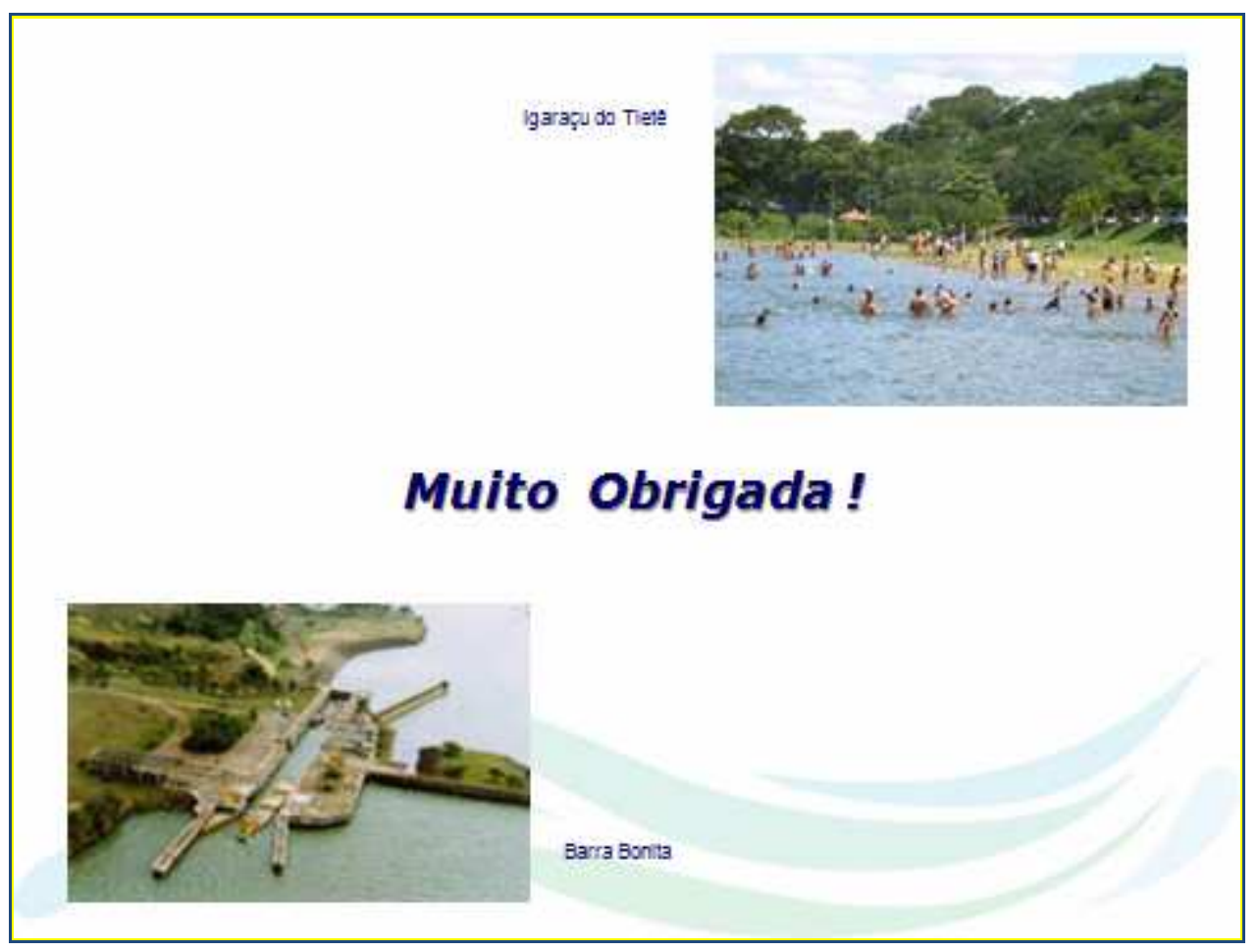

